UNIVERSIDADE DE SÃO PAULO

INSTITUTO DE GEOCIÊNCIAS

RESÍDUOS DE MINERAÇÃO E METALURGIA:

EFEITOS POLUIDORES EM SEDIMENTOS E EM ESPÉCIE BIOMONITORA RIO RIBEIRA DE IGUAPE - SP

\author{
Valéria Guimarães \\ Orientador: Prof. Dr. Joel Barbujiani Sígolo
}

TESE DE DOUTORADO

Programa de Pós-Graduação em Geoquímica e Geotectônica

SÃO PAULO

2007 
Ficha catalográfica preparada pelo Serviço de Biblioteca e Documentação do Instituto de Geociências da Universidade de São Paulo

Guimarães, Valéria

Resíduos de mineração e metalurgia: efeitos poluidores em sedimentos e em espécie biomonitora Rio Ribeira de Iguape-SP / Valéria Guimarães. São Paulo, 2007.

160 f. : il.

Tese (Doutorado) : IGc/USP

orient.: Sígolo, Joel Barbujiani

1. Resíduos sólidos 2. Metais 3. Ribeira de Iguape(SP). Poluição de rios I. Título 
Ao meu amado e eterno pai Élcio "in memorian" e ao meu querido irmão Marcelo "in memorian", que são exemplos de honestidade, força, dedicação e amor.

Dedico não apenas esta tese, como também, o meu amor e admiração a estas duas pessoas que contribuíram muito na minha caminhada, tanto profissional como pessoal. 
Gostaria de agradecer a Deus acima de tudo, por me dar coragem no momento mais difícil desta jornada, permitindo que eu finalizasse esta pesquisa.

Ao Prof. Dr. Joel B. Sígolo, pela orientação, dedicação, confiança, paciência e amizade, proporcionados durante estes dez anos de convivio, o qual sou eternamente grata. Nos momentos mais dificeis demonstrou uma amizade sincera e muita compreensão.

À Fundação de Amparo a Pesquisa do Estado de São Paulo (FAPESP - Processo 02/09726-0), pela concessão da bolsa de estudo.

Aos membros da banca do exame de qualificação: Prof. Dr. Moysés Gonçales Tessler do Instituto Oceanográfico (IO) e Prof. Dr. Raphael Hypolito do Instituto de Geociências (IGc), ambos da Universidade de São Paulo (USP), pelas sugestões fornecidas.

Ao Prof. Dr. Wagner Avelar e à Dr ${ }^{a}$. Andréa Cristina Tomazelli, ambos da faculdade de Filosofia, Ciências e Letras de Ribeirão Preto da USP, pelo auxílio na identificação e classificação dos bivalves utilizados nesta pesquisa.

À Prof. Dra. Maria Fernanda Giné Rosías do Laboratório de Química Analítica do CENA, pela ajuda e execução das análises químicas. Ao Prof. Dr. Osny Bacchi do Laboratório de Física do Solo do CENA, pela execução das análises granulométricas.

Aos técnicos do Laboratório de Química e Fluorescência de Raios X do IGc-USP, que executaram todas as análises químicas com grande competência e eficiência. Gostaria de agradecer à Sandra por ter me auxiliado na parte de química analítica.

Ao pessoal da Central Analítica do IQ-USP e aos técnicos do LCT da Faculdade de Engenharia de Minas-USP, que executaram parte das análises químicas.

À técnica e amiga do Laboratório de Sedimentologia do IGc-USP, Elaine, que realizou parte das análises granulométricas.

Ao Issac do Laboratório de Microscopia Eletrônica de Varredura (MEV) do IGc-USP, pela realização das análises microscópicas e ao Flávio do Laboratório de Difração de Raios X (DRX) do IGc-USP, pela realização das análises de difração.

Aos funcionários Ana Paula (Secretária da Pós-Graduação), Magali (Secretária da Pós-Graduação), Tadeu (Secretário da Pós-Graduação), Verônica (Laboratório de Geoquímica), Érica (Biblioteca), Brenda (Biblioteca), Samuel (Preparação de Amostras) e José Carlos (Áudio-Visual), pela paciência e ajuda prestada.

À Seção Gráfica e à Seção de Reprodução Fotográfica, que sempre foram atenciosos.

Ao Programa de Pós-Graduação em Geoquímica e Geotectônica e ao Departamento de Geologia Sedimentar e Ambiental (DGSA) do IGc-USP.

Aos amigos da pós-graduação e graduação do IGc-USP, em especial à Lucelene (Wal), Cyntia, José Guilherme, Sibele, Cely, Rosely, Mika, George e Daniela, pela amizade e apoio.

Aos meus familiares (mãe, sogra, irmã, cunhados e sobrinhos) pelo apoio e amor incondicionais, principalmente ao meu marido "Elmar" por toda dedicação, carinho, apoio, paciência, ajuda e compreensão. Gostaria de agradecer também a uma pessoa que é sinônimo de coragem e força, minha cunhada Ana, pelo apoio, incentivo e orientação.

À minha tia Sinhá, pelo apoio e compreensão fornecidos para que eu pudesse terminar a minha graduação e meu mestrado, sem ela não poderia ter realizado esta tese.

Ao meu sogro Doracir "in memorian", pelo carinho e amizade.

A todos que direta ou indiretamente contribuíram para a realização deste trabalho. 
GUIMARÃES, V. Resíduos de mineração e metalurgia: efeitos poluentes em sedimentos e em espécie biomonitora - Rio Ribeira de Iguape - SP. 2007. p. 160. Tese (Doutorado) - Instituto de Geociências, Universidade de São Paulo, São Paulo.

Por aproximadamente 40 anos, o Rio Ribeira de Iguape recebeu resíduos da mineração: rejeitos das plantas de concentração mineral (enriquecidos em $\mathrm{Cu}, \mathrm{Cr}, \mathrm{Pb}, \mathrm{Ag}$ e $\mathrm{Zn}$ ) e escórias de uma unidade de metalurgia (enriquecidas em $\mathrm{Cu}, \mathrm{Zn}, \mathrm{Cr}, \mathrm{Fe}, \mathrm{Pb}$ e $\mathrm{As}$ ), produzidos e descartados pela empresa Plumbum S/A, localizada em Adrianópolis (Paraná). Para verificar a contribuição destes resíduos na contaminação deste rio, como também identificar a possibilidade de depuração natural ou não no mesmo, definiu-se a necessidade de avaliar três compartimentos: resíduos, sedimentos e organismo biomonitor. Nas amostras de resíduos foram realizadas caracterizações físicas e químicas, nos sedimentos foram realizadas análises químicas, granulométricas e algumas amostras investigadas por MEV/EDS e no biomonitor (molusco Asiático da espécie Corbicula fluminea) foram realizadas análises químicas dos tecidos e das carapaças. Estas análises indicaram a existência de elevados teores de $\mathrm{Pb}$ nos resíduos da mineração, os quais ultrapassaram os valores deste metal estabelecidos na norma NBR 10.005 da ABNT. Nesta comparação, os rejeitos do concentrado da Mina do Rocha ultrapassaram em 32 vezes, os da Plumbum em 41 vezes e as escórias em 34 vezes, os limites estabelecidos por tal norma, sendo assim classificados como pertencentes à Classe I - perigosos. Destes resíduos o mais problemático atualmente é o rejeito da Plumbum, por apresentar granulometria fina, $\mathrm{pH}$ mais baixo, apresentar maior teor de $\mathrm{Pb}$ no teste de lixiviação, além de estar depositado muito próximo de uma das margens do Rio Ribeira de Iguape. A interação destes resíduos com o sistema aquático foi verificada a partir da detecção de $\mathrm{Pb}, \mathrm{Zn}, \mathrm{Cu}$ nos sedimentos. Os sedimentos depositados em bancos de areia e os estuarinos exibiram maiores teores para $\mathrm{Pb}$ (média de 135,00 mg/ $\mathrm{kg}$ para os depósitos em bancos de areia e 124,00 mg/ $\mathrm{kg}$ para os estuarinos) e Zn (média de $112,62 \mathrm{mg} / \mathrm{kg}$ para os depositados em bancos de areia e de 133,00 mg/kg para os estuarinos). Em todos os tipos de sedimentos foi constatado que o local de coleta que exibiu teores mais elevados para os metais de estudo foi em Iporanga, secundariamente na Ilha do Caranguejo na região do Mar Pequeno, a sul de Iguape. Nos sedimentos em suspensão, as análises em MEV/EDS exibiram a presença de grãos de escória, indicando que estes ainda hoje, estão interagindo com este ambiente e sendo transportados. Esta comprovação, só foi possível, de fato, a partir das análises de tecidos e de carapaças da espécie Corbicula fluminea, os quais demonstraram estar havendo interação dos metais pesados provenientes dos resíduos com a biota deste sistema aquático. Nos tecidos deste biomonitor foram detectados em média 23,99 $\mu \mathrm{g} / \mathrm{g}$ de $\mathrm{Cu}, 144,21 \mu \mathrm{g} / \mathrm{g}$ de $\mathrm{Zn}, 0,71 \mu \mathrm{g} / \mathrm{g}$ de $\mathrm{Cd}, 2,41 \mu \mathrm{g} / \mathrm{g}$ de $\mathrm{Pb}$ e 7,11 $\mu \mathrm{g} / \mathrm{g}$ de $\mathrm{Cr}$. Destes metais, o mais preocupante é o $\mathrm{Pb}$, ele apresenta concentrações mais elevadas que os relatados em outros estudos para este mesmo bivalve e também, ultrapassa o valor de referência da ANVISA $(2,00 \mu \mathrm{g} / \mathrm{g})$ para a concentração deste metal pesado em peixes e produtos de pesca para consumo. Além dos tecidos, as carapaças deste biomonitor, também estão concentrado estes metais pesados. De modo geral, concluiu-se que o Rio Ribeira não está sofrendo processos naturais de depuração e que ainda hoje representa um problema ambiental, pois os metais estão migrando ao longo do curso da drenagem e neste processo sendo biodisponibilizados, o que pode vir a gerar transferência e acumulação na cadeia trófica.

Palavras-Chave: Metais pesados, resíduos, sedimentos e biomonitores. 
GUIMARÃES, V. Resíduos de mineração e metalurgia: efeitos poluentes em sedimentos e em espécie biomonitora - Rio Ribeira de Iguape - SP. 2007. p. 160. Tese (Doutorado) - Instituto de Geociências, Universidade de São Paulo, São Paulo.

Residues of mining and metallurgy: pollutant effect in sediments and biomonitor species - River Ribeira de Iguape

For approximately 40 years, Ribeira de Iguape River received mining wastes (enriched in $\mathrm{Cu}$, $\mathrm{Cr}, \mathrm{Pb}, \mathrm{Ag}$ and $\mathrm{Zn}$ ) and metallurgical slags (enriched in $\mathrm{Cu}, \mathrm{Zn}, \mathrm{Cr}, \mathrm{Fe}, \mathrm{Pb}$ and $\mathrm{As}$ ), produced and discharged by Plumbum S/A, a company located in Adrianópolis (Paraná). In order to verify the contribution of these residues in the river contamination and natural purification the compartments of mining residues, sediments and bioindicator organisms were evaluated. Physical and chemical characterizations were realized in the residues samples; while chemical analyses, grain size evaluation and MEV/EDS were carried out in sediments. Asiatic clam (Corbicula fluminea) was taken as a bioindicator, through chemical analyses of its tissues and shells. The results showed high Pb levels, being classified as Class 1 - dangerous - by ABNT, norm NBR 10,005, once the limited levels were exceeded by Rocha wastes (32x), Plumbum wastes (41x) and slags $(34 \mathrm{x})$. The Plumbum waste is currently the most problematic, as it is made of fine grain, lower $\mathrm{pH}$, higher $\mathrm{Pb}$ level detected in the extraction test and is deposited very close to the draining site. The interactions of these residues with the aquatic system was verified through $\mathrm{Pb}, \mathrm{Zn}, \mathrm{Cu}$ detection in the sediments. $\mathrm{Pb}$ and $\mathrm{Zn}$ levels were, respectively, $135.00 \mathrm{mg} / \mathrm{kg}$ and $112.62 \mathrm{mg} / \mathrm{kg}$ in the sand banks deposits, and $124.00 \mathrm{mg} / \mathrm{kg}$ and $133.00 \mathrm{mg} / \mathrm{kg}$ in the estuaries deposits, with prominent metal levels in Iporanga and, secondary, in Crab Island, region of the Small Sea, south of Iguape. MEV/EDS analyses carried out in suspended sediments showed the presence of slags grains, suggesting that still nowadays they are transported and interact with the environment, once they have been detected in tissues and shells samples of Corbicula fluminea. In the tissues of this bioindicator, there were detected average levels of $23.99 \mu \mathrm{g} / \mathrm{g}$ of $\mathrm{Cu}, 144.21 \mu \mathrm{g} / \mathrm{g}$ of $\mathrm{Zn}, 0.71$ $\mu \mathrm{g} / \mathrm{g}$ of $\mathrm{Cd}, 7.11 \mu \mathrm{g} / \mathrm{g}$ of $\mathrm{Cr}$ and $2.41 \mu \mathrm{g} / \mathrm{g}$ of $\mathrm{Pb}$; making evident that this last value is strongly high and over the ANVISA reference $(2.00 \mu \mathrm{g} / \mathrm{g})$ for fish and other consumption products. The results suggest that natural processes of Ribeira de Iguape River are not sufficient for its purification, keeping metals' transport and bioavailability, which can accumulate in the trophic chain, representing a serious environmental problem.

Key-words: Heavy metals, wastes, sediments and bioindicator. 


\section{LISTA DE FIGURAS}

Figura 1 - Mapa de localização e principais vias de acesso da área de estudo___ 17

Figura 2 - Perfil longitudinal do Rio Ribeira de Iguape __ 28

Figura 3 - Moluscos bivalves da espécie Corbicula fluminea ___ 43

Figura 4 - Mapa de localização das minas do alto Vale do Ribeira-rejeitos do concentrado da mina do Rocha e da Plumbum 47

Figura 5 - Pilha de rejeito do concentrado da mina do Rocha 48

Figura 6 - Rejeito da mina do Rocha depositado às margens do ribeirão homônimo 48

Figura 7 - Rejeitos do concentrado da Plumbum depositados na área da mina de Panelas __ 50

Figura 8 - Planta esquemática do depósito de rejeitos do concentrado da Plumbum _ 51

Figura 9 - Pilha de escória depositada na área da mina de Panelas pela empresa Plumbum__ 53

Figura 10 - Mapa de localização dos pontos de amostragem, com detalhes das variações granulométricas dos sedimentos depositados em bancos de areia.

Figura 11 - Mapa de localização dos pontos de amostragem dos sedimentos em bancos de areia, com detalhes de alguns pontos de coleta que apresentaram particularidades na área deposicional.

Figura 12 - Materiais empregados na coleta do perfil de sedimento depositado em banco de areia 58

Figura 13 - Mapa de localização dos pontos de coleta dos sedimentos ativos de corrente 59

Figura 14 - Mapa de localização dos sedimentos em suspensão 61

Figura 15 - Coleta do sedimento em suspensão em tanque de decantação. 62

Figura 16 - Localização do ponto de coleta do sedimento estuarino 64

Figura 17 - Amostragem do perfil de sedimento estuarino 65

Figura 18 - Espécie de biomonitor - Corbicula fluminea 66

Figura 19 - Tecidos liofilizados dos bivalves (Corbiculas flunineas) 66

Figura 20 - Espectro EDS da amostra de rejeito do concentrado da Mina do Rocha 75

Figura 21 - Espectro EDS da amostra de rejeito do concentrado da Mina do Rocha 75

Figura 22 - Concreção detectada nos rejeitos da Plumbum. (Imagem com elétron retro-espalhado) 82

Figura 23 - Espectro EDS da área A da Figura 22 82

Figura 24 - Espectro EDS da área B da Figura 22 82

Figura 25 - Espectro EDS do ponto A da Figura 26 (cristal secundário) 83

Figura 26 - Imagem com recurso split (obtida por elétrons retroespalhados à esquerda e por secundários à direita), nota-se cristais secundários precipitados sobre a superfície do fragmento carbonático 83

Figura 27 - Mineral lamelar encontrado na pilha de rejeito da Pumblum 84

Figura 28 - Espectro EDS obtido no ponto A da figura 27

Figura 29 - EDS representativos da composição do rejeito da Plumbum 84

Figura 30 - EDS representativos da composição do rejeito do concentrado da Plumbum 85

Figura 31 - Imagem com elétrons retro-espalhados em MEV da escória 90

Figura 32 - Espectro EDS representativos da composição da escória 90

Figura 33 - Depósito em banco de areia-amostragem de 3,0 m de profundidade 101

Figura 34 - Esfera de Fe detectada na parte magnética do sedimento em suspensão (imagem com elétrons retroespalhados em MEV) 
Figura 35 - Estrutura detectada na parte magnética do sedimento em suspensão com várias esferas de Fe (seta vermelha) em seu interior (imagem com elétrons retro-espalhados obtida em MEV)

Figura 36 - Cristal de magnetita detectado na porção magnética do sedimento em suspensão (imagem com elétrons retro-espalhados obtida em MEV)

Figura 37 - Grão de argilo-mineral (parte escura da imagem) juntamente com hidróxido de Fe (parte brilhante da imagem). Imagem em MEV com elétrons retro-espalhados 123

Figura 38 - EDS (representativo) de alguns grãos que compõem a parte magnética do sedimento em suspensão

Diagrama Triangular 1 - Variação granulométrica das amostras de rejeito do concentrado da Mina do Rocha, obtidas em sondagem de $3,40 \mathrm{~m}$ 69 


\section{LISTA DE TABELAS E QUADROS}

Tabela 1 - Distribuição granulométrica das amostras de rejeito do concentrado da Mina do Rocha (\%).......... 68

Tabela 2 - Mineralogia da fração areia - amostras de rejeito da Mina do Rocha - \%...................................... 69

Tabela 3 - Quantificação aproximada dos argilominerais da fração argila - rejeitos da Mina do Rocha (\%).... 70

Tabela 4 - Quantificação de dolomita e cerussita na fração silte - rejeitos Mina do Rocha - \% ......................... 70

Tabela 5 - Análise química total das amostras de rejeito da Mina do Rocha - FRX - \% de óxidos .................... 71

Tabela 6 - Teores de metais pesados detectados no rejeito da mina do Rocha, convertidos para mg/kg............ 72

Tabela 7 - Matriz de correlação de Pearson para os elementos detectados no rejeito da Mina do Rocha ......... 74

Tabela 8 - Distribuição granulométrica das amostras de rejeito do concentrado da Plumbum (\%) ................... 77

Tabela 9 - Distribuição granulométrica da fração areia - rejeito do concentrado da Plumbum (\%).................. 77

Tabela 10 - Análise química total das amostras de rejeito da Plumbum - FRX - \% de óxidos ........................... 78

Tabela 11 - Teores de metais pesados e do Ba detectados no rejeito da Plumbum $(\mathrm{mg} / \mathrm{kg})$.............................. 78

Tabela 12 - Matriz de correlação de Pearson para os elementos detectados no rejeito da Plumbum ..................81

Tabela 13 - Análise química total das amostras de escória - FRX - \% de óxidos .............................................89

Tabela 14 - Teores de metais pesados e do Ba detectados na escória $(\mathrm{mg} / \mathrm{kg})$................................................ 89

Tabela 15 - Matriz de Correlação de Pearson para as frações granulométricas e os elementos detectados nos sedimentos depositados em bancos de areia

Tabela 16 - Análise química total dos sedimentos coletados em perfil 3 m de profundidade a 14 km de Iporanga

Tabela 17 - Metais pesados e Ba detectados nos sedimentos ativos de corrente: Digestão Total (ataque com ácido fluorídrico) e Extração Parcial (ataque com água régia). Análise em ICP/OES

Tabela 18 - Elementos maiores detectados nos sedimentos ativos de corrente: Digestão Total (ataque com ácido fluorídrico) e Extração Parcial (ataque com água régia). Análise em ICP/OE

Tabela 19 - Análise química total por FRX - sedimento em suspensão - \% de óxidos. 114

Tabela 20 - Teores de Ba e metais pesados nos sedimentos em suspensão ( $\mathrm{mg} / \mathrm{kg})$ 115

Tabela 21 - Matriz de Correlação de Pearson para os parâmetros físico-químicos e elementos químicos nos sedimentos em suspensão

Tabela 22 - Comparação dos teores detectados na porção magnética e não magnética do sedimento em suspensão, coletado em Eldoardo - FRX - \% de Óxidos

Tabela 23 - Teores de metais pesados em $\mathrm{mg} / \mathrm{kg}$ nas porções magnéticas e não magnéticas do sedimento em suspensão de Eldorado, comparados com valores de referência PEL/TEL do CCME (1999)

Tabela 24 - Análise química total por FRX do sedimento estuarino - amostragem de 0,45m - \% de óxidos..... 126 Tabela 25 - Matriz de Correlação de Pearson para as frações granulométricas, profundidade, matéria orgânica e elementos químicos nos sedimentos estuarinos.

Tabela 26 - Teores de metais pesados detectados na base seca dos tecidos de Corbicula fluminea - ICP/OES $\mu \mathrm{g} / \mathrm{g}$.

Tabela 27 - Teores de metais pesados detectados nas carapaças de Corbicula fluminea - ICP/AES - $\mu$ g/g...... 134 Quadro 1 - Comparação de $\mathrm{Cu}, \mathrm{Cd}, \mathrm{Pb}, \mathrm{Cr}$ e $\mathrm{Zn}$ em Corbiculas flumineas de várias localidades, em áreas não contaminadas. Intervalo de Concentração e Média \pm Desvio Padrão ( $\mu \mathrm{g} / \mathrm{g}$ em peso seco) $\mu \mathrm{g} / \mathrm{g}$. 


\section{LISTA DE GRÁFICOS}

Gráfico 1 - Média anual das chuvas em Eldorado no período histórico de 1969 a 1999 24

Gráfico 2 - Média anual das chuvas em Sete Barras no período histórico de 1969 a 1999 25

Gráfico 3 - Média anual das chuvas em Registro no período histórico de 1969 a 1999 25

Gráfico 4 - Média anual das chuvas mm (cinza) e vazões $\mathrm{m}^{3}$ /s (verde) em Eldorado no período histórico de 1969 a 1999 30

Gráfico 5 - Média anual das chuvas $\mathrm{mm}$ (cinza) e vazões $\mathrm{m}^{3} / \mathrm{s}$ (verde) em Sete Barras no período histórico de 1969 a 1999 30

Gráfico 6 - Distribuição de Ca, Mg e Si ao longo do perfil sondado no rejeito da mina do Rocha 71

Gráfico 7 - Distribuição dos teores de Pb com a profundidade - rejeito da mina do Rocha 73

Gráfico 8 - Distribuição dos teores de Cr, Cu e Zn com a profundidade - rejeito da mina do Rocha 73

Gráfico 9 - Distribuição dos teores de Pb e Zn nas diversas camadas do patamar 2 m - rejeito da Plumbum_ 79 Gráfico 10 - Distribuição dos teores de Cr e Cu nas diversas camadas do patamar 2 m - rejeito da Plumbum 80

Gráfico 11 - Distribuição do teor de Ba e S nas diversas camadas do patamar 2m - rejeito da Plumbum 80

Gráfico 12 - Distribuição granulométrica da fração areia - Escória 88

Gráfico 13 - Distribuição granulométrica das amostras de sedimentos depositados em bancos de areia 92

Gráfico 14 - Distribuição granulométrica da fração areia nos sedimentos em bancos de areia 93

Gráfico 15 - Distribuição de Ca, Mg e Fe nas amostras de 0,20 m coletadas em bancos de areia ao longo do Rio Ribeira 95

Gráfico 16 - Distribuição de Pb e Zn nas amostras de 0,20 m coletadas em bancos de areia ao longo do Rio Ribeira 97

Gráfico 17 - Distribuição de Cr e Ba nas amostras de 0,20 m coletadas em bancos de areia ao longo do Rio Ribeira

Gráfico 18 - Comparação de Cr com valores de referência PEL/TEL nos sedimentos depositados em bancos de areia

Gráfico 19 - Distribuição de Ca, Mg e Fe na sondagem de 3,0 m realizada a 14 km de Iporanga em banco de areia 103

Gráfico 20 - Comparação do Pb e Zn com valor de referência PEL/TEL na amostragem de 3,0 m em banco de areia 104

Gráfico 21 - Distribuição de Cr e Ba na sondagem de 3,0 m realizada a 14 km de Iporanga em banco de areia

Gráfico 22 - Comparação do Cr detectado na sondagem de 3,0 m com valores de referência PEL/TEL 105

Gráfico 23 - Comparação dos teores de $\mathrm{Cr}, \mathrm{Ni}, \mathrm{Cu}, \mathrm{Zn}$ e $\mathrm{Pb}$ nas análises por digestão total e por extração parcial - Sedimento de Corrente coletado em Iporanga (SAC-IP) 108

Gráfico 24 - Comparação dos teores de $\mathrm{Cr}, \mathrm{Ni}, \mathrm{Cu}, \mathrm{Zn}$ e Pb nas análises por digestão total e por extração parcial - Sedimento de Corrente coletado em Eldorado (SAC-EL)

Gráfico 25 - Comparação dos teores de $\mathrm{Cr}, \mathrm{Ni}, \mathrm{Cu}$, Zn e Pb nas análises por digestão total e por extração parcial - Sedimento de Corrente coletado em Sete Barras (SAC-SB)

Gráfico 26 - Comparação dos teores de Ba nas análises por digestão total e por extração parcial, nos sedimentos de corrente do Rio Ribeira de Iguape 
Gráfico 27 - Valores de pH obtidos nas amostras de sedimentos em suspensão 113

Gráfico 28 - Valores de Eh ( $\mathrm{mV}$ ) obtidos nas amostras de sedimentos em suspensão

Gráfico 29 - Distribuição de Ca, Mg e Fe nos sedimentos em suspensão 116

Gráfico 30 - Distribuição de Pb e Zn nos sedimentos em suspensão 117

Gráfico 31 - Distribuição de Cu e Cr nos sedimentos em suspensão 118

Gráfico 32 - Comparação entre os elementos químicos detectados na porção magnética e não magnética do sedimento em suspensão coletado em Eldorado 120

Gráfico 33 - Comparação entre os metais pesados detectados na porção magnética e não magnética do sedimento em suspensão coletado em Eldorado 121

Gráfico 34 - Distribuição granulométrica dos sedimentos estuarinos com a profundidade 125

Gráfico 35 - Distribuição granulométrica da fração areia no perfil de sedimento estuarino 125

Gráfico 36 - Distribuição de Ca, Mg e Fe no core de sedimento estuarino 127

Gráfico 37 - Distribuição de $\mathrm{Pb}$ e $\mathrm{Zn}$ no core de sedimento estuarino 128

Gráfico 38 - Distribuição dos teores de metais pesados nos tecidos (base seca) das Corbiculas flumineas coletadas ao longo do Rio Ribeira de Iguape 130

Gráfico 39 - Distribuição dos teores de metais pesados nas carapaças das Corbiculas flumineas coletadas ao longo do Rio Ribeira de Iguape 134 


\section{SUMÁRIO}

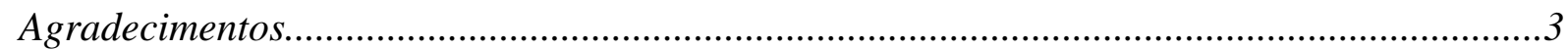

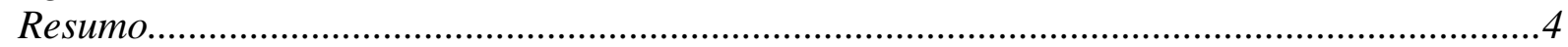

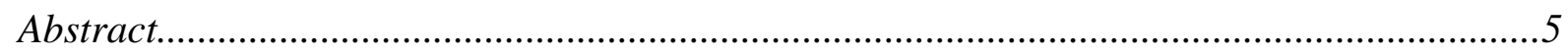

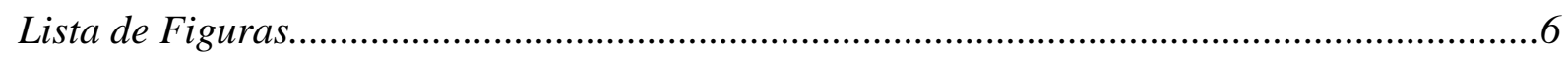

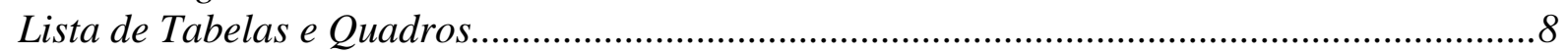

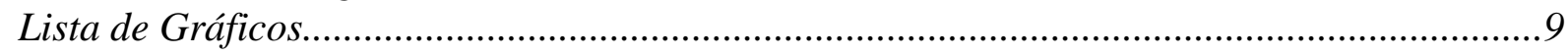

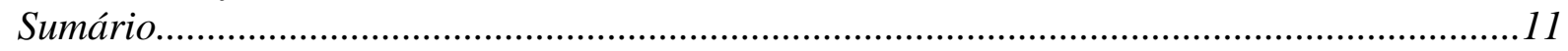

1. Introduçãa

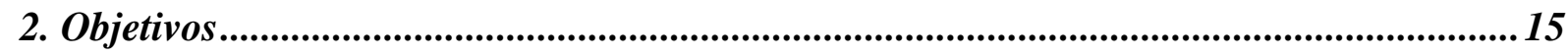

3. Caracterização Da Área ..............................................................................................16

3.1. Localização e Acesso .................................................................................................................16

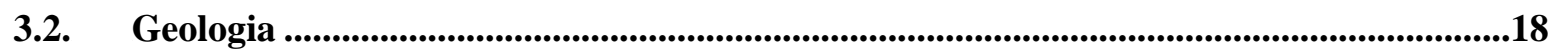

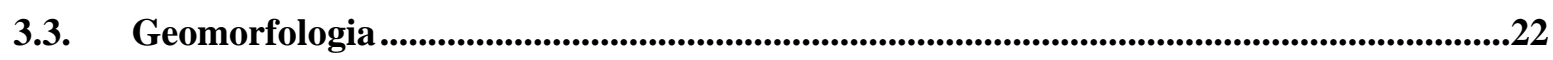

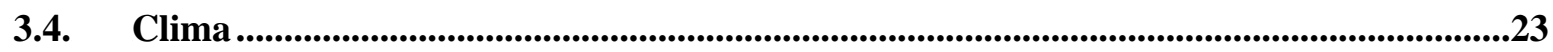

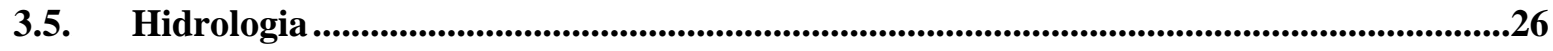

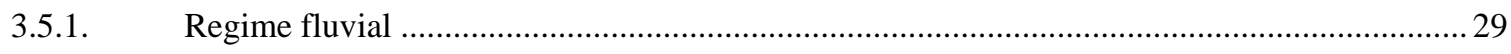

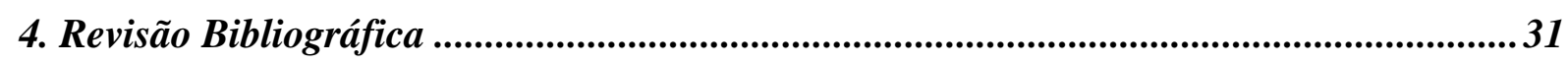

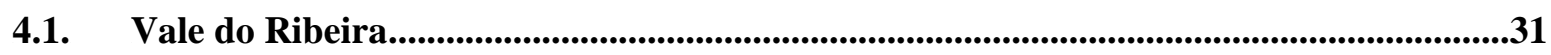

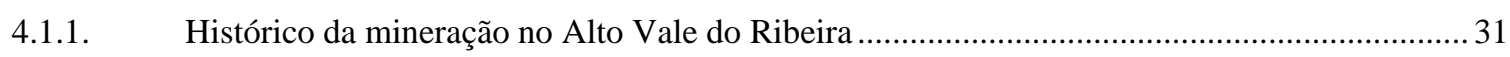

4.1.2. Impactos causados pelas atividades de mineração …………………………………………….... 33

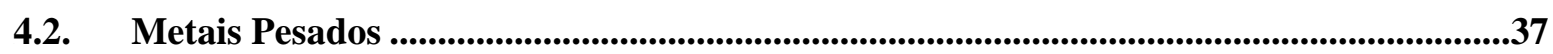

4.2.1. Metais pesados e mineração...................................................................................... 37

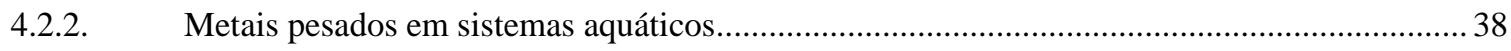

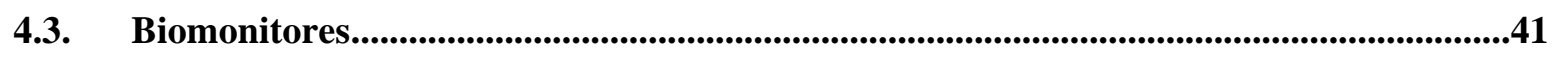

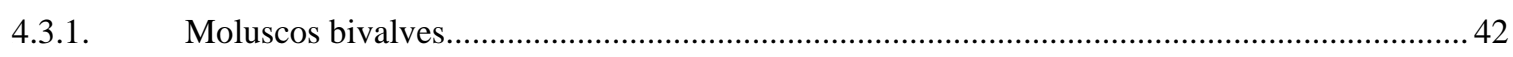

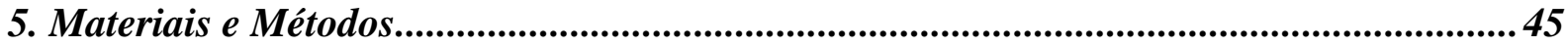

5.1. Resíduos da Mineração.........................................................................................................45

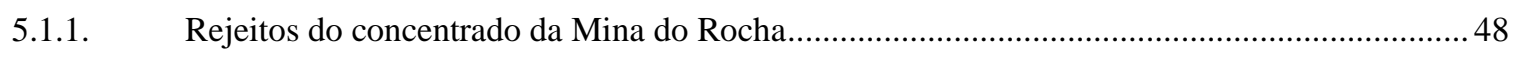

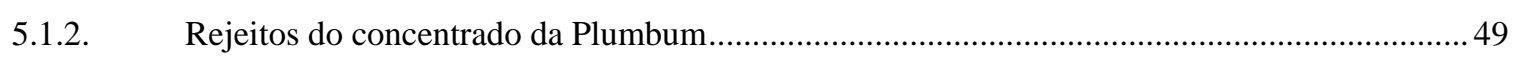

5.2. Resíduos da Metalurgia............................................................................................................52

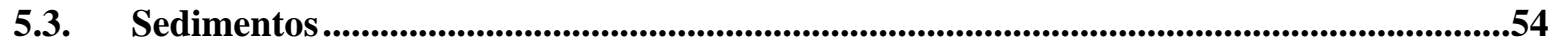

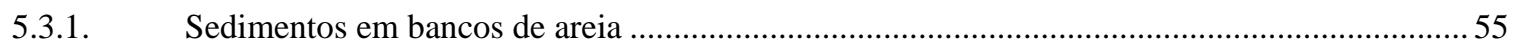




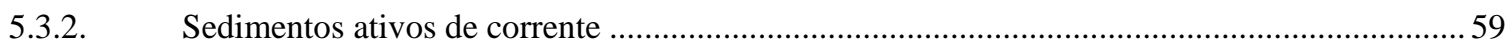

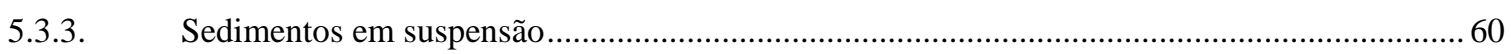

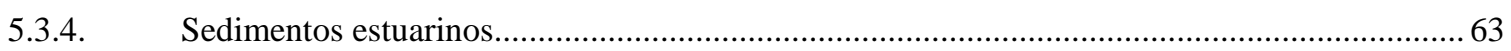

5.4. Biomonitores..............................................................................................................65

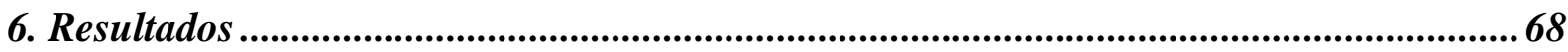

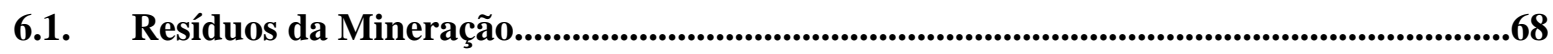

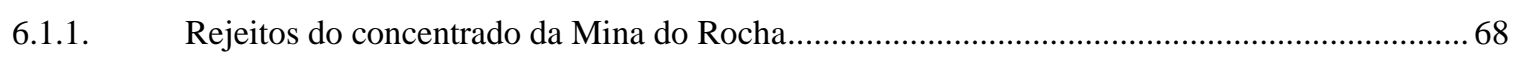

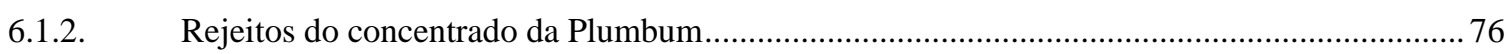

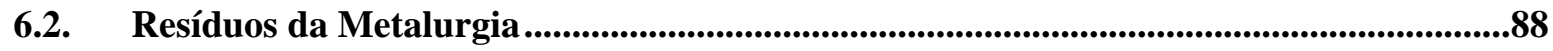

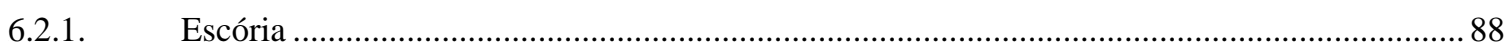

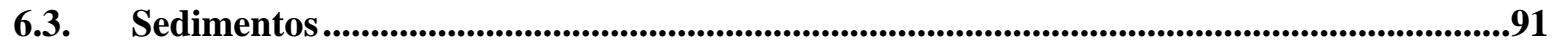

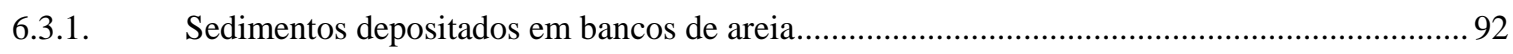

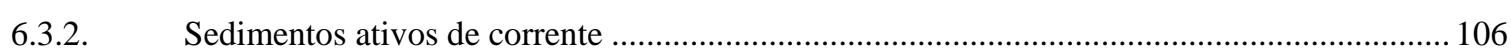

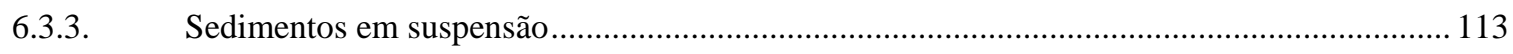

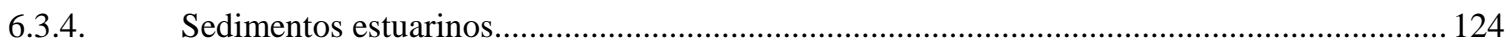

6.4. Biomonitores..........................................................................................................129

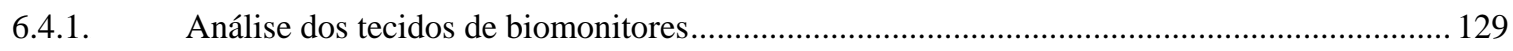

6.4.2. Análise das carapaças de biomonitores....................................................................... 133

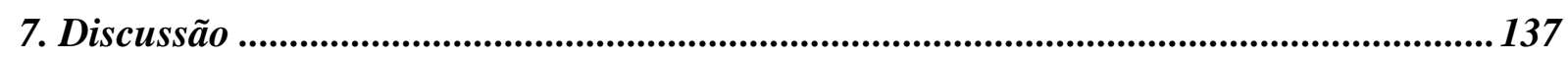

7.1. Resíduos da Mineração e Metalurgia.................................................................137

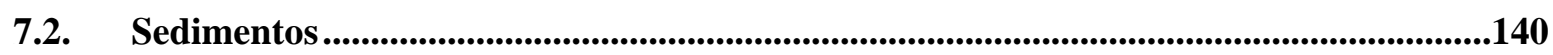

7.3. Biomonitores.......................................................................................................144

8. Conclusões ............................................................................................................ 146

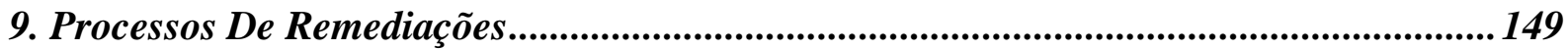

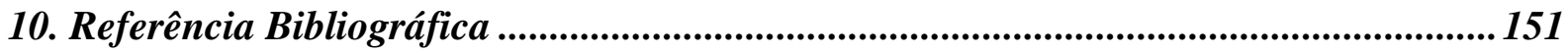

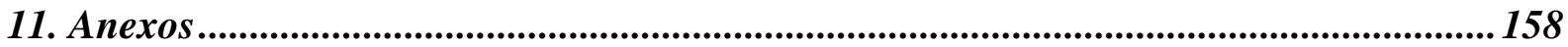




\section{INTRODUÇÃO}

Os processos industriais e minerais, atuantes desde o século passado, contribuíram vastamente para a contaminação do meio ambiente. Os resíduos tóxicos resultantes de tais atividades, muitas vezes enriquecidos em metais pesados, eram depositados ou despejados diretamente nos solos e cursos d'água, sem qualquer tratamento prévio.

A mineração é um dos meios pelos quais os metais pesados entram nos diferentes sistemas (solo, água e atmosfera), pois tal atividade retira do seu equilíbrio geoquímico massas de material rico nestes elementos. Fora do seu equilíbrio, estes materiais tendem a reagir com os demais compartimentos (hidrosfera, atmosfera e biosfera) e a serem transportados ou transformados, persistindo neste meio e causando efeitos danosos por muito tempo, mesmo após o controle das fontes de emissão (SALOMONS, 1995).

Os rejeitos e pilhas de estéril, oriundos das atividades de mineração, são fontes de contaminação em decorrência da presença de metais pesados, principalmente quando estes resíduos apresentam altos teores nestes metais e em minerais sulfetados. Estes metais, geralmente, estão associados a problemas de poluição e contaminação do meio ambiente, devido à sua toxicidade, propriedade de acumulação em organismos e persistência no ambiente.

A antiga Plumbum S/A Indústria Brasileira de Mineração, localizada no município de Adrianópolis (Paraná), produziu e depositou diretamente no Rio Ribeira de Iguape, por aproximadamente 40 anos, resíduos provenientes do beneficiamento do minério (rejeito do concentrado contendo Arsênio-As, Cobre-Cu, Cromo-Cr, Chumbo-Pb, Prata-Ag, Zinco-Zn) e do forno de fundição (escórias contaminadas, principalmente por $\mathrm{Cu}, \mathrm{Zn}$, Níquel-Ni, Cr, Ferro-Fe, $\mathrm{Pb}$ e As). Com o surgimento da lei de proteção ambiental esta prática foi proibida, apenas 4 anos antes da paralisação total das atividades minerais e industriais desta região. Isto acabou por conduzir à deposição destes resíduos, na forma de pilhas, nas proximidades das drenagens sem qualquer medida de contenção, os quais, em sua grande parte, existem até hoje.

Em função das atividades de mineração e fundição não controladas ambientalmente, a partir da década de 80, ainda durante a atividade mineral, foram realizados vários estudos, com o intuito principal de avaliar os efeitos tóxicos causados na Bacia Hidrográfica do Rio Ribeira de Iguape (EYSINK et al., 1990; COMPANHIA DE TECNOLOGIA DE SANEAMENTO AMBIENTAL - CETESB, 1991; FERREIRA, 1994; SILVA, 1997; MORAES, 1997; CORSI, 1999; TESLLER, 2001; CASSIANO, 2001; BOSSO; ENZWEILER, 2003; 
CUNHA, 2003; SÍGOLO et al., 2003; MORAES et al., 2004; FIGUEIREDO, 2005; LOPES Jr. et al., 2005).

Embora se tenha conhecimento de que foram desenvolvidas inúmeras pesquisas nesta região enfocando os problemas ambientais, algumas questões sobre os efeitos tóxicos gerados pelas atividades de mineração (extração, beneficiamento e metalurgia) realizadas no Alto Vale do Ribeira, ainda não foram totalmente esclarecidas:

1. Qual a contribuição efetiva dos rejeitos da mineração e da escória de metalurgia no processo de degradação pela poluição do Rio Ribeira de Iguape?

2. Houve ou não no decorrer do tempo condições de deposição em locais preferenciais destes resíduos ao longo do curso desta drenagem?

3. Algumas entidades de pesquisa e agências ambientais acreditam que o Rio Ribeira de Iguape promoveu e promove processos específicos e naturais de depuração destes contaminantes, será que isto está ocorrendo atualmente neste rio? A biota estaria acumulando estes metais? 


\section{OBJETIVOS}

Esta pesquisa tem por objetivo principal diagnosticar nos diferentes tipos de sedimentos do Rio Ribeira de Iguape qual dos resíduos, lançados nas águas deste rio durante a atividade de mineração realizada à montante, está contribuindo para sua contaminação e se ocorreu ou não depuração natural neste rio pelo impacto causado por tais atividades.

Para atingir esta finalidade foram traçados os seguintes objetivos específicos:

1. Caracterizar física e quimicamente os resíduos provenientes do beneficiamento do minério (rejeito do concentrado) e o resíduo proveniente do alto forno de fundição (escória). Determinar qual a participação efetiva destas duas fontes na contaminação dos sedimentos e em que porção preferencial do rio elas estão sendo mais depositadas;

2. Caracterizar física e quimicamente os sedimentos do Rio Ribeira de Iguape, quais sejam: sedimentos em bancos de areia, ativos de corrente, em suspensão e estuarinos;

3. Avaliar o grau de contaminação dos resíduos e dos sedimentos, a partir da comparação dos teores de metais pesados obtidos com valores de referência da Associação Brasileira de Normas Técnicas (ABNT) para os resíduos de mineração e com os do Canadian Council of Ministers of the Environment (CCME) para os sedimentos; como indicativos de eventuais problemas de ordem ambiental;

4. Empregar uma variedade de organismo biomonitor, visando avaliar o grau de comprometimento deste rio diante do lançamento dos resíduos de mineração em suas águas;

5. Propor procedimentos de remediação e monitoramento. 


\section{CARACTERIZAÇÃo DA ÁreA}

\subsection{LOCALIZAÇÃO E ACESSO}

A área de estudo insere-se em parte da Bacia Hidrográfica do Rio Ribeira de Iguape, compreendendo os municípios de Cerro Azul (PR), Adrianópolis (PR), Iporanga (SP), Eldorado (SP), Sete Barras (SP), Juquiá (SP), Registro (SP) e Iguape (SP). Esta região está localizada aproximadamente entre as latitudes $24^{\circ} 00^{\prime} \mathrm{S}$ e $24^{\circ} 45^{\prime} \mathrm{S}$ e longitudes $47^{\circ} 30^{\prime} \mathrm{W}$ e 49³0'W. O acesso a esta porção da Bacia Hidrográfica do Rio Ribeira de Iguape é realizado pela rodovia federal BR-116 (Regis Bittencourt) saindo de São Paulo em direção à Curitiba e pelas rodovias estaduais SP-165, SP-222 e SP-250, conforme exibe a figura 1. 


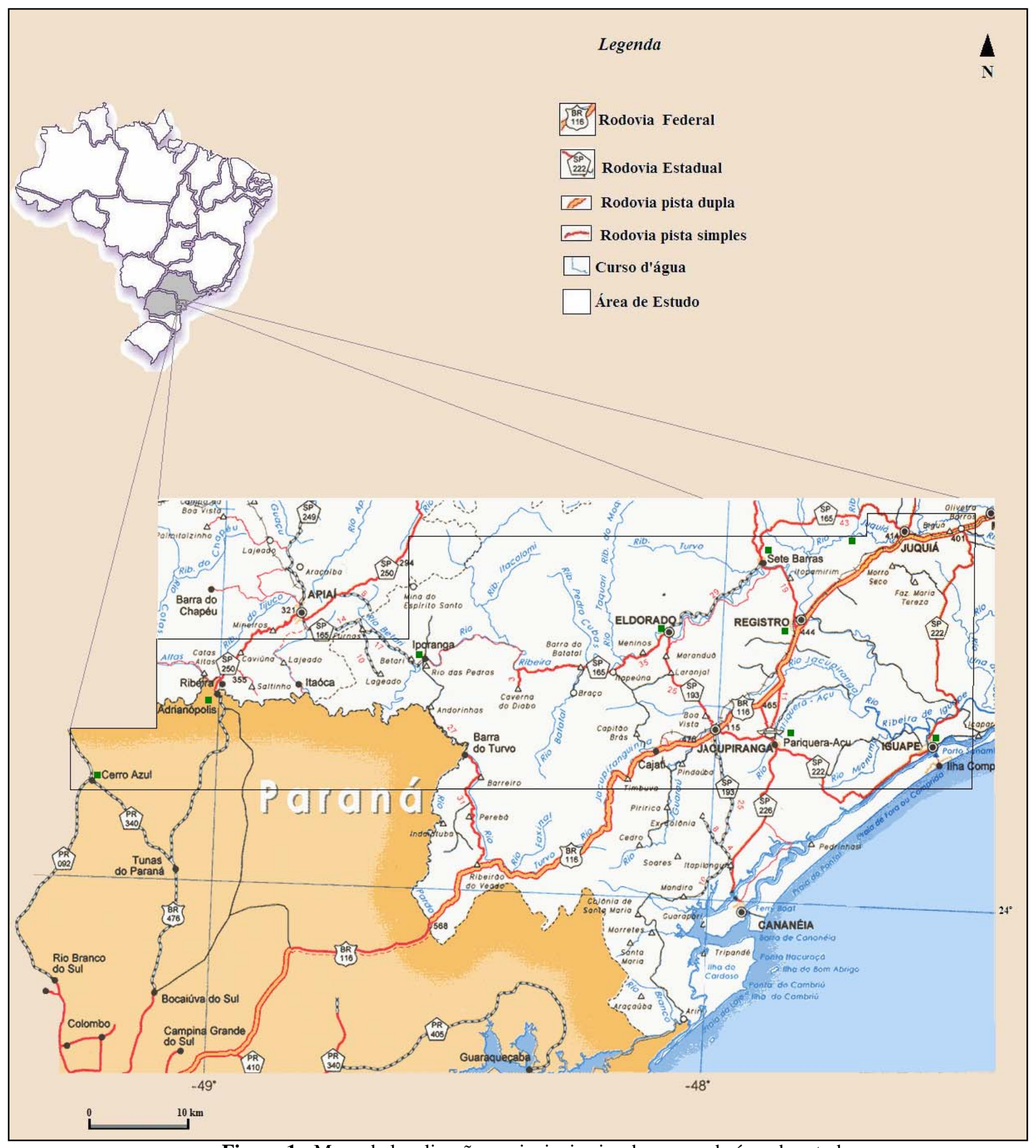

Figura 1 - Mapa de localização e principais vias de acesso da área de estudo Modificado de Departamento de Estradas de Rodagem - DER (2006) 


\subsection{GeOLOGiA}

A região do Vale do Ribeira exibe ampla variedade de rochas com características distintas que podem ser agrupadas, segundo Centro Tecnológico da Fundação Paulista de Tecnologia e Educação - CETEC (1999), em três grandes domínios geológicos: A) rochas metamórficas pré-cambrianas (apresentam estruturas orientadas: xistosas, migmatíticas e gnáissicas) e cataclásticas (geradas por esforços de cisalhamento em zonas de falhamentos); B) rochas magmáticas (representadas por corpos intrusivos graníticos, básicos e alcalinos) e C) coberturas sedimentares cenozóicas (sedimentos inconsolidados).

\section{A) Rochas metamórficas pré-cambrianas e cataclásticas}

Representando o primeiro domínio estas rochas, exibem em geral, orientações pronunciadas, sendo mais freqüentes as estruturas xistosas (caracterizadas pelo alinhamento planar dos minerais em xistos e filitos) e migmatíticas (identificadas pelas intercalações de rochas claras e escuras, em geral foliadas, formando bandamentos que podem ser nítidos a pronunciados ou às vezes até quase ausentes). São relativamente abundantes as estruturas lineares que ocorrem em granitos ou maciços granitóides. Destacam-se também, as orientações ou foliações presentes nos gnaisses e estruturas fraturadas, ou miloníticas das rochas cataclásticas. Todas estas rochas metamórficas pertencem ao Grupo Açungui, Formação Setuva, Complexo Turvo-Cajati e Complexo Costeiro. Estas litologias são dominantes na Bacia Hidrográfica do Rio Ribeira de Iguape (CETEC, 1999).

Ainda conforme Cetec (1999), as rochas do Grupo Açungui originadas sob condições de metamorfismo mais baixo são compostas predominantemente por metassedimentos, apresentando orientações pronunciadas, determinadas pelos planos de xistosidade e orientadas predominantemente segundo a direção NE/SW. Litologicamente, estas rochas são divididas em: argilosas (formadas por filitos e mica-xistos), arenosas (principalmente, formadas por quartzitos e meta-arenitos) e carbonáticas (formadas por mármores calcíticos e dolomíticos). Integram ainda o Grupo Açungui rochas metabásicas e migmatitos de estruturas variadas. As primeiras são constituídas principalmente por anfibolitos, metagabros e díques metabasíticos.

As rochas do Complexo Costeiro são bastante heterogêneas e antigas, resultantes de diferentes eventos geológicos-tectônicos e alto grau metamórfico. Litologicamente, este complexo é composto por migmatitos e gnaisses, ocorrendo, subordinadamente, xistos, quartzitos, rochas calcossilicatadas, metabasitos e granulitos. O metamorfismo presente é 
de fácies anfibolito a granulito e as estruturas apresentam-se orientadas segundo a direção NE-SW. Esta unidade distribui-se ao longo de uma larga e descontínua faixa de direção aproximada NE/SW, ao sul da Falha de Cubatão. As rochas migmatíticas predominantes se espalham por toda área de ocorrência do Complexo Costeiro e incluem paleossomas de natureza diversa (xistosos, anfibolíticos, gnáissicos, quartzíticos e calcossilicáticos).

As litologias do Complexo Turvo-Cajati são encontradas no extremo sul da região, entre o Rio Pardo (Falha de Cubatão) e o Rio Ribeira de Iguape, conforme Cetec (1999). Este complexo é formado por micaxistos, ardósias, filitos, mármores, dolomitos, calcáreos, metabasitos, quartzitos, rochas calcossilicatadas, gnaisses, anfibolitos e migmatitos. O metamorfismo presente é variável da fácies xisto-verde a anfibolito alto, com as estruturas orientadas preferencialmente na direção E-W.

A Formação Setuva ocorre na porção oeste da bacia, sendo litologicamente constituída por orto e paragnaisses e subordinadamente por micaxistos, anfibolitos, talcoxistos e metaultrabasitos. As foliações em virtude da xistosidade e/ou bandamento gnáissico orientam-se, predominantemente, na direção NE.

A Formação Água Clara, também inserida no Grupo Açungui, cobre cerca de 30\% da área da bacia (porção referente ao Alto Ribeira) e é constituída por: rochas metassedimentares vulcanoclásticas, metabásicas vulcânicas, rochas calciossilicáticas, anfibólio xistos, quartzitos, granada-clorita-biotita xistos, metacherts, metatufos básicos e intermediários, metabasitos e cornubianitos.

Resumidamente, o Grupo Açungui constitui a mais extensa unidade pré-cambriana da bacia, situando-se numa faixa alongada na porção norte da área, sendo a Falha de Cubatão o seu limite sul. Litologicamente é constituído por migmatitos, gnaisses, xistos, filitos, quartzitos, anfibolitos, mármore e dolomitos. As foliações, em geral, estão orientadas segundo direção E-NE.

\section{B) Rochas magmáticas}

As suítes sintectônicas localizam-se dominantemente na porção norte da bacia. Representando o segundo domínio, estas rochas incluem suítes sintectônicas e póstectônicas, formando grandes batólitos e stocks, destacando-se os maciços de Três Córregos (borda oeste) e Agudos Grandes (porção norte). Pertencem à fácies Cantareira, onde as rochas mais comuns são os granito-gnaisses, de granulação fina a média, foliação marcante e sem grandes variações composicionais ou texturais. As suítes graníticas póstectônicas localizam-se na borda sul da bacia, entre as cidades de Campina Grande e Jacupiranga, e caracterizam-se por granitos de acentuada alcalinidade, isótropos, de cor 
cinza clara e rósea, granulação média a grossa e textura hipidiomórfica xeromórfica granular.

As rochas do embasamento pré-cambriano encontram-se recortadas por numerosos diques de diabásio, subverticais, com extensões que chegam a alcançar dezenas de quilômetros.

As intrusões ultrabásicas-alcalinas produziram corpos intrusivos, evidenciados nos maciços de Jacupiranga, Morro do Serrote, Itapirapuã e Cananéia, além de corpos de menor extensão como o Morro de São João e Morrote da Ilha Comprida. Este magmatismo é responsável por algumas ocorrências de minerais na Bacia Hidrográfica do Rio Ribeira de Iguape (CETEC, 1999).

Rochas alcalinas intrusivas ocorrem esparsamente ao longo da bacia, destacando-se os corpos de Juquiá, Jacupiranga e Morro do Serrote / Mato Preto. Na área da bacia, são comuns intrusões básicas na forma de diques ou sills, porém estas são de pouca expressão regional.

Todas as rochas pré-cambrianas, assim como as intrusivas graníticas, foram submetidas a uma intensa tectônica. Esta é identificada por numerosos falhamentos e fraturamentos, responsáveis pelas rochas cataclásticas / miloníticas.

\section{C) Coberturas sedimentares cenozóicas}

O último domínio é representado pelas coberturas sedimentares cenozóicas, compostas por 4 unidades geológicas, originadas em ambientes continentais e marinhos. Estas formações foram geradas por fatores complexos, destacando-se as atividades tectônicas, oscilações do nível do mar e variações climáticas durante o período Cenozóico. Fazem parte deste grupamento as seguintes formações: Pariquera-Açu, Cananéia, Sedimentos Continentais Indiferenciados e Sedimentos Aluvionares.

A Formação Pariquera-Açu corresponde a antigos terraços de sedimentação fluvial, situados acima do nível atual do Rio Ribeira de Iguape, sendo formada por siltitos arenoargilosos e areias de origem fluvial com intercalações de cascalho. Ocorrem em áreas mais expressivas nas bacias do Rio Jacupiranga e do Rio Ribeira de Iguape.

A Formação Cananéia constitui as areias marinhas finas não consolidadas, finas, homogêneas, bem selecionadas e freqüentemente limonitizadas. Os depósitos de mangue, também integrantes desta formação, estão distribuídos de forma descontínua, associados a desembocaduras de rios e canais estuarinos, dispostos para montante dos cursos d'água.

Os Sedimentos Continentais Indiferenciados envolvem sedimentos elúviocoluvionares de natureza areno-argilosa. Correspondem aos depósitos de pé de encosta, 
dispostos em talus e rampas, de constituição variável, contém desde a fração argilo-arenosa até matacões.

Os Sedimentos Aluvionares, presentes nas várzeas dos rios costeiros têm constituição variada, em função da dimensão da área drenada. As várzeas do Ribeira de Iguape apresentam maior diversidade granulométrica, composta por camadas argilosas, siltosas e arenosas, com intercalações lenticulares de cascalho.

Resumidamente, segundo Daitx (1996), a região do Vale do Ribeira insere-se no domínio de duas grandes unidades geotectônicas, denominadas de Faixa de Dobramentos Apiaí (que contém a quase totalidade das ocorrências de minério de $\mathrm{Pb}$ ) e Maciço de Joinvile. Conforme este mesmo autor, a geologia do Vale do Ribeira é caracterizada pela presença de faixas com estruturação geral NE-SW, alternando conjuntos de metamorfitos de baixo e/ou médio grau (de noroeste para sudeste: Itaiacoca, Abapã, Água Clara, Antinha, Lageado, Iporanga, Votuverava, Perau, Capiru, Setuva e Turvo-Cajati), complexos granitóides (Cunhaporanga, Três Córregos e Agudos Grandes) e complexos gnáissicogranitóide (Apiaí-Mirim) e/ou gnáissico-migmatítico/granulítico (Cristalino ou Costeiro).

Em decorrência desta grande variedade de formações rochosas e eventos tectônicos, a região do Vale do Ribeira é detentora de importante potencial mineral, ocorrendo grande variedade de substâncias minerais, desde ferrosos, metálicos não ferrosos e preciosos, além de minerais industriais diversos e materiais naturais destinados à indústria de construção civil.

Cerca de 95\% das mineralizações de $\mathrm{Pb}$ alojam-se em rochas carbonáticas das unidades Lageado e Perau, com um pequeno número de ocorrências nas unidades Água Clara e Itaiacoca. De acordo com Fleischer (1976) os jazimentos de Pb do Vale do Ribeira compõem dois tipos principais de mineralizações, denominadas de Panelas e Perau.

As jazidas do tipo Panelas apresentam mineralizações epigenéticas com corpos filonares discordantes das rochas encaixantes, tendo forte controle estrutural e com os veios mineralizados preenchendo fraturas associadas à estrutura sinformal e antiformal do contexto estrutural regional. As diversas jazidas do tipo Panelas são formadas quase que exclusivamente por galena e pirita, com elevado teor de prata, mineralizados na forma de veios discordantes das rochas carbonáticas encaixantes (DAITX, 1996 apud MORAES, 1997). Estas jazidas, conforme datação realizada por Tassinari et al. (1990), exibiram idades entre 1,1 a 1,4 bilhões de anos.

De acordo com Moraes (1997), as jazidas do tipo Perau caracterizam-se por serem singenéticas concordantes, associadas às formações ferríferas e/ou baritíferas, dispondo-se, 
na porção inferior da Formação Perau, Grupo Setuva, com um horizonte litoestratigráfico constituído de quartzitos, rochas carbonáticas impuras e quartzo-micaxistos com intercalações subordinadas de anfibolitos. São conhecidas três jazidas de Pb e Zn (Perau, Canoas e Araçazeiro) e duas de barita associadas (Pretinhos e Águas Claras). Estas jazidas, com base em datações $\mathrm{Pb}-\mathrm{Pb}$ em galenas, apresentaram idades entre 1,5 a 1,7 bilhões de anos (TASSINARI et al., 1990).

\subsection{GEOMORFOLOGIA}

A Bacia Hidrográfica do Rio Ribeira de Iguape está inserida em sua grande maioria na Província Costeira e em porções menores no Planalto Atlântico, apresentando relevo acidentado e amplos desníveis topográficos (ALMEIDA, 1964).

A região do Planalto Atlântico situa-se nos limites setentrionais da Bacia Hidrográfica do Rio Ribeira de Iguape e é caracterizada por apresentar terras altas que ocupam a posição de cimeira nos interflúvios e limites desta bacia (CETEC, 1999).

A Província Costeira, conforme já abordado, é mais expressiva em área e é drenada diretamente para o mar, constituindo o rebordo do Planalto Atlântico (CETEC, 1999). Ainda conforme Cetec (1999), esta província exibe enorme complexidade de formas de relevos, formando na região serrana escarpas abruptas e festonadas, desenvolvidas ao longo de anfiteatros sucessivos, separados por espigões. A Província Costeira é constituída por 3 zonas geomorfológicas: Serrania Costeira, Morraria Costeira e as Baixadas Litorâneas.

A Serrania Costeira é formada por vales profundos e encaixados, com grandes amplitudes topográficas. Esta zona é subdivida em 5 subzonas, sendo que a Serra de Paranapiacaba merece maior destaque, por constituir a extensa e contínua vertente norte da Bacia do Rio Ribeira de Iguape e a faixa de cristas paralelas da região Ribeira-ApiaíIporanga, destacando-se pela ocorrência de relevos do tipo Montanhas com Vales Profundos, Serras Restritas e Morros Paralelos.

A zona de Morraria Costeira ocupa a região central do Vale e do Baixo Ribeira, no sopé dos relevos montanhosos da Serrania Costeira, apresentando relevos arrasados com elevações raramente acima de 100 - 200 m do nível do mar. É composta principalmente por colinas, morrotes e morros que se destacam da planície costeira e das planícies aluviais no trecho inferior do Rio Ribeira de Iguape, sendo que também fazem parte desta zona as formações originadas por processos de pedimentação e intensa sedimentação fluvial (destacam-se as seguintes feições: rampas, terraços antigos e intermediários, cones de dejeção e planícies aluviais). Resumidamente, os relevos característicos desta zona são: 
Planícies Aluviais, Morrotes em Meia Laranja, Morros de Topos Achatados, Mar de Morros, Morros Paralelos, Morros Isolados, Serras Alongadas e Montanhas.

As Baixadas Litorâneas abrangem as Planícies Costeiras, juntamente com os Manguezais e os Terraços Marinhos, estes últimos, de acordo com Cetec (1999), são expressivos apenas no trecho final do Rio Ribeira de Iguape. As Baixadas Litorâneas agrupam áreas de relevo plano ou colinoso que sofreram influência direta da sedimentação marinha ou fluvial do Rio Ribeira de Iguape, incluindo a região lagunar de Iguape-Cananéia e as colinas sub-litorâneas de altitude inferior a $60 \mathrm{~m}$.

O Vale do Ribeira foi entalhado por processos contínuos de dissecação realizados pelo Rio Ribeira de Iguape e seus afluentes nos corpos rochosos, produzindo amplo anfiteatro erosivo. Este anfiteatro é composto por extensas áreas serranas, profundamente entalhado em forma de vales encaixados, escarpas abruptas e festonadas, conectando-se com uma seqüência de planícies sedimentares, localizadas próximo à beira mar (CETEC, 1999).

Na maior parte da bacia, o relevo é montanhoso, com declividades acima de $15 \%$ e encostas com amplitudes locais de 100 a 300 m (relevos de morros isolados) e amplitudes locais superiores a $300 \mathrm{~m}$ (relevo montanhoso). Estas áreas correspondem às porções de cabeceiras e médio curso dos Rios Ribeira de Iguape e Juquiá, situados nos planaltos paranaense e paulista, devido ao recuo da Serra do Mar.

$\mathrm{Na}$ porção central da bacia, junto à foz do Rio Juquiá, o relevo é suave, correspondente às planícies desenvolvidas ao longo dos rios Ribeira, Juquiá e Jacupiranga. Esta suavidade é interrompida pela presença de maciços rochosos e morros isolados, cujas declividades médias não ultrapassam a 15\% e as amplitudes locais são de no máximo 100m (SECRETARIA DE ESTADO DO MEIO AMBIENTE - SÃO PAULO, 1992).

A faixa litorânea desta região é uma das áreas sedimentares mais extensas do litoral paulista, com largura em torno de $10 \mathrm{~km}$. Situada pouco acima do nível do mar, as altitudes não são superiores a $10 \mathrm{~m}$. A topografia desta região é marcada por planícies de cordões litorâneos, vegetação de restinga, e manguezais, desenvolvidos ao longo de extensos corpos de águas salobras.

\subsection{CLIMA}

O clima da Bacia Hidrográfica do Rio Ribeira de Iguape e Litoral Sul pode ser classificado, de modo geral, como tropical úmido com ligeira variação entre as zonas costeiras (Litoral Sul) e o alto da Serra de Paranapiacaba (SÃO PAULO, 1992). 
De acordo com a classificação dos tipos climáticos de Köppen, 5\% da Bacia Hidrográfica do Rio Ribeira de Iguape é do tipo tropical úmido sem estação seca, $50 \%$ é do tipo subtropical úmido com verão quente e o restante (45\%) é do tipo subtropical úmido com verão fresco. Estes limites climáticos não são perfeitamente definidos e variam anualmente (CETEC, 1999).

Esta região sofre influência de duas massas de ar, a Tropical Atlântica (influi na distribuição de chuvas) e a Polar Atlântica (responsável pelas baixas temperaturas), sendo que a atuação da massa de ar Tropical Atlântica é mais intensa.

À distribuição espacial e temporal das chuvas é de aproximadamente 1.400 mm/ano, em média (CETEC, 1999), de tal forma que o trecho mais chuvoso da bacia envolve as áreas drenadas pelo baixo curso do rio, a jusante de Registro.

Para verificar a média pluviométrica nas áreas de interesse deste estudo foram obtidos dados de uma série histórica de 1969 até 1999 nas estações pluviométricas do Departamento de Águas e Energia Elétrica - DAEE (2006), localizadas em Eldorado (Gráfico 1), Sete Barras (Gráfico 2) e Registro (Gráfico 3). A análise destes dados mostrou que os meses mais chuvosos vão de dezembro até março, sendo janeiro e fevereiro os de maior pluviosidade. Os meses com menor precipitação pluviométrica ocorrem de abril até agosto, sendo este último o de menor índice pluviométrico (Gráficos 1, 2 e 3).

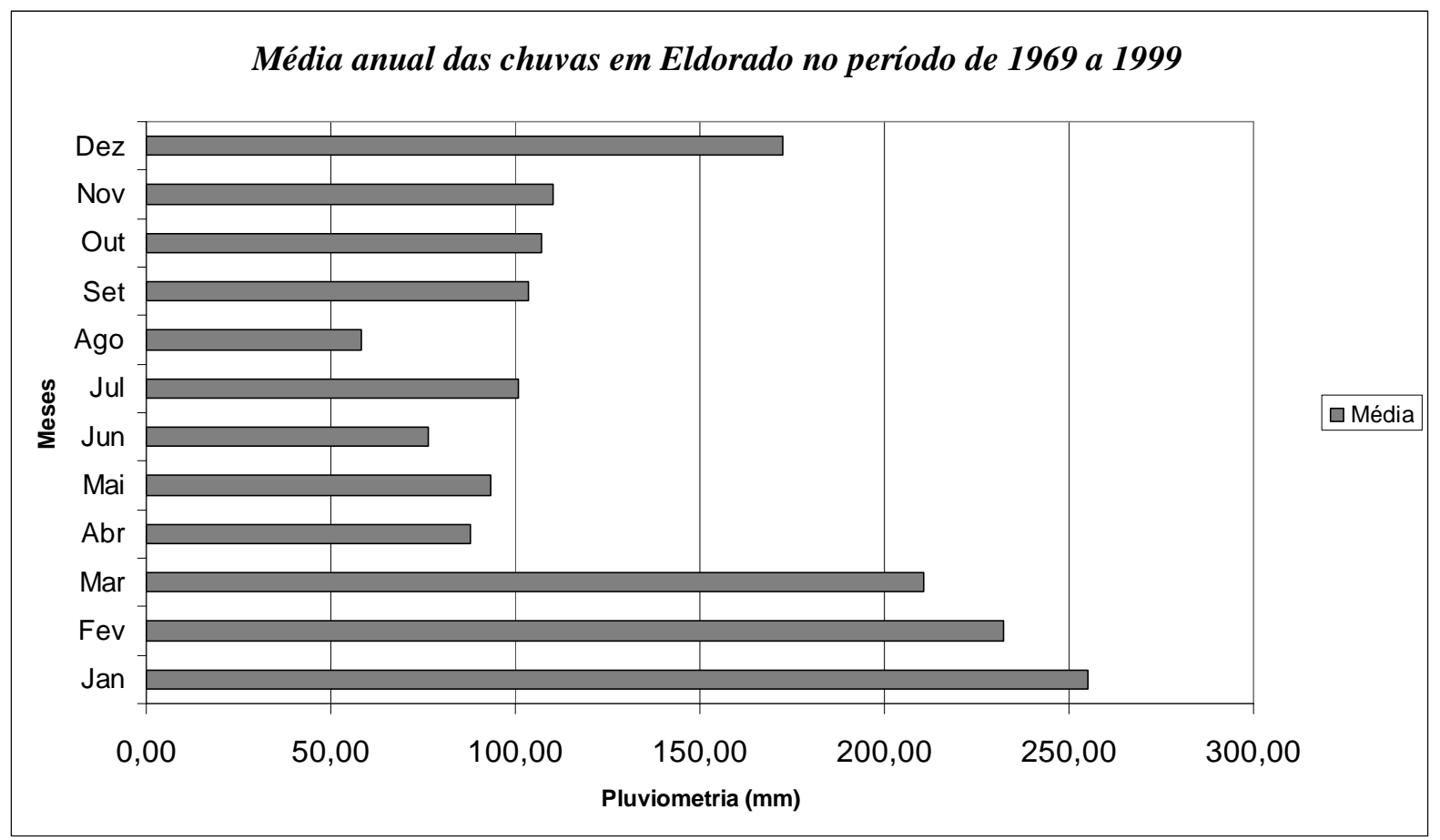

Gráfico 1 - Média anual das chuvas em Eldorado no período histórico de 1969 a 1999 


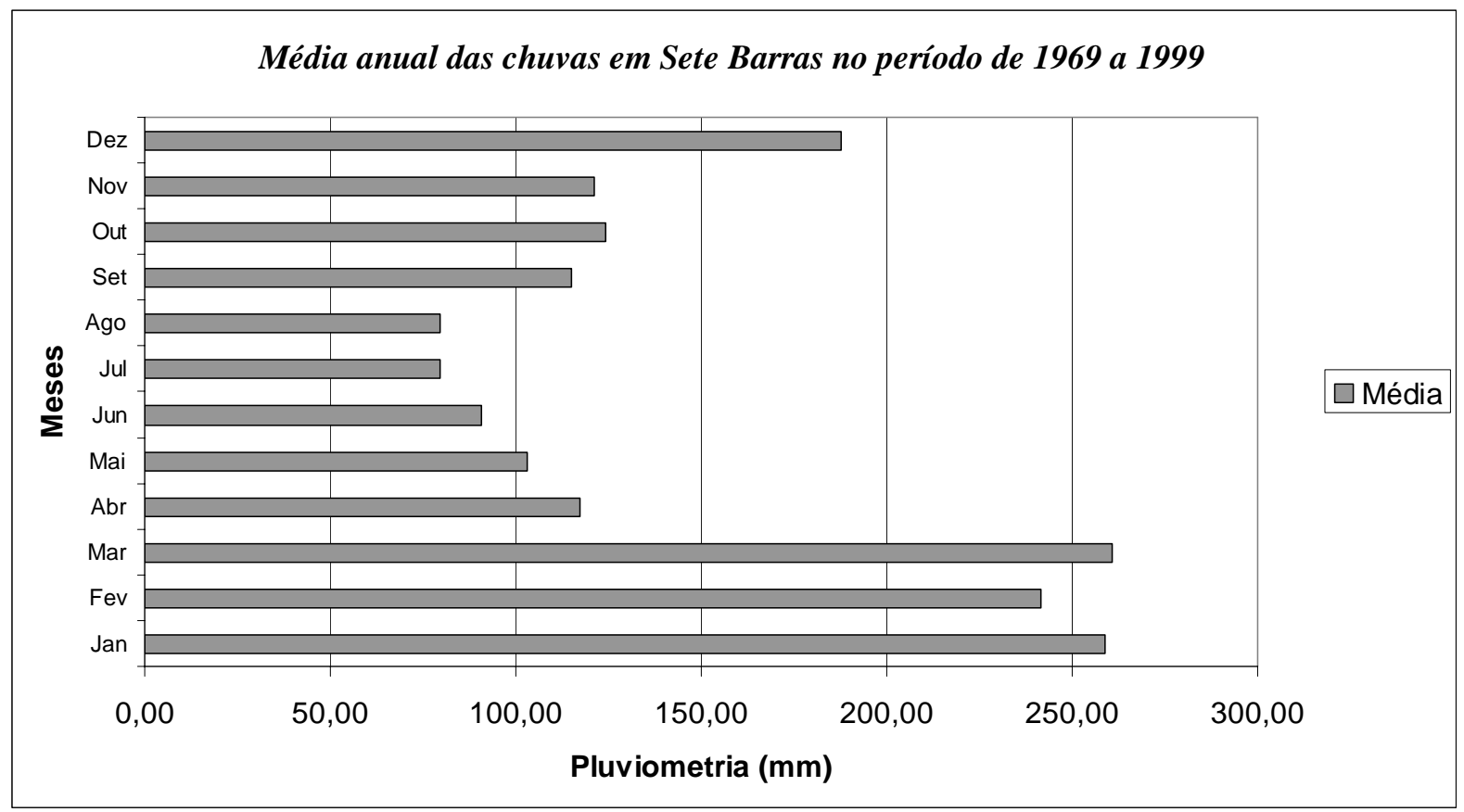

Gráfico 2 - Média anual das chuvas em Sete Barras no período histórico de 1969 a 1999

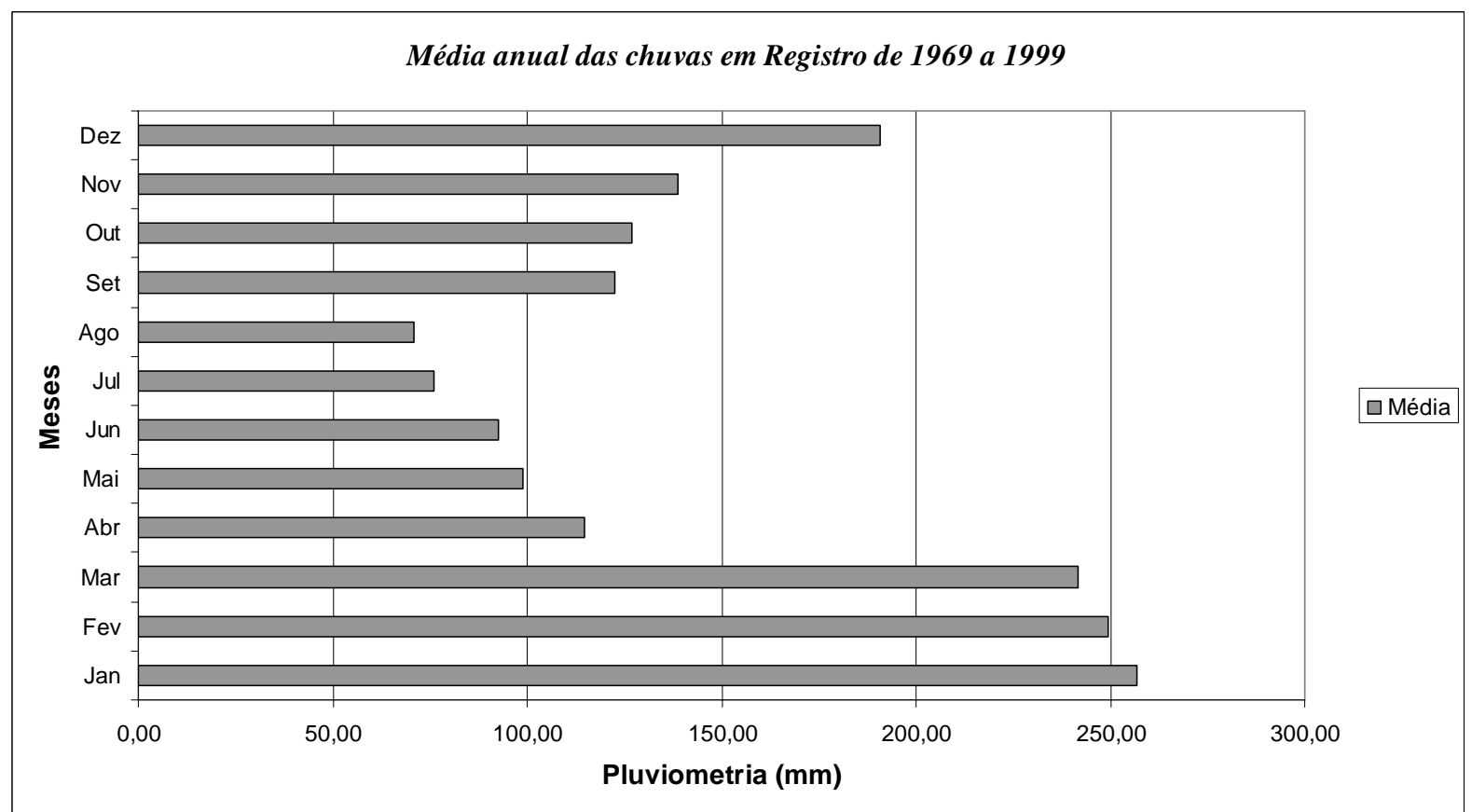

Gráfico 3 - Média anual das chuvas em Registro no período histórico de 1969 a 1999

De modo geral, na série histórica de 1969 até 1999, o ano com maior índice pluviométrico foi registrado em 1983, com média anual de 218,51 mm em Eldorado, média anual de 239,20 mm em Sete Barras e média anual de 242,44 mm em Registro. Na estação pluviométrica de Eldorado, durante estes 30 anos, a maior média observada foi de 539,10 $\mathrm{mm}$ em março de 1992, enquanto que a menor foi de 3,10 mm em julho de 1985. Em Sete Barras, a maior média pluviométrica ocorreu em julho de 1976 e foi de 1.112,30 mm, já a 
menor foi de 3,30 mm em setembro de 1994. Na estação localizada em Registro a maior pluviosidade média foi de 474,66 mm em fevereiro de 1996 e a menor em de 1,10 mm em julho de 1985.

\subsection{HidROLOGIA}

A Bacia Hidrográfica do Rio Ribeira de Iguape situa-se na região Sudeste do Brasil, confrontando-se com as bacias dos rios Tietê ao norte, Paranapanema a oeste, Iguaçu ao sul e pequenos cursos d'água da vertente atlântica a leste, sendo sua foz no Oceano Atlântico (CETEC, 1999). Apresenta feição semelhante a uma "grande ferradura", emoldurada pela Serra do Taquari ao sul, Serra do Itatins ao nordeste e Serra de Paranapiacaba ou do Mar ao noroeste, oeste e sudeste distantes até $20 \mathrm{~km}$ da atual linha de costa (MORAES, 1997 apud TESSLER, 2001).

Esta bacia ocupa uma área de aproximadamente $28.000 \mathrm{~km}^{2}$ e localiza-se no extremo nordeste do Paraná e sudeste de São Paulo (LOPES Jr., 2005). De acordo com Tessler (2001), 61\% da área total da Bacia Hidrográfica do Rio Ribeira de Iguape encontrase nos limites do Estado de São Paulo e o restante (39\% do total da área da bacia) no Estado do Paraná. O principal tributário do Ribeira é o Rio Juquiá, cuja foz está localizada $10 \mathrm{~km}$ a montante de Registro, ocupando uma área de aproximadamente $5.280 \mathrm{~km}^{2}$.

A extensão do Rio Ribeira de Iguape é de $470 \mathrm{~km}$, entre a sua nascente localizada na vertente leste da Serra de Paranapiacaba (Estado do Paraná) e a sua foz no Oceano Atlântico (Estado de São Paulo), nas proximidades da cidade de Iguape (Barra do Ribeira). Inicialmente, ele recebe a denominação de Rio Ribeirinha, seguindo rumo NE encontra o Rio Açunguí, nas proximidades da cidade de Cerro Azul no Paraná, a uma altitude de $380 \mathrm{~m}$ (Figura 2).

A partir deste encontro, ele recebe o nome de Rio Ribeira de Iguape, desenvolvendo seu curso por entre os contrafortes da Serra de Paranapiacaba, em vales profundamente entalhados e encachoeirados até as proximidades da cidade de Itaoca. Neste trecho, o Rio Ribeira exibe um comportamento de corredeiras, imposto pelas características geomorfológicas (Figura 2) e climáticas atuantes na região.

Após Itaoca, até um pouco à jusante da cidade de Eldorado, o Rio Ribeira de Iguape apresenta um padrão meandrante onde passa a exibir, em suas faces côncavas, a deposição de sedimentos em forma de barras de pontal (MORAES, 1997). Em direção à sua foz, esta planície amplia-se em leque, formando grandes áreas alagadiças que, nas proximidades da cidade de Iguape no Estado de São Paulo, sob influência estuarina, apresenta o desenvolvimento de extensas áreas ocupadas por manguezais. 
Nas proximidades da cidade de Iguape no Estado de São Paulo, situa-se o canal artificial do Valo Grande, este faz a ligação da calha original do rio à região do Mar Pequeno. Este canal foi escavado em 1837, com a função de criar facilidades para o transporte de cargas entre a lagoa de Porto do Ribeira e a região do Mar Pequeno, onde se localiza o porto responsável pelo escoamento dos produtos agrícolas e minerais produzidos no interior (MORAES, 1997).

Segundo Tessler (2001), o porto de Iguape situava-se no interior do sistema costeiro (Mar Pequeno), passando a ser influenciado, após a abertura do Valo Grande, pela descarga fluvial do Rio Ribeira de Iguape, estando associado acelerado processo de assoreamento, não apenas dos sedimentos em suspensão, carreados pelo rio, mas também de sedimentos arenosos transportados por tração, a partir da erosão das margens do Valo Grande. Este canal artificial, com extensão inferior a $4 \mathrm{~km}$, escavado em profundidades menores de $2 \mathrm{~m}$ e largura de aproximadamente $4,4 \mathrm{~m}$, foi rapidamente erodido pelo curso fluvial.

O canal artificial do Valo Grande foi fechado em agosto de 1978, já com cerca de 250 $\mathrm{m}$ de largura e $7 \mathrm{~m}$ de profundidade, em função da construção de uma barragem que fechava a intercomunicação do sistema fluvial com o sistema costeiro. Depois desta construção, entre 1978 a 1983, o Rio Ribeira de Iguape passou a direcionar todo seu fluxo através do seu leito original. Com o rompimento da barragem, em 1983, as águas do Rio Ribeira de Iguape voltaram a se dividir entre o Valo Grande e seu canal original. Hoje, o Rio Ribeira de Iguape adotou o Valo Grande como sendo seu leito principal, escavando e carreando grandes volumes de materiais em suspensão e sedimentos para a região do Mar Pequeno (TESSLER, 2001). 


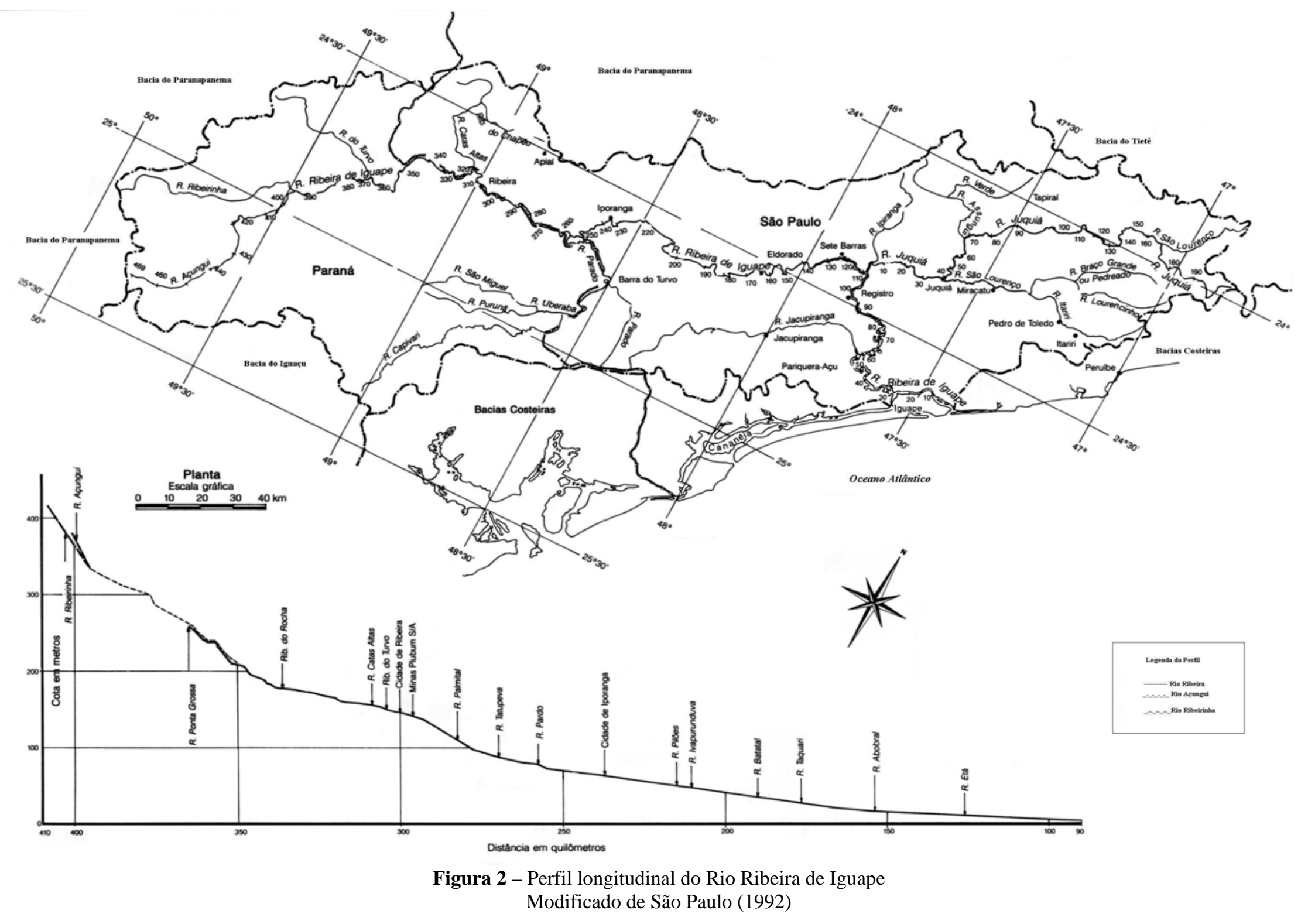




\subsubsection{Regime fluvial}

Este rio é considerado um sistema fluvial de regime subtropical (GEOBRÁS, 1966 apud TESSLER, 2001), com cheias pronunciadas no verão e estiagem no inverno, sendo que seu regime fluvial acompanha de perto o regime pluvial.

As condições climáticas da região do Vale do Ribeira (altamente favoráveis à ocorrência de chuvas do tipo frontal, de grande intensidade e duração, que tendem a produzir grandes volumes de deflúvio superficial), somadas com as características morfológicas da bacia favorecem a ocorrência de grandes cheias. Segundo Daee (1999), as cheias do Rio Ribeira do Iguape são fenômenos físico-naturais, caracterizadas pela ocorrência de extravasamento das águas da calha natural em direção às várzeas, onde se situam as cidades sede dos municípios, bairros rurais e a porção de área que se apresenta mais produtiva para as atividades agrícolas tradicionalmente praticadas na região.

De modo geral, as maiores vazões são verificadas em janeiro e fevereiro, período de maior pluviosidade, como já abordado no capítulo referente ao clima da bacia. A partir de abril, quando inicia o período menos chuvoso o nível fluviométrico reduz, sendo o mês de agosto o de menor vazão (Gráficos 4 e 5).

Estes gráficos exibem a comparação dos dados pluviométricos e de vazões na série histórica escolhida, em Eldorado e Sete Barras (locais de estudo e com postos de monitoramento do DAEE). A partir dos gráficos 4 e 5, nota-se que a vazão acompanha a pluviosidade, sendo os meses mais chuvosos os de maior vazão (janeiro, fevereiro e março), com exceção de junho (mês mais seco) para o município de Eldorado, cuja vazão foi a mais elevada $\left(576,22 \mathrm{~m}^{3} / \mathrm{s}\right)$. O mês de menor vazão foi agosto, para os dois postos de monitoramento, mês com menor índice pluviométrico.

Conforme dados do Daee (2006), em Eldorado a maior média registrada para a vazão na série histórica aqui investigada, foi de 1.116,00 $\mathrm{m}^{3} / \mathrm{s}$ em junho de 1983, já a menor foi de $90,88 \mathrm{~m}^{3} / \mathrm{s}$ em dezembro de 1985 . Na estação localizada em Sete Barras, durante este mesmo período, a maior média registrada foi de $1.240,30 \mathrm{~m}^{3} / \mathrm{s}$ em junho de 1983 e a menor de $94,51 \mathrm{~m}^{3} / \mathrm{s}$ em dezembro de 1985.

As maiores cheias observadas no Rio Ribeira de Iguape ocorreram nos anos de 1995, 1997 e 1998, sendo que a de 1997 foi a maior delas, em termos de vazão máxima. Com relação ao volume de cheias, a enchente ocorrida em 1983 foi a maior (ano com maior índicie pluviométrico, como abordado no capítulo referente ao Clima), atingindo um volume da ordem de 10 bilhões de $\mathrm{m}^{3}$ (DAEE, 1999). No ano de 1983 foi detectada a maior vazão 
do Rio Ribeira de Iguape para a base de Eldorado $\left(530,00 \mathrm{~m}^{3} / \mathrm{s}\right)$ e de Sete Barras $(587,16$ $\left.\mathrm{m}^{3} / \mathrm{s}\right)$.

Conforme Cetec (1999), nos últimos anos devido ao fenômeno EL NINÕ, os índices pluviométricos e fluviométricos elevados foram registrados entre maio e começo de junho.

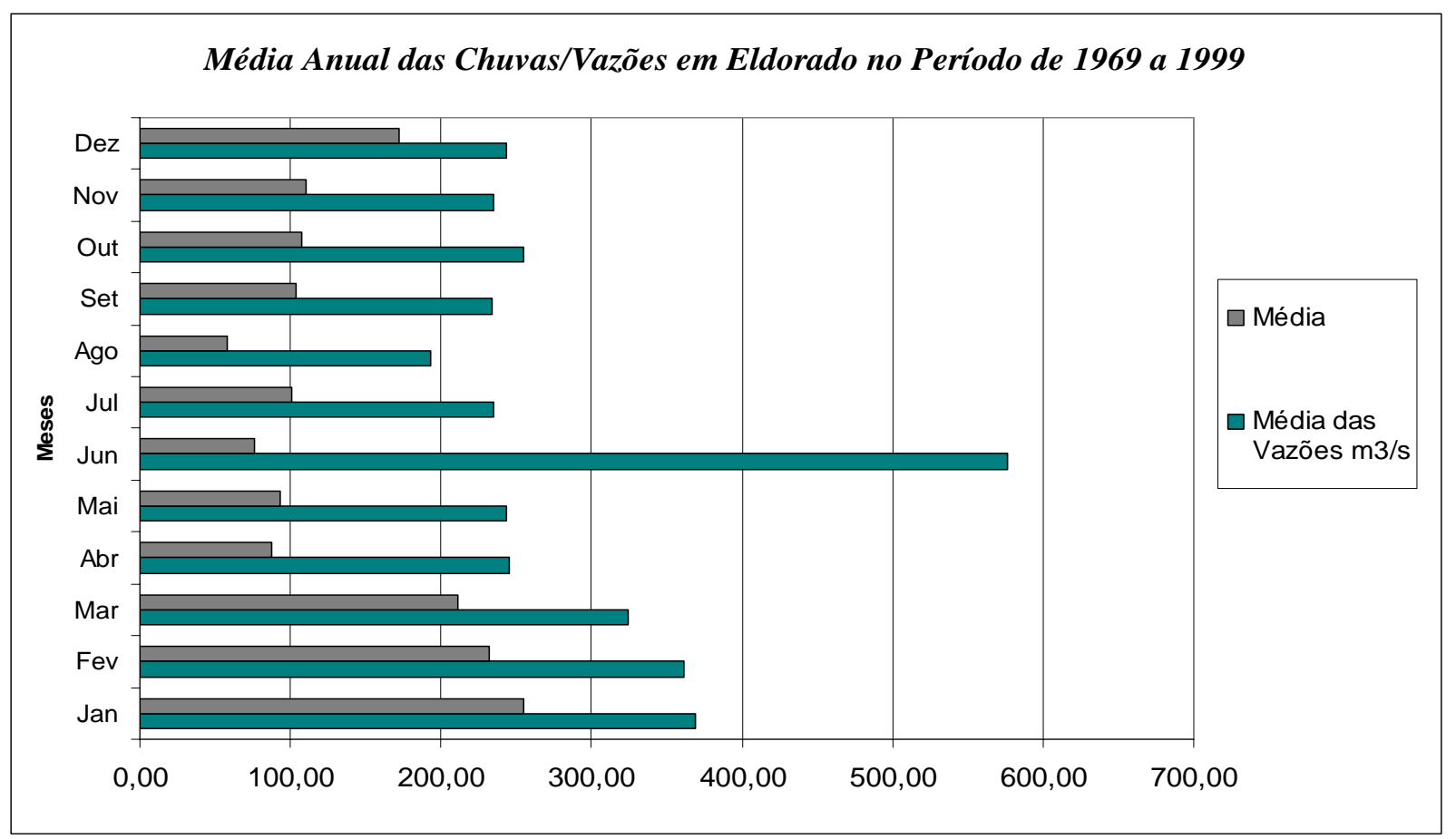

Gráfico 4 - Média anual das chuvas mm (cinza) e vazões m³/s (verde) em Eldorado no período histórico de 1969 a 1999

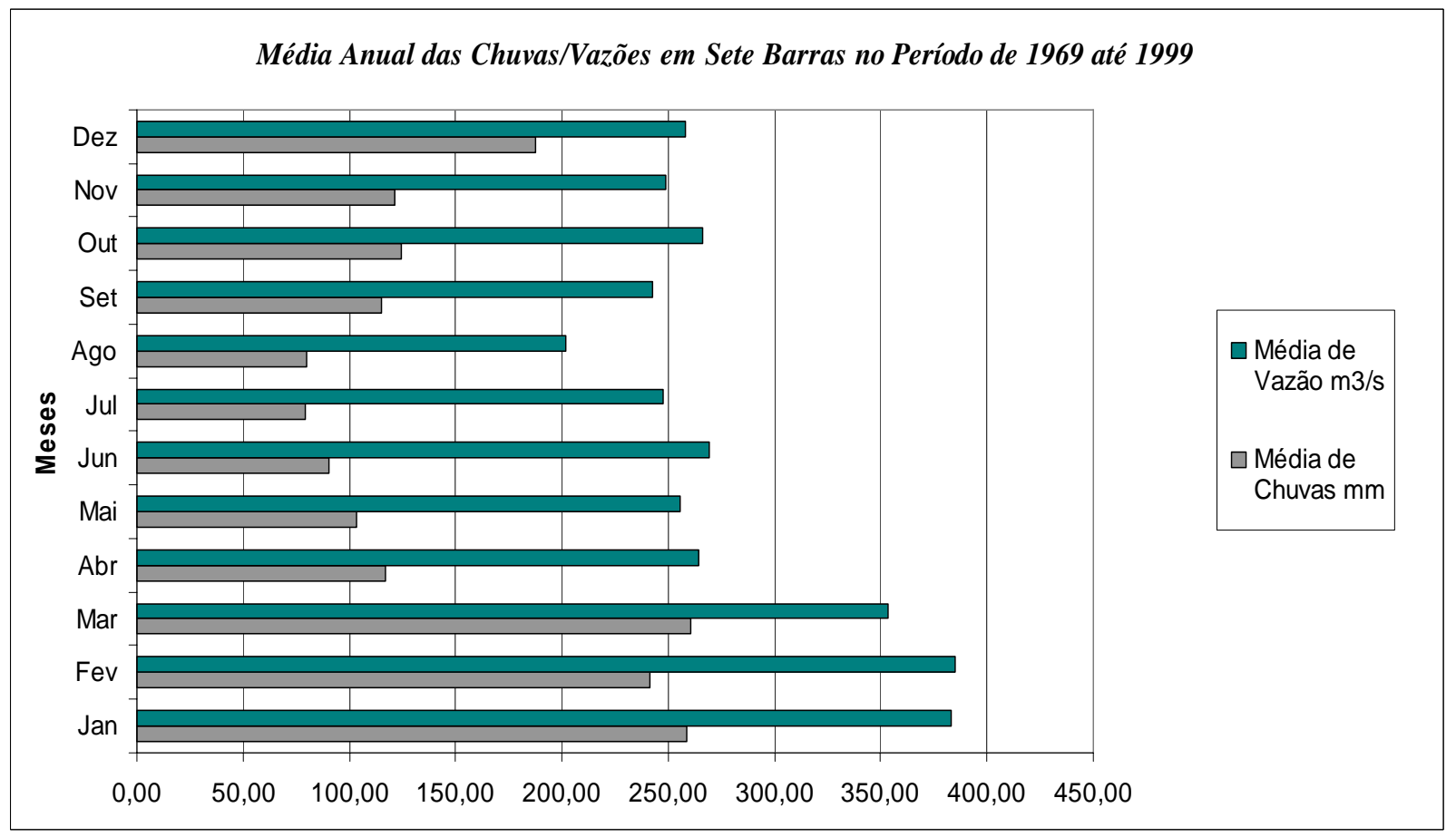

Gráfico 5 - Média anual das chuvas mm (cinza) e vazões m³/s (verde) em Sete Barras no período histórico de 1969 a 1999 


\section{REVISÃo BIBLIOGRÁFICA}

\subsection{VALE DO RibEIRA}

\subsubsection{Histórico da mineração no Alto Vale do Ribeira}

Segundo Daitx (1996) apud Moraes (1997), não se tem registros precisos sobre a época em que teria sido descoberta esta província mineral, mas sabe-se que em 1890 os veeiros do Morro do Chumbo já eram conhecidos há mais de cem anos remontando, pelo menos, a sua descoberta ao final do século XVIII.

A primeira jazida de $\mathrm{Pb}$ explorada economicamente foi a Mina Furnas (depósito tipo Panelas), manifestada em 1918 e cuja lavra foi iniciada por volta de 1919. Esta jazida localiza-se nas escarpas da Serra de Paranapiacaba às margens do ribeirão homônimo e seu minério (galena argentífera) era exportado para a Espanha. Esta mina produziu até 1968 entre 7.000 a 8.000 t de Pb (MELCHER, 1968 apud MORAES, 1997).

Em 1934 a Companhia de Mineração Iporanga instalou a primeira usina metalúrgica para $\mathrm{Pb}$ próximo as minas do Morro do Chumbo e Espírito Santo, atingindo uma produção de apenas 5 t do metal, sendo em seguida desativada (TESSLER, 2001).

Em 1935 iniciaram-se as pesquisas na Mina Panelas (depósito do tipo Panelas), sendo que sua explotação ocorreu em 1938 com a produção intermitente até 1946 e contínua de 1947 ao final da década de 80, quando foi considerada exaurida. Esta jazida localiza-se na margem direita do Rio Ribeira de Iguape, a jusante da cidade de AdrianópolisPR. De acordo com Moraes (1997), a mineralização da Mina Panelas (hospedada em rochas carbonáticas) é composta, principalmente, por galena, pirrotita e pirita, com menor participação de esfalerita e calcopirita. Esta jazida foi responsável por cerca de $55 \%$ da produção de $\mathrm{Pb}$ do Vale do Ribeira até o ano de 1985. Foram extraídos da Mina Panelas, aproximadamente, 1.330.000 t de minério com teor médio de 6,9\% de $\mathrm{Pb}$.

A descoberta da jazida do Rocha (depósito do tipo Panelas) ocorreu por volta de 1939, tendo sua explotação efetiva iniciada em 1956. Esta jazida esta localizada na bacia do ribeirão homônimo, afluente da margem direita do Rio Ribeira de Iguape, à montante da cidade de Adrianópolis-PR e Ribeira-SP (MORAES, 1997). Os filões encontrados nesta jazida apresentam, principalmente, galena e pirita, com pequena participação de calcopirita e esfalerita, sendo a ganga composta por dolomita e calcita, com pouco quartzo e rara fluorita. Extraiu-se desta mina, aproximadamente, 685.000 t de minério com teor médio de $6,2 \%$ de $\mathrm{Pb}$. A partir de 1980 , o minério proveniente desta mina foi beneficiado pela 
empresa Rocha Comércio e Exploração de Minério Ltda, por flotação, acarretando em aumento na produção.

Em 1943, iniciou-se a instalação no Vale do Ribeira, da empresa Plumbum S/A Indústria Brasileira de Mineração, na área da Mina Panelas, que entrou em operação em 1945. Todo o minério de $\mathrm{Pb}$ produzido no Vale do Ribeira a partir de 1945 foi refinado pela Plumbum até o ano de 1995, quando esta foi fechada. A viabilidade do aproveitamento econômico dos depósitos de $\mathrm{Pb}$ do Vale do Ribeira esteve intimamente ligada à proximidade desta empresa.

No ano de 1952 foi descoberto o jazimento da área do Paqueiro e em 1969 iniciou-se a operação da mina de Barrinha. O depósito da Mina Perau foi descoberto em 1974 e em 1975 iniciaram-se as atividades nesta mina.

A jazida da Mina Perau localiza-se às margens do rio homônimo, afluente do Ribeirão Grande que, por sua vez, deságua no Rio Ribeira a jusante da cidade de Adrianópolis-PR. Esta jazida é constituída por três níveis mineralizados denominados de cupríferos, sulfetados maciços e baritíferos, formando corpos mineralizados com diversas geometrias e composições químico-mineralógicas. Este minério é constituído por galena, esfalerita, pirita e, ocasionalmente, calcopirita disseminados na ganga composta por barita, calcita, dolomita, tremolita e quartzo. Segundo Moraes (1997), de 1974 a 1986 foram extraídos na Mina Perau, aproximadamente, 200.000 t de minério com teor médio de 6,13\% de $\mathrm{Pb}$ e $67 \mathrm{~g} / \mathrm{t}$ de $\mathrm{Ag}$.

Novos depósitos foram identificados na década de 80, tais como: do Araçazeiro, do Perau-SW e do Canoas. A jazida de Canoas iniciou sua operação em 1988 e foi paralisada em 1995, este depósito é do tipo Perau. A jazida de Canoas está localizada nas cabeceiras do rio homônimo, sendo os minerais de minério compostos por pirita, galena e esfalerita, com participação subordinada de calcopirita, pirrotita, marcassita, tetraedrita-tennantita, rutilo e titanita. Segundo Moraes (1997), extraiu-se desta mina entre 1988 a 1995, aproximadamente, 343.000 t de minério com teores de 2,8\% de $\mathrm{Pb}, 2,6 \%$ de $\mathrm{Zn}$ e $61 \mathrm{~g} / \mathrm{t}$ de $\mathrm{Ag}$.

Conforme Moraes (1997), a participação da produção mineral de $\mathrm{Pb}$ das minas situadas no Vale do Ribeira oscilava, no inicio da década de 80, entre 25 a 35\% do total da produção nacional. Segundo o Anuário Mineral do Departamento Nacional de Produção Mineral - DNPM (1986) apud Tessler (2001), a produção anual total de Pb metálico produzido no Vale do Ribeira, no ano de 1985, foi de $7.616 \mathrm{t}$.

Conforme Corsi (1999), a produção de $\mathrm{Pb}$, Zn e Ag atingiram por volta de 3.000.000t, no período de 1919 a 1995, procedentes de nove minas, das quais seis estão localizadas no 
Estado do Paraná (Panelas, Rocha, Barrinha, Perau, Canoas e Paqueiro) e três no Estado de São Paulo (Furnas, Lajeado e Espírito Santo).

Em 1990, a produção de Pb sofreu forte redução em decorrência do esgotamento e fechamento de algumas minas do Vale do Ribeira, tendo a usina pertencente a Plumbum operado até o final do ano de 1995, principalmente com minérios provenientes dos EUA, Peru, Argentina, Bolívia, Chile e Colômbia.

\subsubsection{Impactos causados pelas atividades de mineração}

As condições de mineração nesta região foram quase sempre rudimentares, não havendo controle sobre os impactos ambientais por elas gerados durante sua fase extrativa. A empresa Plumbum S/A Indústria Brasileira de Mineração, lançou diretamente no Rio Ribeira de Iguape, por aproximadamente 40 anos, os resíduos provenientes do tratamento do minério (rejeito do concentrado e escória de alto forno). Conforme Cetesb (1988) apud Cassiano (2001), aproximadamente 5,5 t/mês de elementos tóxicos (As, Cd, Pb, Cu, Cr e $\mathrm{Zn)}$ foram lançados no rio.

A partir de 1991, foi proibido o lançamento direto destes resíduos no Rio Ribeira de Iguape, com isso os rejeitos do concentrado passaram a ser depositados em dois tanques de decantação com capacidade individual de cerca de $80.000 \mathrm{~m}^{3}$ (CASSIANO, 2001). Conforme esta mesma autora, estes rejeitos possuem volume estimado de $300.000 \mathrm{t}$ e encontram-se, hoje, depositados diretamente sobre o solo nas proximidades do Rio Ribeira de Iguape.

Os resíduos provenientes da fundição do minério (escória) foram depositados na forma de pilhas, diretamente sobre o solo, sem qualquer tratamento prévio, nas proximidades da área pertencente a Plumbum, em Adrianópolis (PR).

Devido a este histórico, numerosos trabalhos foram desenvolvidos na Bacia do Rio Ribeira de Iguape, com o intuito de avaliar os efeitos tóxicos gerados neste sistema aquático. A seguir será apresentado, resumidamente um histórico dos trabalhos ambientais desenvolvidos neste rio.

Segundo Cetesb (1986), foram detectadas concentrações de $\mathrm{Pb}$ nas águas do Ribeirão do Rocha em níveis superiores a 730 vezes ao limite máximo recomendado para a preservação da vida aquática, além de teores de $2.560 \mathrm{mg} / \mathrm{kg}$ deste mesmo metal nos sedimentos de corrente desta mesma drenagem, considerando desta forma o ambiente como altamente poluído.

Tessler et al. (1987), constataram na região do sistema estuarino lagunar IguapeCananéia, a presença de sedimentos pelíticos com concentrações de metais que variaram 
de 1,4 a 105 ppm para o Zn, de 0,30 a 246,8 ppm para o $\mathrm{Pb}$ e de 0,05 a 292,4 ppm para o $\mathrm{Cu}$. Estes autores consideram o Rio Ribeira de Iguape como fonte destes sedimentos finos e, como provável responsável pela contaminação destes, a empresa mineradora situada no Alto Vale do Ribeira.

Conforme Eysink et al. (1988), o Ribeirão do Rocha localizado na área de influência da mina do Rocha, foi considerado um dos pontos mais críticos de contaminação dos sedimentos. Segundo estes autores, as minerações de $\mathrm{Pb}, \mathrm{Ag}$ e $\mathrm{Zn}$, a céu aberto e minerações subterrâneas, bem como as usinas de beneficiamento do Alto Vale, foram consideradas as principais fontes de contaminação para todo o sistema fluvial, bem como para o sistema costeiro, em especial o sistema Iguape-Cananéia.

Moraes (1997) comprova a origem dos metais a partir das minerações do Alto Vale do Ribeira, baseando-se na similaridade das assinaturas isotópicas de $\mathrm{Pb}$ dos sedimentos ativos de corrente e as do sistema costeiro Iguape-Cananéia, com as assinaturas isotópicas do $\mathrm{Pb}$ das galenas dos depósitos do tipo Panelas. Este autor estudou a distribuição dos metais $\mathrm{Pb}$, Cu e Zn nos sedimentos do Rio Ribeira de Iguape entre o Ribeirão do Rocha e o município de Iguape, junto à sua foz no Atlântico, num trecho de aproximadamente $350 \mathrm{~km}$, no intuito de avaliar os principais processos de transporte destes metais ao longo do rio. Segundo este pesquisador, os sedimentos estão fortemente contaminados por $\mathrm{Pb}$ no alto curso do rio (358 mg/kg), região de Adrianópolis (PR) e Ribeira (SP), decrescendo gradativamente $(52 \mathrm{mg} / \mathrm{kg}$ ) até a região de Itapeúna; neste trecho o rio apresenta-se fortemente encaixado, encachoeirado e, portanto, com elevado potencial de transporte. A partir de Itapeúna, município situado cerca de $50 \mathrm{~km}$ à jusante da última fonte de contaminação, os sedimentos voltam a se apresentar fortemente contaminados até a cidade de Registro (teores de 160-170 mg/kg). Este fato possivelmente encontra explicação na mudança do perfil energético do rio que, ao longo deste setor, apresenta locais propícios à deposição de sua carga sedimentar na forma de barras em pontal, meandros abandonados, ou em placeres, até alcançar a planície meandrante da região de Sete Barras - Registro. A partir daí os teores voltam, novamente a apresentar tendência de queda rumo à foz. Os resultados analíticos em amostras de água, sedimentos e sólidos em suspensão, associados às variações no perfil energético do rio, conduziram o autor ao entendimento de que os metais pesados presentes nos sedimentos são transportados principalmente pelos sólidos em suspensão que estão na água.

Corsi (1999) realizou estudo sobre a dispersão de metais pesados em águas e sedimentos de corrente a partir de mineralizações de $\mathrm{Pb}, \mathrm{Zn}$ e Ag, nas áreas de influência das minas de Canoas, Perau e Barrinha. Esta autora concluiu que a origem dos metais 
pesados nos sedimentos de corrente está vinculada à mineração do Alto Vale, e que o transporte destes ocorre preferencialmente através de materiais em suspensão na coluna d'água associadas aos óxidos e hidróxidos de ferro e manganês vinculados a carbonatos e matéria orgânica.

Cassiano (2001) caracterizou química, mineralógica e toxicologicamente os rejeitos provenientes da Mina do Rocha e propôs alternativas para minimizar a contaminação causada por este resíduo. Neste estudo, esta pesquisadora verificou que a forma de disposição destes resíduos era totalmente imprópria, propondo a retirada dos mesmos e sua colocação no interior de galerias subterrâneas (lugares protegidos da ação de processos erosivos).

Bosso e Enzweiler (2003) analisaram a solubilidade do $\mathrm{Pb}$ em amostras de solos superficiais, minerais e rejeitos de minério da área de Adrianópolis, região onde está instalada a Plumbum S/A. Este estudo determinou que o solo desta região está contaminado por $\mathrm{Pb}$. A maior concentração de $\mathrm{Pb}$ foi detectada na fração mais fina do solo, aumentando assim o risco de contaminação, uma vez que esta fração é mais facilmente suspensa e disponível para contaminação, seja por vias respiratórias ou via ingestão. Além do $\mathrm{Pb}$, também foram detectados altos teores de $\mathrm{Cd}$ e As, nas amostras de rejeito da Mina do Rocha. Estes autores concluíram que o $\mathrm{Pb}$ nos solos e rejeitos é significantemente solúvel, indicando que caso o solo fosse ingerido, poderia causar a absorção do mesmo pelo organismo.

Cunha (2003); Cunha et al. (2003), concluíram que as atividades decorrentes dos processos de refino dos minérios de $\mathrm{Pb}$ pela Plumbum S/A, afetaram todas as populações infantis residentes nos municípios do Alto Vale do Ribeira. As crianças residentes da Vila Mota e Capelinha foram as mais afetadas pela contaminação, onde se detectou valores acima de $100 \mathrm{mg} \mathrm{dL}^{-1}$ de $\mathrm{Pb}$ no sangue (aproximadamente 60\%) em relação as outras populações (aproximadamente 8\%). Estes autores, também verificaram que a água do Rio Ribeira de Iguape não é fonte de risco para a população, pois as concentrações dos metais estão abaixo do limite permitido pelo Conselho Nacional do Meio Ambiente (CONAMA). Por outro lado os solos superficiais coletados em Vila Mota e Capelinha foram considerados como fonte de risco à saúde, por exibirem elevados teores de metais pesados.

Sígolo et al. (2003), detectaram elevados teores de Pb, Cr e Zn nos resíduos de mineração (rejeito do concentrado da Mina do Rocha e Panelas e na escória) e classificaram estes como pertencentes aos resíduos Classe I, conforme norma da ABNT. Neste trabalho, os autores concluíram que o outro vetor contaminante dos sedimentos ativos 
de corrente é a escória acompanhada dos rejeitos de moagem da Mina do Rocha e de Panelas.

Moraes et al. (2004), comprovaram que a produção de minério nos depósitos do tipo Panelas foi responsável pela elevada concentração de metais pesados nos sedimentos de corrente da Bacia do Rio Ribeira de Iguape, sendo secundária a atuação dos depósitos do tipo Perau. Tal fato foi comprovado por análises isotópicas, as quais demonstraram que a composição isotópica dos sedimentos de corrente do Rio Ribeira de Iguape $(1,06$ < $206 \mathrm{~Pb} / 207 \mathrm{~Pb}<1,11$ ) está dentro dos limites da composição isotópica de $\mathrm{Pb}$ para os depósitos do tipo Panelas $(1,07<206 \mathrm{~Pb} / 207 \mathrm{~Pb}<1,16)$.

Estudos realizados por Figueiredo (2005), revelaram que embora as atividades de mineração e metalurgia realizadas no Vale do Ribeira tenham cessado em 1996, a população do Alto Vale ainda convive com várias fontes de contaminação, em especial a de $\mathrm{Pb}$. Segundo este pesquisador, os maiores níveis de exposição humana por $\mathrm{Pb}$ ocorrem nas comunidades localizadas nas proximidades da refinaria Plumbum (município de Adrianópolis). As emissões de metais pesados para atmosfera, durante décadas de funcionamento da refinaria e subseqüentemente deposição dos particulados, acarretaram na contaminação dos solos em áreas habitadas.

Recentemente foi realizado mapeamento geoquímico de baixa densidade, com base na amostragem e análise de sedimento ativo de corrente, cobrindo uma área de $19.000 \mathrm{~km}^{2}$, desde as cabeceiras do Rio Ribeira de Iguape até o município de Registro (LOPES Jr. et al., 2004; LOPES Jr., 2005). Tanto a dispersão física como a mobilidade química são importantes para a distribuição de $\mathrm{Pb}$ neste rio. Estes mapas, também mostram que a grande energia das águas, potencializadas durante a estação chuvosa, sustentam o processo de transporte dos sedimentos finos por centenas de quilômetros, desde as fontes antropogênicas (minas anteriormente ativas e hoje abandonadas) e naturais (solos da faixa Piririca, especificamente para o As) até a região de Registro e ao que tudo indica, também para a zona estuarina (Iguape/Cananéia).

Guimarães e Sígolo (2005) detectaram a presença de metais pesados em carapaças de uma espécie biomonitora no Rio Ribeira de Iguape. Indicando acumulação dos metais pesados lançados neste rio pela biota. Tais pesquisadores confirmam a necessidade da análise dos tecidos desta espécie biomonitora.

Resumidamente, as pesquisas realizadas no Vale do Ribeira demonstraram que a Bacia Hidrográfica do Rio Ribeira de Iguape foi afetada, em toda sua extensão, pelas atividades minerais e de refino realizadas no Alto Vale do Ribeira, em especial, nas áreas próximas das minas (principalmente as Mina do Rocha, Furnas, Panelas) e da refinaria 
Plumbum S/A. Estas pesquisas, como abordado neste capítulo, sugerem que os metais pesados foram e estão sendo transportados por sedimentos em suspensão, ao longo do Rio Ribeira de Iguape. Até o presente momento, não foi realizado estudo detalhado mostrando qual dos resíduos está contaminando o rio (rejeito do concentrado ou escória ou ambos) e se está ocorrendo depuração natural deste rio, conferindo assim mais um foco de investigação inédita para a presente tese.

\subsection{Metais Pesados}

Várias definições são encontradas na literatura para o termo "metal pesado", sendo que algumas destas baseiam-se na densidade atômica, outras no peso ou número atômico. Entretanto, a definição empregada com freqüência está relacionada com a saúde pública, onde os metais pesados são classificados como sendo elementos que apresentam efeitos adversos à saúde humana. Neste contexto, enquadram-se metais ou metalóides que estão associados com poluição e toxicidade, incluindo também, alguns elementos que são essenciais aos seres vivos, quando em baixas concentrações.

O termo "metal pesado" é empregado com freqüência para elementos como $\mathrm{Pb}, \mathrm{Cd}$, $\mathrm{Cr}, \mathrm{Cu}$, mercúrio-Hg, As, Ni, Zn entre outros. A toxicidade destes metais depende muito de sua concentração e biodisponibilidade, sendo está última fortemente ligada à forma química deste composto no ambiente investigado.

Os metais pesados diferenciam-se dos demais elementos, devido a sua tendência em formar ligações reversíveis com grande número de compostos e por não serem biodegradáveis, participando do ciclo ecobiológico global no qual a água tem papel principal (TOMAZELLI, 2003). Deste modo, estes elementos podem gerar alterações nas interações entre os parâmetros físicos, químicos e biológicos de um determinado ecossistema, devido as suas propriedades de persistência no ambiente, bioacumulação e biomagnificação na cadeia trófica, causando sérios problemas toxicológicos para os organismos vivos.

Os metais pesados são introduzidos no sistema aquático através da deposição atmosférica, intemperismo e erosão das rochas ou por fontes antropogênicas (efluentes industriais, resíduos de mineração, dentre outros), segundo Nurberg (1984) apud Molisani et al. (1999).

\subsubsection{Metais pesados e mineração}

Os metais pesados podem ser liberados naturalmente dos minérios contidos nas rochas por processos intempéricos ou erosivos, contudo, a atividade de mineração 
potencializa muito esta liberação, por retirar do equilíbrio geoquímico natural massas de material rico em tais elementos (SALOMONS, 1995).

Segundo Rybicka (1996), as atividades de mineração e processamento do minério causam problemas, geralmente irreversíveis, nos sistemas terrestres e aquáticos. Os efeitos mais sérios decorrentes de tais práticas são: 1) mudanças em sistemas hidrológicos; 2) transformações ocorrentes nos solos e corpos d'água superficiais; 3) contaminação dos solos e reservatórios d'água superficiais e 4) poluição atmosférica. Os impactos ambientais gerados pela mineração podem ser, tanto de escala regional como local.

A dispersão dos metais pesados das áreas mineralizadas até seu destino final como poluente segue a seguinte rota, de acordo com Salomons (1995): Crosta Terrestre (área mineralizada) $\Rightarrow$ Mineração $\Rightarrow$ Refino $\Rightarrow$ Uso na Sociedade Moderna $\Rightarrow$ Resíduos (superfície terrestre: locais de disposição de rejeitos, etc). Os depósitos de rejeitos e pilhas de estéril são os principais responsáveis pela dispersão dos metais pesados para o meio ambiente, por conterem tais elementos e por ficarem expostos à ação de agentes intempéricos.

Além dos rejeitos com elevado conteúdo de metais, as áreas de disposição de minérios e concentrados ou a própria área de lavra constituem áreas fontes destes elementos. A recuperação destas áreas fontes de contaminação exige um entendimento do comportamento específico dos metais com relação às condições locais (clima, mineralogia, geologia, pedologia, geoquímica, topografia e atividade biológica) que influenciam nos parâmetros físico-químicos $(\mathrm{pH}$, Eh, temperatura, condutividade e OD) reinantes e, conseqüentemente, nos processos de interação existentes onde estes elementos se encontram (LAROCQUE; RASMUSSEN, 1998). Dos elementos que ocorrem naturalmente, os que são considerados mais tóxicos para o meio ambiente são: $\mathrm{Pb}$, As, Cd e Hg.

Muitas vezes, nos depósitos de rejeitos pode ocorrer a denominada "drenagem ácida". Esta drenagem ocorre em depósitos minerais com predomínio de sulfetos de ferro (pirita, marcassita, pirrotita, calcopirita, etc) os quais em contato com oxigênio e água, liberam após diferentes reações químicas, ácido sulfúrico. Para a formação da drenagem ácida, as rochas residuais não devem ser portadoras de minerais primários carbonatados os quais atuam na neutralização da drenagem ácida, quando presentes.

\subsubsection{Metais pesados em sistemas aquáticos}

Os metais pesados adicionados ao sistema fluvial, por fontes naturais ou antrópicas, podem ser transportados de duas maneiras: como espécies dissolvidas na água ou 
associados às partículas sólidas transportadas pelo rio, sejam estas em suspensão ou arrastadas como parte da carga do leito do rio.

$\mathrm{Na}$ água, os metais podem estar presentes nas formas particulada (em suspensão ou sedimento de fundo), coloidal e dissolvida, sendo constantemente redistribuídos entre estas fases durante o transporte ( $\mathrm{SHI}$ et al., 1998), e dependendo de sua forma química, podem ser acumulados pelos organismos vivos.

Os sedimentos têm importante papel no transporte e acumulação de contaminantes e freqüentemente são empregados na determinação de fontes e formas de dispersão destes elementos em sistemas aquáticos (RULE, 1986 apud SANTOS et al., 2002).

Segundo Kenneshi (1995) apud Bahena-Manjarrez et al. (2002), os sedimentos em suspensão em ambientes fluviais, geralmente, são formados por: 1) minerais de argila; 2) óxido e hidróxido de ferro e manganês; 3) carbonatos; 4) substâncias orgânicas (ácidos húmicos) e 5) material biológico (algas, bactérias e plânctons). Estes sedimentos e os de fundo têm importante papel na quantidade de metais dissolvidos na coluna d'água, pois estes materiais podem capturar tais metais a partir de processos como: precipitação química, adsorção e reações de complexação.

O termo sorção é usado para fenômenos de absorção (assimilação no volume), adsorção (assimilação física, eletrostática ou química na superfície) e co-precipitação ou solução sólida, que nem sempre são facilmente distinguidos (MOORE; RAMAMOORTHY, 1984). O fenômeno de adsorção ocorre quando uma espécie (íon, átomo ou molécula sólida, líquida ou gasosa) é atraída e capturada pela superfície externa de uma partícula sólida através de forças físico-químicas. Essa captura promove a acumulação de materiais amorfos na superfície das partículas adsorventes, principalmente quando essas partículas possuem carga superficial negativa e elevada superfície específica, como os minerais de argila e matéria orgânica.

Segundo Bourg (1995), a complexação e precipitação dos metais pesados nos sedimentos ocorrem a partir dos seguintes fatores: A) oxidação de componentes reduzidos tais como ferro, manganês e sulfetos; B) redução de metais de alta valência pela interação com a matéria orgânica (selênio, prata); C) redução de sulfato para sulfeto ( $\mathrm{Fe}, \mathrm{Cu}, \mathrm{Ag}, \mathrm{Zn}$, $\mathrm{Hg}, \mathrm{Ni}$, As e selênio-Se, precipitam-se como sulfetos); D) reações tipo alcalina (estrôncio-Sr, manganês-Mn, ferro-Fe, $\mathrm{Zn}, \mathrm{Cd}$ e outros elementos são precipitados pelo aumento de $\mathrm{pH}$ usualmente causado pela interação com rochas alcalinas e sedimentos ou pela mistura com águas alcalinas); E) adsorção ou co-precipitação de íons metálicos com óxidos de Fe e Mn, argilas e particulados de matéria orgânica. 
Salomons e Stigliani (1995), demonstram que a complexação e precipitação dos metais pesados nos sedimentos dependem principalmente do: A) $\mathrm{pH}$; B) conteúdo de hidróxidos e óxidos de ferro e manganês; C) potencial de oxi-redução; D) propriedades superficiais; E) natureza e concentração de constituintes na fase aquosa; F) quantidade e razão de fluxo de solução com mudança direta do sistema aquático ou terrestre.

Os processos de co-precipitação e/ou adsorção dos metais ao longo dos rios podem ser considerados como uma atenuação natural da concentração de metais nas águas, embora abaixo de condições favoráveis os metais adsorvidos podem ser desorvidos e serem liberados em solução (KWONG et al., 1997). Segundo Cidu et al. (1997), apenas os processos naturais de atenuação não agem eficientemente no controle dos metais em áreas onde estes estejam sendo adsorvidos. Os processos de desorção são mais lentos que os de sorção, mas apesar disso, podem agir como uma fonte contaminante de longa duração, podendo exigir extensos períodos para a recuperação da água e do solo.

Desta forma, a concentração de metais pesados nas partículas sólidas (sedimentos em suspensão e sedimentos de fundo) não depende somente das fontes antrópicas e litogênicas, mas também de características texturais, conteúdo de matéria orgânica, composição mineralógica e ambiente deposicional do sedimento (PRESLEY et al., 1980 apud BaHEMA-MANJARREZ, 2002).

Os metais pesados não são permanentemente fixados nos sedimentos, podendo sofrer liberação para coluna d'água em decorrência de mudanças nas condições ambientais, tais como: pH, Eh (potencial redox) e presença de quelatos orgânicos. Segundo Kelly (1988), esta transferência dos metais que estão precipitados nos sedimentos para a coluna d'água pode ocorrer através de três formas: A) pela ciclagem biogeoquímica, B) por turbulência ou C) por liberação através da biota. O primeiro processo, segundo este autor é talvez o mais provável de ocorrer em águas profundas onde existem pronunciados ciclos redox, enquanto que, os dois últimos estão associados com as partes mais rasas de lagos e rios.

A forma de distribuição desses metais pesados no ambiente aquático é muito importante para efeito da toxicidade (HAKANSON; JANSSON, 1983). Esses metais podem ser mais ou menos móveis nestes sistemas, dependendo da razão entre a fração dissolvida e precipitada. Conforme Baudo et al. (1990); Salomons e Stigliani (1995), o metal pesado na forma dissolvida é considerado mais móvel e mais biodisponível para os organismos que a forma particulada. 
O modo como o metal está presente na água é chamado de especiação química, sendo esta dependente de fatores físico-químicos da água como salinidade, $\mathrm{pH}, \mathrm{Eh}$, concentrações e características dos ligantes (complexos aniônicos).

De um modo geral, a solubilidade de muitos metais aumenta com o decréscimo do $\mathrm{pH}$, havendo relação direta entre este e a solubilidade, ou seja, quanto mais ácido for o $\mathrm{pH}$ do meio, maior será a mobilidade destes elementos. Com isso, metais retidos nos sedimentos migram para a coluna d'água, em decorrência do abaixamento do $\mathrm{pH}$, expressando assim a toxicidade destes poluentes (SALOM NOS; STIGLIANI, 1995).

Devido a todo esse processo dinâmico de transporte e redistribuição dos metais nas diferentes fases, concentrações aparentemente baixas na coluna d'água e nos sedimentos, podem ser potencialmente disponíveis para acúmulo pelos organismos, tornando-se eventualmente tóxicas. Assim sendo, em pesquisas para determinação de contaminação por metais pesados em sistemas aquáticos, é necessário analisar amostras d'água (teores de metais dissolvidos), sedimento em suspensão, sedimento de fundo e biota.

\subsection{BIOMONITORES}

As análises de água e sedimentos são importantes para avaliação da contaminação ambiental por metais pesados em sistemas fluviais, mas não fornecem dados reais sobre a disponibilidade dos elementos aos organismos aquáticos (TOMAZELLI, 2003). Desta forma, é necessário correlacionar os poluentes químicos, o ambiente em que estes poluentes são liberados e a biota presente na área de estudo.

O emprego da biota em pesquisas de monitoramento ambiental data da década de 60 e foi primeiramente utilizado por Folsom et al. (1963) apud Tomazelli (2003), na tentativa de quantificar a contaminação das águas da Califórnia por radionuclideos. Ainda segundo Tomazelli (2003), no final da década de 60 e início dos anos 70, outros pesquisadores iniciaram estudos sobre a possibilidade da utilização de organismos para monitorar contaminantes conservativos em ecossistemas aquáticos. Atualmente a biota tornou-se uma importante ferramenta em programas de monitoramento ambiental, uma vez que a biodisponibilidade é medida diretamente, sem suposições, como ocorre em outros métodos analíticos.

A biodisponibilidade de um elemento químico é a medida do potencial que o mesmo tem para ser absorvido pelos seres vivos, estando diretamente relacionado com a forma química deste composto no meio ambiente (ROON, 1999). A maior parte destes elementos pode ser transportado basicamente de dois modos: como espécies dissolvidas na água e/ou associados às partículas sólidas. 
As espécies que acumulam metais pesados ou outras substâncias em seus tecidos e por esta razão podem ser usadas no monitoramento da biodisponibilidade destes compostos em um ambiente particular recebem o nome de biomonitores (WAGNER; BOMAN, 2003). Os biomonitores fornecem medidas de tempo-integral dos níveis de biodisponibilidade de uma substância, aspecto que faz com que estas análises sejam superiores se comparadas com as realizadas em amostras de água e sedimentos, que podem variar extensamente devido à pequena variação temporal.

De acordo com Wagner e Boman (2003), as características essenciais requeridas a uma espécie biomonitora incluem: capacidade de acumular poluentes, ser sedentária e representativa da área pesquisada, abundante, exibir tempo de vida longo, apresentar um razoável tamanho para produzir tecido suficiente para análise, ser de fácil coleta e devem apresentar alto fator de concentração para os elementos investigados. Em decorrência das características descritas acima, os melhores biomonitores de metais pesados empregados em ambientes aquáticos tem sido as macroalgas e moluscos bivalves.

\subsubsection{Moluscos bivalves}

Os moluscos bivalves têm importância ecológica relevante pela posição que ocupam no primeiro nível trófico da cadeia alimentar, alimentando-se, principalmente, de fitoplâncton em processo de filtração constante (conhecidos comumente como indivíduos filtradores). Quando ingeridos podem oferecer risco à saúde pública por serem organismos filtradores e bioacumuladores de poluentes químicos e biológicos. As concentrações de metais pesados para diferentes espécies de biota e para o homem podem tornar-se altamente tóxicas com os processos de bioacumulação e biomagnificação (aumento progressivo na concentração dos elementos contaminantes e tóxicos ao longo da cadeia alimentar).

Moluscos bivalves têm sido extensivamente usados na avaliação de metais pesados em ambientes aquáticos, por fornecerem informações exatas e integradas sobre o impacto ambiental e biodisponibilidade de tais elementos (PHILLIPS, 1977; TESSIER et al., 1984; ABAYCHI; MUSTAFÁ, 1988; BILOS et al., 1998).

$\mathrm{Na}$ área de pesquisa enfocada por esta tese foram encontrados moluscos bivalves, desde Iporanga até Iguape. Estes moluscos foram classificados como pertencentes ao filo Mollusca, classe Bivalvia, ordem Veneroida, família Corbiculidae e espécie Corbicula fluminea. Devido ao histórico de contaminação do Rio Ribeira de Iguape por atividades minerais e em decorrência da existência em grande parte da bacia hidrográfica estudada deste bivalve, optou-se pela utilização destes organismos na determinação da biodisponibilidade dos metais pesados presentes no rio. 


\subsubsection{Corbicula fluminea}

Vários pesquisadores vêm utilizando a Corbicula fluminea (Figura 3), bivalve de água doce, como biomonitor de metais pesados em ambientes fluviais (GRANEY Jr. et al. 1984; TESSIER et al., 1984; BELANGER et al., 1990; McCAULOU et al., 1994; TOMAZELLI, 2003).

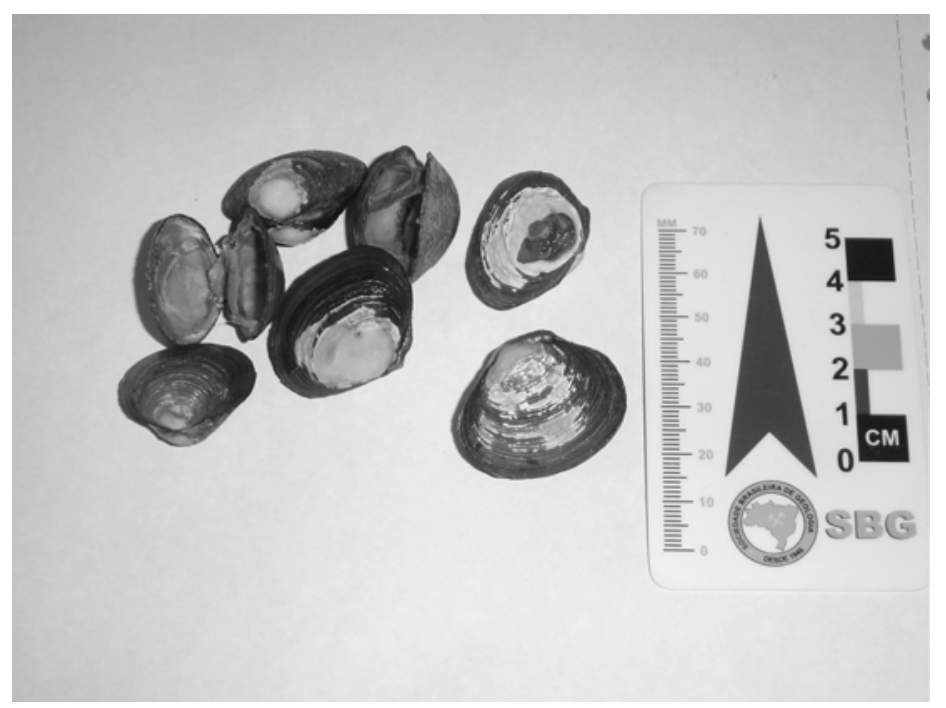

Figura 3 - Moluscos bivalves da espécie Corbicula fluminea

Segundo Graney Jr. et al. (1984), este molusco é adequada como organismo biomonitor, em decorrência do seu estilo de vida ser bentônico e apresentar distribuição cosmopolita, assegurando, desta forma uma representatividade da área analisada.

As espécies de Corbicula fluminea vivem, principalmente, enterradas em fundos lodosos, argilosos ou areno-lodosos e seu tamanho é de até $2,5 \mathrm{~cm}$ de comprimento (JACOMINI, 2002). Alimentam-se de fitoplâncton e são empregados como monitores biológicos (biomonitores) devido as suas características próprias e modo de vida (sedentarismo, por viverem em ambiente de água doce enterrados em substratos lodosos filtrando grandes quantidades de água). A grande maioria dos bivalves de água doce permanece com as valvas abertas durante grande parte do dia.

Segundo Mccaulou et al. (1994), em organismos filtradores-alimentadores, como é o caso da Corbicula fluminea, o acúmulo de metais pesados ocorre no estado solúvel via respiração (bioconcentração) e via ingestão de material particulado (bioacumulação). Moluscos filtradores-alimentadores podem ser particularmente bons biomonitores, pois refletem os contaminantes que estão disponíveis em três diferentes vias: material biótico particulado, íons em solução disponíveis na coluna d'água e íons associados com sedimento. 
A Corbicula fluminea vem, nos últimos anos, povoando de forma assustadora os principais mananciais da região Centro-Sul brasileira (essa espécie foi encontrada pela primeira vez no Rio Grande do Sul, na década de 70). 


\section{MATERiAis E Métodos}

Para atingir os objetivos propostos foram coletadas e analisadas amostras de: 1) resíduos da mineração (rejeitos do beneficiamento do minério), 2) resíduos da metalurgia (escórias); 3) sedimentos (sedimentos em bancos de areia, sedimentos ativos de corrente, sedimentos em suspensão e sedimentos estuarinos) e 4) biomonitor (espécie de bivalve molusco Asiático da espécie Corbicula fluminea). Os trabalhos de campo foram realizados no Alto Vale do Ribeira (mina do Rocha e de Panelas, ambas no Estado do Paraná) e no Rio Ribeira de Iguape (área compreendendo os municípios de Iporanga, Eldorado, Sete Barras, Juquiá, Registro e Iguape - todos no Estado de São Paulo).

\subsection{RESídUOS dA MINERAÇÃO}

Como já mencionado, a atividade mineral (extração, beneficiamento e metalurgia) realizada no Vale do Ribeira, foi paralisada em meados de 1995 em virtude da exaustão das reservas e dificuldades tecnológicas. Ainda hoje, permanecem nas áreas das antigas minas e nos locais onde estavam instaladas as plantas de concentração do minério e a metalurgia, pilhas de estéril e de resíduos (resíduos da atividade de mineração e da metalurgia).

Desta forma, primeiramente foi realizado trabalho de campo, em fevereiro de 2002, para reconhecimento das áreas onde atuaram as antigas minas do Vale do Ribeira e as plantas de concentração e metalurgia. Algumas minas não foram visitadas devido à dificuldade de acesso, tais como: Furnas, Barrinha, Paqueiro, Canoas e Lajeado.

Nesta investigação foram delimitadas duas áreas de pesquisa, mina do Rocha (localizada no município de Cerro Azul) e mina de Panelas (localizada no município de Adrianópolis), ambas no Estado do Paraná (Figura 4). Estas áreas foram escolhidas devido à presença de resíduos do beneficiamento do minério (rejeitos resultantes do processo de concentração do minério) depositados na forma de pilhas diretamente sobre o solo sem qualquer tratamento prévio. Nas outras minas visitadas foram encontradas apenas pilhas de estéril e galerias abandonadas, justificando assim a escolha destas áreas.

Neste documento estes rejeitos serão tratados separadamente como: Rejeitos do Concentrado da Mina do Rocha e Rejeitos do Concentrado da Plumbum.

Os rejeitos do concentrado da Mina do Rocha representam o minério proveniente da mina homônima que foi beneficiado pela empresa Rocha Comércio e Exploração de Minério Ltda, sediada nesta mesma área. Este beneficiamento compreendeu na cominuição até a fração 100 mesh e posterior concentração por flotação, do minério com paragênese principal 
formada por galena, pirita, esfalerita, calcopirita e sulfossais de Sb/As, disposto na forma de veios encaixados em metadolomitos (minério do tipo Panelas).

Os rejeitos do concentrado da Plumbum representam todos os minérios de $\mathrm{Pb}$ produzidos no Vale do Ribeira a partir de 1945 (tanto os do tipo Panelas como os do tipo Perau), com exceção do minério da Mina do Rocha. É verificado na literatura, que nos últimos anos de atuação da Plumbum, ela beneficiou, principalmente os minérios da Mina de Canoas (tipo Perau).

Desta forma entende-se que estes dois resíduos são representativos dos minérios tratados e explotados no Vale do Ribeira, sendo o rejeito do Rocha representativo do minério encontrado nesta mina e o da Plumbum representativo de todas as minas do Vale.

Os resultados obtidos para estes resíduos foram tratados estatisticamente pelo Centro de Estatística Aplicada (CEA) do Instituto de Matemática (IME) da USP. Para indicação do grau de contaminação e periculosidade destes resíduos foram empregadas as normas técnicas ABNT-NBR 10.005 (ABNT, 1987a, b e c), para resíduos sólidos. 


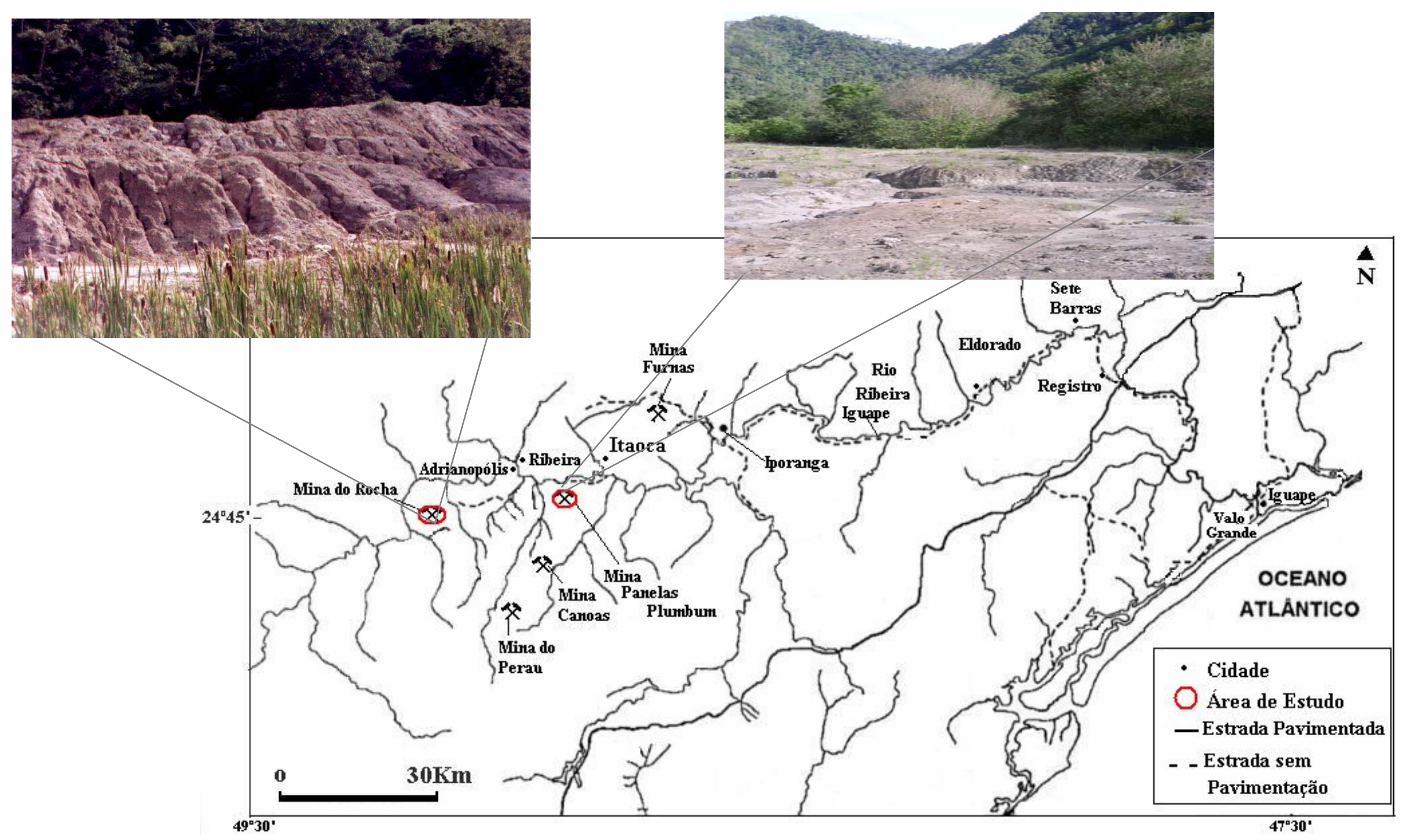

Figura 4 - Mapa de localização das minas do alto Vale do Ribeira- rejeitos do concentrado da mina do Rocha e da Plumbum 


\subsubsection{Rejeitos do concentrado da Mina do Rocha}

Os rejeitos resultantes da concentração do minério detectados na Mina do Rocha foram dispostos na forma de pilha, durante o período de 1991 a 1995, sendo que a última data compreende o término das atividades desta mina (Figura 5). Esta pilha, na época da coleta, encontrava-se depositada diretamente sobre o solo às margens do ribeirão do Rocha e apresentava um volume de aproximadamente $3.000 \mathrm{~m}^{3}$ (Figura 6). Sabe-se que atualmente este rejeito foi removido desta área para o interior de uma cava.

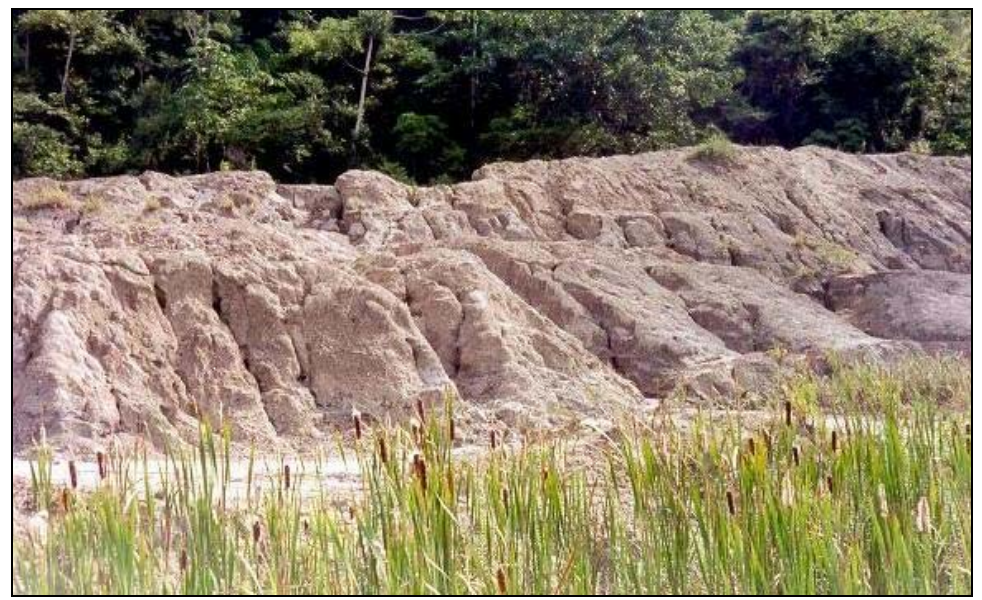

Figura 5 - Pilha de rejeito do concentrado da mina do Rocha

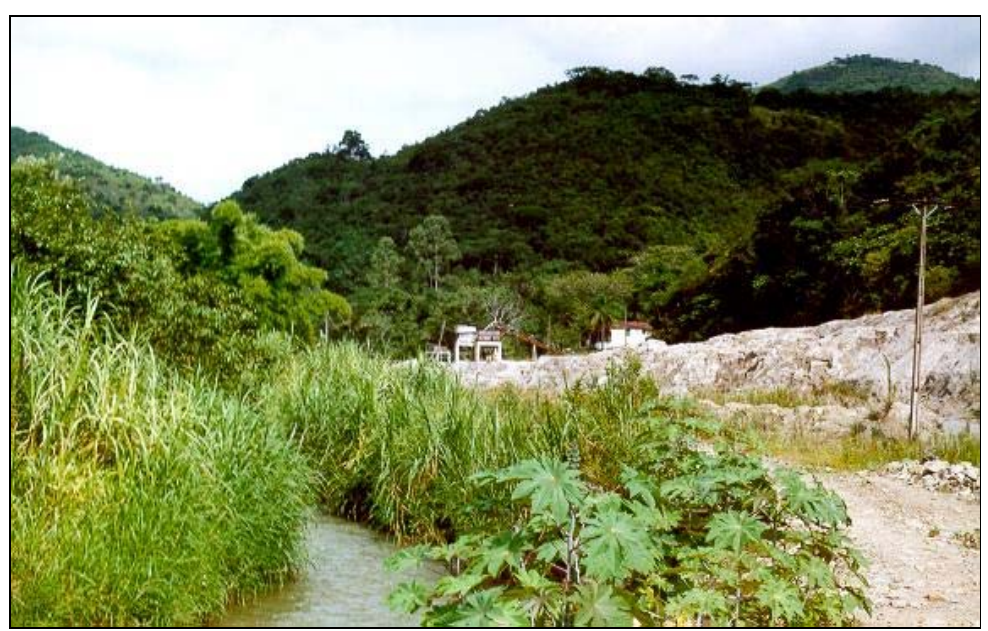

Figura 6 - Rejeito da mina do Rocha depositado às margens do ribeirão homônimo

Em 2002 foi realizada sondagem de $3,40 \mathrm{~m}$ de profundidade com trado manual modelo Holandês, visando caracterizar este rejeito para posterior comparação com os elementos detectados nos diversos tipos de sedimentos aqui investigados. Esta sondagem forneceu 11 amostras, individualizadas de acordo com critérios de campo (cor, 
granulometria, grau de alteração), com espessuras variáveis entre 20 e $60 \mathrm{~cm}$, as quais foram armazenadas em sacos de polietileno e foram denominadas de MR01 até MR11.

Estas amostras foram submetidas à secagem a $40^{\circ} \mathrm{C}$. Após obterem peso constante foram destorroadas, homogeneizadas e quarteadas (pelo método de pilhas alongadas) para fornecimento de alíquotas necessárias às diversas caracterizações e análises laboratoriais.

Tal investigação envolveu outros pesquisadores, sendo que cada um desenvolveu análises distintas visando caracterizar todo o perfil, os procedimentos e resultados obtidos para os outros tratamentos encontram-se em: Franchi et al.; (2002); Leal et al. (2002); Leal (2002) e Franchi (2004).

\section{Caracterização das Amostras}

1. Análises Químicas

A análise química total teve por objetivo a detecção dos elementos maiores, menores e traços presentes na amostra. Este estudo foi realizado pelo método de fluorescência de raios-X (FRX) no Laboratório de Caracterização Tecnológica (LCT) - Departamento de Engenharia de Minas e de Petróleo - POLI - USP. O tratamento das amostras envolveu: moagem em panela de ágata (granulometria na faixa de 325 mesh) e preparo do pó em pastilhas prensadas. As pastilhas foram analisadas em Espectrômetro de Fluorescência Raios X modelo Axios Advantage da Panalytical. O software empregado foi "standardless" (IQ+ versão 4.0), que trabalha com parâmetros fundamentais para cálculos de teores, overlaps e sensitividade instrumental.

\section{Análises em Microscópio Eletrônico de Varredura}

Esta análise foi executada no Laboratório de Microscopia Eletrônica do IGc da USP, tendo por finalidade o estudo da morfologia dos grãos e detecção dos metais pesados por análise química qualitativa. As amostras foram preparadas em "stubs" e recobertas com carbono, sendo posteriormente analisadas em Microscópio Eletrônico de Varredura LEO 440I acoplado com espectrômetro de dispersão de energia de raios X com detector de estado sólido tipo Si (Li) marca Oxford. Nesta investigação foram obtidos espectrogramas e imagens de elétrons secundários e retro-espalhados.

\subsubsection{Rejeitos do concentrado da Plumbum}

Nas proximidades do terreno pertencente à antiga empresa Plumbum S/A, encontram-se depositados rejeitos provenientes do beneficiamento do minério, entre a margem esquerda da estrada que acessa a unidade industrial (Plumbum) a partir de Adrianópolis (PR) e a margem direita do rio Ribeira de Iguape, distando cerca de $50 \mathrm{~m}$ deste 
último. Segundo Franchi (2004), o volume de rejeito estimado para a pilha depositada nesta área é de $89.000 \mathrm{~m}^{3}$ (Figura 7).

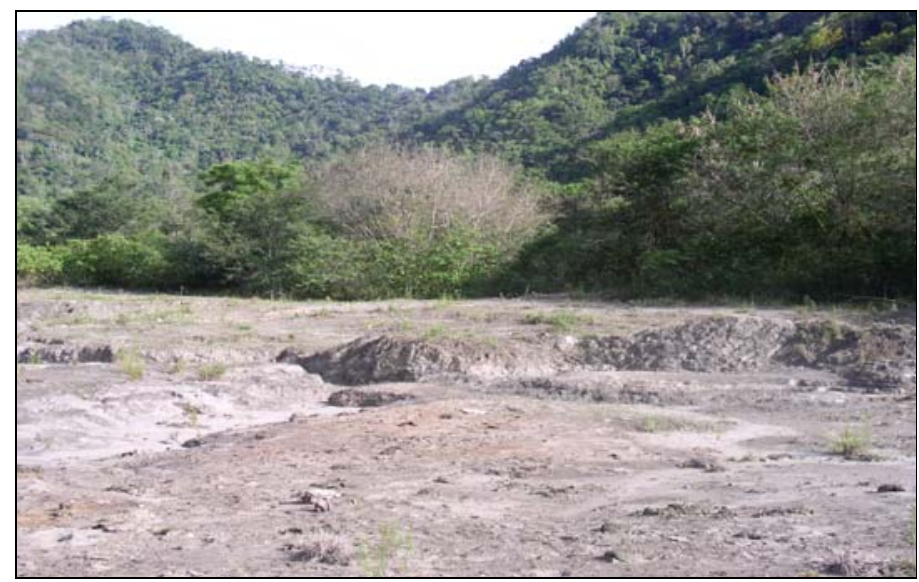

Figura 7 - Rejeitos do concentrado da Plumbum depositados na área da mina de Panelas

Este depósito foi investigado através de nove sondagens efetuadas com trado manual modelo Holandês, em duas missões de campo (março de 2002 e setembro de 2003). A profundidade alcançada em cada sondagem variou em função do grau de compactação do material atravessado (máximo de 4,5 m). Os perfis foram denominados de RP-1 a RP-9 e foram sub-amostrados no campo de 20 em $20 \mathrm{~cm}$, resultando em aproximadamente, 15 a 20 amostras por sondagem.

Conforme Franchi (2004), a disposição destes rejeitos ocorreu, inicialmente, sob a forma de polpa, originando uma superfície na bacia nivelada com a superfície original da planície de inundação ("patamar 0" da figura 8). A colmatação da bacia ocasionou na construção de diques marginais para aumento da capacidade de armazenamento, gerando o "patamar 4" (atingindo até $4 \mathrm{~m}$ ) indicado na figura 8, e permitindo a continuidade do processo de condução dos rejeitos à bacia sob a forma de polpa. Formou-se então outra superfície, topograficamente $2 \mathrm{~m}$ acima da superfície original, designada de "patamar 2", o qual perfaz cerca de $60 \%$ do total da área exposta do depósito, e provavelmente representou o limite da operação de transporte dos rejeitos. Pequenos montes de rejeito encontram-se espalhados, apenas sobre esta superfície, evidenciando que a descarga na bacia passou a ser feita através de veículos basculantes. 


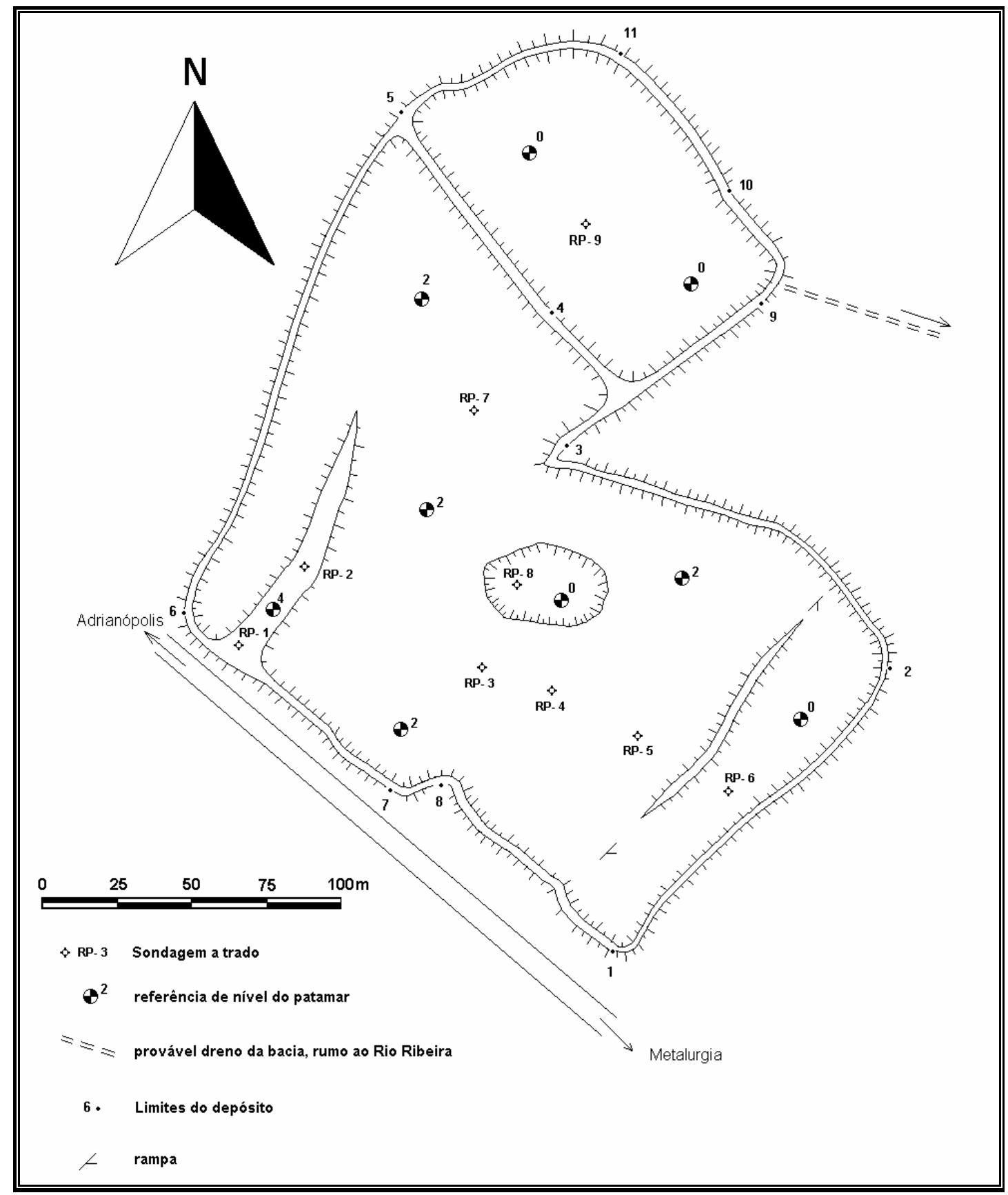

Figura 8 - Planta esquemática do depósito de rejeitos do concentrado da Plumbum Extraído de FRANCHI (2004)

Esta pilha é formada por três patamares distintos gerados pela disposição da polpa, denominados de patamares 0, 2 e 4, com distâncias de aproximadamente $2 \mathrm{~m}$ entre eles. Como o objetivo principal desta pesquisa não era a caracterização detalhada de toda a pilha de rejeito da Plumbum e sim apenas obter dados representativos da área para comparar com os materiais encontrados nos sedimentos, optou-se por analisar apenas as amostras referentes ao patamar $2 \mathrm{~m}$, pois representam $60 \%$ do total da área pesquisada. 
Estas amostras seguiram o mesmo procedimento de pré-tratamento adotado para os rejeitos da Mina do Rocha. As alíquotas resultantes do pré-tratamento foram utilizadas nas seguintes caracterizações analíticas: granulométrica, mineralógica, química e em microscopia eletrônica de varredura.

\section{Caracterização das Amostras}

1. Análise Granulométrica

Para determinação granulométrica destes rejeitos empregou-se método do densímetro de Boyoucos. Neste procedimento são utilizadas 50 gramas de amostra, sendo que a dispersão da argila é realizada em solução de hidróxido de sódio (1N) e agitação mecânica. A separação das frações argila e silte ocorrem por cilindro de sedimentação, onde a concentração da argila é medida pelo densímetro.

A fração maior que $0,062 \mathrm{~mm}$ foi analisada por peneiramento a úmido, método baseado nas normas ABNT. Ambas análises foram realizadas no Laboratório de Física dos Solos do Centro de Energia Nuclear na Agricultura (CENA), Campus Piracicaba da USP.

2. Análise Mineralógica

Estas análises tiveram por objetivo identificar os minerais presentes nos rejeitos da Plumbum a partir do método da difratometria de raios X. Para tal determinação, as amostras foram moídas em panela de ágata (pó de 200 mesh) e posteriormente foram prensadas em lâmina de vidro. As lâminas foram analisadas em Difratômetro Siemens/Bruker D5000 com radiação Cuk $(\alpha)$ e com tensão de $40 \mathrm{KW}$ e $40 \mu \mathrm{A}$, no Laboratório de Difração de Raios X do IGc da USP. Os difratogramas foram obtidos com $2 \theta$ variando de 3 a $65^{\circ}$ e com contagem de 1 segundo por passo de 0,05 grau/2 $\theta$.

\section{Análises Químicas}

Este procedimento foi similar ao adotado para os rejeitos do concentrado da Mina do Rocha, que consistiu na detecção de elementos maiores, menores e traços por Fluorescência de Raios X no LCT da POLI - USP.

4. Análises em Microscópio Eletrônico de Varredura

Para investigação dos metais pesados nos rejeitos e análise da morfologia dos grãos, foi aplicada técnica de microscopia eletrônica de varredura, anteriormente citada e explicada para os rejeitos do concentrado da Mina do Rocha.

\subsection{Resíduos da Metalurgia}

Os resíduos da metalurgia foram produzidos pela empresa Plumbum durante o processo de fundição do minério, e aproximadamente por 40 anos foram lançados nas 
águas do Rio Ribeira de Iguape. Na década de 90 estas escórias foram depositadas, na forma de pilha, diretamente sobre o solo da antiga empresa Plumbum, permanecendo até os dias atuais.

Nos trabalhos de campo realizados em fevereiro de 2002, detectou-se imensa pilha de escória com volume aproximado de $200.000 \mathrm{~m}^{3}$ (FRANCHI, 2004). Esta pilha situa-se nas proximidades da área onde foi encontrado depósito de rejeitos do concentrado da Plumbum.

Estas escórias consistem de material de coloração preta, magnético, coesão e umidade baixas, e granulometria predominantemente na fração areia (Figura 9). Este material foi amostrado em uma malha irregular de $50 \mathrm{em} 50 \mathrm{~m}$ (percorrendo toda a pilha) com pá e foram armazenados em sacos de polietileno, recebendo a sigla $\mathrm{E}$ (I até $\mathrm{VI})$.

O pré-tratamento destas amostras consistiu em secagem (temperatura ambiente), por aproximadamente 1 semana e quarteamento (em pilhas alongadas) para fornecimento de alíquotas necessárias às diversas caracterizações e análises laboratoriais.

Os resultados obtidos para as escórias, também foram tratados estatisticamente pelo CEA do IME da USP e foram comparados com as normas técnicas ABNT (1987a, b e c); para resíduos sólidos (NBR 10.005) como indicativo de uma potencial contaminação.

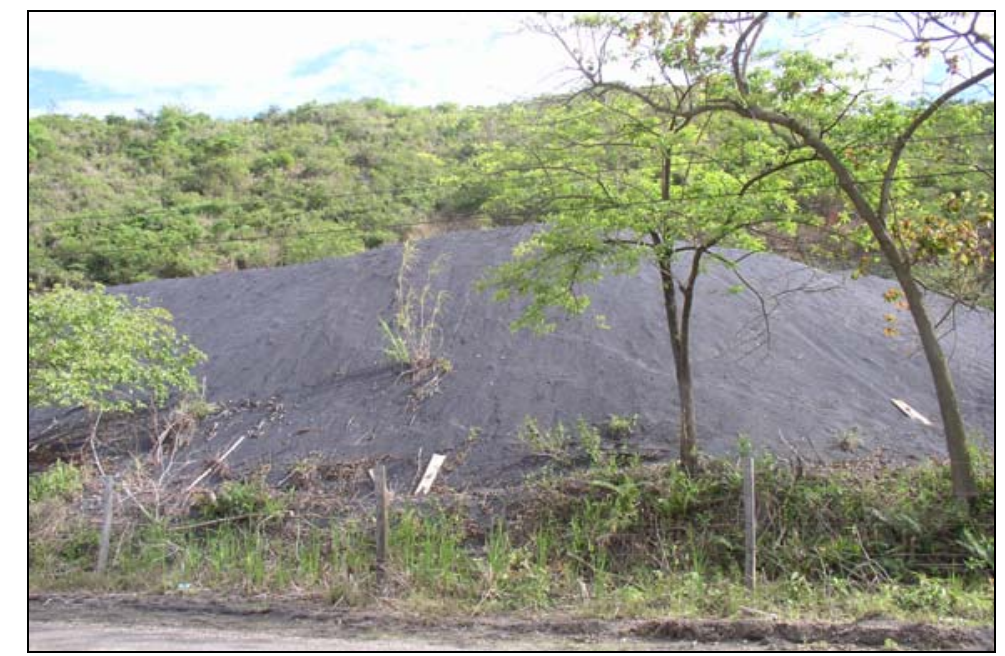

Figura 9 - Pilha de escória depositada na área da mina de Panelas pela empresa Plumbum

\section{Caracterização das Amostras}

1. Densidade

Para a determinação da densidade real da escória utilizou-se picnômetro, enquanto que a densidade relativa foi determinada pelo método da proveta, sendo realizadas no Laboratório de Química do IGc da USP. 


\section{Análise Granulométrica}

A granulometria da escória foi obtida por peneiramento a seco no Laboratório de Sedimentologia do IGc da USP, uma vez que este material não apresentava frações mais finas (como argila e silte).

\section{Análise Mineralógica}

Tiveram por objetivo identificar os minerais presentes nas escórias a partir do método da difratometria de raios $X$. A escória apresentou elevado grau de interferência, o que prejudicou muito tal análise.

As análises químicas e em MEV seguiram os mesmos procedimentos adotados para as análises de rejeito do concentrado e foram realizadas nos mesmos laboratórios com os mesmos equipamentos.

\subsection{SEDIMENTOS}

Em função do lançamento dos resíduos de mineração e metalurgia nas águas do Rio Ribeira de Iguape, por um longo período, tornou-se necessário um levantamento detalhado dos efeitos causados por estes materiais nesta bacia hidrográfica. Os sedimentos representam importante parâmetro na análise da dinâmica e distribuição dos metais pesados, uma vez que os elementos transportados pela coluna d'água estão associados a este tipo de material.

Para caracterizar o efeito destes resíduos no Rio Ribeira de Iguape, optou-se pelo estudo de quatro diferentes tipos de sedimentos: a) em bancos de areia, b) ativos de corrente, c) em suspensão e d) estuarinos.

Os dados obtidos para os diferentes tipos de sedimentos foram tratados estatisticamente no CEA do IME da USP. Como indicativo da possível contaminação destes materiais foi empregado valor de referência para sedimentos, elaborado pelo Canadian Council of Ministers of the Environment (CCME, 1999), os quais são divididos em duas categorias de classificação: TEL ("Threshold Effect Level") e PEL ("Probable Effect Level"). O parâmetro TEL consiste em uma concentração abaixo da qual não são esperados efeitos adversos sobre organismos aquáticos. PEL representa uma concentração acima da qual são esperados efeitos adversos severos sobre os organismos aquáticos. Neste estudo, os resultados obtidos foram comparados com valores de background regionais delimitados pela Coordenadoria de Proteção dos Recursos Naturais - CPRN (1978). 


\subsubsection{Sedimentos em bancos de areia}

Os sedimentos depositados em bancos de areia, também conhecidos na literatura como "overbank", representam em parte, os depósitos mais antigos da sedimentação fluvial, e desta forma podem conter dados históricos da deposição dos resíduos lançados no Rio Ribeira de Iguape.

Esses sedimentos foram amostrados em dois segmentos do Rio Ribeira de Iguape (Iporanga-Eldorado e Eldorado-Sete Barras) e na confluência do Rio Ribeira com o Rio Juquiá. Esta amostragem ocorreu durante a estação climática seca, nos anos de 2003 até 2005.

Estes segmentos foram escolhidos em decorrência da facilidade no acesso e também, por se tratar de uma região com menor gradiente hidráulico o que possibilita a deposição de materiais proveniente do Alto e Médio curso do Rio Ribeira. As amostras coletadas na junção do Rio Ribeira com o Rio Juquiá representam o branco analítico, caracterizando a deposição de sedimentos provindos do Rio Juquiá, o qual não recebeu material proveniente da atividade mineral do Alto Vale do Ribeira.

A localização dos pontos de amostragem, bem como as diferenças granulométricas e deposicionais podem ser observadas nas figuras 10 e 11. 


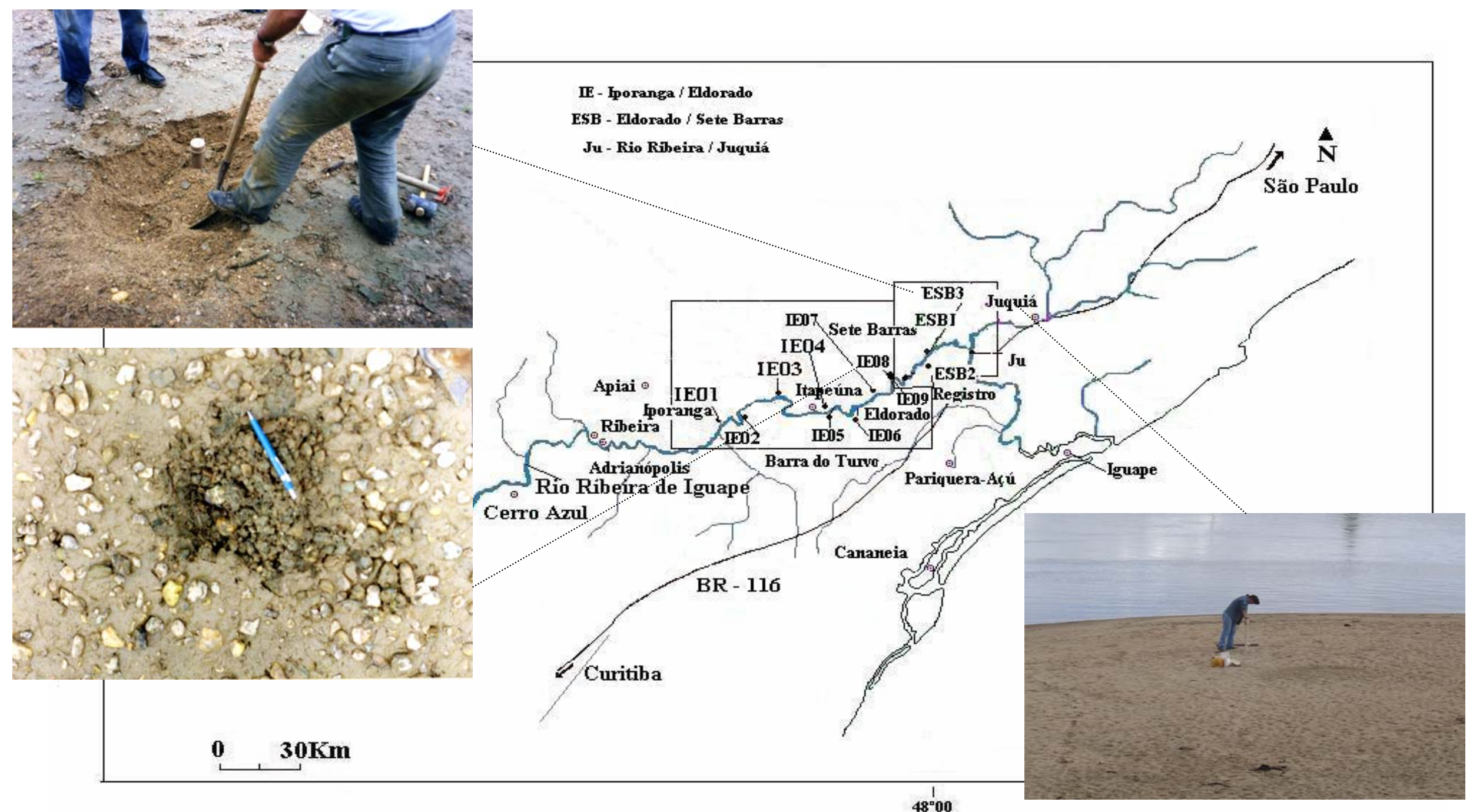

Figura 10 - Mapa de localização dos pontos de amostragem, com detalhes das variações granulométricas dos sedimentos depositados em bancos de areia. 


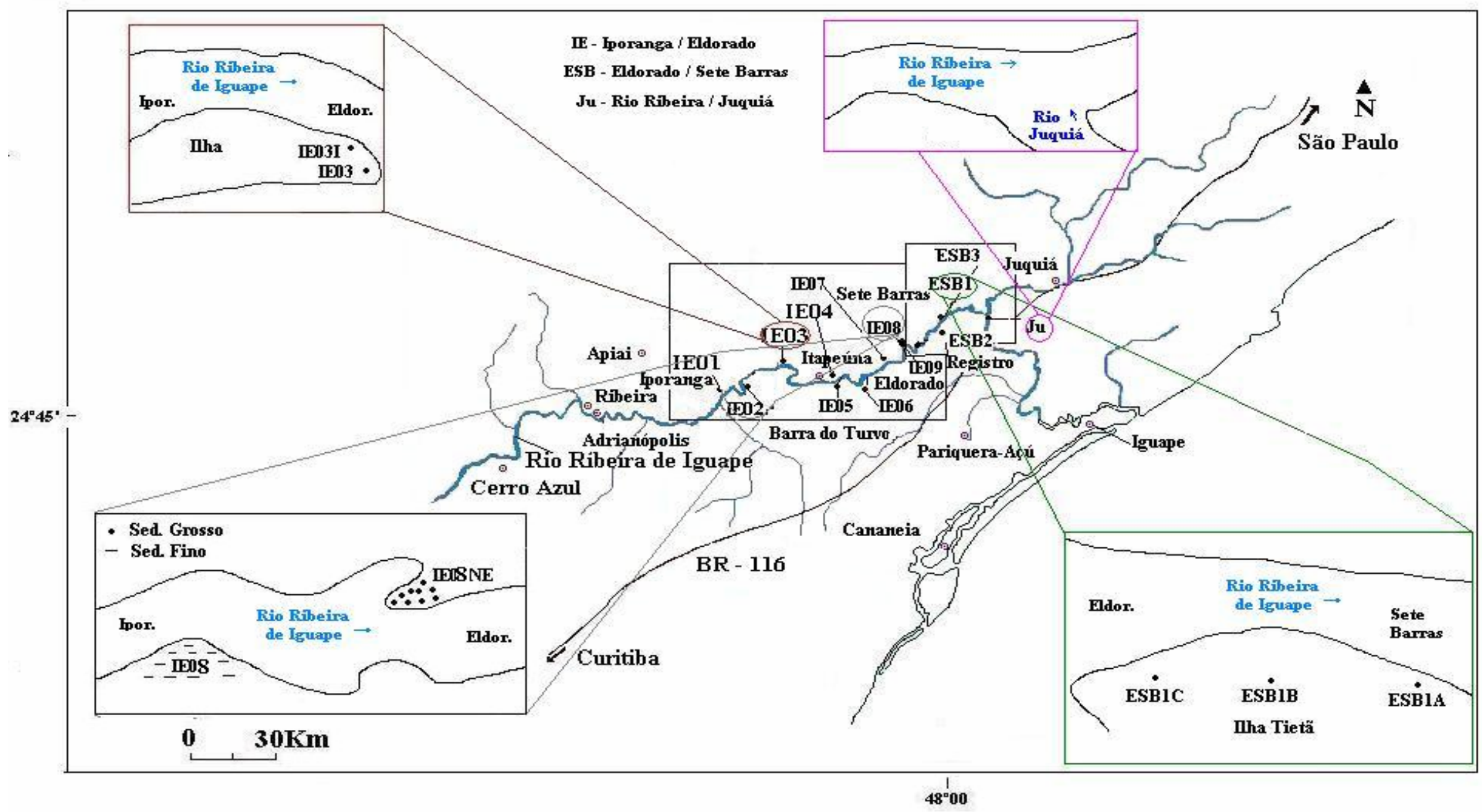

Figura 11 - Mapa de localização dos pontos de amostragem dos sedimentos em bancos de areia, com detalhes de alguns pontos de coleta que apresentaram particularidades na área deposicional. 
Nestes bancos de areia a coleta foi realizada com tubo de PVC de aproximadamente 1,0 m de comprimento, tampa de PVC e marreta de borracha (Figura 12), conforme já empregado em Guimarães (2001). O perfil gerado em cada ponto de amostragem foi subamostrado no campo em topo, meio e base.

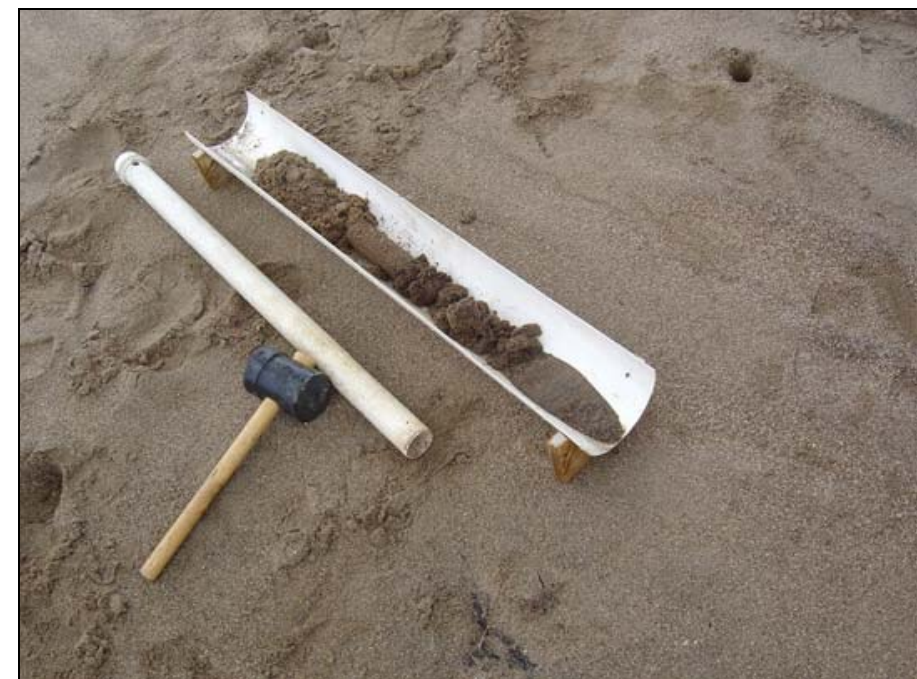

Figura 12 - Materiais empregados na coleta do perfil de sedimento depositado em banco de areia

Estes sedimentos foram acondicionados em sacos plásticos de polietileno e foram identificados como: IE (Iporanga-Eldorado), ESB (Eldorado-Sete Barras) e JU (Juquiá), recebendo também as siglas $T, M$ e $B$ (quando subdivididas em topo, meio e base, respectivamente).

Todas as amostras de sedimento foram submetidas à secagem a $40^{\circ} \mathrm{C}$ até peso constante, homogeneização e quarteamento, mesma metodologia aplicada para as amostras de resíduos.

\section{Caracterização das Amostras}

1. Análise Granulométrica

Para determinação granulométrica dos sedimentos empregou-se método do densímetro de Boyoucos e peneiramento a úmido (fração maior que 0,062 mm), mesma metodologia adotada para as amostras de rejeito da Plumbum.

\section{Determinação do Conteúdo de Matéria Orgânica}

A dosagem do conteúdo de matéria orgânica foi realizada no Laboratório de Sedimentologia do IGc da USP, a partir do ataque do sedimento seco, aproximadamente $5 \mathrm{~g}$ de amostra, por água oxigenada "Peróxido de Hidrogênio" (a 100 volumes e 30\%) a quente (chapa com temperatura de 40 a $50^{\circ} \mathrm{C}$ ). 


\section{Análises Químicas}

Para análise química dos sedimentos, separou-se por peneiramento a fração menor que 2,00 mm. Esta fração foi moída em panela de ágata (granulometria na faixa de 325 mesh) e o pó resultante foi prensado em pastilha. As pastilhas foram analisadas em espectrômetro de fluorescência raios $X$.

4. Análises em Microscópio Eletrônico de Varredura

Os sedimentos foram preparados em "stubs", recobertos com carbono e analisados em microscópio eletrônico de varredura no Laboratório de Microscopia Eletrônica do IGc USP.

\subsubsection{Sedimentos ativos de corrente}

Para verificar o que está sendo transportado atualmente pelo rio por arrasto, foram amostrados sedimentos ativos de corrente em três localidades: Iporanga, Eldorado e Sete Barras (Figura 13).

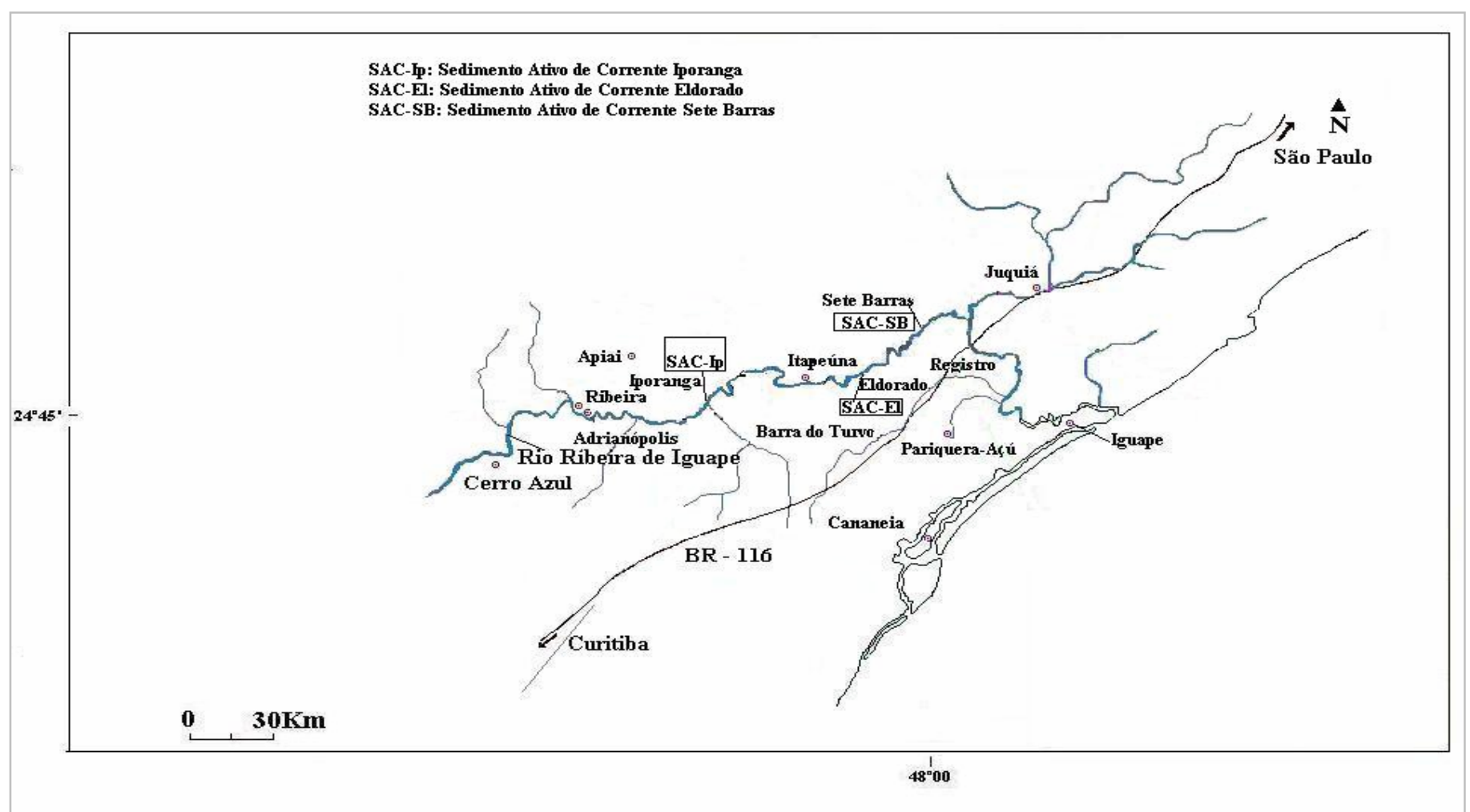

Figura 13 - Mapa de localização dos pontos de coleta dos sedimentos ativos de corrente

A amostragem deste material foi realizada em 2005 na estação seca, na porção mais rasa do rio. A coleta foi realizada com espátula de plástico e as amostras foram acondicionadas em sacos plásticos de polietileno fechados a vácuo. Os sedimentos foram 
congelados até o momento da análise e receberam a sigla SAC juntamente com a inicial do ponto de coleta. Antes de serem analisadas elas foram submetidas à homogeneização, quarteamento e secagem a $40^{\circ} \mathrm{C}$.

\section{Caracterização das Amostras}

1. Análise Química

As amostras foram peneiradas sendo que a fração menor que 2,00 $\mathrm{mm}$ foi moída em panela de ágata. Foram realizados dois tipos distintos de análise: a) Análise dos teores totais e b) Análise dos teores extraídos. Ambas análises foram executadas em Espectrômetro de Emissão Ótica com fonte de plasma ICP/OES modelo OPTIMA 3000DV (Perkin Elmer) no Laboratório de Química Analítica do CENA "Henrique Bergamin Filho" Campus Piracicaba - USP.

\section{A) Análise dos teores totais}

O preparo da amostra consistiu em: 0,5000 g (de acordo com a precisão da balança) de sedimento (60 mesh) pesado em balança e colocado em bombas de teflon. Foi adicionado $5 \mathrm{~mL}$ de água régia e $1 \mathrm{~mL}$ de ácido fluorídrico, as bombas foram fechadas e colocadas em blocos digestores com controle de temperatura (Tecnal), a temperatura foi sendo elevada gradualmente até $200^{\circ} \mathrm{C}$, ficando no aquecimento por $5 \mathrm{~h}$. Depois de frias as bombas foram abertas e adicionou-se $1 \mathrm{~mL}$ de ácido percloríco, aumentando-se a temperatura até $210^{\circ} \mathrm{C}$, até atingir quase a secura para evaporação do HF. O volume foi completado para $10 \mathrm{~mL}$ com HCl $1 \mathrm{~mol} / \mathrm{L}$

\section{B) Análise dos teores extraídos}

Para analisar os teores extraídos, preparou-se $1 \mathrm{~g}$ do pó de sedimento com $5 \mathrm{~mL}$ de água régia. Este material foi aquecido até $160^{\circ} \mathrm{C}$ por 4 horas e o volume foi completado com água destilada até atingir $10 \mathrm{~mL}$.

\subsubsection{Sedimentos em suspensão}

Os sedimentos em suspensão são formados predominantemente por minerais de argila; óxidos e hidróxidos de ferro e manganês; carbonatos e substâncias orgânicas (ácidos humicos), além de materiais biológicos (algas, bactérias e plânctons) e antropogênicos (BaHEMA-MANJARREZ, 2002). Estes sedimentos apresentam capacidade de carrear os metais pesados entre a fase dissolvida e particulada através de processos de adsorção e co-precipitação, sendo assim considerados importantes no transporte de metais pesados em ambientes aquáticos. 
Desta forma, para verificar se está ocorrendo remobilização e transporte por suspensão dos metais pesados depositados nos sedimentos de fundo e em bancos de areia do Rio Ribeira de Iguape, bem como, detectar a atual contribuição das chuvas na lixiviação e entrada dos resíduos depositados em pilhas nas proximidades das drenagens deste rio, foram coletadas amostras de sedimentos em suspensão durante o período climático seco, nos anos de 2003 e 2004.

Estes sedimentos foram coletados em tanques de decantação em 4 unidades de extração de areia localizadas, respectivamente em: Eldorado, Sete Barras, Registro e Iguape (Figura 14).

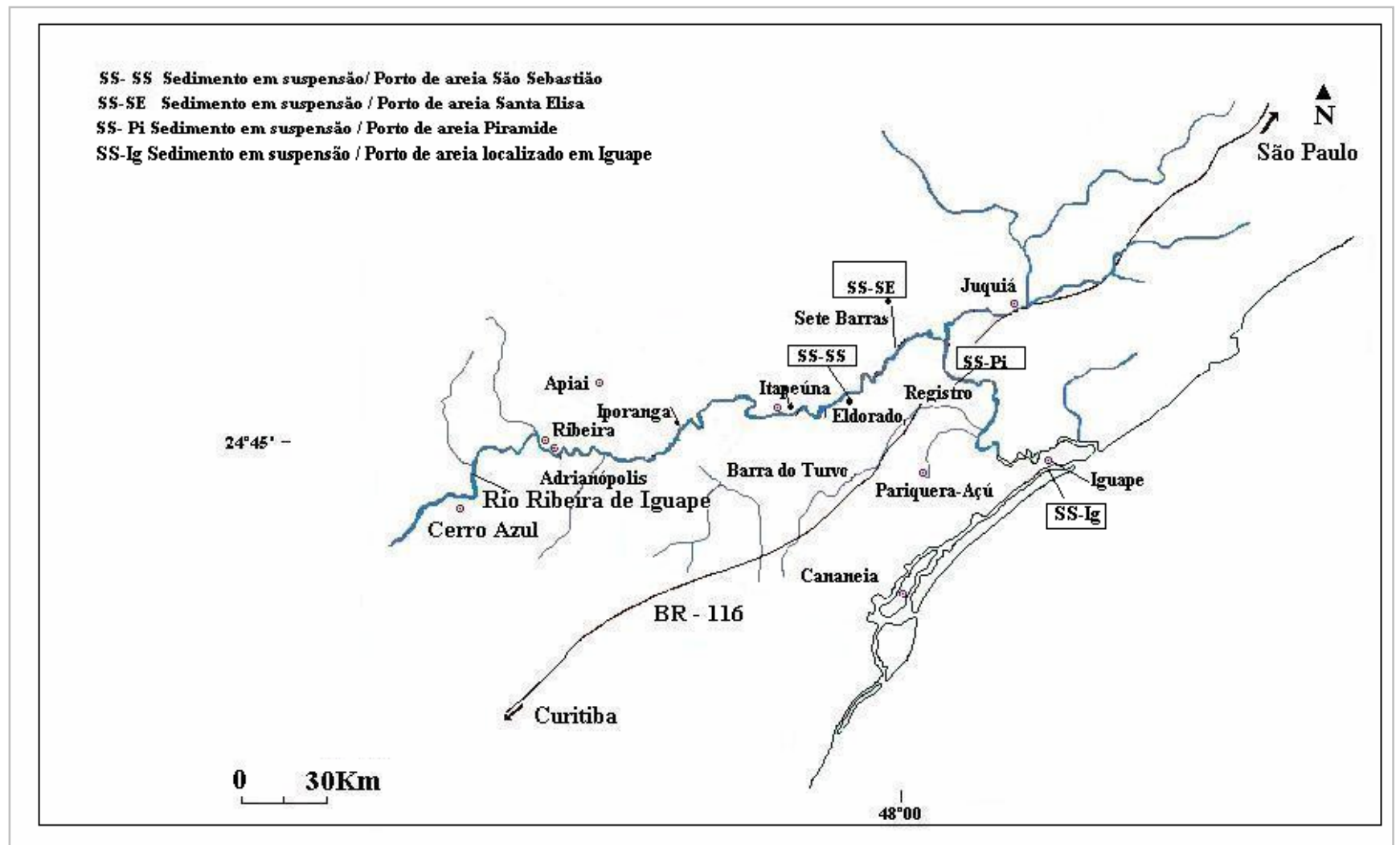

Figura 14 - Mapa de localização dos sedimentos em suspensão

A coleta deste material foi realizada a partir do emprego de espátula e sacos de polietileno fechados a vácuo, sendo que estes permaneceram congelados até serem analisados. (Figura 15). Estas amostras receberam a sigla do porto de areia onde foram coletadas, ficando representadas da seguinte forma: SS-SS amostras de sedimento em suspensão coletadas no porto de areia São Sebastião em Eldorado; SS-SE amostras de sedimento em suspensão coletadas no porto de areia Santa Elisa em Sete Barras; SS-Pi amostras de sedimento em suspensão coletadas no porto de areia Pirâmide em Registro e 
SS-Ig amostras de sedimento em suspensão coletadas no porto de areia localizado em Iguape.

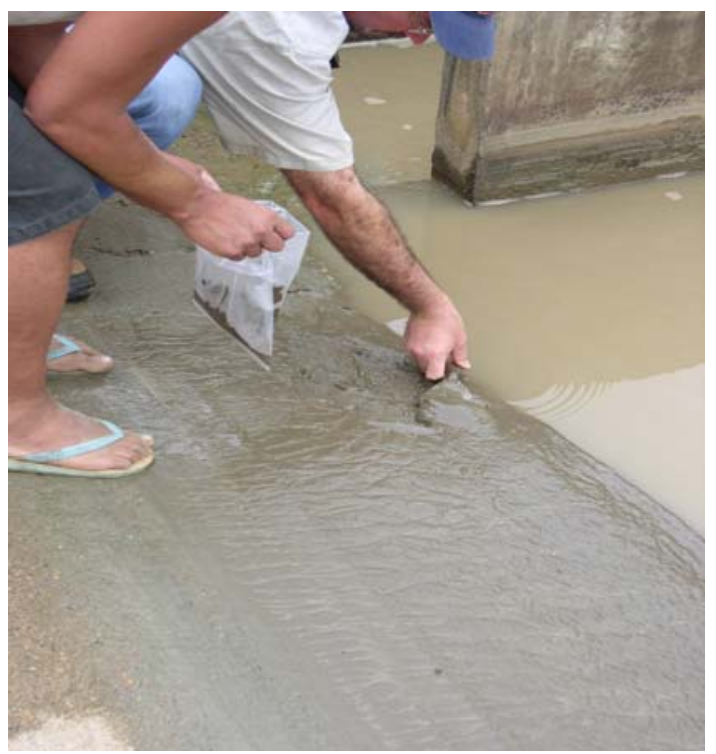

Figura 15 - Coleta do sedimento em suspensão em tanque de decantação

No campo foram determinados os parâmetros físico-químicos, $\mathrm{pH}$ e Eh, destes sedimentos com emprego de pHmetro portátil DIGIMED.

Em laboratório estes sedimentos foram submetidos à secagem, homogeneização e quarteamento, obedecendo aos mesmos procedimentos aplicados nos outros tipos de sedimentos e nos resíduos, aqui já abordados.

Nestes sedimentos foi identificada a presença de minerais magnéticos, utilizando-se para tanto um imã. Esta porção magnética foi separada e analisada química e microscopicamente, com o intuito de detectar a escória que foi lançada no rio.

\section{Caracterização das Amostras}

\section{A) Sedimentos em Suspensão}

As análises granulométricas, conteúdo de matéria orgânica, análises químicas e em MEV, obedeceram aos meus procedimentos e foram executadas nos mesmos laboratórios que foram descritos para os sedimentos em bancos de areia.

\section{B) Parte Magnética do Sedimentos em Suspensão}

\section{Análises Químicas}

A parte magnética do sedimento foi separada com imã e foi prensado em pastilha. As pastilhas foram analisadas em espectrômetro de fluorescência raios $X$, no mesmo laboratório e com a mesma técnica já descrita. 
2. Análises em Microscópio Eletrônico de Varredura

A parte magnética foi preparada em "stub" e foi analisada pela mesma técnica que foi empregada para os sedimentos e resíduos.

\subsubsection{Sedimentos estuarinos}

Este tipo de sedimento representa a contribuição da sedimentação do Rio Ribeira de Iguape no complexo estuarino lagunar Iguape-Cananeia. Em trabalhos anteriores (TESLLER, et al. 1998; TESLLER, 2001) foram detectados nestes sedimentos teores elevados de metais pesados oriundos das atividades de mineração realizadas no Alto Vale do Ribeira. O sedimento estuarino foi amostrado em uma das pontas da ilha do Caranguejo (nas proximidades de Iguape, início do Mar Pequeno), como observado na figura abaixo. 


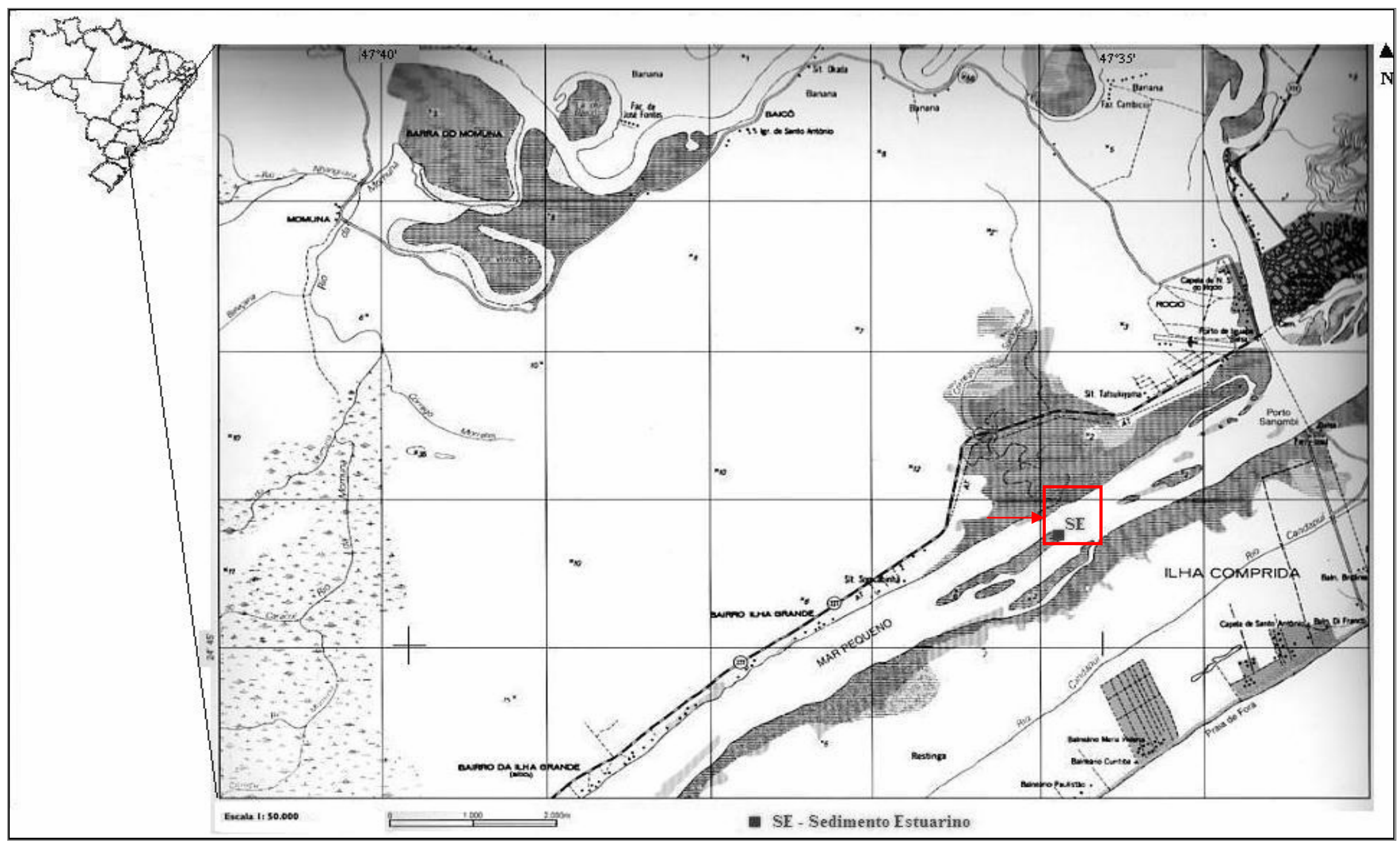

Figura 16 - Localização do ponto de coleta do sedimento estuarino 
Nesta amostragem empregou-se tubo de PVC de aproximadamente 1,0 $\mathrm{m}$ de comprimento, tampa de PVC e marreta de borracha. O perfil gerado foi sub-amostrado de 20 em $20 \mathrm{~cm}$ e foram denominados de SE juntamente com a profundidade amostrada (Figura 17).

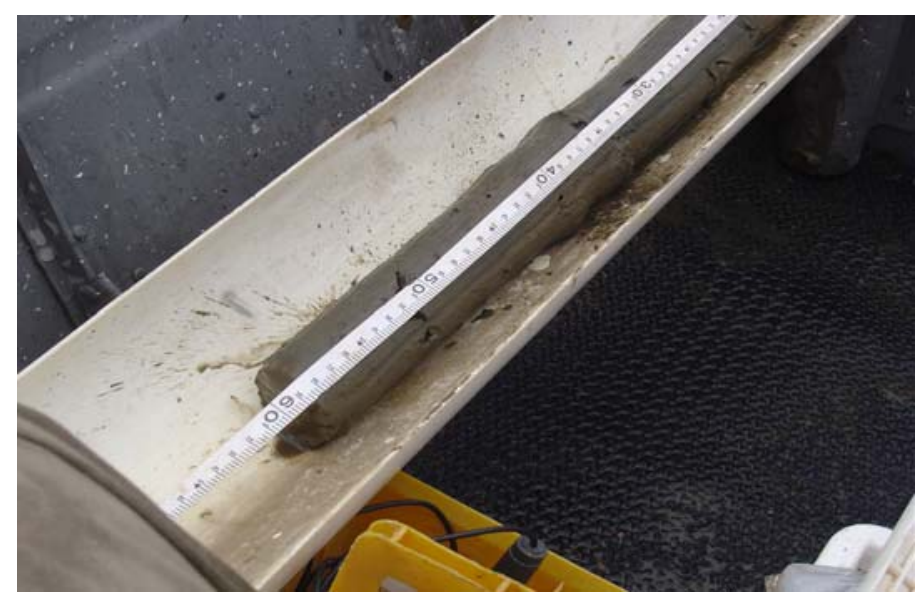

Figura 17 - Amostragem do perfil de sedimento estuarino

$\mathrm{Na}$ porção de topo e base deste perfil foram obtidos parâmetros físico-químicos (pH e Eh) com pHmetro portátil DIGIMED.

O armazenamento, secagem, homogeneização e quarteamento destes materiais, obedeceram aos mesmos procedimentos aplicados nos outros tipos de sedimentos, já abordados.

\section{Caracterização das Amostras}

As análises granulométricas, conteúdo de matéria orgânica, análises químicas e em MEV, obedeceram aos meus procedimentos e foram executadas nos mesmos laboratórios que foram descritos para os sedimentos em bancos de areia.

\subsection{BIOMONITORES}

A mobilidade dos metais pesados nos sedimentos e sua biodisponibilidade para organismos vivos dependem dentre outros diversos aspectos, de sua forma química, de sua ligação com as partículas de sedimento e das condições físico químicas do meio (pH e Eh). Em diversos ambientes atualmente, uma avaliação completa de toxicidade pode ser realizada com o estudo de espécie biomonitora, uma vez que a biodisponibilidade é medida diretamente no ambiente de existência destes organismos.

$\mathrm{Na}$ Bacia do Rio Ribeira de Iguape durante as missões de campo para coleta de sedimentos foi encontrada espécie considerada na literatura como biomonitor, bivalve da família Corbiculidae, classificada como Corbicula fluminea (Figura 18). 
Este bivalve foi coletado manualmente através do exame tátil do sedimento de fundo, do município de Iporanga até Iguape, nos anos de 2004 e 2005 durante período climático de baixa pluviosidade. Os exemplares coletados foram acondicionados em sacos plásticos fechados a vácuo, denominado de CF juntamente com a sigla de sua localidade (Ip, El, SB e PA) e foram congelados até o momento da análise.

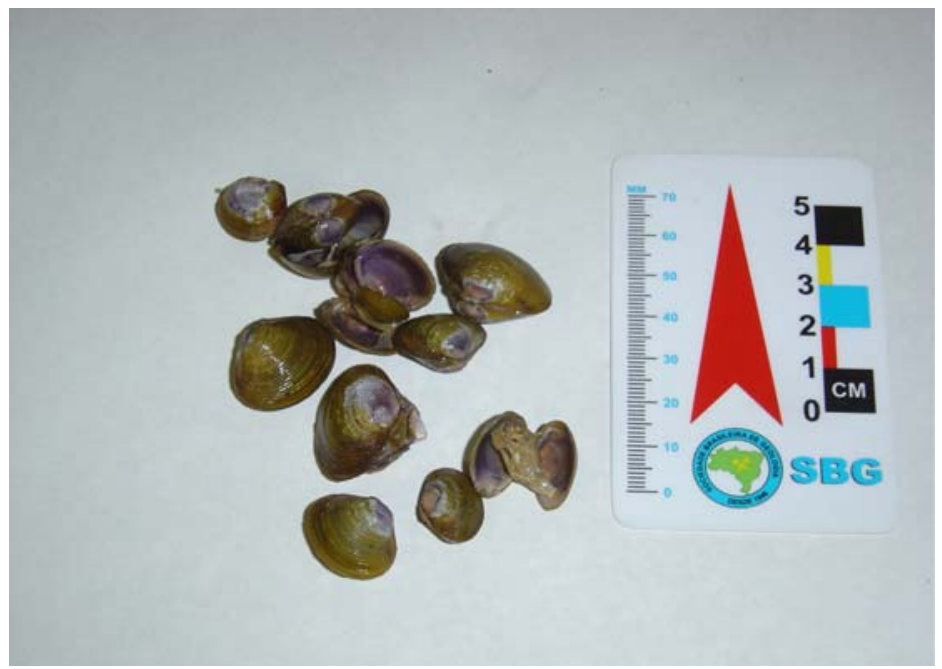

Figura 18 - Espécie de biomonitor - Corbicula fluminea

A Corbicula fluminea foi inicialmente descongelada à temperatura ambiente e pesadas. A parte mole (tecido) foi retirada com auxílio de uma espátula de teflon, lavada com água bi-destilada, seca parcialmente em papel de filtro e congelada até a data da análise, conforme metodologia empregada em TOMAZELLI (2003). Além destes procedimentos estas mesmas amostras foram todas liofilizadas (Figura 19) e pesadas, sendo a seguir moídas em moinho criogênico para obtenção de amostras homogêneas para posterior determinação dos metais pesados.

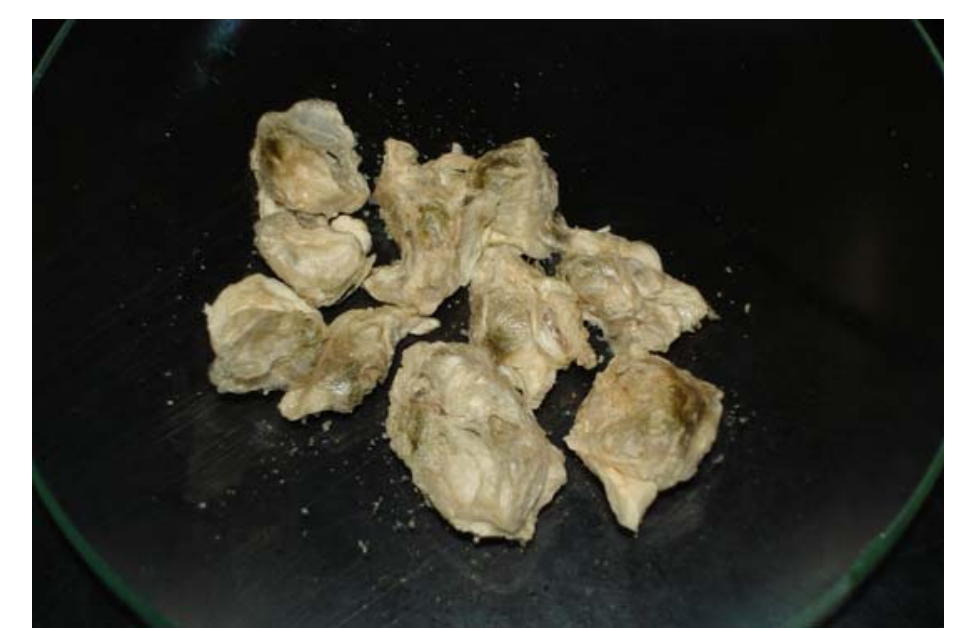

Figura 19 - Tecidos liofilizados dos bivalves (Corbiculas flunineas) 
Além da análise dos tecidos, também foram realizados estudos nas carapaças destes bivalves. Para esta análise, as carapaças foram moídas em moinho de ágata, homogeneizadas, acondicionadas em sacos plásticos fechados a vácuo e denominadas de CB.

\section{Caracterização das Amostras}

1. Análise Química dos Tecidos

Para determinação dos metais pesados nos tecidos dos bivalves, foi executado o seguinte procedimento: as amostras liofilizadas e moídas foram digeridas em frascos de teflon pressurizados em forno de microondas (Millestone). A seguir, $100 \mathrm{~g}$ do tecido recebeu $6 \mathrm{~mL}$ de ácido nítrico $20 \%$ e $2 \mathrm{~mL}$ de peróxido de hidrogênio, o resíduo foi dissolvido em ácido nítrico 0,1 mol/L e completado até $10 \mathrm{~mL}$. Posteriormente, foi analisado em Espectrômetro de Emissão Ótica com fonte de plasma modelo OPTIMA 3000DV (Perkin Elmer). Nesta análise foi utilizado material de referência certificado pelo NIST SRM1566a (OYSTER TISSUE), sendo que os resultados apresentaram concordância ao nível de 95\%. Estes procedimentos foram executados no Laboratório de Química Analítica do CENA "Henrique Bergamin Filho" Campus Piracicaba - USP.

\section{Análise Química das Carapaças}

Para verificação dos teores de metais pesados nas carapaças dos bivalves utilizouse 5 gramas de amostras moídas na fração 200 mesh. Estas amostras foram analisadas em um equipamento de Espectrometria de Emissão Atômica com plasma induzido (ICP-AES), Spectro Ciros CCD, no laboratório de Química da Central Analítica do Instituto de Química da USP. 


\section{RESUlTADOS}

\subsection{RESÍduOS DA MINERAÇÃo}

\subsubsection{Rejeitos do concentrado da Mina do Rocha}

As amostras de rejeito do concentrado coletadas em sondagem de $3,40 \mathrm{~m}$ de profundidade são constituídas basicamente pela fração silte (média de 69,22\% $\pm 6,85$ ), sendo as frações areia e argila aproximadamente iguais (média da fração areia de 15,06\% \pm $3,90$ e média da fração argila de $15,72 \% \pm 5,20)$, como pode ser observado na tabela abaixo.

Tabela 1 - Distribuição granulométrica das amostras de rejeito do concentrado da Mina do Rocha (\%)

\begin{tabular}{lcccr} 
Amostra/Profundidade & $\begin{array}{c}\text { Areia } \\
\text { \% }\end{array}$ & $\begin{array}{c}\text { Silte } \\
\text { \% }\end{array}$ & $\begin{array}{c}\text { Argila } \\
\text { \% }\end{array}$ & $\begin{array}{c}\text { Fechamento } \\
\text { \% }\end{array}$ \\
& & & & $\mathbf{1 0 0 , 0 0}$ \\
\hline \hline MR01 (0,0-0,60m) & 22,56 & 61,22 & 16,22 & $\mathbf{1 0 0 , 0 0}$ \\
MR02 (0,60-0,90m) & 16,53 & 68,94 & 14,53 & $\mathbf{1 0 0 , 0 0}$ \\
MR03 (0,90-1,20m) & 12,15 & 84,59 & 3,26 & $\mathbf{1 0 0 , 0 1}$ \\
MR04 (1,20-1,50m) & 8,61 & 78,92 & 12,48 & $\mathbf{1 0 0 , 0 1}$ \\
MR05 (1,50-1,80m) & 19,75 & 68,82 & 11,44 & $\mathbf{1 0 0 , 0 0}$ \\
MR06 (1,80-2,10m) & 11,64 & 68,55 & 19,81 & $\mathbf{1 0 0 , 0 0}$ \\
MR07 (2,10-2,40m) & 14,75 & 66,11 & 19,14 & $\mathbf{9 9 , 9 9}$ \\
MR08 (2,40-2,60m) & 12,74 & 69,56 & 17,69 & $\mathbf{9 9 , 9 9}$ \\
MR09 (2,60-2,90m) & 14,10 & 65,65 & 20,25 & $\mathbf{9 9 , 9 9}$ \\
MR10 (2,90-3,10m) & 16,17 & 62,57 & 21,25 & \\
MR11 (3,10-3,40m) & 16,66 & 66,48 & 16,85 & \\
\hline \hline Média & $\mathbf{1 5 , 0 6}$ & $\mathbf{6 9 , 2 2}$ & $\mathbf{1 5 , 7 2}$ & \\
\hline \hline Erro & $\mathbf{1 , 1 8}$ & $\mathbf{2 , 0 7}$ & $\mathbf{1 , 5 7}$ & \\
\hline \hline Desvio Padrão & $\mathbf{3 , 9 0}$ & $\mathbf{6 , 8 5}$ & $\mathbf{5 , 2 0}$ & \\
\hline \hline
\end{tabular}

Ao longo desta sondagem, notou-se que as amostras apresentaram pequena variação granulométrica dentro da fração silte. A porção superficial desta sondagem (de 0 até $1,8 \mathrm{~m}$ ) é composta pelas frações silte-arenosa e silte, enquanto que abaixo de 1,8 $\mathrm{m}$ a fração predominante é silte argilosa, de acordo com o diagrama triangular abaixo. Desta forma, entende-se que com o aumento da profundidade, a partir de 1,80 m, as amostras são granulometricamente um pouco mais finas do que as encontradas no topo desta pilha. 


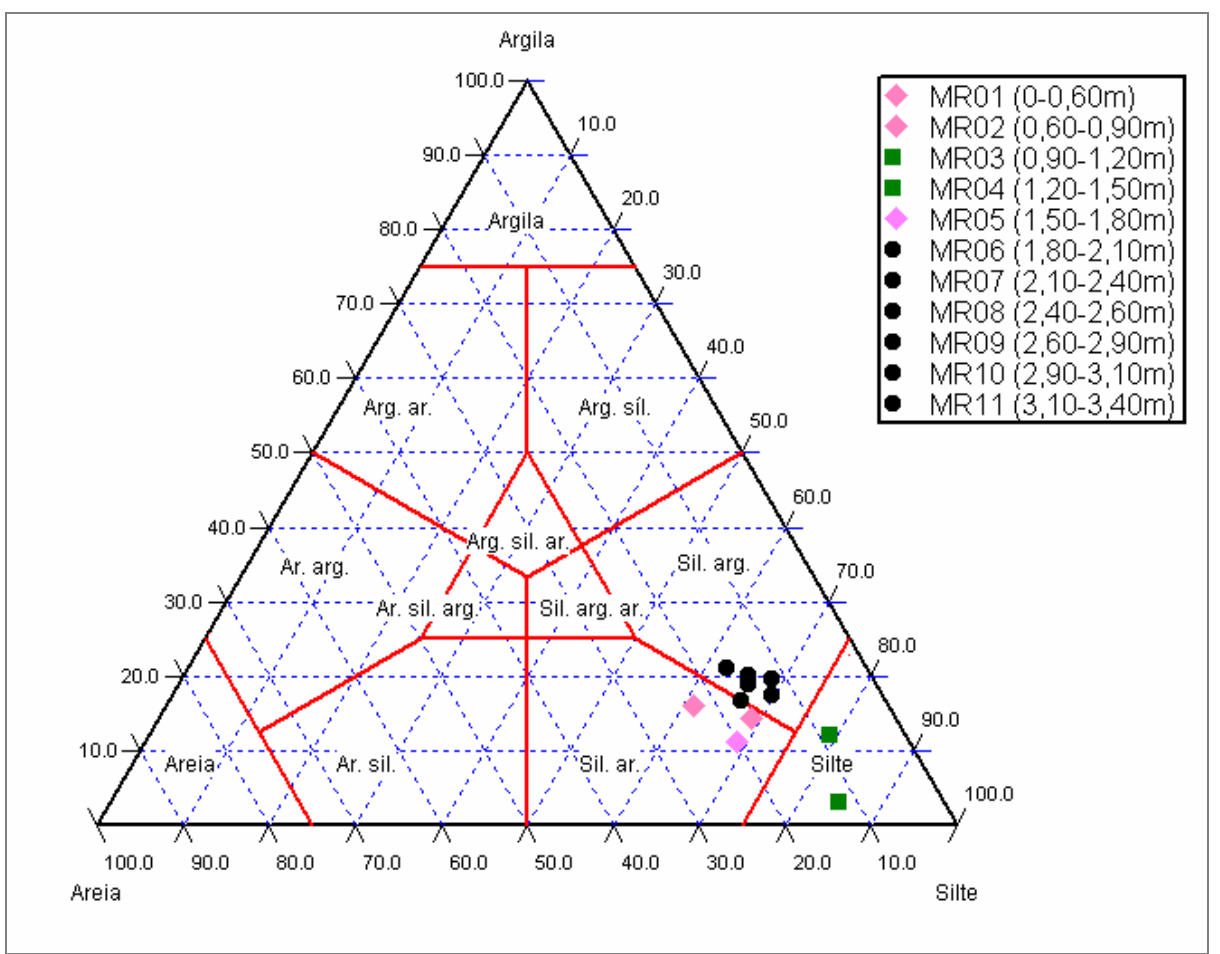

Diagrama Triangular 1 - Variação granulométrica das amostras de rejeito do concentrado da Mina do Rocha, obtidas em sondagem de $3,40 \mathrm{~m}$

Quanto à composição mineral, esta foi considerada separadamente para as frações areia e argila. De modo geral, a fração areia é composta predominante por carbonatos (média de $87,04 \% \pm 7,30$ ) e quartzo (média de $11,87 \% \pm 7,01$ ), perfazendo mais de $98 \%$ da amostra (Tabela 2). Os hidróxidos de ferro, feldspatos, sulfetos e outros minerais são encontrados em pequenas quantidades, geralmente não ultrapassando 1\% em cada uma das amostras (Tabela 2).

Tabela 2 - Mineralogia da fração areia - amostras de rejeito da Mina do Rocha - \%.

\begin{tabular}{|c|c|c|c|c|c|c|c|}
\hline $\begin{array}{c}\text { Amostra } \\
\text { Profundidade }\end{array}$ & $\begin{array}{c}\text { Carbonato } \\
\%\end{array}$ & $\begin{array}{c}\text { Feldspato } \\
\%\end{array}$ & $\begin{array}{c}\text { Hidróxidos de Ferro } \\
\%\end{array}$ & $\begin{array}{c}\text { Quartzo } \\
\%\end{array}$ & $\begin{array}{c}\text { Sulfeto } \\
\%\end{array}$ & $\begin{array}{c}\text { Outros } \\
\%\end{array}$ & $\begin{array}{c}\text { Fechamento } \\
\%\end{array}$ \\
\hline MR01 (0,0-0,60m) & 73,00 & 0,00 & 1,30 & 25,00 & 0,20 & 0,60 & 100,10 \\
\hline MR02 (0,60-0,90m) & 78,80 & 0,00 & 0,90 & 20,00 & 0,10 & 0,20 & 100,00 \\
\hline $\operatorname{MR03}(0,90-1,20 m)$ & 79,00 & 0,20 & 0,30 & 20,00 & 0,20 & 0,20 & 99,90 \\
\hline $\operatorname{MR04}(1,20-1,50 m)$ & 89,30 & 0,00 & 0,00 & 10,10 & 0,80 & 0,00 & 100,20 \\
\hline $\operatorname{MR05}(1,50-1,80 m)$ & 92,00 & 0,20 & 0,30 & 7,50 & 0,00 & 0,00 & 100,00 \\
\hline $\operatorname{MR06}(1,80-2,10 m)$ & 94,50 & 0,00 & 0,40 & 5,00 & 0,10 & 0,00 & 100,00 \\
\hline $\operatorname{MR07}(2,10-2,40 m)$ & 91,20 & 0,10 & 0,50 & 7,50 & 0,30 & 0,50 & 100,10 \\
\hline $\operatorname{MR08}(2,40-2,60 \mathrm{~m})$ & 86,00 & 0,10 & 0,20 & 12,50 & 0,30 & 1,00 & 100,10 \\
\hline $\operatorname{MR09}(2,60-2,90 m)$ & 96,10 & 0,00 & 0,30 & 3,00 & 0,30 & 0,20 & 99,90 \\
\hline $\operatorname{MR10}(2,90-3,10 m)$ & 91,20 & 0,00 & 0,20 & 7,50 & 0,40 & 0,70 & 100,00 \\
\hline $\operatorname{MR11}(3,10-3,40 m)$ & 86,30 & 0,00 & 0,30 & 12,50 & 0,30 & 0,50 & 99,90 \\
\hline $\begin{array}{c}\text { Média } \\
\end{array}$ & 87,04 & 0,05 & 0,43 & 11,87 & (0,27 & 0,35 & \\
\hline Erro & 2,20 & 0,02 & (2,11 & 2,111 & (2,06 & 0,10 & \\
\hline " Desvio Padrão & 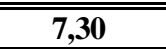 & (20,08 & (0,37 & 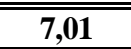 & (0,21 & "0,33 & \\
\hline
\end{tabular}


A fração argila é composta por argilominerais do grupo da esmectita, caulinita e illita, sendo a esmectita o principal mineral participante desta fração (variando entre $70 \%$ a 85\%). O conteúdo de illita nestas amostras ficou entre 5 a 15\%, enquanto que a caolinita ficou entre 10 a 20\%, como exibe a tabela abaixo.

Tabela 3 - Quantificação aproximada dos argilominerais da fração argila - rejeitos da Mina do Rocha (\%)

\begin{tabular}{lccc}
$\begin{array}{c}\text { Amostra } \\
\text { Profundidade }\end{array}$ & $\begin{array}{c}\text { Esmectita } \\
\mathbf{\%}\end{array}$ & $\begin{array}{c}\text { Illita } \\
\mathbf{\%}\end{array}$ & $\begin{array}{c}\text { Caolinita } \\
\mathbf{\%}\end{array}$ \\
\hline \hline MR01 (0,0-0,60m) & & & \\
MR02 (0,60-0,90m) & $75,00-80,00$ & $5,00-10,00$ & $15,00-20,00$ \\
MR03 (0,90-1,20m) & 80,0 & $5,00-10,00$ & 15,0 \\
MR04 (1,20-1,50m) & $80,00-85,00$ & 5,0 & $10,00-15,00$ \\
MR05 (1,50-1,80m) & $70,00-75,00$ & 10,0 & $15,00-20,00$ \\
MR06 (1,80-2,10m) & 75,0 & $5,00-10,00$ & $15,00-20,00$ \\
MR07 (2,10-2,40m) & $80,00-85,00$ & 5,0 & $15,00-20,00$ \\
MR08 (2,40-2,60m) & $75,00-80,00$ & $5,00-10,00$ & 15,0 \\
MR09 (2,60-2,90m) & 80,0 & $5,00-10,00$ & $15,00-20,00$ \\
MR10 (2,90-3,10m) & $75,00-80,00$ & $5,00-10,00$ & 15,0 \\
MR11 (3,10-3,40m) & 70,0 & $10,00-15,00$ & $15,00-20,00$ \\
\hline
\end{tabular}

$\mathrm{Na}$ fração silte, a mais representativa deste rejeito, foi realizada quantificação de dois minerais: dolomita e cerussita. A média de dolomita detectada nesta fração foi de $54,79 \% \pm$ 1,66 , enquanto que a média de cerussita foi da ordem de $1,24 \% \pm 0,57$, conforme tabela 4 . De acordo com Franchi (2004), em vista dos processos de cominuição sofridos na planta de concentração para obtenção do minério abaixo de 100 mesh, pode-se supor que os constituintes da fração silte representam os mesmos da fração imediatamente mais grosseira.

Tabela 4 - Quantificação de dolomita e cerussita na fração silte - rejeitos Mina do Rocha - \%

\begin{tabular}{ccc}
$\begin{array}{c}\text { Amostra } \\
\text { Profundidade }\end{array}$ & $\begin{array}{c}\text { Dolomita } \\
\text { \% }\end{array}$ & $\begin{array}{c}\text { Cerussita } \\
\text { \% }\end{array}$ \\
\hline \hline MR01 (0,0-0,60m) & 53,16 & 1,66 \\
MR02 (0,60-0,90m) & 53,08 & 1,88 \\
MR03 (0,90-1,20m) & 53,14 & 1,59 \\
MR04 (1,20-1,50m) & 53,79 & 1,89 \\
MR05 (1,50-1,80m) & 56,28 & 0,86 \\
MR06 (1,80-2,10m) & 57,28 & 0,66 \\
MR07 (2,10-2,40m) & 54,37 & 1,63 \\
MR08 (2,40-2,60m) & 55,30 & 1,60 \\
MR09 (2,60-2,90m) & 56,34 & 1,01 \\
MR10 (2,90-3,10m) & 53,12 & 0,54 \\
MR11 (3,10-3,40m) & 56,85 & 0,35 \\
\hline Média & 54,79 & 1,24 \\
\hline \hline Erro & 0,5 & 0,17 \\
\hline \hline Desvio Padrão & 1,66 & 0,57 \\
\hline
\end{tabular}


Quanto à composição química deste rejeito, em \% de óxidos, nota-se que há o predomínio de $\mathrm{CaO}$ (média de 25,79\% \pm 1,22), $\mathrm{MgO}$ (média de 16,62\% \pm 0,81) e $\mathrm{SiO}_{2}$ (média de $15,75 \% \pm 2,16$ ), os outros elementos analisados contribuem com percentagens menores que 2\% (Tabela 5). Os teores elevados de $\mathrm{CaO}$ e MgO são reflexos da litologia da rocha encaixante do minério extraído, estes elementos tendem a se concentrar na porção basal do perfil, a partir da profundidade de $1,5 \mathrm{~m}$, exceto para a profundidade de $2,10 \mathrm{~m}$ onde a concentração de $\mathrm{CaO}$ e MgO é menor (Gráfico 6 e Tabela 5). No gráfico 6, nota-se que o Si exibe tendência de concentração química inversa ao dos elementos $\mathrm{Ca}$ e $\mathrm{Mg}$, sendo que o Si concentra-se no topo do perfil e na profundidade de 2,10 m.

Tabela 5 - Análise química total das amostras de rejeito da Mina do Rocha - FRX - \% de óxidos

\begin{tabular}{|c|c|c|c|c|c|c|c|c|c|c|c|c|c|c|c|c|c|c|c|}
\hline $\begin{array}{c}\text { Amostra } \\
\text { Profundidade }\end{array}$ & $\begin{array}{c}\mathrm{SiO}_{2} \\
\%\end{array}$ & $\begin{array}{c}\mathrm{Al}_{2} \mathrm{O}_{3} \\
\%\end{array}$ & $\begin{array}{c}\mathrm{MnO} \\
\%\end{array}$ & $\begin{array}{c}\text { MgO } \\
\%\end{array}$ & $\begin{array}{c}\mathrm{CaO} \\
\%\end{array}$ & $\begin{array}{c}\mathrm{Na}_{2} \mathrm{O} \\
\%\end{array}$ & $\begin{array}{c}\mathrm{K}_{2} \mathrm{O} \\
\%\end{array}$ & $\begin{array}{c}\mathrm{TiO}_{2} \\
\%\end{array}$ & $\begin{array}{c}\mathbf{P}_{2} \mathbf{O}_{5} \\
\%\end{array}$ & $\begin{array}{c}\mathrm{SO}_{3} \\
\%\end{array}$ & $\begin{array}{c}\mathrm{Fe}_{2} \mathbf{O}_{3} \\
\%\end{array}$ & $\begin{array}{c}\mathrm{BaO} \\
\%\end{array}$ & $\begin{array}{c}\mathrm{Cr}_{2} \mathrm{O}_{3} \\
\%\end{array}$ & $\begin{array}{c}\mathrm{CuO} \\
\%\end{array}$ & $\begin{array}{c}\mathrm{ZnO} \\
\%\end{array}$ & $\begin{array}{c}\text { PbO } \\
\%\end{array}$ & $\begin{array}{c}\text { Outros } \\
\%\end{array}$ & $\begin{array}{l}\text { PF } \\
\%\end{array}$ & $\begin{array}{c}\text { Fechamento } \\
\%\end{array}$ \\
\hline MR01 (0,0-0,60m) & 18,60 & 2,02 & 0,14 & 17,00 & 25,20 & 0,01 & 0,77 & 0,09 & 0,07 & 0,28 & 1,92 & 0,05 & 0,03 & 0,06 & 0,06 & 1,19 & 0,12 & 33,70 & 101,31 \\
\hline $\operatorname{MR02}(0,60-0,90 \mathrm{~m})$ & 16,40 & 2,34 & 0,12 & 15,80 & 25,60 & 0,01 & 0,92 & 0,10 & 0,06 & 0,52 & 2,29 & 0,07 & 0,02 & 0,10 & 0,08 & 1,77 & 0,12 & 35,10 & 101,42 \\
\hline $\operatorname{MR03}(0,90-1,20 \mathrm{~m})$ & 17,90 & 2,03 & 0,12 & 15,20 & 23,70 & 0,00 & 0,84 & 0,09 & 0,06 & 1,18 & 1,92 & 0,07 & 0,02 & 0,07 & 0,06 & 1,56 & 0,12 & 35,10 & 100,04 \\
\hline $\operatorname{MR04}(1,20-1,50 \mathrm{~m})$ & 15,40 & 2,19 & 0,13 & 15,80 & 25,00 & 0,06 & 0,93 & 0,10 & 0,06 & 0,72 & 2,21 & 0,08 & 0,03 & 0,11 & 0,07 & 1,95 & 0,12 & 35,43 & 100,39 \\
\hline $\operatorname{MR05}(1,50-1,80 \mathrm{~m})$ & 13,50 & 2,32 & 0,16 & 17,20 & 27,10 & 0,01 & 0,81 & 0,12 & 0,08 & 0,24 & 1,78 & 0,07 & 0,02 & 0,03 & 0,04 & 0,61 & 0,08 & 36,80 & 100,97 \\
\hline $\operatorname{MR06}(1,80-2,10 \mathrm{~m})$ & 13,30 & 2,04 & 0,16 & 16,90 & 26,50 & 0,00 & 0,86 & 0,10 & 0,06 & 0,23 & 1,71 & 0,05 & 0,01 & 0,02 & 0,04 & 0,53 & 0,03 & 37,30 & 99,84 \\
\hline $\operatorname{MR07}(2,10-2,40 \mathrm{~m})$ & 19,60 & 2,41 & 0,14 & 15,80 & 24,10 & 0,04 & 0,83 & 0,09 & 0,07 & 0,27 & 1,77 & 0,05 & 0,01 & 0,06 & 0,06 & 1,07 & 0,03 & 33,60 & 100,00 \\
\hline $\operatorname{MR08}(2,40-2,60 \mathrm{~m})$ & 15,90 & 2,35 & 0,14 & 16,90 & 25,90 & 0,02 & 0,83 & 0,08 & 0,07 & 0,24 & 1,96 & 0,06 & 0,01 & 0,05 & 0,05 & 0,99 & 0,05 & 34,40 & 100,00 \\
\hline $\operatorname{MR09}(2,60-2,90 \mathrm{~m})$ & 13,90 & 2,39 & 0,15 & 17,40 & 26,90 & 0,00 & 0,80 & 0,09 & 0,06 & 0,22 & 1,80 & 0,03 & 0,01 & 0,04 & 0,04 & 0,74 & 0,04 & 35,30 & 99,91 \\
\hline $\operatorname{MR10}(2,90-3,10 \mathrm{~m})$ & 14,90 & 2,28 & 0,15 & 17,30 & 26,20 & 0,05 & 0,84 & 0,11 & 0,08 & 0,17 & 1,65 & 0,06 & 0,01 & 0,02 & 0,05 & 0,41 & 0,03 & 35,70 & 100,01 \\
\hline $\operatorname{MR11}(3,10-3,40 \mathrm{~m})$ & 13,90 & 2,11 & 0,15 & 17,50 & 27,50 & 0,03 & 0,79 & 0,12 & 0,11 & 0,28 & 1,61 & 0,11 & 0,02 & 0,02 & 0,04 & 0,34 & 0,05 & 35,60 & 100,28 \\
\hline Média & 15,75 & 2,23 & 0,14 & 16,62 & 25,79 & 0,02 & 0,84 & 0,10 & 0,07 & 0,40 & 1,87 & 0,06 & 0,02 & 0,05 & 0,05 & 1,01 & 0,07 & & \\
\hline Erro & 0,65 & 0,05 & 0,00 & 0,24 & 0,37 & 0,01 & 0,02 & 0,00 & 0,00 & 0,09 & 0,07 & 0,01 & 0,00 & 0,01 & 0,00 & $\mathbf{0 , 1 7}$ & 0,01 & & \\
\hline "Desvio Padrão & 2,16 & $\begin{array}{l}\mathbf{0 , 1 5} \\
\end{array}$ & $\overline{0.01}$ & 0,81 & 1,22 & 0,02 & 0,05 & 0,01 & $\overline{0,02}$ & 0,31 & 0,22 & 0,02 & 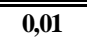 & (2,03 & $\overline{0,01}$ & 0,55 & 0,04 & & \\
\hline
\end{tabular}

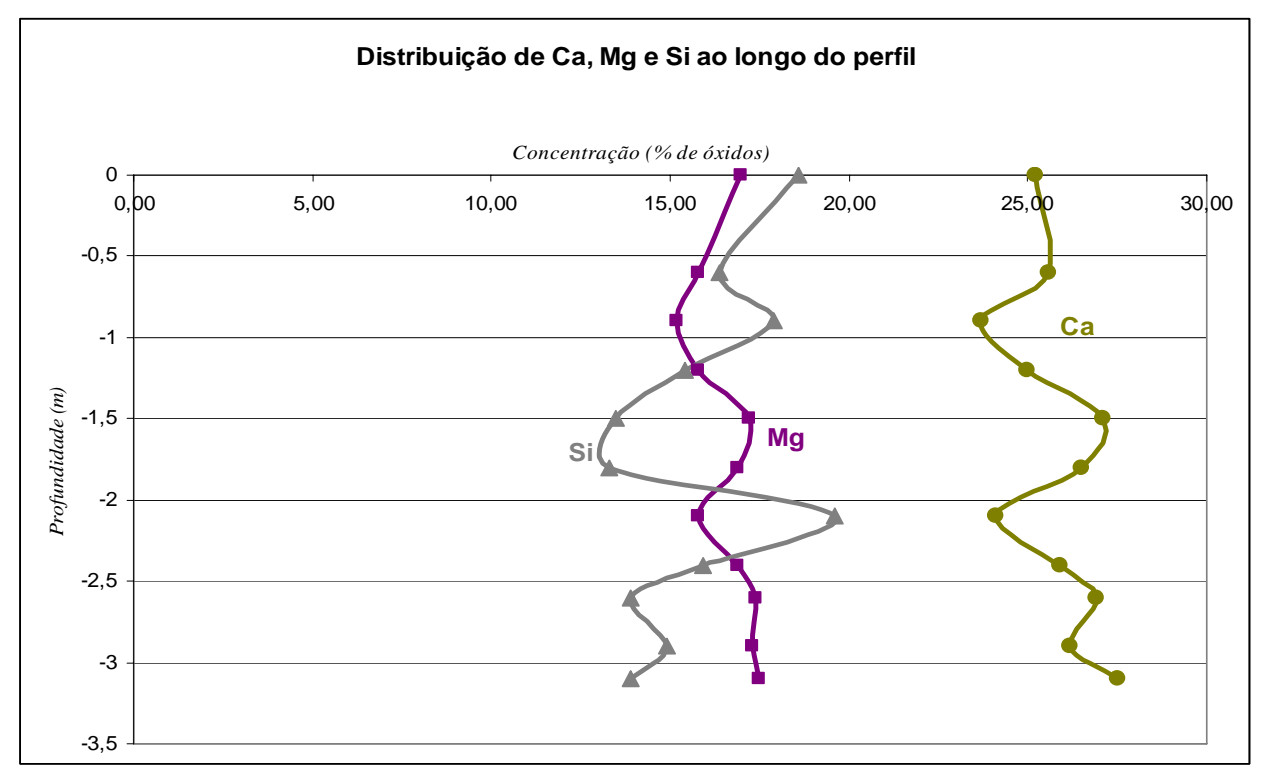

Gráfico 6 - Distribuição de Ca, Mg e Si ao longo do perfil sondado no rejeito da mina do Rocha 
Nestes rejeitos a média de $\mathrm{PbO}$ foi da ordem de $1,01 \% \pm 0,55$, enquanto que para 0 $\mathrm{CuO}, \mathrm{Cr}_{2} \mathrm{O}_{3}$ e $\mathrm{ZnO}$ a média obtida foi inferior a $0,05 \%$, conforme dados da tabela 5 . A tabela 6, exibe os valores de $\mathrm{Pb}, \mathrm{Cu}, \mathrm{Cr}$ e $\mathrm{Zn}$ em mg/kg.

Tabela 6 - Teores de metais pesados detectados no rejeito da mina do Rocha, convertidos para mg/kg

\begin{tabular}{ccccc}
\hline $\begin{array}{c}\text { Amostra } \\
\text { Profundidade }\end{array}$ & $\begin{array}{c}\text { Pb } \\
\text { mg/kg }\end{array}$ & $\begin{array}{c}\text { Zn } \\
\text { mg/kg }\end{array}$ & $\begin{array}{c}\text { Cu } \\
\text { mg/kg }\end{array}$ & $\begin{array}{c}\text { Cr } \\
\text { mg/kg }\end{array}$ \\
\hline \hline MR01 (0,0-0,60m) & 11067,00 & 480,00 & 480,00 & 204,00 \\
MR02 (0,60-0,90m) & 16461,00 & 640,00 & 800,00 & 136,00 \\
MR03 (0,90-1,20m) & 14508,00 & 480,00 & 560,00 & 136,00 \\
MR04 (1,20-1,50m) & 18135,00 & 560,00 & 880,00 & 204,00 \\
MR05 (1,50-1,80m) & 5673,00 & 320,00 & 240,00 & 136,00 \\
MR06 (1,80-2,10m) & 4929,00 & 320,00 & 160,00 & 68,00 \\
MR07 (2,10-2,40m) & 9951,00 & 480,00 & 480,00 & 68,00 \\
MR08 (2,40-2,60m) & 9207,00 & 400,00 & 400,00 & 68,00 \\
MR09 (2,60-2,90m) & 6882,00 & 320,00 & 320,00 & 68,00 \\
MR10 (2,90-3,10m) & 3813,00 & 400,00 & 160,00 & 68,00 \\
MR11 (3,10-3,40m) & 3162,00 & 320,00 & 160,00 & 136,00 \\
\hline \hline Média & $\mathbf{9 4 3 5 , 2 7}$ & $\mathbf{4 2 9 , 0 9}$ & $\mathbf{4 2 1 , 8 2}$ & $\mathbf{1 1 7 , 4 5}$ \\
\hline
\end{tabular}

Segundo os dados da tabela 6, o Pb é o elemento com maior concentração química detectado nestas amostras, sendo sua média de 9.435,27 mg/kg. Tais concentrações ultrapassam os valores de $\mathrm{Pb}(1.000 \mathrm{mg} / \mathrm{kg})$ recomendáveis para resíduos, segundo normas da ABNT (NBR 10.005), indicando que este material enquadra-se na "Classe I" de resíduos sólidos. As médias de concentrações químicas para os elementos $\mathrm{Zn}$ e $\mathrm{Cu}$ foram aproximadamente iguais, sendo de $429,09 \mathrm{mg} / \mathrm{kg}$ para o primeiro e de $421,82 \mathrm{mg} / \mathrm{kg}$ para o segundo (Tabela 6). O Cr, dentre os metais investigados, foi o que exibiu menor concentração química, sendo sua média de $117,45 \mathrm{mg} / \mathrm{kg}$.

No gráfico abaixo se observa que o $\mathrm{Pb}$ concentra-se na porção superficial do perfil sondado, até aproximadamente 1,5 m, sofrendo decréscimo a partir desta profundidade, com aumento pontual nas profundidades de 2,10 a 2,40 m e 2,40 a 2,60 m. Na profundidade de 1,20 até $1,50 \mathrm{~m}$ foi detectado o maior teor de $\mathrm{Pb}$, da ordem de $18.135,00 \mathrm{mg} / \mathrm{kg}$, enquanto que na profundidade de 3,10 até $3,40 \mathrm{~m}$ foi encontrado o menor teor $(3.162,00$ $\mathrm{mg} / \mathrm{kg}$ ), como exibe a tabela 6 e o gráfico 7. 


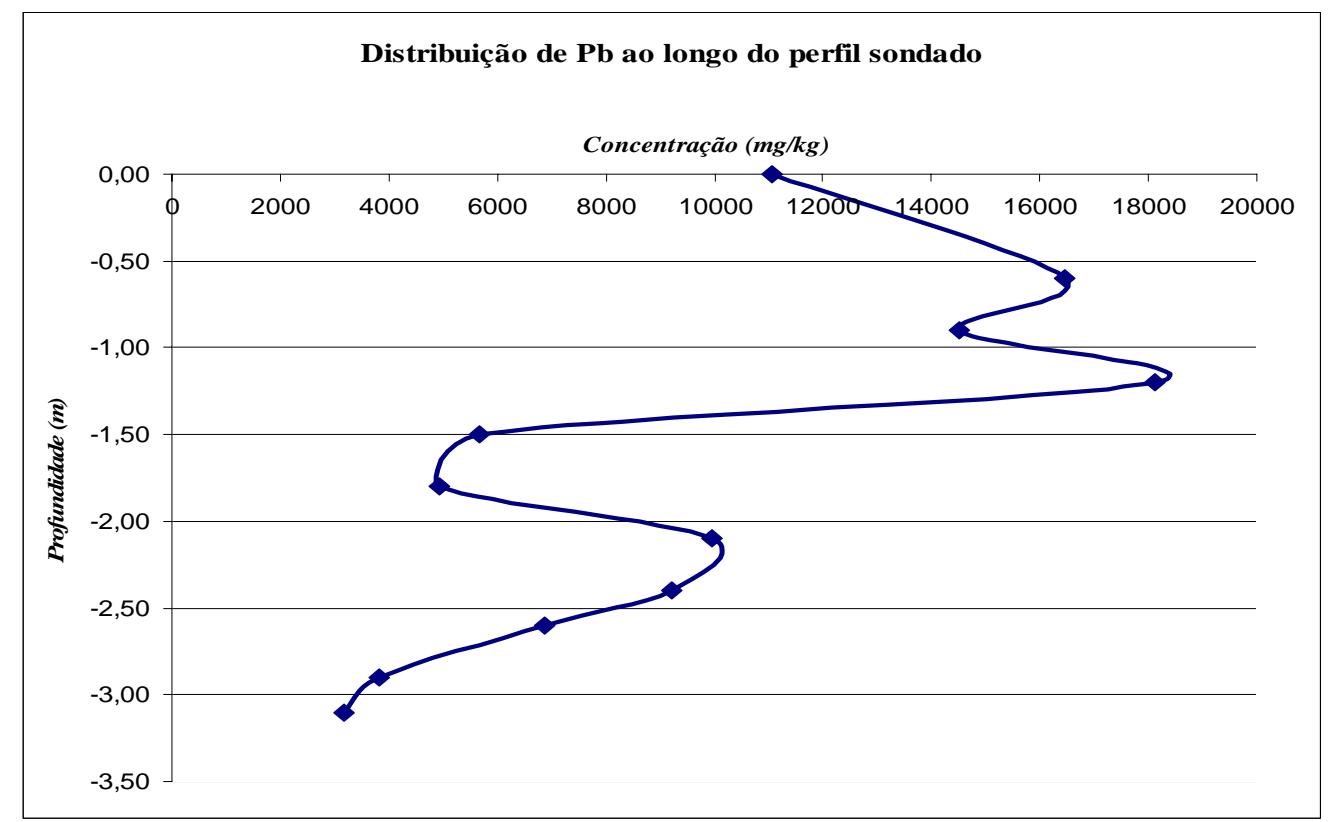

Gráfico 7 - Distribuição dos teores de Pb com a profundidade - rejeito da mina do Rocha

O Cu e Zn apresentam a mesma curva de tendência ao longo do perfil sondado, o aumento de um deles corresponde ao aumento do outro elemento para uma mesma profundidade (Gráfico 8). Estes dois metais concentram-se na porção superior do perfil, principalmente nas profundidades de 0,60 a 0,90 m e 1,20 a 1,50 m, decrescendo a partir de 1,50 m, mesmo comportamento químico observado para Pb (Gráfico 7). Por outro lado, no gráfico 8, nota-se que a concentração de $\mathrm{Cr}$ é basicamente constante ao longo do perfil, com exceção das profundidades de 0,6 m e 1,2 $\mathrm{m}$.

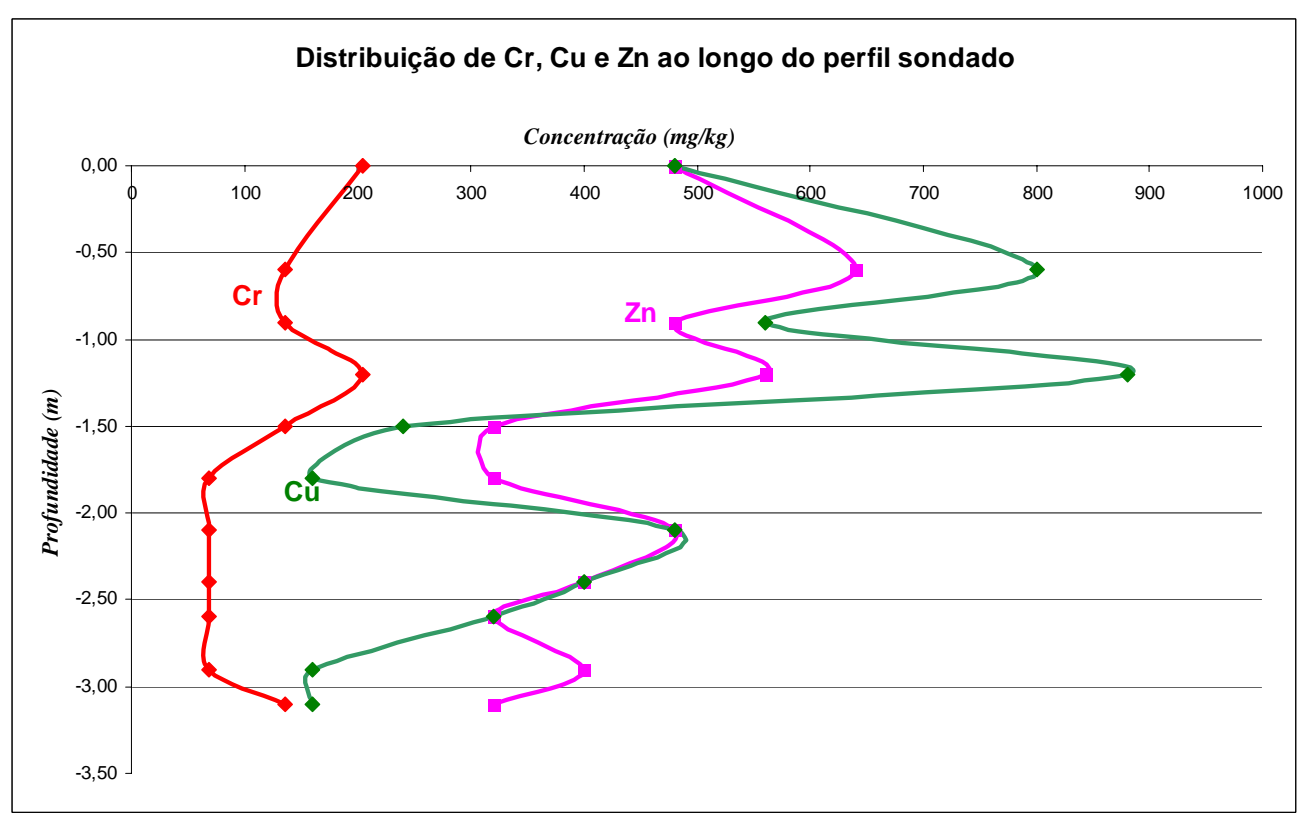

Gráfico 8 - Distribuição dos teores de Cr, Cu e Zn com a profundidade - rejeito da mina do Rocha 
Pelos dados expostos, verifica-se que o $\mathrm{Pb}, \mathrm{Zn}, \mathrm{Cu}$, Fe e Si concentram-se no topo do perfil, tendência de concentração química semelhante ao de um perfil de solo. Estes elementos exibem mobilidade mais baixa que a do $\mathrm{Ca}$ e $\mathrm{Mg}$, estes últimos concentram-se na base por serem elementos químicos os quais diante de condições químicas favoráveis exibem maior mobilidade (Tabela 5).

Para verificar a associação entre os elementos químicos que compõem o rejeito, em um primeiro momento, elaborou-se uma matriz de correlação de Pearson para todo o perfil (Tabela 7). Esta matriz exibe associação positiva entre: "Ca e Mg"; “Mg e Mn"; "Fe e K"; "Fe e Pb"; "Pb e S"; "Pb e Cu"; "Pb e Zn", "Zn e Fe" e "Cu e Zn", para isso foram considerados os valores positivos acima de 0,7 (Tabela 7).

Tabela 7 - Matriz de correlação de Pearson para os elementos detectados no rejeito da Mina do Rocha

\begin{tabular}{|c|c|c|c|c|c|c|c|c|c|c|c|c|c|c|}
\hline \multicolumn{15}{|c|}{ Matriz de correlação dos elementos no perfil analisado na Mina do Rocha } \\
\hline & $\mathrm{Mg}$ & $\mathrm{Si}$ & $\mathrm{Ca}$ & Al & $\mathrm{K}$ & $\mathrm{Fe}$ & $\mathrm{Pb}$ & $P$ & $\mathrm{~s}$ & $\mathrm{Ti}$ & $\mathrm{Cr}$ & $\mathrm{Mn}$ & $\mathrm{Cu}$ & $\mathrm{Zn}$ \\
\hline $\mathrm{Si}$ & $-0,63$ & & & & & & & & & & & & & \\
\hline $\mathrm{Ca}$ & 0,87 & $-0,87$ & & & & & & & & & & & & \\
\hline Al & 0,07 & $-0,03$ & 0,13 & & & & & & & & & & & \\
\hline $\mathrm{K}$ & $-0,61$ & $-0,03$ & $-0,30$ & 0,13 & & & & & & & & & & \\
\hline $\mathrm{Fe}$ & $-0,63$ & 0,30 & $-0,44$ & 0,11 & 0,70 & & & & & & & & & \\
\hline $\mathrm{Pb}$ & $-0,84$ & 0,54 & $-0,71$ & $-0,04$ & 0,65 & 0,92 & & & & & & & & \\
\hline$P$ & 0,56 & $-0,26$ & 0,53 & $-0,08$ & $-0,50$ & $-0,59$ & $-0,62$ & & & & & & & \\
\hline S & $-0,81$ & 0,35 & $-0,66$ & $-0,39$ & 0,42 & 0,49 & 0,71 & $-0,38$ & & & & & & \\
\hline $\mathrm{Ti}$ & 0,39 & $-0,58$ & 0,60 & $-0,09$ & $-0,03$ & $-0,36$ & $-0,45$ & 0,67 & $-0,21$ & & & & & \\
\hline $\mathrm{Cr}$ & $-0,26$ & 0,22 & $-0,21$ & $-0,49$ & 0,14 & 0,51 & 0,56 & 0,02 & 0,44 & 0,17 & & & & \\
\hline $\mathrm{Mn}$ & 0,83 & $-0,63$ & 0,74 & 0,06 & $-0,51$ & $-0,77$ & $-0,88$ & 0,42 & $-0,77$ & 0,45 & $-0,40$ & & & \\
\hline $\mathrm{Cu}$ & $-0,78$ & 0,50 & $-0,64$ & 0,07 & 0,67 & 0,94 & 0,98 & $-0,55$ & 0,62 & $-0,39$ & 0,56 & $-0,86$ & & \\
\hline $\mathrm{Zn}$ & $-0,77$ & 0,63 & $-0,69$ & 0,05 & 0,66 & 0,85 & 0,90 & $-0,45$ & 0,52 & $-0,32$ & 0,48 & $-0,88$ & 0,91 & \\
\hline $\mathrm{Ba}$ & $-0,06$ & $-0,18$ & 0,17 & $-0,29$ & 0,16 & 0,04 & 0,04 & 0,66 & 0,28 & 0,61 & 0,44 & $-0,16$ & 0,08 & 0,09 \\
\hline
\end{tabular}

Segundo esta matriz existe associação positiva entre o $\mathrm{Pb}$ e $\mathrm{Cu}, \mathrm{Pb}$ e $\mathrm{Fe}, \mathrm{Pb}$ e $\mathrm{Zn}$, isto possivelmente indica, que nas porções do perfil de rejeito em que foram encontradas altas concentrações de $\mathrm{Pb}$, também serão encontradas altas concentrações destes outros elementos. Esta correlação já era esperada, uma vez que estes quatro elementos exibiram comportamento químico semelhante ao longo do perfil analisado (Tabela 5). Também, existe correlação positiva entre $\mathrm{Cu}$ e $\mathrm{Zn}$, ou seja, profundidades com alta concentração de $\mathrm{Cu}$ também terão altas concentrações de Zn. Além da associação com o $\mathrm{Cu}$, o Zn também exibe correlação positiva com o Fe.

Como complemento dos estudos realizados na DRX e FRX, foram obtidas análises químicas pontuais qualitativas em MEV/EDS, as quais confirmaram a presença de $\mathrm{Pb}$ e $\mathrm{Cu}$ 
em meio a uma matriz carbonática, conforme visualizado nos espectros EDS das figuras 20 e 21.

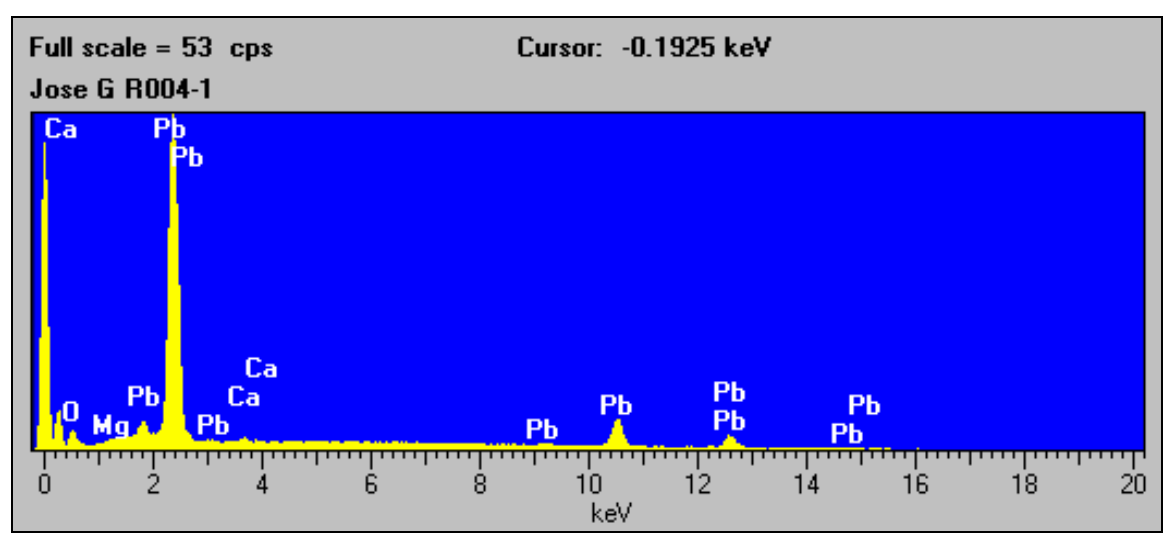

Figura 20 - Espectro EDS da amostra de rejeito do concentrado da Mina do Rocha

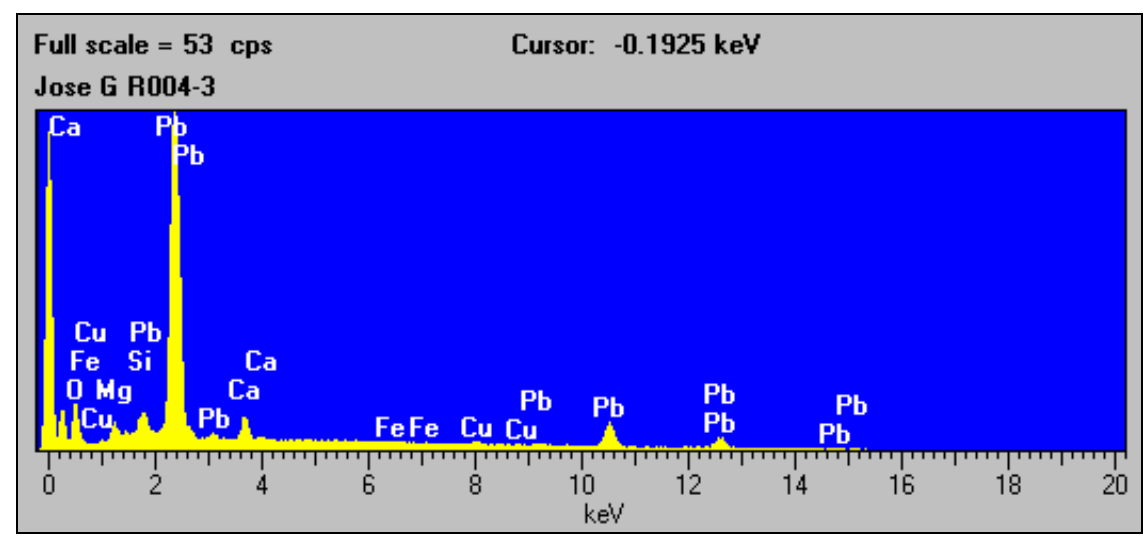

Figura 21 - Espectro EDS da amostra de rejeito do concentrado da Mina do Rocha

Nesta amostra foram realizados testes de lixiviação, segundo a norma NBR 10.005 (ABNT, 1987a), o qual demonstrou que o teor de Pb ultrapassa o limite fixado em 32 vezes (o teor de $\mathrm{Pb}$ obtido no extrato lixiviado foi de $164 \mathrm{mg} / \mathrm{L}$, sendo o teor fixado em 5,0 mg/L), conduzindo a classificação deste rejeito como "Classe I".

\subsubsection{Considerações sobre os resultados obtidos}

De modo geral, a caracterização química e física das amostras de rejeito do concentrado da mina do Rocha permitiu comprovar que este material é fino (resultado do processo de cominuição para liberação do minério) e é composto principalmente por Ca e Mg (reflexos do protominério extraído e tratado nesta mina), apresentando altos teores de $\mathrm{Pb}$ (média de 9.435,2 mg/kg).

Como já abordado em outros trabalhos (FERREIRA, 1998, LEAL, 2001; CASSIANO, 2001 e FRANCHI, 2004), esta pilha apresenta padrões de distribuição mineral, química e 
granulométrica, que confirmam processo de degradação mineral dos minerais primários correspondentes as mineralizações de $\mathrm{Pb}$ e metais associados. Também, foi verificada nesta sondagem mudança de comportamento granulométrico, químico e mineral, a partir da profundidade de 1,35 m, com já havia sido relatado em Leal (2001) e Franchi (2004). Tal variação pode ser resultado de histórias deposicionais distintas destes resíduos (podendo ter ocorrido mudanças nos processos minerais de concentração ou tratamento de minérios provenientes de diferentes setores da mina).

Nesta pilha de rejeito, observa-se que o $\mathrm{Fe}$ e $\mathrm{Si}$ não possuem tendência à mobilidade ao longo do perfil ao contrário do que ocorre com o Ca e $\mathrm{Mg}$, isto já foi verificado anteriormente por Ferreira (1998), Leal (2001); Cassiano (2001) e Franchi (2004), o que demonstra que este perfil de origem tecnogênica comporta-se como um perfil de solo, nos primeiros metros da pilha. Na pesquisa realizada por Cassiano (2001), neste mesmo material, o teor médio de $\mathrm{Pb}$ detectado foi da ordem de 13.000 ppm, enquanto que neste trabalho este teor foi da ordem de $9.435,2 \mathrm{mg} / \mathrm{kg}$, tal variação pode estar ligada ao equipamento empregado na análise química total, como também, à técnica de amostragem e preparação das amostras.

Segundo Cassiano (2001), estes rejeitos também foram classificados como resíduos classe I, perigosos, a partir de ensaios de lixiviação (NBR 10.005) com material coletado nesta pilha. Esta classificação baseou-se no teor de $\mathrm{Pb}$ e $\mathrm{Cr}$ total, que ultrapassaram os valores fixados por esta norma, como ocorrido na presente pesquisa. Mesmo sendo estes rejeitos classificados como perigosos, cabe ressaltar que a predominância de $\mathrm{Ca}$ conduz para a ocorrência de mecanismos naturais de atenuação, elevando o pH da pilha à alcalinidade e impedindo a ocorrência da liberação destes metais pela formação de drenagem ácida.

\subsubsection{Rejeitos do concentrado da Plumbum}

As amostras de rejeito da Plumbum coletadas no patamar $2 \mathrm{~m}$ não exibiram variações granulométricas com a profundidade. Conforme anteriormente explicado no capítulo referente aos materiais e métodos, estes rejeitos foram coletados em vários pontos de uma mesma camada (de 20 em $20 \mathrm{~cm}$, até atingir $2 \mathrm{~m}$ ) e para cada camada as amostras foram compostas, gerando desta maneira uma amostra representativa por extrato. Para todos os extratos observa-se composição na fração areia, com média da ordem de 86,66\% $\pm 4,35$. As frações silte e argila perfazem, respectivamente, $11,24 \% \pm 4,58$ e 2,10\% $\pm 1,37$, deste rejeito (Tabela 8 ). 
Tabela 8 - Distribuição granulométrica das amostras de rejeito do concentrado da Plumbum (\%)

\begin{tabular}{ccccc}
\hline Amostra/Profundidade & $\begin{array}{c}\text { Areia } \\
\text { \% }\end{array}$ & $\begin{array}{c}\text { Silte } \\
\%\end{array}$ & $\begin{array}{c}\text { Argila } \\
\text { \% }\end{array}$ & $\begin{array}{c}\text { Fechamento } \\
\%\end{array}$ \\
\hline \hline MP01 (0,0-0,20m) & 88,50 & 9,50 & 2,00 & $\mathbf{1 0 0 , 0 0}$ \\
MP02 (0,20-0,40m) & 86,40 & 10,60 & 3,00 & $\mathbf{1 0 0 , 0 0}$ \\
MP03 (0,40-0,60m) & 86,00 & 9,00 & 5,00 & $\mathbf{1 0 0 , 0 0}$ \\
MP04 (0,60-0,80m) & 86,00 & 10,00 & 4,00 & $\mathbf{1 0 0 , 0 0}$ \\
MP05 (0,80-1,00m) & 88,20 & 8,80 & 3,00 & $\mathbf{1 0 0 , 0 0}$ \\
MP06 (1,00-1,20m) & 88,50 & 9,50 & 2,00 & $\mathbf{1 0 0 , 0 0}$ \\
MP07 (1,20-1,40m) & 88,20 & 11,80 & 0,00 & $\mathbf{1 0 0 , 0 0}$ \\
MP08 (1,40-1,60m) & 94,90 & 4,10 & 1,00 & $\mathbf{1 0 0 , 0 0}$ \\
MP09 (1,60-1,80m) & 79,90 & 19,10 & 1,00 & $\mathbf{1 0 0 , 0 0}$ \\
MP10 (1,80-2,00m) & 79,98 & 19,02 & 1,00 & $\mathbf{1 0 0 , 0 0}$ \\
\hline \hline Média & $\mathbf{8 6 , 6 6}$ & $\mathbf{1 1 , 2 4}$ & $\mathbf{2 , 1 0}$ & \\
\hline \hline Erro & $\mathbf{1 , 3 8}$ & $\mathbf{1 , 4 5}$ & $\mathbf{0 , 4 3}$ & \\
\hline \hline Desvio Padrão & $\mathbf{4 , 3 5}$ & $\mathbf{4 , 5 8}$ & $\mathbf{1 , 3 7}$ & \\
\hline
\end{tabular}

Na fração areia há predomínio das frações areia muito fina (média de 35,03\% \pm 9,16) e areia fina (média de $32,56 \% \pm 3,10$ ), reflexo dos processos de cominuição realizados para liberação do minério (Tabela 9). Até a camada de 0,80 m há predomínio da fração areia fina, a partir desta profundidade os rejeitos passam a apresentar granulometria na faixa de areia muito fina, conforme exibe tabela 9.

Tabela 9 - Distribuição granulométrica da fração areia - rejeito do concentrado da Plumbum (\%)

\begin{tabular}{lccccc}
\hline & $\begin{array}{c}\text { Areia } \\
\text { Muito Grossa } \\
\text { Amostra/Profundidade }\end{array}$ & $\begin{array}{c}\text { Areia } \\
\text { Grossa } \\
\text { \% }\end{array}$ & $\begin{array}{c}\text { Areia } \\
\text { Média } \\
\text { \% }\end{array}$ & $\begin{array}{c}\text { Areia } \\
\text { Fina } \\
\text { \% }\end{array}$ & $\begin{array}{c}\text { Areia } \\
\text { Muito Fina } \\
\text { \% }\end{array}$ \\
\hline \hline MP01 (0,0-0,20m) & 0,10 & 2,70 & 23,00 & 36,20 & 26,50 \\
MP02 (0,20-0,40m) & 0,00 & 0,70 & 24,10 & 35,50 & 26,00 \\
MP03 (0,40-0,60m) & 0,10 & 2,70 & 23,00 & 36,00 & 26,70 \\
MP04 (0,60-0,80m) & 0,00 & 0,70 & 29,90 & 31,70 & 23,70 \\
MP05 (0,80-1,00m) & 0,00 & 2,30 & 14,70 & 34,50 & 36,70 \\
MP06 (1,00-1,20m) & 0,30 & 4,20 & 11,70 & 31,50 & 40,80 \\
MP07 (1,20-1,40m) & 0,10 & 0,80 & 10,10 & 32,50 & 44,80 \\
MP08 (1,40-1,60m) & 0,00 & 0,50 & 10,80 & 32,30 & 51,30 \\
MP09 (1,60-1,80m) & 0,10 & 1,00 & 14,30 & 27,70 & 36,90 \\
MP10 (1,80-2,00m) & 0,10 & 1,00 & 14,30 & 27,70 & 36,90 \\
\hline \hline Média & $\mathbf{0 , 0 8}$ & $\mathbf{1 , 6 6}$ & $\mathbf{1 7 , 5 9}$ & $\mathbf{3 2 , 5 6}$ & $\mathbf{3 5 , 0 3}$ \\
\hline \hline Erro & $\mathbf{0 , 0 3}$ & $\mathbf{0 , 3 9}$ & $\mathbf{2 , 1 6}$ & $\mathbf{0 , 9 8}$ & $\mathbf{2 , 9 0}$ \\
\hline \hline Desvio Padrão & $\mathbf{0 , 0 9}$ & $\mathbf{1 , 2 4}$ & $\mathbf{6 , 8 3}$ & $\mathbf{3 , 1 0}$ & $\mathbf{9 , 1 6}$ \\
\hline
\end{tabular}

As identificações mineralógicas por DRX evidenciaram a presença de quartzo, barita, calcita/dolomita e galena. Secundariamente, também foram identificadas muscovita, biotita e flogopita. 
Quanto à composição química, em \% de óxidos, verifica-se o predomínio de $\mathrm{SiO}_{2}$ (média de 32,47\% \pm 8,19), $\mathrm{SO}_{3}$ (média de 22,60\% \pm 9,19), $\mathrm{Ba}$ (média de 12,50\% $\pm 5,30$ ), $\mathrm{Fe}$ (média de $7,01 \% \pm 1,02$ ) e Ca (média de $6,74 \% \pm 0,98$ ), sendo que os outros elementos apresentam-se em concentrações inferiores a média de $6 \%\left(\mathrm{Al}_{2} \mathrm{O}_{3}, \mathrm{MnO}, \mathrm{MgO}, \mathrm{Na}_{2} \mathrm{O}, \mathrm{K}_{2} \mathrm{O}\right.$, $\mathrm{P}_{2} \mathrm{O}_{5}$ e $\mathrm{TiO}_{2}$ ). Neste rejeito, também foram detectados $\mathrm{ZnO}$ (média de 1,10\% $\pm 0,39$ ) e $\mathrm{PbO}$ (média de 0,66\% $\pm 0,23$ ), conforme exposto na tabela 10 .

Tabela 10 - Análise química total das amostras de rejeito da Plumbum - FRX - \% de óxidos

\begin{tabular}{|c|c|c|c|c|c|c|c|c|c|c|c|c|c|c|c|c|}
\hline $\begin{array}{c}\text { Amostra } \\
\text { Profundidade }\end{array}$ & $\begin{array}{c}\mathrm{SiO}_{2} \\
\%\end{array}$ & $\begin{array}{c}\mathrm{Al}_{2} \mathrm{O}_{3} \\
\%\end{array}$ & $\begin{array}{c}\mathrm{MnO} \\
\%\end{array}$ & $\underset{\%}{\mathrm{MgO}}$ & $\begin{array}{c}\mathrm{CaO} \\
\%\end{array}$ & $\begin{array}{c}\mathrm{Na}_{2} \mathrm{O} \\
\%\end{array}$ & $\begin{array}{c}\mathrm{K}_{2} \mathrm{O} \\
\%\end{array}$ & $\begin{array}{c}\mathrm{TiO}_{2} \\
\%\end{array}$ & $\begin{array}{c}\mathbf{P}_{2} \mathbf{O}_{5} \\
\%\end{array}$ & $\begin{array}{c}\mathrm{SO}_{3} \\
\%\end{array}$ & $\begin{array}{c}\mathbf{F e}_{2} \mathbf{O}_{3} \\
\%\end{array}$ & $\begin{array}{c}\mathrm{BaO} \\
\%\end{array}$ & $\begin{array}{c}\mathrm{ZnO} \\
\%\end{array}$ & $\begin{array}{c}\text { PbO } \\
\%\end{array}$ & $\begin{array}{r}\text { PF } \\
\%\end{array}$ & $\begin{array}{c}\text { Fechamento } \\
\%\end{array}$ \\
\hline MP01 (0,0-0,20m) & 32,28 & 5,78 & 0,21 & 5,13 & 5,73 & 0,57 & 1,87 & 0,28 & 0,06 & 23,50 & 8,34 & 11,10 & 1,94 & 1,25 & 8,83 & 106,87 \\
\hline MP02 $(0,20-0,40 m)$ & 40,37 & 7,22 & 0,23 & 5,97 & 7,17 & 0,47 & 2,49 & 0,33 & 0,07 & 14,26 & 7,15 & 7,52 & 1,34 & 0,85 & 7,79 & 103,23 \\
\hline MP03 $(0,40-0,60 \mathrm{~m})$ & 42,28 & 7,59 & 0,24 & 6,16 & 8,18 & 0,45 & 2,71 & 0,33 & 0,07 & 11,47 & 6,09 & 6,39 & 0,94 & 0,62 & 8,52 & 102,04 \\
\hline MP04 (0,60-0,80m) & 44,34 & 8,10 & 0,19 & 5,61 & 6,99 & 0,35 & 3,12 & 0,36 & 0,07 & 11,53 & 5,52 & 6,86 & 0,70 & 0,48 & 8,28 & 102,50 \\
\hline $\operatorname{MP05}(0,80-1,00 m)$ & 29,41 & 5,10 & 0,15 & 4,59 & 5,88 & 0,42 & 1,77 & 0,26 & 0,05 & 28,56 & 7,83 & 13,79 & 1,24 & 0,66 & 9,49 & 109,20 \\
\hline MP06 (1,00-1,20m) & 19,10 & 3,25 & 0,09 & 3,88 & 5,05 & 0,44 & 1,12 & 0,22 & 0,04 & 37,52 & 6,34 & 23,07 & 1,29 & 0,56 & 7,66 & 109,63 \\
\hline $\operatorname{MP07}(1,20-1,40 m)$ & 24,48 & 4,31 & 0,15 & 4,77 & 6,63 & 0,39 & 1,48 & 0,24 & 0,05 & 29,45 & 7,26 & 18,20 & 1,22 & 0,66 & 8,95 & 108,24 \\
\hline $\operatorname{MP08}(1,40-1,60 \mathrm{~m})$ & 25,54 & 4,47 & 0,15 & 4,62 & 6,57 & 0,33 & 1,60 & 0,26 & 0,06 & 32,87 & 8,64 & 15,19 & 0,68 & 0,52 & 9,33 & 110,83 \\
\hline $\operatorname{MP09}(1,60-1,80 \mathrm{~m})$ & 32,27 & 5,87 & 0,19 & 5,42 & 7,84 & 0,34 & 2,15 & 0,31 & 0,07 & 19,27 & 6,68 & 11,72 & 0,76 & 0,50 & 7,64 & 101,03 \\
\hline $\operatorname{MP10}(1,80-2,00 \mathrm{~m})$ & 34,64 & 6,38 & 0,18 & 5,01 & 7,35 & 0,32 & 2,12 & 0,38 & 0,07 & 18,01 & 6,28 & 10,78 & 0,86 & 0,52 & 7,53 & 100,43 \\
\hline Média & 32,47 & $5,5,80$ & 0,18 & $\overline{5,12}$ & 6,74 & 0,41 & 2,04 & 0,30 & 0,06 & 22,60 & $7 \overline{7,01}$ & 12,50 & $1,1,10$ & 0,66 & & \\
\hline Erro & 2,59 & 0,49 & 0,01 & 0,22 & 0,31 & $\overline{0,02}$ & 0,19 & $\overline{0,02}$ & 0,00 & 2,90 & 0,32 & 1,68 & 0,12 & $\overline{0,07}$ & & \\
\hline "Desvio Padrão & 8,19 & 1,56 & 0,04 & $\overline{0,69}$ & 0,98 & $\overline{0,08}$ & $\overline{0,60}$ & 0,05 & 0,01 & 9,19 & 1,02 & 5,30 & $\overline{0,39}$ & 0,23 & & \\
\hline
\end{tabular}

Os dados referentes aos teores de metais pesados foram convertidos para $\mathrm{mg} / \mathrm{kg}$ (Tabela 11). Dos metais investigados, o Zn exibiu a maior média de concentração química (8.817 mg/kg), seguido do $\mathrm{Pb}$ (média de $6.366,70 \mathrm{mg} / \mathrm{kg}$ ). O teor médio de Cu foi da ordem de $110,90 \mathrm{mg} / \mathrm{kg}$ e o de $\mathrm{Cr}$ foi de $42,10 \mathrm{mg} / \mathrm{kg}$ (Tabela 11).

Tabela 11 - Teores de metais pesados e do Ba detectados no rejeito da Plumbum (mg/kg)

\begin{tabular}{lccccc}
\hline $\begin{array}{c}\text { Amostra } \\
\text { Profundidade }\end{array}$ & $\begin{array}{c}\text { Pb } \\
\mathbf{m g} / \mathbf{k g}\end{array}$ & $\begin{array}{c}\mathbf{Z n} \\
\mathbf{m g} / \mathbf{k g}\end{array}$ & $\begin{array}{c}\mathbf{C u} \\
\mathbf{m g} / \mathbf{k g}\end{array}$ & $\begin{array}{c}\mathbf{C r} \\
\mathbf{m g} / \mathbf{k g}\end{array}$ & $\begin{array}{c}\text { Ba } \\
\mathbf{m g} / \mathbf{k g}\end{array}$ \\
\hline \hline MP01 (0,0-0,20m) & 12034,00 & 15623,00 & 139,00 & 48,00 & 99440,00 \\
MP02 (0,20-0,40m) & 8159,00 & 10767,00 & 94,00 & 31,00 & 67374,00 \\
MP03 (0,40-0,60m) & 5946,00 & 7546,00 & 85,00 & 35,00 & 57226,00 \\
MP04 (0,60-0,80m) & 4607,00 & 5601,00 & 73,00 & 43,00 & 61462,00 \\
MP05 (0,80-1,00m) & 6400,00 & 9995,00 & 91,00 & 43,00 & 123469,00 \\
MP06 (1,00-1,20m) & 5404,00 & 10349,00 & 100,00 & 31,00 & 206602,00 \\
MP07 (1,20-1,40m) & 6337,00 & 9805,00 & 114,00 & 35,00 & 163040,00 \\
MP08 (1,40-1,60m) & 5021,00 & 5476,00 & 108,00 & 51,00 & 136090,00 \\
MP09 (1,60-1,80m) & 4790,00 & 6100,00 & 129,00 & 37,00 & 104969,00 \\
MP10 (1,80-2,00m) & 4969,00 & 6908,00 & 176,00 & 67,00 & 96570,00 \\
\hline \hline LD & $\mathbf{5 , 0 0}$ & $\mathbf{1 , 0 0}$ & $\mathbf{2 , 0 0}$ & $\mathbf{2 , 0 0}$ & $\mathbf{1 7 , 0 0}$ \\
\hline \hline Média & $\mathbf{6 3 6 6 , 7 0}$ & $\mathbf{8 8 1 7 , 0 0}$ & $\mathbf{1 1 0 , 9 0}$ & $\mathbf{4 2 , 1 0}$ & $\mathbf{1 1 1 6 2 4 , 2 0}$ \\
\hline \hline
\end{tabular}

LD: Limite de Detecção do Aparelho 
O rejeito da Plumbum é notadamente rico em Ba (média de 111.624,20 mg/kg), importante constituinte dos minérios do tipo "Perau" que foram beneficiados na usina homônima, localizada nas proximidades da área onde foram depositados estes rejeitos.

Ao longo do patamar $2 \mathrm{~m}, \mathrm{~Pb}$ e $\mathrm{Zn}$ apresentaram curvas de tendência de concentração química semelhantes, como pode ser observado no gráfico 9 , exceto para as camadas entre 1,0 m e 2,0 m. Estes elementos concentram-se, principalmente na camada superficial da pilha de rejeitos, de 0 a $20 \mathrm{~cm}$, onde foram detectados os maiores teores médios (Gráfico 9). O menor teor médio detectado para estes dois metais foi na camada de 1,60 a 1,80 m (Tabela 11 e Gráfico 9).

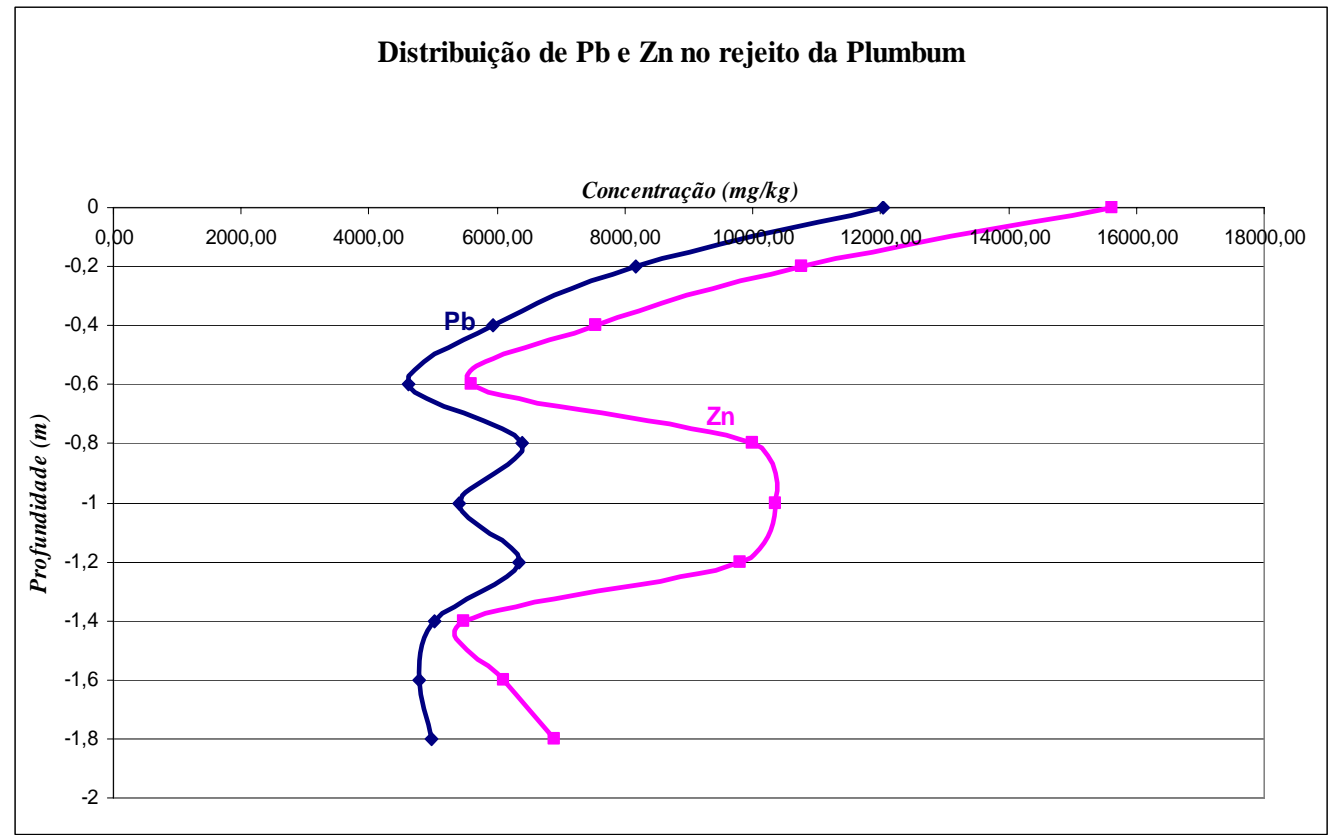

Gráfico 9 - Distribuição dos teores de $\mathrm{Pb}$ e Zn nas diversas camadas do patamar 2 m - rejeito da Plumbum

O Cr e Cu exibiram tendência de concentração química inversamente proporcionais em algumas camadas deste patamar de $2 \mathrm{~m}$, camadas estas de: 0,20-0,40 m, 0,40-0,60 m, 0,8-1,0 m, 1,20-1,40 m e 1,40-1,60 m, conforme observado no gráfico 10. Os maiores teores médios detectados para estes dois metais foram observados nas camadas de 1,80-2,00 m e 0,0-0,20 m (Tabela 11 e Gráfico 10). 


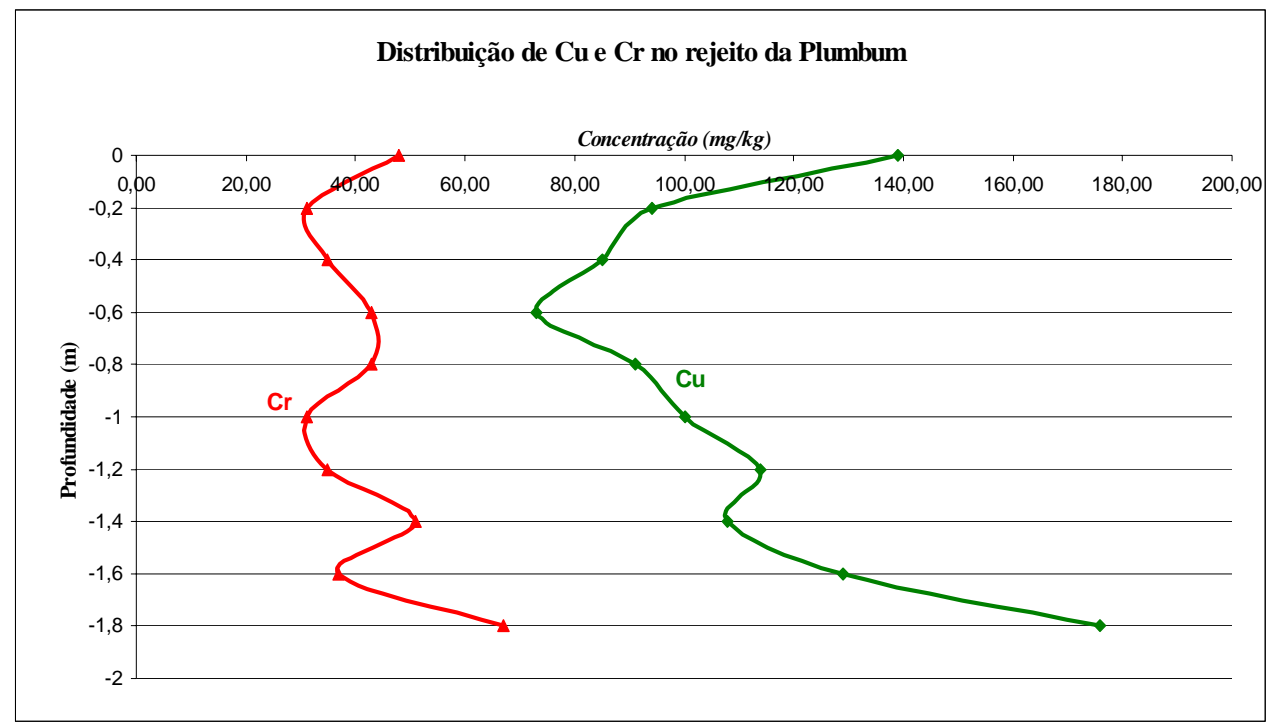

Gráfico 10 - Distribuição dos teores de Cr e Cu nas diversas camadas do patamar 2 m - rejeito da Plumbum

No gráfico 11, observa-se tendência de concentração de Ba semelhante ao do $S$, para o patamar de $2 \mathrm{~m}$ dos rejeitos da Plumbum. Estes dois elementos concentram-se nas camadas medianas, sendo que na profundidade de $1,0 \mathrm{~m}$ foi detectado a maior concentração química para estes dois elementos (Gráfico 11).

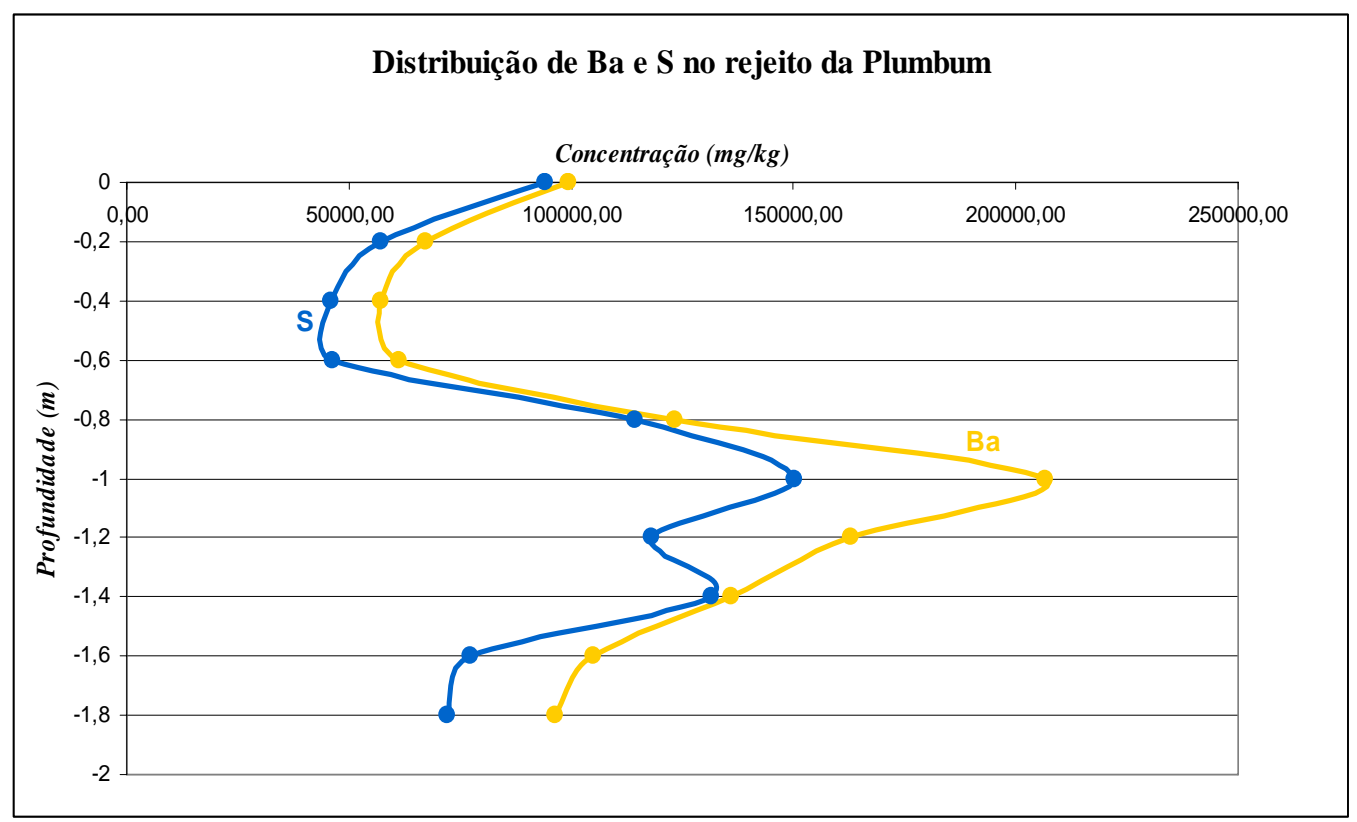

Gráfico 11 - Distribuição do teor de Ba e S nas diversas camadas do patamar 2m - rejeito da Plumbum

Pelos dados expostos, verifica-se serem $\mathrm{Pb}$ e $\mathrm{Zn}$ concentrados nas primeiras camadas desta pilha de rejeitos e que os quatro metais pesados aqui investigados sofrem oscilações de um patamar para outro, até o nível de $2 \mathrm{~m}$ (Tabela 11), possivelmente refletindo distintas épocas de deposição destes rejeitos (isso explica a variação da 
concentração de uma para outra) e proveniências diversas do minério beneficiado que gerou este resíduo. Para verificar a possibilidade de correlação entre os elementos químicos que compõem o rejeito, em um primeiro momento, elaborou-se uma matriz de correlação de Pearson (Tabela 12), sendo considerados os valores positivos acima de 0,8.

Tabela 12 - Matriz de correlação de Pearson para os elementos detectados no rejeito da Plumbum

\begin{tabular}{|c|c|c|c|c|c|c|c|c|c|c|c|c|c|}
\hline \multicolumn{14}{|c|}{ Matriz de correlação dos elementos no perfil de rejeitos da Plumbum } \\
\hline & $\mathrm{Mg}$ & Si & $\mathrm{Ca}$ & Al & K & $\mathrm{Fe}$ & $P b$ & $P$ & $S$ & $\mathrm{Ti}$ & $\mathrm{Mn}$ & $Z n$ & $\mathrm{Ba}$ \\
\hline Mg & 1,00 & & & & & & & & & & & & \\
\hline $\mathrm{Si}$ & 0,92 & 1,00 & & & & & & & & & & & \\
\hline $\mathrm{Ca}$ & 0,81 & 0,68 & 1,00 & & & & & & & & & & \\
\hline Al & 0,91 & 1,00 & 0,70 & 1,00 & & & & & & & & & \\
\hline K & 0,88 & 0,98 & 0,70 & 0,98 & 1,00 & & & & & & & & \\
\hline $\mathrm{Fe}$ & $-0,33$ & $-0,46$ & $-0,41$ & $-0,47$ & $-0,53$ & 1,00 & & & & & & & \\
\hline $\mathrm{Pb}$ & 0,14 & 0,05 & $-0,33$ & 0,04 & $-0,09$ & 0,52 & 1,00 & & & & & & \\
\hline $\mathrm{P}$ & 0,86 & 0,85 & 0,85 & 0,87 & 0,84 & $-0,30$ & $-0,06$ & 1,00 & & & & & \\
\hline$S$ & $-0,94$ & $-0,97$ & $-0,78$ & $-0,98$ & $-0,95$ & 0,53 & $-0,02$ & $-0,89$ & 1,00 & & & & \\
\hline $\mathrm{Ti}$ & 0,73 & 0,86 & 0,72 & 0,88 & 0,85 & $-0,53$ & $-0,15$ & 0,90 & $-0,89$ & 1,00 & & & \\
\hline $\mathrm{Mn}$ & 0,95 & 0,86 & 0,71 & 0,86 & 0,78 & $-0,12$ & 0,37 & 0,84 & $-0,88$ & 0,69 & 1,00 & & \\
\hline $\mathrm{Zn}$ & $-0,15$ & $-0,21$ & $-0,58$ & $-0,23$ & $-0,34$ & 0,42 & 0,91 & $-0,40$ & 0,23 & $-0,39$ & 0,05 & 1,00 & \\
\hline $\mathrm{Ba}$ & $-0,92$ & $-0,97$ & $-0,71$ & $-0,97$ & $-0,93$ & 0,26 & $-0,14$ & $-0,90$ & 0,94 & $-0,84$ & $-0,92$ & 0,18 & 1,00 \\
\hline
\end{tabular}

A matriz de correlação exposta acima, apresenta associação positiva entre "Pb versus Zn", ou seja, o aumento de um destes elementos implica no aumento do outro, como foi observado no gráfico 9, onde estes exibiram curva de tendência química semelhante. Também foram verificadas correlações positivas do "Ca versus Mg", "Si versus Al", "S versus Ba", sendo estas as mais significativas.

Nas análises realizadas em MEV foi revelada a presença de concreções com tamanhos variados e formas arredondadas a sub-arredondadas, ao longo do patamar 2,0 m (Figura 22). Este material consiste em aglomerados de minerais, unidos por uma matriz carbonática, provavelmente oriunda da dissolução de minerais carbonáticos presentes nesta pilha de rejeitos. Estas concreções são compostas, principalmente por $\mathrm{Ca}$ e $\mathrm{Si}$ e secundariamente por: Ba, Fe, S e Zn (Figuras 23 e 24). 


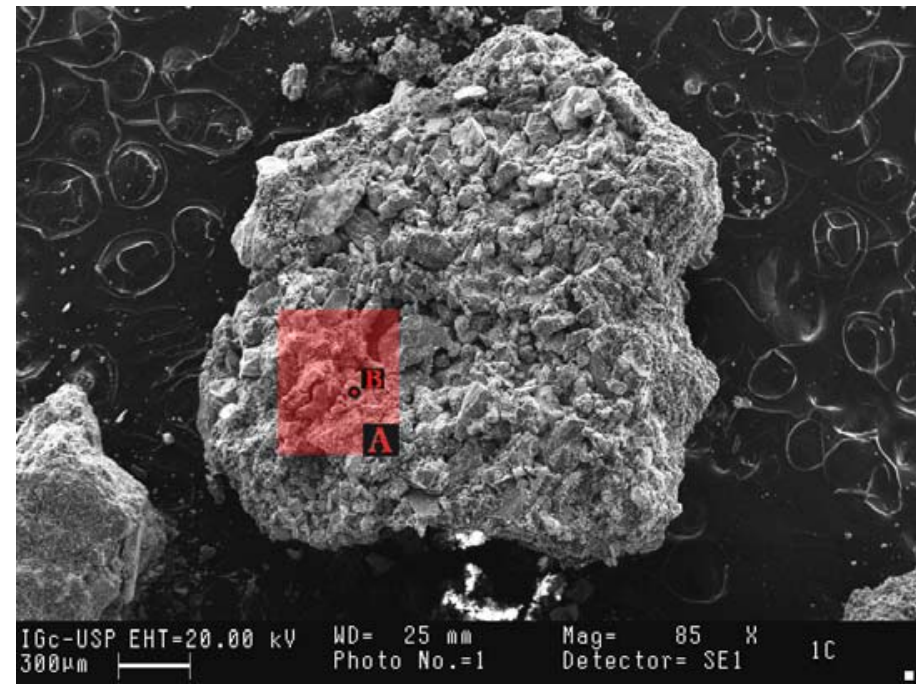

Figura 22 - Concreção detectada nos rejeitos da Plumbum. (Imagem com elétron retro-espalhado)

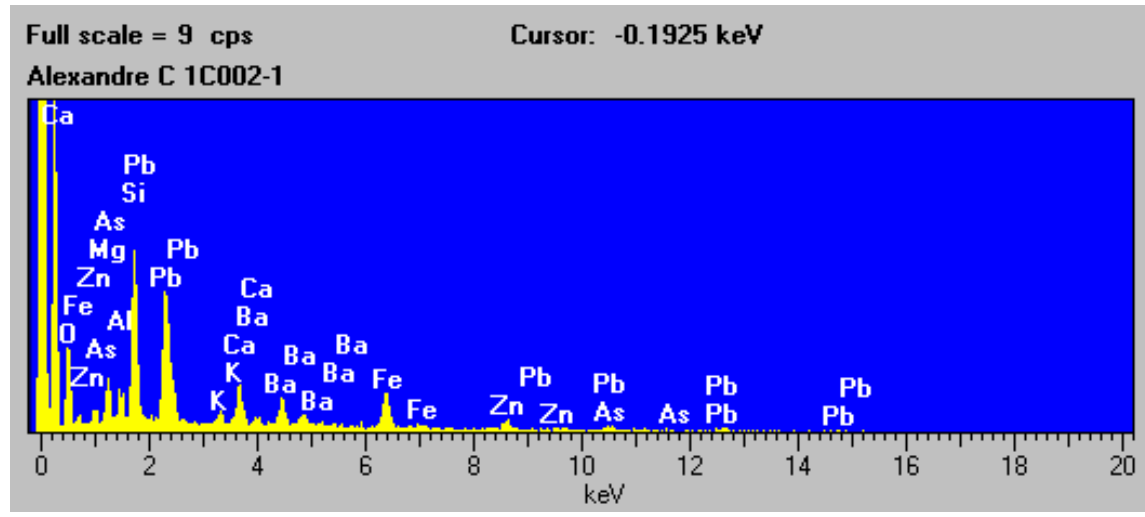

Figura 23 - Espectro EDS da área A da Figura 22

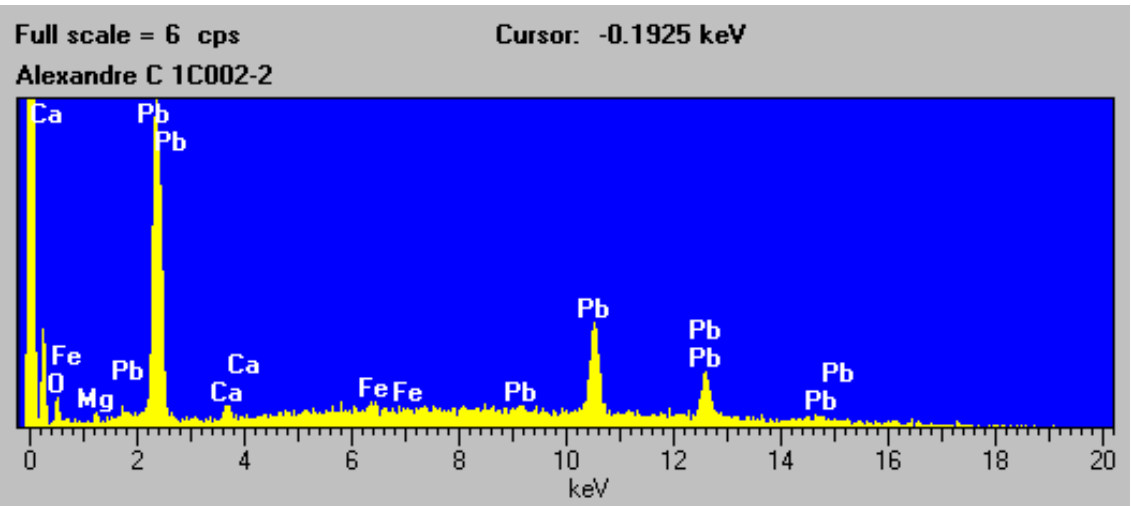

Figura 24 - Espectro EDS da área B da Figura 22

Além das concreções, foi possível comprovar em MEV/EDS, a presença de As, juntamente com $\mathrm{Fe}$ e $\mathrm{Al}$ (Figura 25). Esta partícula exibe morfologia de cristalização sugerindo ser o mineral arsenopirita (Figura 26). 


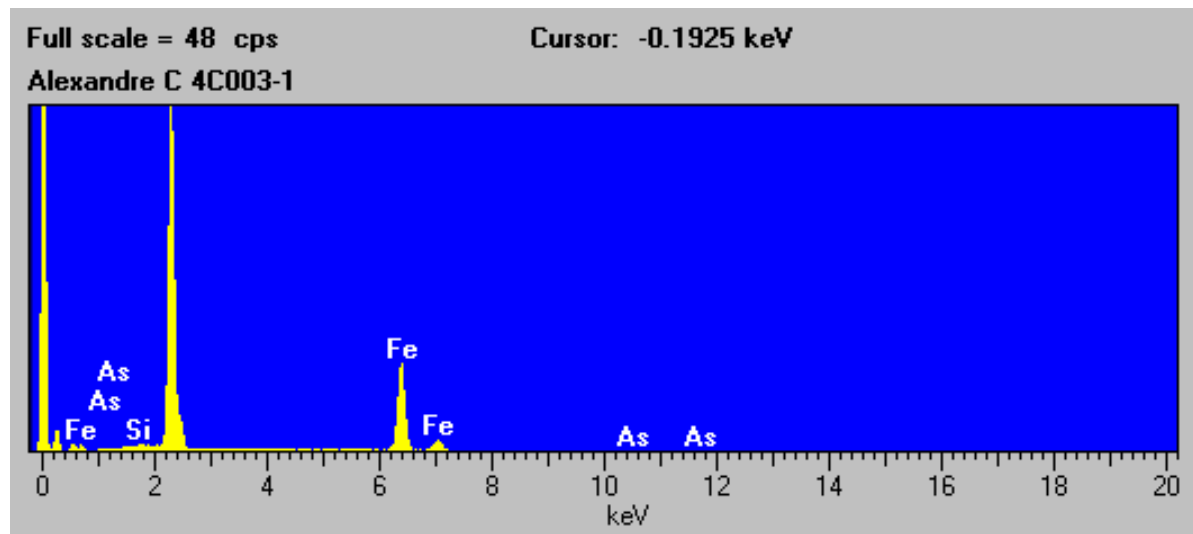

Figura 25 - Espectro EDS do ponto A da Figura 26 (cristal secundário)

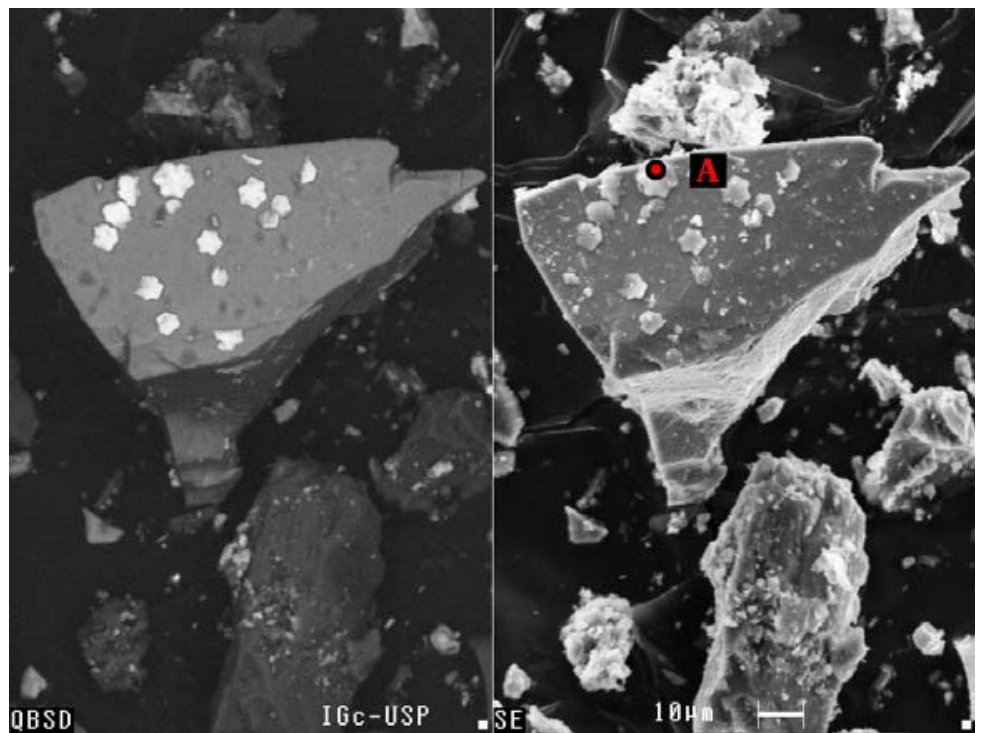

Figura 26 - Imagem com recurso split (obtida por elétrons retroespalhados à esquerda e por secundários à direita), nota-se cristais secundários precipitados sobre a superfície do fragmento carbonático

Nas análises morfológicas foram detectados minerais com formato lamelar (Figura 27) constituído por Ba e S (Figura 28). Este mineral foi extraído do horizonte mais profundo e com base no espectro apresentado pela figura 28 , provavelmente trata-se da barita $\left(\mathrm{BaSO}_{4}\right)$. 


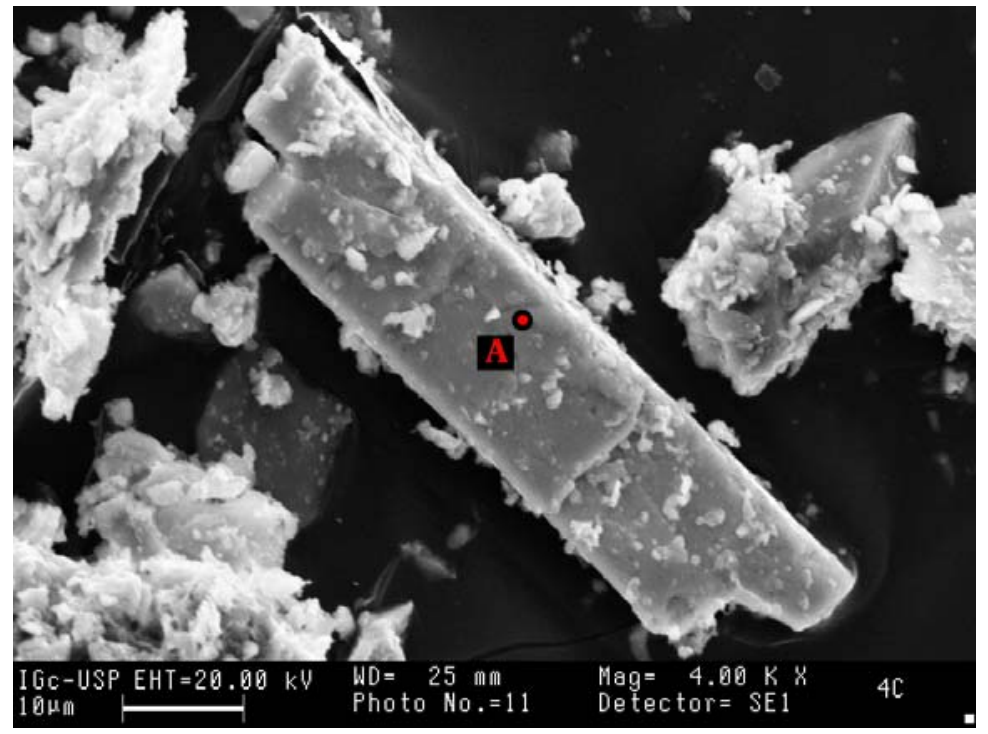

Figura 27 - Mineral lamelar encontrado na pilha de rejeito da Pumblum

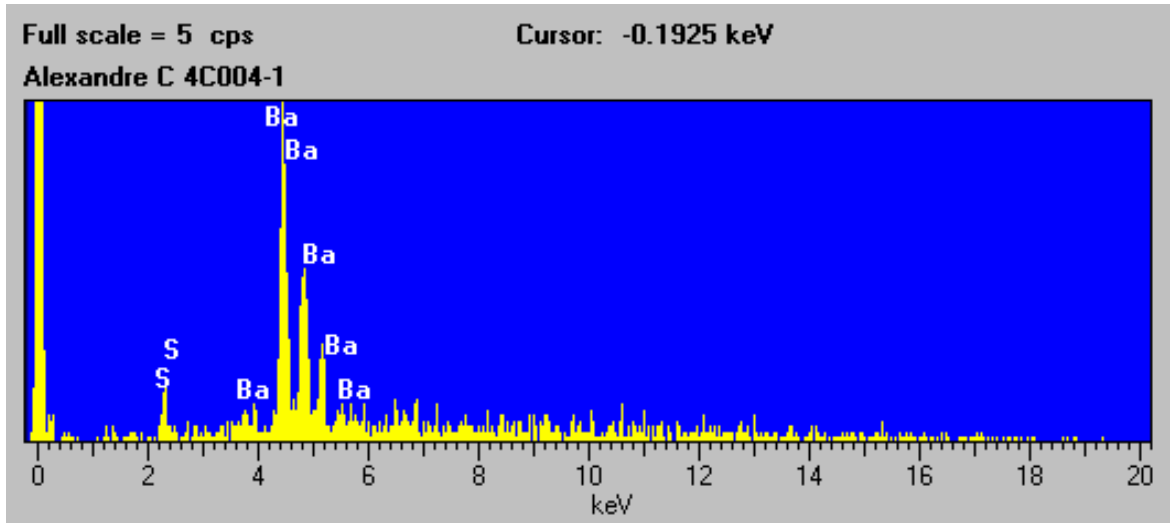

Figura 28 - Espectro EDS obtido no ponto A da figura 27

De modo geral, a matriz que compõem o rejeito da Plumbum é constituída por: $\mathrm{Pb}$, $\mathrm{Ca}, \mathrm{Ba}, \mathrm{Fe}, \mathrm{Cu}, \mathrm{Zn}$, Si e Al (Figuras 29 e 30), conforme espectros EDS obtidos em diversas amostras de diferentes profundidades.

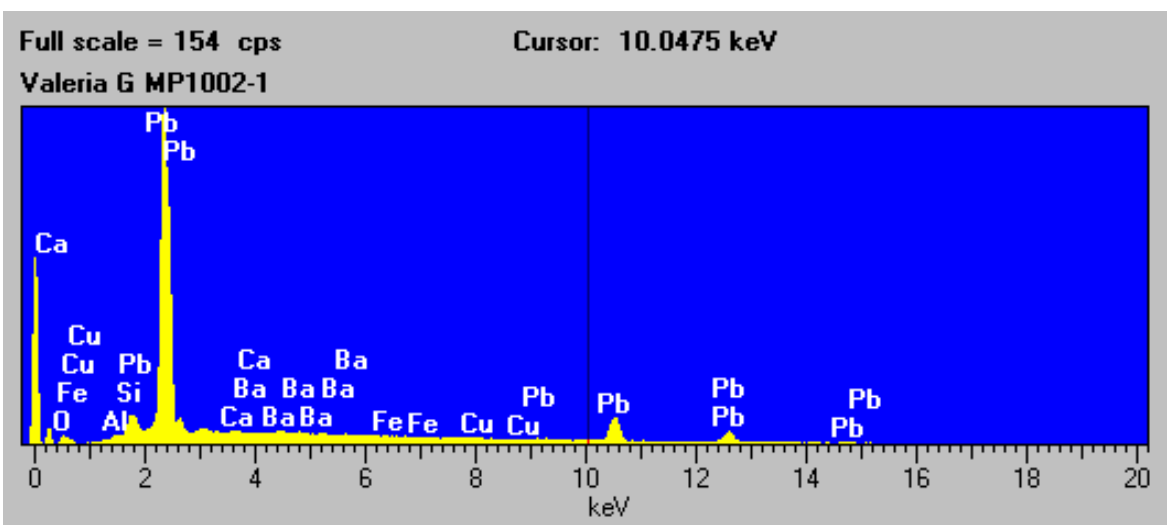

Figura 29 - EDS representativos da composição do rejeito da Plumbum 


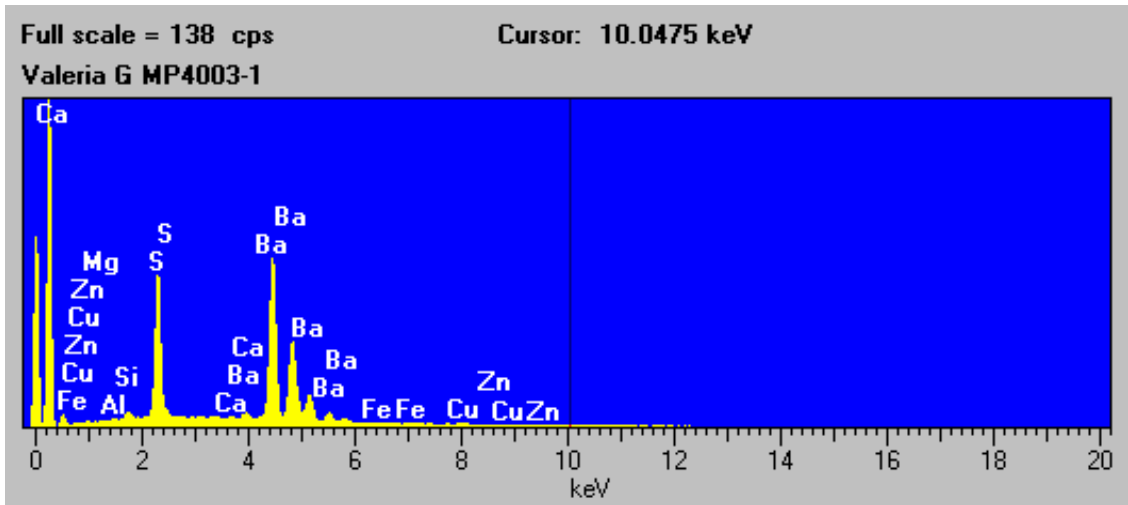

Figura 30 - EDS representativos da composição do rejeito do concentrado da Plumbum

O teste de lixiviação realizado na amostra de rejeito da Plumbum conduziu à classificação deste resíduo como pertencente a "Classe I", segundo a norma NBR 10.005 (ABNT, 1987a). Esta classificação foi baseada no teor de $\mathrm{Pb}$, que ultrapassou o limite em 41 vezes, desta forma, foi encontrado no extrato lixiviado $208 \mathrm{mg} / \mathrm{L}$ de $\mathrm{Pb}$ e o valor permitido por tal norma é de $5 \mathrm{mg} / \mathrm{L}$.

\subsubsection{Considerações sobre os resultados obtidos}

O rejeito da Plumbum é constituído pela fração areia fina a muito fina, granulometria esta promovida pelo processo de cominuição para liberação do minério no período de atividade extrativa da mina. Este material é composto, principalmente por $\mathrm{Si}, \mathrm{S}, \mathrm{Ba}$, Fe e $\mathrm{Ca}$, além dos metais $\mathrm{Zn}, \mathrm{Pb}$, Cu e $\mathrm{Cr}$.

Os altos teores de $\mathrm{Ba}$ e $\mathrm{S}$, possivelmente refletem os minérios tratados do tipo Perau beneficiados pela Plumbum. Segundo Corsi e Landim (2003), os minérios da jazida Perau, Canoas e Barrinha, todas estas consideradas mineralizações do tipo Perau, exibiram os seguintes teores máximos de Ba: $47.470 \mathrm{mg} / \mathrm{kg}, 370.000 \mathrm{mg} / \mathrm{kg}$ e $14.000 \mathrm{mg} / \mathrm{kg}$, o que possivelmente justifique a razão destes altos teores de Ba detectados no rejeito. Soma-se a isso o fato que a última mina a ser explorada foi a Mina de Canoas, possivelmente maior contribuinte para geração deste rejeito, pois os rejeitos resultantes do tratamento do minério das outras minas foram, praticamente quase em toda sua totalidade lançados nas águas do Rio Ribeira de Iguape.

A partir do extrato de $0,80 \mathrm{~m}$ foram observadas mudanças de comportamento granulométrico e químico nesta pilha de rejeitos, tal variação pode ser resultado de histórias deposicionais distintas destes resíduos ou pode ter ocorrido alterações nos processos minerais de concentração ou deposição de diferentes rejeitos oriundos do beneficiamento de minérios distintos. 
Este rejeito está sofrendo processo de alteração intempérica causado pelas condições climáticas locais, comprovado pelo aparecimento de concreções com matriz carbonática (indicação de solubilidade e precipitação de carbonatos), fixação de $\mathrm{Pb}$ e Zn nos primeiros centímetros do perfil causada pela lixiviação de outros compostos gerando concentração relativa destes elementos. A presença de cristais secundários cuja composição aparece As, representa evidência de neoformação mineral secundária deste composto, indicando possivelmente ser dissolução e recristalização da arsenopirita. Outro fato que comprova influência de processos de alteração intempérica nesta pilha de rejeitos é a constante ocorrência de minerais com feições de corrosão e dissolução, observadas em MEV.

Este rejeito, de acordo com a norma NBR 10005 é classificado como pertencente à "Classe I", como já definido anteriormente, merecendo mais atenção quanto sua interatividade com o meio ambiente. $\mathrm{O}$ pH deste rejeito foi da ordem de 7,12, observa-se neste rejeito teores elevados de $\mathrm{S}$, merecendo assim atenção maior quanto ao aspecto de interatividade com o meio ambiente.

\section{Comparação entre os resíduos de mineração}

Em uma análise simplificada, identificam-se diversas distinções entre estes dois resíduos da mineração. No concernente a granulometria global destes, o concentrado da Mina do Rocha é formado pela fração silte, enquanto que o da Plumbum é composto pelas frações areia fina a muito fina, refletindo desta forma, técnicas de concentrações do minério diferenciadas pelas distintas empresas de beneficiamento (Empresa Rocha Comércio e Exploração de Minério Ltda e Plumbum SIA Indústria Brasileira de Mineração).

Estes rejeitos diferem, também, quanto à composição química, sendo os rejeitos da Plumbum ricos em $\mathrm{Si}, \mathrm{S}, \mathrm{Ba}, \mathrm{Fe}$ e $\mathrm{Ca}$, enquanto que os do Rocha apresentam predominantemente $\mathrm{Ca}, \mathrm{Mg}$ e $\mathrm{Si}$. Tal fato é reflexo dos minérios beneficiados pelas empresas acima citadas, pois a Empresa Rocha Comércio e Exploração trabalhou só com o minério proveniente da Mina do Rocha, cujo protominério é carbonático. Por outro lado, a Empresa Plumbum, beneficiou minérios de diversas origens (praticamente de todas as minas do Vale do Ribeira e minérios importados), refletindo-se na composição química dos rejeitos, aqui investigados.

Quanto aos metais pesados, os rejeitos da Plumbum exibiram teores médios de Zn da ordem de $8.817,00 \mathrm{mg} / \mathrm{kg}$ e teores médios de $\mathrm{Pb}$ de $6.366,70 \mathrm{mg} / \mathrm{kg}$. Por outro lado os rejeitos do Rocha apresentaram teores médios de Zn de 429,09 mg/kg e teores médios de 
$\mathrm{Pb}$ de $9.435,27 \mathrm{mg} / \mathrm{kg}$. Desta forma, os rejeitos da Plumbum são mais enriquecidos em $\mathrm{Zn}$ que os do Rocha e este último é mais rico em $\mathrm{Pb}$ que os da Plumbum.

Os rejeitos da Plumbum apresentaram teores menores para os carbonatos e teores mais elevados de enxofre que os rejeitos do Rocha. Face a esta condição o pH obtido para os rejeitos da Plumbum $(7,12)$ é mais baixo em média que os do Rocha $(8,57)$. Desta forma, pode-se supor que os rejeitos da Plumbum são mais suscetíveis à ação de agentes intempéricos e conseqüentemente à lixiviação e possível disponibilidade dos metais para o meio ambiente do que os rejeito do Rocha.

As concentrações químicas de $\mathrm{Pb}$, de ambos rejeitos, obtidos nos testes de lixiviação, conduzem estes rejeitos à classificação de "perigosos" - Classe I, de acordo com os limites de concentração química fixados pela NBR 10.005. Os rejeitos da Plumbum ultrapassam em 41 vezes o valor de $\mathrm{Pb}$ fixado por tal norma, e os do Rocha ultrapassaram em 32 vezes. Isto corrobora a hipótese mencionada acima, indicando que o Rejeito da Plumbum, merece maior atenção em decorrência de suas características serem mais favoráveis à liberação dos metais pesados nele contidos. 


\subsection{Resíduos da Metalurgia}

\subsubsection{Escória}

Foram coletadas seis amostras, em torno da pilha de escória (porção superficial da pilha), de 50 em 50 m, como anteriormente apresentado no capítulo de materiais e métodos. Granulometricamente esta escória, oriunda do processo de fundição do minério, constitui-se predominantemente pela fração areia (média de 97,4\%), sendo que a fração silte compõe 2,6\% deste material. Na fração areia, ocorre o predomínio das frações areia muito grossa (média de 40,90\%) e areia grossa (40,90\%), como ilustrado no gráfico abaixo.

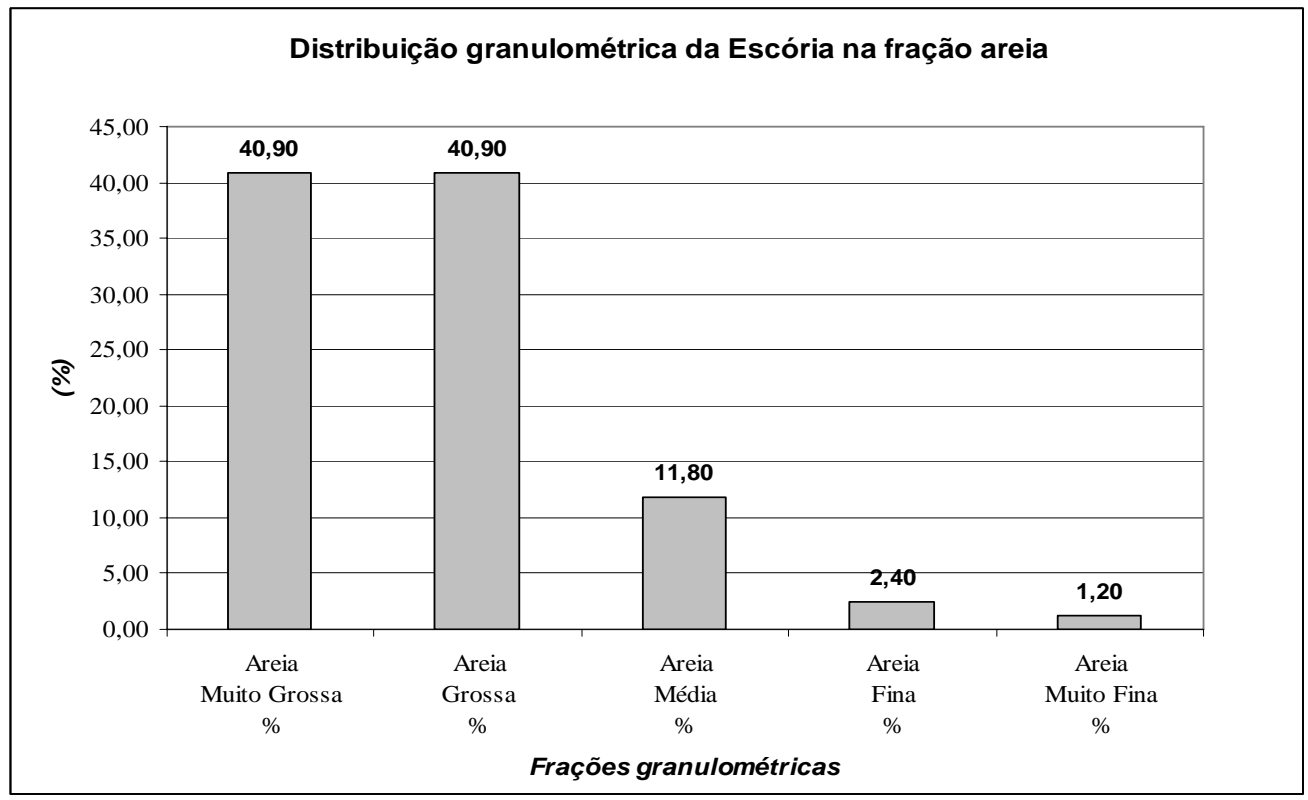

Gráfico 12 - Distribuição granulométrica da fração areia - Escória

A densidade aparente determinada para este resíduo foi de $2,015 \mathrm{~g} . \mathrm{cm}^{-3}$ enquanto que a densidade real foi de $3,877 \mathrm{~g} \cdot \mathrm{cm}^{-3}$. A grande maioria dos constituintes da escória apresentou caráter magnético. A determinação mineralógica deste material revelou vários padrões de interferência, impossibilitando a determinação precisa do conteúdo mineral desta escória.

Quanto à composição química, em \% de óxidos, verifica-se o predomínio de $\mathrm{Fe}_{2} \mathrm{O}_{3}$ (média de 26,17\% \pm 0,29), $\mathrm{SiO}_{2}$ (média de 21,71\% \pm 0,35), CaO (média de 19,68\% \pm 0,31), sendo que os outros elementos apresentam-se em concentrações inferiores a média de 5,22\% $\left(\mathrm{Al}_{2} \mathrm{O}_{3}, \mathrm{MnO}, \mathrm{MgO}, \mathrm{SO}_{3}, \mathrm{Na}_{2} \mathrm{O}, \mathrm{K}{ }_{2} \mathrm{O}, \mathrm{P}_{2} \mathrm{O}_{5}, \mathrm{TiO}_{2}\right.$ e $\left.\mathrm{BaO}\right)$. Neste rejeito também foram detectados $\mathrm{ZnO}$ (média de 12,88\% $\pm 0,08$ ) e $\mathrm{PbO}$ (média de 3,66\% $\pm 0,11$ ), conforme exposto na tabela 13. Em análises anteriores, realizadas em outro laboratório (análise 
preliminar), além destes metais pesados, também foi detectado As (média de $0,27 \%$ de óxido).

Tabela 13 - Análise química total das amostras de escória - FRX - \% de óxidos

\begin{tabular}{|c|c|c|c|c|c|c|c|c|c|c|c|c|c|c|c|c|}
\hline Amostra & $\begin{array}{c}\mathrm{SiO}_{2} \\
\%\end{array}$ & $\begin{array}{c}\mathrm{Al}_{2} \mathbf{O}_{3} \\
\%\end{array}$ & $\begin{array}{c}\mathrm{MnO} \\
\%\end{array}$ & $\begin{array}{c}\text { MgO } \\
\%\end{array}$ & $\begin{array}{c}\mathrm{CaO} \\
\%\end{array}$ & $\begin{array}{c}\mathrm{Na}_{2} \mathrm{O} \\
\%\end{array}$ & $\begin{array}{c}\mathrm{K}_{2} \mathrm{O} \\
\%\end{array}$ & $\begin{array}{c}\mathrm{TiO}_{2} \\
\%\end{array}$ & $\begin{array}{c}\mathbf{P}_{2} \mathbf{O}_{5} \\
\%\end{array}$ & $\begin{array}{c}\mathrm{Fe}_{2} \mathrm{O}_{3} \\
\%\end{array}$ & $\begin{array}{c}\mathrm{BaO} \\
\%\end{array}$ & $\begin{array}{c}\text { PbO } \\
\%\end{array}$ & $\begin{array}{c}\mathrm{SO}_{3} \\
\%\end{array}$ & $\begin{array}{c}\mathrm{ZnO} \\
\%\end{array}$ & $\begin{array}{l}\text { PF } \\
\%\end{array}$ & $\begin{array}{c}\text { Fechamento } \\
\%\end{array}$ \\
\hline Escória 1 & 21,65 & 5,26 & 0,36 & 4,15 & 19,86 & 0,79 & 0,65 & 0,53 & 0,16 & 26,03 & 0,41 & 3,63 & 1,90 & 12,92 & 1,80 & 100,10 \\
\hline Escória 2 & 21,94 & 5,24 & 0,36 & 4,07 & 19,69 & 0,78 & 0,66 & 0,53 & 0,17 & 25,82 & 0,41 & 3,83 & 1,93 & 12,76 & 1,66 & 99,85 \\
\hline Escória 3 & 22,10 & 5,22 & 0,36 & 4,05 & 19,65 & 0,76 & 0,65 & 0,54 & 0,17 & 26,61 & 0,41 & 3,67 & 1,82 & 12,89 & 1,86 & 100,76 \\
\hline Escória 4 & 21,94 & 5,23 & 0,34 & 4,09 & 19,23 & 0,78 & 0,64 & 0,52 & 0,16 & 26,43 & 0,40 & 3,73 & 1,95 & 12,95 & 1,84 & 100,23 \\
\hline Escória 5 & 21,25 & 5,25 & 0,36 & 4,11 & 20,15 & 0,77 & 0,63 & 0,54 & 0,16 & 26,08 & 0,42 & 3,58 & 1,92 & 12,95 & 1,80 & 99,97 \\
\hline Escória 6 & 21,35 & 5,10 & 0,35 & 3,97 & 19,49 & 0,77 & 0,62 & 0,53 & 0,15 & 26,04 & 0,40 & 3,54 & 1,93 & 12,83 & 1,84 & 98,91 \\
\hline Média & 21,71 & 5,22 & 0,36 & 4,07 & 19,68 & 0,78 & 0,64 & 0,53 & 0,16 & 26,17 & 0,41 & 3,66 & 1,91 & 12,88 & & \\
\hline Erro & 0,14 & 0,02 & 0,00 & 0,02 & 0,13 & 0,00 & 0,01 & 0,00 & 0,00 & 0,12 & 0,00 & 0,04 & 0,02 & 0,03 & & \\
\hline Desvio Padrão & 0,35 & $\overline{0,06}$ & 0,01 & $\overline{0,06}$ & 0,31 & $\overline{0,01}$ & 0,01 & 0,01 & $\overline{0,01}$ & 0,29 & $\overline{0,01}$ & $\overline{0,11}$ & 0,05 & $\overline{0,08}$ & & \\
\hline
\end{tabular}

Os resultados em \% de óxidos foram convertidos para $\mathrm{mg} / \mathrm{kg}$ (Tabela 14), evidenciando desta forma teores extremamente elevados de Zn (média de 118.004,33 $\mathrm{mg} / \mathrm{kg}$ ). O Pb, também foi detectado em altas concentrações, sendo sua média da ordem de $34.018,00 \mathrm{mg} / \mathrm{kg}$. O teor médio de Cu detectado foi da ordem de $2.730,33 \mathrm{mg} / \mathrm{kg}$ e o de $\mathrm{Cr}$ foi de $214,17 \mathrm{mg} / \mathrm{kg}$ (Tabela 14). Também foi determinado na escória, teor de $3.656,00$ $\mathrm{mg} / \mathrm{kg}$ de Ba (Tabela 14).

Tabela 14 - Teores de metais pesados e do Ba detectados na escória (mg/kg)

\begin{tabular}{lccccc}
\hline \multicolumn{1}{c}{ Amostra } & $\begin{array}{c}\mathbf{P b} \\
\mathbf{m g} / \mathbf{k g}\end{array}$ & $\begin{array}{c}\mathbf{Z n} \\
\mathbf{m g} / \mathbf{k g}\end{array}$ & $\begin{array}{c}\mathbf{C u} \\
\mathbf{m g} / \mathbf{k g}\end{array}$ & $\begin{array}{c}\mathbf{C r} \\
\mathbf{m g} / \mathbf{k g}\end{array}$ & $\begin{array}{c}\mathbf{B a} \\
\mathbf{~ m g} / \mathbf{k g}\end{array}$ \\
\hline \hline Escória 1 & $33.716,00$ & $118.330,00$ & $2.973,00$ & 231,00 & $3.652,00$ \\
Escória 2 & $35.540,00$ & $116.909,00$ & $2.832,00$ & 215,00 & $3.686,00$ \\
Escória 3 & $34.024,00$ & $118.072,00$ & $2.794,00$ & 195,00 & $3.658,00$ \\
Escória 4 & $34.672,00$ & $118.592,00$ & $2.710,00$ & 217,00 & $3.610,00$ \\
Escória 5 & $33.272,00$ & $118.647,00$ & $2.548,00$ & 218,00 & $3.735,00$ \\
Escória 6 & $32.884,00$ & $117.476,00$ & $2.525,00$ & 209,00 & $3.595,00$ \\
\hline \hline \multicolumn{1}{c}{ LD } & $\mathbf{5 , 0 0}$ & $\mathbf{1 , 0 0}$ & $\mathbf{2 , 0 0}$ & $\mathbf{2 , 0 0}$ & $\mathbf{1 7 , 0 0}$ \\
\hline \hline Média & $\mathbf{3 4 . 0 1 8 , 0 0}$ & $\mathbf{1 1 8 . 0 0 4 , 3 3}$ & $\mathbf{2 . 7 3 0 , 3 3}$ & $\mathbf{2 1 4 , 1 7}$ & $\mathbf{3 . 6 5 6 , 0 0}$ \\
\hline \hline
\end{tabular}

LD: Limite de Detecção do Aparelho

Como exibe a tabela acima as concentrações de $\mathrm{Zn}$ e Pb são muito elevadas, sendo que o valor de $\mathrm{Pb}$ ultrapassa o valor de referência encontrado na norma ABNT-NBR (10.005) para resíduos sólidos em 34 vezes (valor permitido de $1.000 \mathrm{mg} / \mathrm{kg}$ ). Por outro lado à concentração de $\mathrm{Zn}$ é de 118.004,33 mg/kg. Com base no conteúdo de $\mathrm{Pb}$ observado neste resíduo, este pode ser classificado, em um primeiro momento, como pertencente à "Classe I", segundo a norma acima mencionada. 
Como complemento das análises químicas e caracterização física, a escória foi analisada em MEV/EDS (análise química pontual qualitativa). Em MEV, obteve-se a imagem da escória (figura abaixo), com detector de elétrons retro-espalhados.

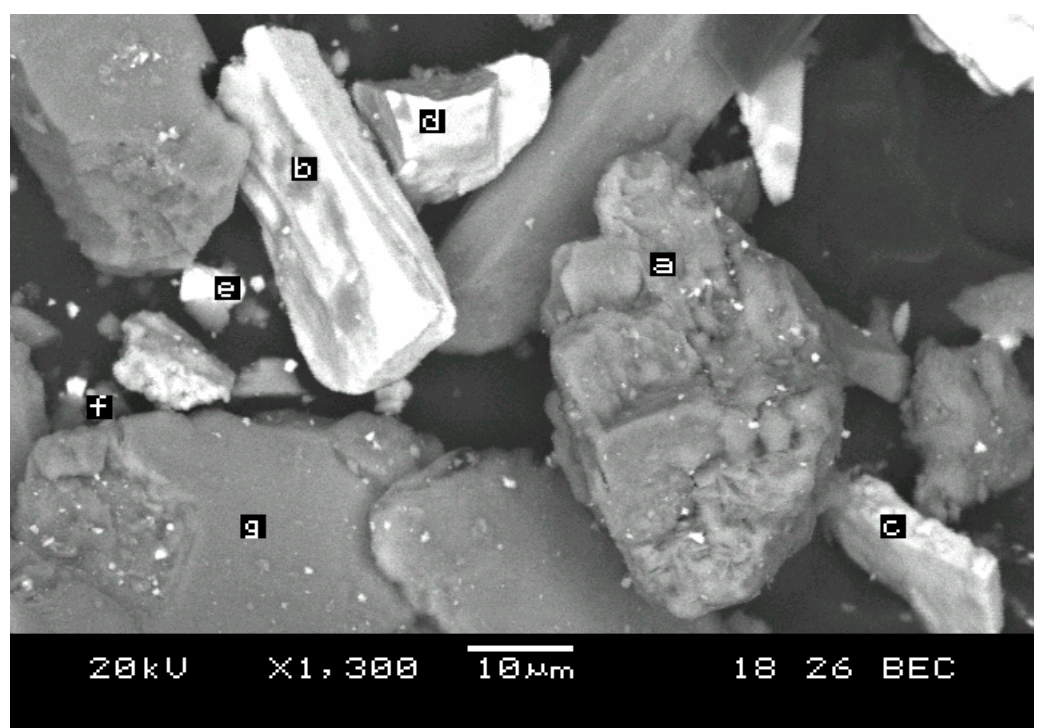

Figura 31 - Imagem com elétrons retro-espalhados em MEV da escória

$\mathrm{Na}$ imagem da figura 31 foram escolhidos alguns pontos para análises químicas pontuais qualitativas $(\mathbf{a}, \mathbf{b}, \mathbf{c}, \mathbf{d}, \mathbf{e}, \mathbf{f}$ e $\mathbf{g})$. Os espectros EDSs obtidos nestes pontos exibiram, principalmente a presença de Zn, Fe, Si e Ca (Figura 32).

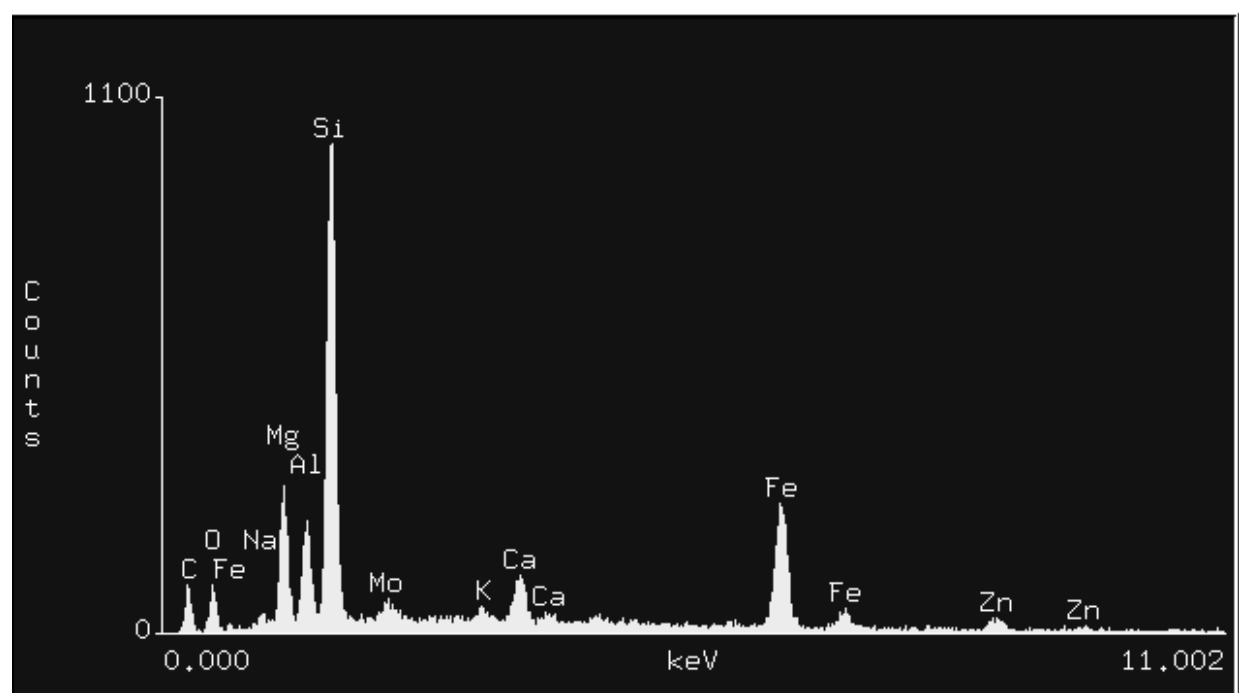

Figura 32 - Espectro EDS representativos da composição da escória

O teste de lixiviação realizado na escória provou ser este resíduo resistente ao ataque ácido, pois mesmo apresentando concentrações elevadas de $\mathrm{Pb}$, este não foi liberado. O teor de $\mathrm{Pb}$ obtido no extrato lixiviado foi de $0,46 \mathrm{mg} / \mathrm{kg}$, ou seja, encontra-se bem abaixo do teor fixado pela norma NBR 10.005 (5,0 mg/kg). 


\subsubsection{Considerações sobre os resultados obtidos}

A partir destas caracterizações, observa-se que a escória é um material com granulometria grossa, magnético, com alta densidade e rico em Fe, Si e Ca. Este material exibe teores elevados de Zn (média de 118.004,33 mg/kg) e Pb (34.018,00 mg/kg).

A alta densidade da escória é reflexo dos altos teores de $\mathrm{Fe}, \mathrm{Pb}$ e $\mathrm{Zn}$ contidos em sua composição. Conforme Anjos (1998), a escória produzida pela empresa Plumbum localizada no município de Santo Amaro da Purificação (Recôncavo Baiano), sofreu processos de sinterização por ustulação da galena, mais redução do sinter, resultando em escória com a seguinte composição química: $\mathrm{SiO}_{2}$ (20 a 25\%); FeO (28 a 35\%); $\mathrm{CaO}$ (15 a 20\%): PbO (1 a 3\%); ZnO (8 a 12\%) e $\mathrm{SO}_{3}$ (1 a 3\%). Estes teores reportados por Anjos (1998) exibem similaridade com os valores obtidos neste estudo: $\mathrm{SiO}_{2}(21,71 \%) ; \mathrm{FeO}$ (26,17\%); $\mathrm{CaO}$ (19,68\%): $\mathrm{PbO}(3,66 \%) ; \mathrm{ZnO}(12,88 \%)$ e $\mathrm{SO}_{3}(1,91 \%)$, indicando que esta composição e proporção resultam de processo metalúrgico similar ao empregado na fundição do minério concentrado de $\mathrm{Pb}$ da Plumbum de Santo Amaro da Purificação.

Os resultados obtidos para as seis amostras de escória mostraram que não existe diferença composicional ao longo da pilha, pois os resultados de concentração química para as diversas amostras exibiram forte aproximação numérica.

Os valores referentes ao $\mathrm{pH}$ inicialmente obtidos nos teste de lixiviação foram da ordem de 7,51 . Tal fato pode relacionar-se com a presença de $\mathrm{CaO}(19,68 \%)$ em fase livre (como composto solúvel), o que possivelmente esta promovendo a neutralização do sistema e elevando o valor numérico do $\mathrm{pH}$.

\subsection{SEDIMENTOS}

São aqui apresentados os resultados utilizados na caracterização dos diferentes sedimentos, obtidos em análises granulométricas, mineralógicas, químicas e determinações de matéria orgânica. Tais resultados serão exibidos separadamente para cada um dos sedimentos, obedecendo à ordem exposta a seguir: Sedimentos Depositados em Banco de Areia, Sedimentos Ativos de Corrente, Sedimentos em Suspensão e Sedimentos Estuarinos.

Nesta caracterização optou-se por explanar, com maior detalhe, alguns elementos químicos ( $\mathrm{Ca}, \mathrm{Mg}, \mathrm{Fe}, \mathrm{Pb}, \mathrm{Zn}, \mathrm{Ba}, \mathrm{Cr}$ e $\mathrm{Cu}$ ), para os diversos tipos de sedimentos, facilitando assim a visualização das diferentes características de cada um destes materiais. 


\subsubsection{Sedimentos depositados em bancos de areia}

Para este tipo de coleta de sedimento foi empregada amostragem em perfis de sondagens, com aproximadamente $0,60 \mathrm{~m}$ de profundidade (com exceção do ponto IE04 que atingiu 3,0 m), em bancos de areia de três porções distintas do Rio Ribeira de Iguape, segmento Iporanga-Eldorado (IE), segmento Eldorado-Sete Barras (ESB) e confluência com o Rio Juquiá (JU). Os resultados mineralógicos indicaram que os sedimentos amostrados nestes três segmentos são compostos, principalmente por quartzo, micas e fragmentos de rochas xistosas.

O teor médio de matéria orgânica detectado neste material foi de $0,35 \%$, sendo que se observaram variações neste teor conforme o segmento do rio onde foram realizadas as coletas. Na porção do rio entre os municípios de Iporanga e Eldorado (segmento IE) o teor médio de matéria orgânica foi de 0,50\%, entre os municípios de Eldorado e Sete Barras (segmento ESB) este teor foi de $0,28 \%$ e na porção correspondente à confluência do Rio Ribeira com o Rio Juquiá este teor foi de 0,40\%.

As determinações granulométricas foram executadas nos primeiros 20 centímetros dos perfis de sondagem coletados nos três segmentos do rio. Neste estudo, notou-se que este sedimento é composto em média por 92,56\% da fração areia, 6,94\% da fração silte e 0,61\% da fração argila, apresentando variações de um ponto para outro. De modo geral, os pontos localizados em Ivaporanduva (próximo de Eldorado - IE06) e em Juquiá (JU) são mais enriquecidos na fração areia e conseqüentemente mais empobrecidos em silte e argila, por outro lado o ponto de amostragem próximo do município de Iporanga (IE01) apresentou maiores teores de silte e argila se comparado com as outras amostras (Gráfico 13).

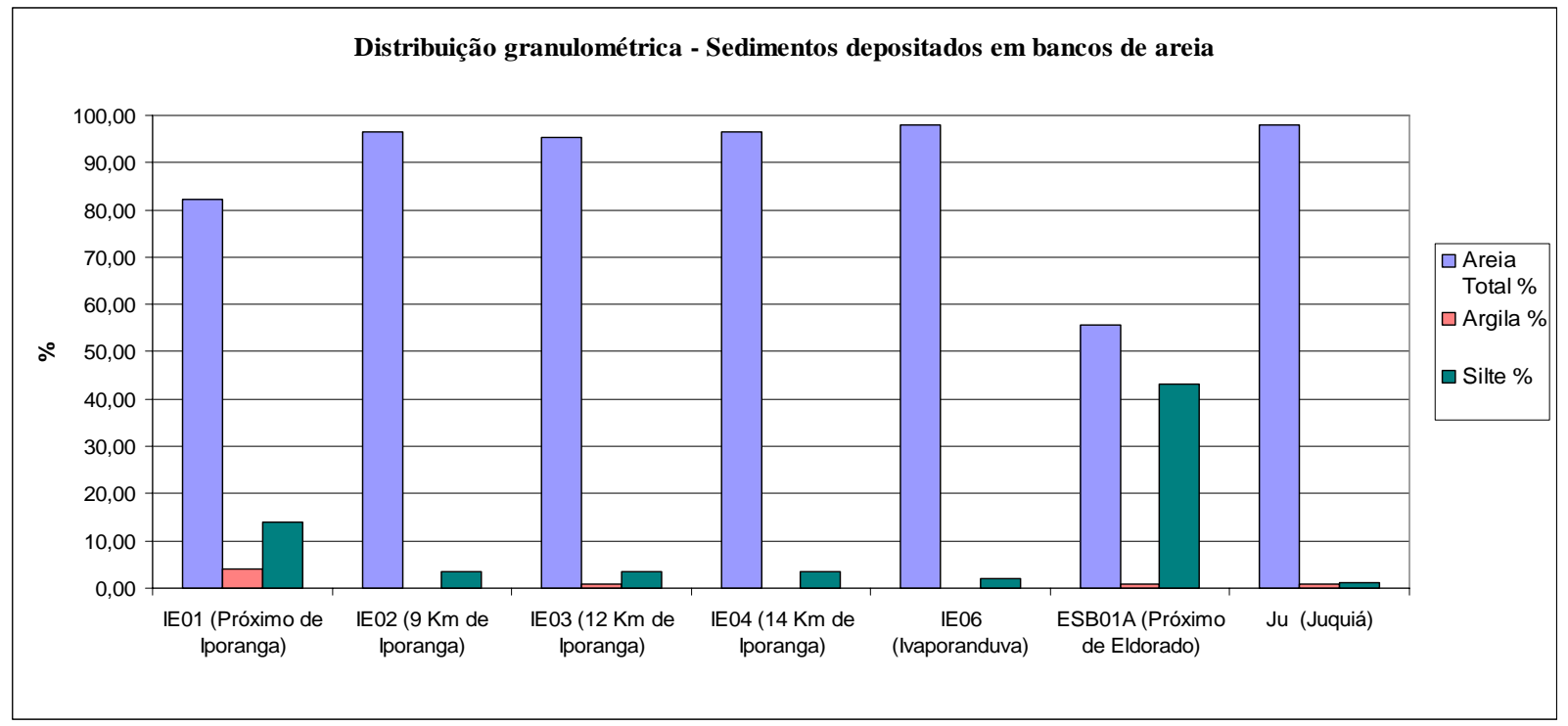

Gráfico 13 - Distribuição granulométrica das amostras de sedimentos depositados em bancos de areia 
Esta distribuição granulométrica, principalmente dentro da fração areia, exibe variações conforme o ponto de amostragem, refletindo assim a energia do ambiente de deposição, como pode ser observado no gráfico 14. Neste gráfico, verifica-se que as amostras IE02 e IE03 apresentam a mesma tendência com relação à distribuição granulométrica, isto é, teores mais elevados para as frações areia média, fina e grossa. Por outro lado às amostras IE04 e JU são mais enriquecidas nas frações areia média, grossa e fina. A caracterização granulométrica da amostra IE06 comprovou ser este material composto principalmente pelas frações areia grossa, média e muito grossa, conforme exibe este mesmo gráfico. As amostras IE01 e ESB01A mostraram maior heterogeneidade com relação à distribuição granulométrica, ressaltando que a amostra IE01 apresenta granulometria mais fina que as outras, variação esta composta por: areia muito fina, fina e média, respectivamente.

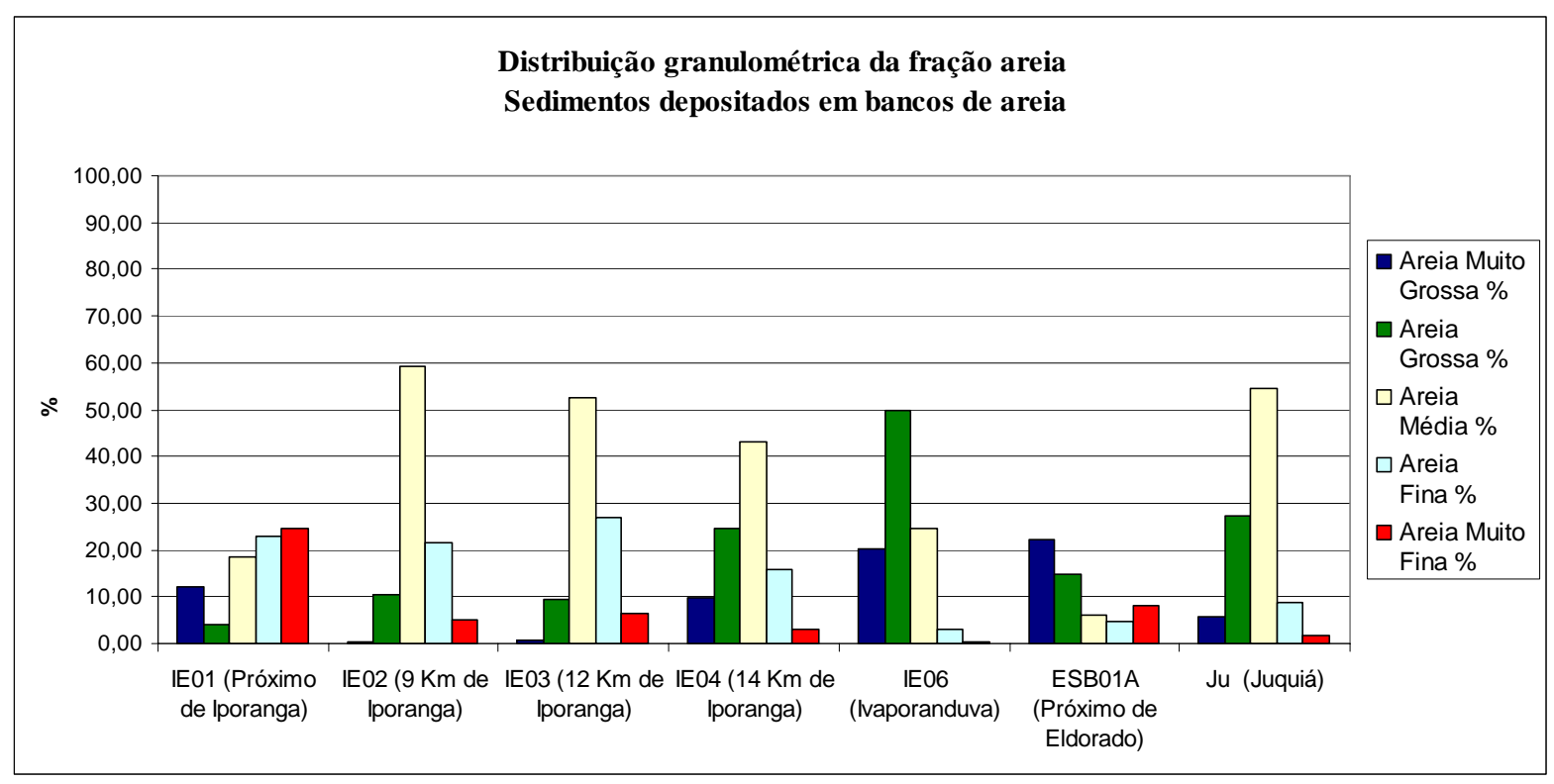

Gráfico 14 - Distribuição granulométrica da fração areia nos sedimentos em bancos de areia

Resumidamente, as amostras localizadas nas proximidades de Iporanga (IE01, IE02 e IE03) são compostas por frações granulométricas mais finas que as amostras coletadas nas proximidades de Eldorado, Sete Barras e Juquiá (IE04, IE06, ESB01A e JU), como indicado no gráfico 14.

As análises químicas totais foram obtidas em todos os sedimentos amostrados e exibiram a seguinte composição média: $80,96 \%$ de $\mathrm{SiO}_{2} ; 8,13 \%$ de $\mathrm{Al}_{2} \mathrm{O}_{3} ; 3,27 \%$ de $\mathrm{K}_{2} \mathrm{O}$; $3,02 \%$ de $\mathrm{Fe}_{2} \mathrm{O}_{3}$ e $1,35 \%$ de $\mathrm{Na}_{2} \mathrm{O}$, além de outros elementos, inclusive os metais pesados, com valores inferiores a $1 \%$ (anexo 1 ). 
Os teores de $\mathrm{ZnO}$ e $\mathrm{PbO}$ detectados em algumas amostras foram equivalentes ao limite de detecção do aparelho empregado na análise $(0,01 \%)$, desta forma, devido à confiabilidade dos dados considerou-se os valores acima deste limite de detecção $(0,02 \%)$, embora para melhor visualização, nos gráficos de $\mathrm{Pb}$ e $\mathrm{Zn}$, que serão exibidos mais adiante, preferiu-se colocar estes valores convertidos para $\mathrm{mg} / \mathrm{kg}$, pois quando convertidos, estes estão acima dos valores de referência PEL/TEL do CCME (1999) para sedimento. Dos metais pesados investigados o $\mathrm{Cr}$ foi o que apresentou maior concentração, a média de $\mathrm{Cr}_{2} \mathrm{O}_{3}$ foi de $0,07 \%$. Ainda conforme esta análise química observou-se a ausência de $\mathrm{Cu}$ para todas as amostras nestes sedimentos.

No intuito de se identificar possibilidade de correlação entre os elementos químicos analisados nos sedimentos depositados em bancos de areia, elaborou-se a matriz de correlação de Pearson (Tabela 15). Esta matriz exibe forte correlação positiva entre: fração areia-K; fração areia-Zn; fração argila-P; Mg-Ca; Mg-Ti; Mg-Pb; Mg-Fe; Ca-Ti; Ca-Fe; Ca$\mathbf{P b}$; Ti-Fe; P-S; S-Fe; Fe-Pb; Zn-Pb, para isto foram considerados valores acima de 0,75. Dentre estas correlações, as do Ca-Mg; $\mathrm{Mg}-\mathrm{Ti}$ e $\mathrm{Ca}-\mathrm{Ti}$, foram consideradas as mais elevadas.

Tabela 15 - Matriz de Correlação de Pearson para as frações granulométricas e os elementos detectados nos sedimentos depositados em bancos de areia

\begin{tabular}{|c|c|c|c|c|c|c|c|c|c|c|c|c|c|c|c|c|}
\hline & Areia & Silte & Argila & $\mathrm{SiO}_{2}$ & $\mathrm{Al}_{2} \mathrm{O}_{3}$ & $\mathrm{MnO}$ & $\mathrm{MgO}$ & $\mathrm{CaO}$ & $\mathrm{Na}_{2} \mathrm{O}$ & $\mathrm{K}_{2} \mathrm{O}$ & $\mathrm{TiO}_{2}$ & $\mathrm{P}_{2} \mathrm{O}_{5}$ & $\mathrm{SO}_{3}$ & $\mathrm{Fe}_{2} \mathrm{O}_{3}$ & $\mathrm{Cr}_{2} \mathrm{O}_{3}$ & $\mathrm{BaO}$ \\
\hline Areia & 1,00 & & & & & & & & & & & & & & & \\
\hline Silte & $-1,00$ & 1,00 & & & & & & & & & & & & & & \\
\hline Argila & $-0,34$ & 0,25 & 1,00 & & & & & & & & & & & & & \\
\hline $\mathrm{SiO}_{2}$ & $-0,30$ & 0,36 & $-0,62$ & 1,00 & & & & & & & & & & & & \\
\hline $\mathrm{Al}_{2} \mathrm{O}_{3}$ & 0,32 & $-0,39$ & 0,63 & $-0,99$ & 1,00 & & & & & & & & & & & \\
\hline $\mathrm{MnO}$ & 0,34 & $-0,39$ & 0,39 & $-0,94$ & 0,93 & 1,00 & & & & & & & & & & \\
\hline $\mathrm{MgO}$ & 0,06 & $-0,10$ & 0,43 & $-0,85$ & 0,78 & 0,86 & 1,00 & & & & & & & & & \\
\hline $\mathrm{CaO}$ & 0,22 & $-0,26$ & 0,34 & $-0,87$ & 0,80 & 0,89 & 0,99 & 1,00 & & & & & & & & \\
\hline $\mathrm{Na}_{2} \mathrm{O}$ & $-0,15$ & 0,16 & $-0,13$ & $-0,25$ & 0,14 & 0,39 & 0,70 & 0,68 & 1,00 & & & & & & & \\
\hline $\mathrm{K}_{2} \mathrm{O}$ & 0,93 & $-0,96$ & $-0,02$ & $-0,55$ & 0,59 & 0,53 & 0,24 & 0,38 & $-0,17$ & 1,00 & & & & & & \\
\hline $\mathrm{TiO}_{2}$ & 0,20 & $-0,24$ & 0,37 & $-0,86$ & 0,78 & 0,87 & 0,98 & 0,99 & 0,66 & 0,35 & 1,00 & & & & & \\
\hline $\mathrm{P}_{2} \mathrm{O}_{5}$ & 0,16 & $-0,24$ & 0,78 & $-0,77$ & 0,84 & 0,65 & 0,37 & 0,36 & $-0,36$ & 0,45 & 0,36 & 1,00 & & & & \\
\hline $\mathrm{SO}_{3}$ & 0,15 & $-0,22$ & 0,68 & $-0,92$ & 0,94 & 0,85 & 0,68 & 0,67 & $-0,01$ & 0,42 & 0,67 & 0,89 & 1,00 & & & \\
\hline $\mathrm{Fe}_{2} \mathrm{O}_{3}$ & 0,40 & $-0,46$ & 0,50 & $-0,96$ & 0,91 & 0,89 & 0,88 & 0,92 & 0,37 & 0,59 & 0,93 & 0,60 & 0,79 & 1,00 & & \\
\hline $\mathrm{Cr}_{2} \mathrm{O}_{3}$ & 0,36 & $-0,34$ & $-0,31$ & 0,18 & $-0,05$ & 0,01 & $-0,46$ & $-0,40$ & $-0,46$ & 0,30 & $-0,45$ & 0,19 & $-0,05$ & $-0,33$ & 1,00 & \\
\hline $\mathrm{BaO}$ & 0,05 & $-0,01$ & $-0,53$ & 0,30 & $-0,42$ & $-0,26$ & 0,12 & 0,14 & 0,64 & $-0,11$ & 0,13 & $-0,80$ & $-0,60$ & $-0,07$ & $-0,50$ & 1,00 \\
\hline $\mathrm{ZnO}$ & 0,75 & $-0,74$ & $-0,34$ & $-0,33$ & 0,29 & 0,33 & 0,30 & 0,41 & 0,16 & 0,73 & 0,37 & $-0,03$ & 0,17 & 0,44 & $-0,09$ & 0,38 \\
\hline $\mathrm{PbO}$ & 0,39 & $-0,41$ & 0,13 & $-0,67$ & 0,57 & 0,60 & 0,78 & 0,82 & 0,54 & 0,50 & 0,81 & 0,13 & 0,44 & 0,79 & $-0,56$ & 0,43 \\
\hline
\end{tabular}

A partir dos resultados obtidos na matriz de correlação, preferiu-se discutir o comportamento das concentrações químicas dos elementos mais importantes neste estudo em grupos, conforme correlações positivas entre estes elementos. Desta forma vão ser abordados: Ca-Mg-Fe e Pb-Zn. O Cr-Ba, apesar de terem correlação negativa, serão apresentados conjuntamente, uma vez que estes são elementos diferenciadores na caracterização deste material. 


\section{$\underline{\mathrm{Ca}, \mathrm{Mg} \mathrm{e} \mathrm{Fe}}$}

Os teores médios detectados nestes sedimentos para estes elementos foram respectivamente: $\mathrm{CaO}$ de $0,81 \%, \mathrm{MgO}$ de $0,68 \%$ e $\mathrm{Fe}_{2} \mathrm{O}_{3}$ de $3,02 \%$. Estes teores, nos perfis de sondagem concentram-se na porção superficial (de 0-0,20 m) como pode ser observado no anexo 1, com exceção da amostra IE08NE08 que apresentou teores mais elevados para estes três elementos no patamar de 0,20-0,40 m. O teor mais elevado de $\mathrm{CaO}$ foi obtido para a amostra IE08NE08 $(0,20-0,40 \mathrm{~m})$, sendo que este ultrapassou o teor médio em aproximadamente quatro vezes.

As coletas realizadas de 50 em $50 \mathrm{~m}$ em um mesmo banco de areia mostraram a inexistência de variações significativas para estes três elementos em um mesmo horizonte, variação lateral.

Para verificação da tendência de concentração química destes elementos ao longo do Rio Ribeira de Iguape foram empregados os resultados obtidos apenas nas amostras do topo, equivalente aos primeiros 20 centímetros (Gráfico 15). Neste gráfico, nota-se similaridade das curvas de concentração do $\mathrm{Ca}, \mathrm{Mg}$ e $\mathrm{Fe}$, com algumas exceções, confirmando assim os resultados obtidos na matriz de correlação de Pearson. De modo geral, o Ca e Fe exibem a mesma tendência química de concentração para todos os pontos de amostragem, enquanto o $\mathrm{Mg}$ apresentou tendência distinta destes dois elementos nos pontos IE08 e IE09 (Gráfico 15).

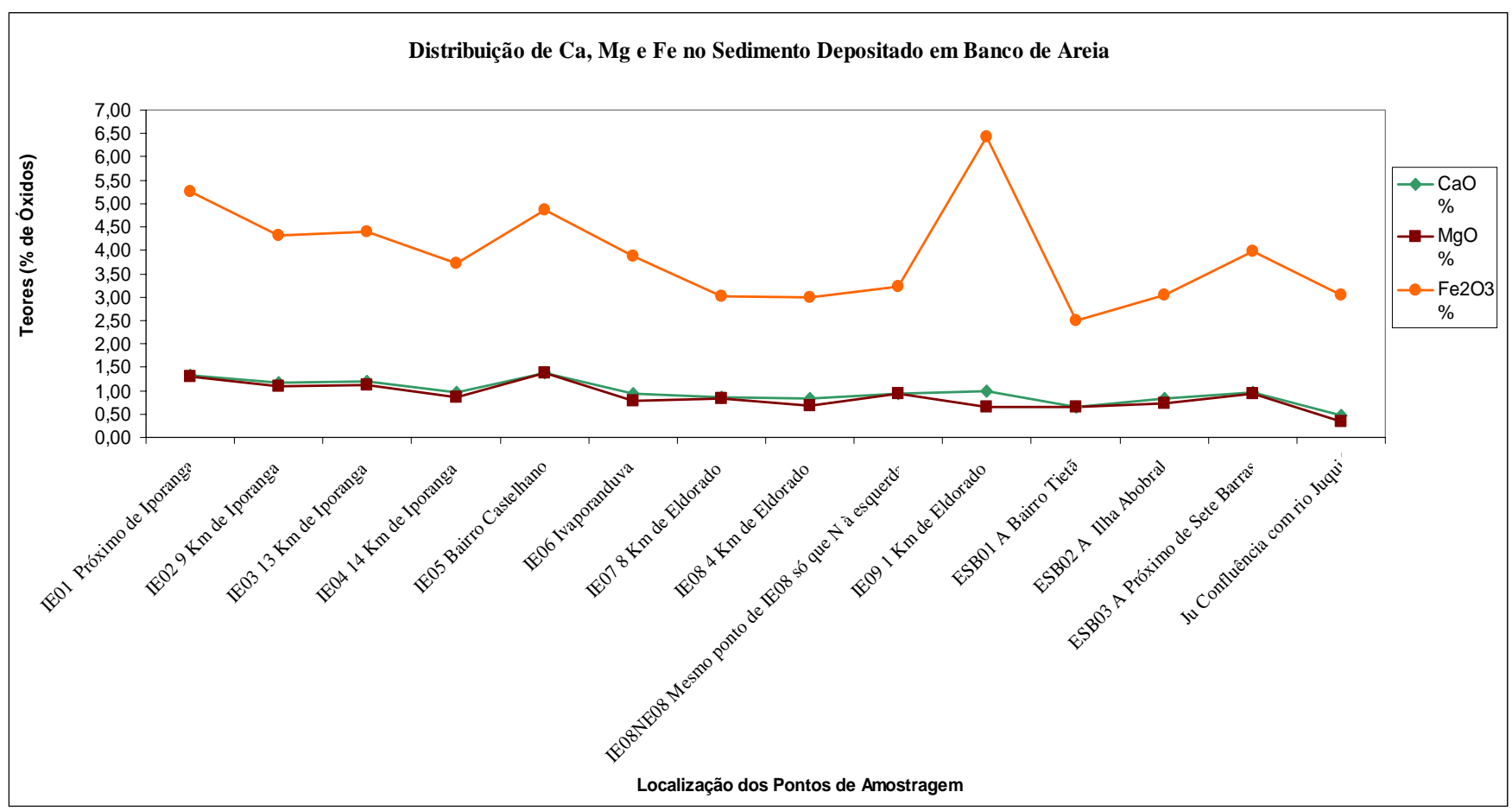

Gráfico 15 - Distribuição de Ca, Mg e Fe nas amostras de 0,20 m coletadas em bancos de areia ao longo do Rio Ribeira 
Os teores de $\mathrm{Ca}$, Mg e Fe tendem a diminuir em direção a foz do Rio Ribeira de Iguape, sentido Sete Barras - Juquiá, como visualizado no gráfico 15. Nas amostras IE05 (Bairro Castelhano), ESB03A (próximo de Sete Barras) e IE01 (próximo de Iporanga) foram encontrados os maiores teores para estes três elementos, possivelmente indicando anomalias geogênicas. Os teores mais baixos de $\mathrm{Ca}$, $\mathrm{Mg}$ e Fe foram detectados para as amostras de sedimento do Rio Juquiá (JU) e as do Bairro Tietã (ESB01A).

$\underline{\mathrm{Pb} \text { e } \mathrm{Zn}}$

O teor médio de $\mathrm{Pb}$ detectado nos sedimentos depositados em bancos de areia foi de $135,27 \mathrm{mg} / \mathrm{kg}$ e o de $\mathrm{Zn}$ da ordem de 112,65 mg/kg. Como já comentado só foram considerados valores acima do limite de detecção do aparelho. Estes teores médios estão acima dos valores de background regional, definidos por CPRN (1978) para o Zn (47 mg/kg) e para o $\mathrm{Pb}(16 \mathrm{mg} / \mathrm{kg})$.

Os teores de $\mathrm{Pb}$ e $\mathrm{Zn}$ são mais elevados nas amostras de topo, com exceção da amostra IE03 e IE08NE08. Na amostragem realizada a $9 \mathrm{~km}$ de Iporanga (IE02) constatouse que os teores de $\mathrm{Pb}$ e $\mathrm{Zn}$ mantêm-se elevados com a profundidade, média de 186,00 $\mathrm{mg} / \mathrm{kg}$ de $\mathrm{Pb}$ e média de $160,00 \mathrm{mg} / \mathrm{kg}$ de $\mathrm{Zn}$.

Quanto à variação lateral, verificou-se mudança no teor de $\mathrm{Pb}$ e $\mathrm{Zn}$ para a amostra ESB02B, que é mais enriquecida que a amostra localizada $50 \mathrm{~m}$ à esquerda desta (ESB02A), apontando a necessidade deste tipo de coleta em alguns bancos de areia.

Para visualização da distribuição de $\mathrm{Pb}$ e $\mathrm{Zn}$ ao longo do Rio Ribeira de Iguape foram utilizadas as amostras superficiais do perfil de sondagem (0-0,20 m). O gráfico 16 exibe esta distribuição, mostrando tendência de decréscimo destes metais pesados em direção à foz do rio, em Sete Barras e Juquiá (amostras ESB01A, ESB01C e JU) estes teores não foram detectados pelo aparelho (FRX). Nos pontos localizados a $9 \mathrm{~km}$ (IE02) e $14 \mathrm{~km}$ de Iporanga (IE04) foram revelados teores mais altos de Pb e Zn (Gráfico 16). 


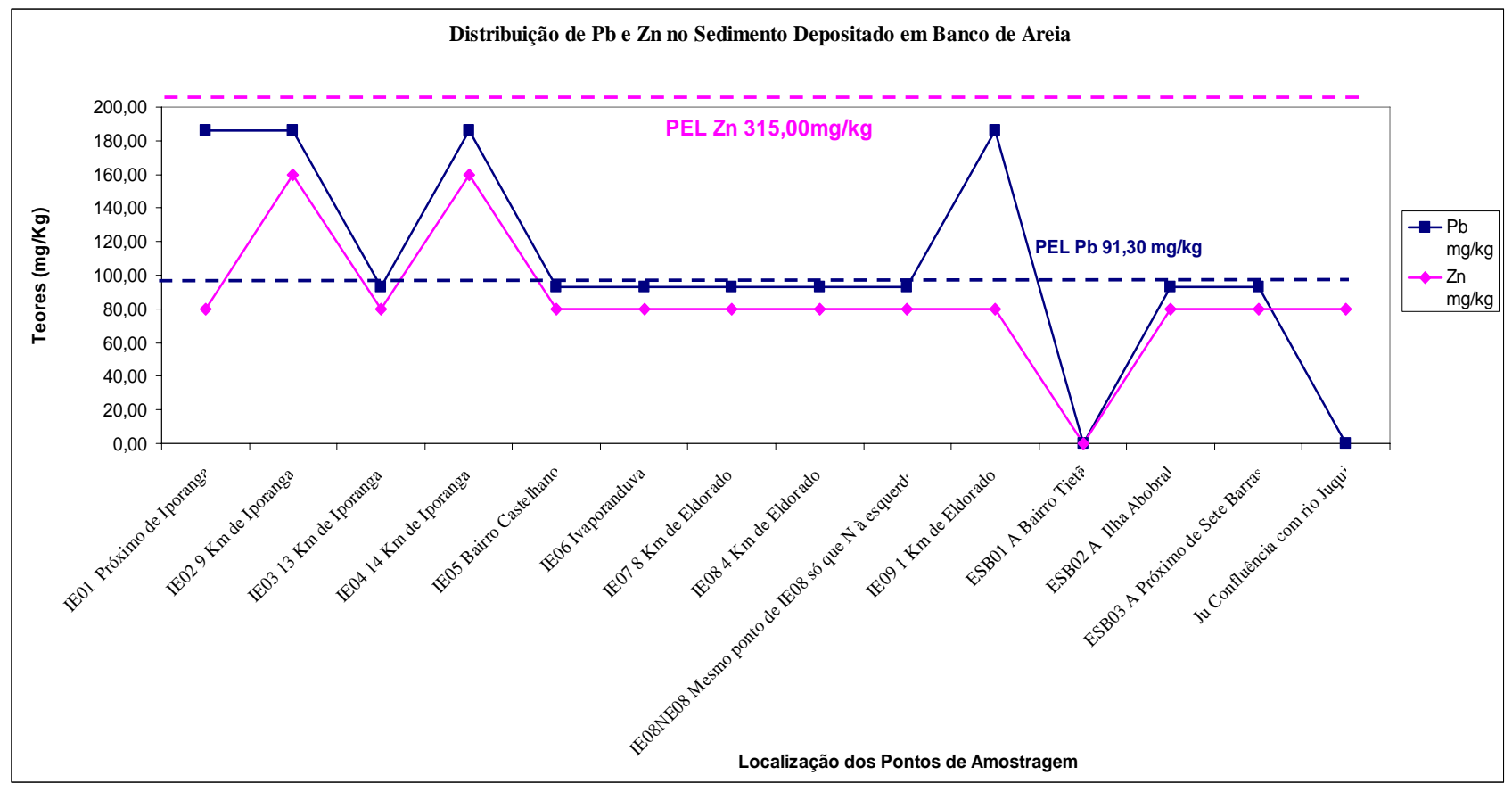

Gráfico 16 - Distribuição de Pb e Zn nas amostras de 0,20 m coletadas em bancos de areia ao longo do Rio Ribeira

$\mathrm{Na}$ maioria dos sedimentos o $\mathrm{Pb}$ e $\mathrm{Zn}$ apresentam mesma tendência de concentração química, como anteriormente comentado para os resultados da matriz de correlação de Pearson. Estes metais concentram-se nas proximidades de Iporanga (IE02 e IE 04) e desaparecem nas amostras de sedimento coletadas em Sete Barras (Bairro Tieta) e em Juquiá.

Como indicativo da possível contaminação destes metais pesados foi empregado 0 valor de referência PEL/TEL do CCME (1999). O teor de Pb obtido nas amostras IE01, IE02, IE04 e IE09 ultrapassaram o valor de referência PEL em 2 vezes, indicando que nestes pontos devem ser executadas análises mais detalhadas para verificar possível disponibilidade deste metal para o meio ambiente (Gráfico 16). Para as outras amostras os teores detectados ultrapassaram o valor de referência TEL, o que significa um valor de alerta, ou seja, necessidade de se manter constante monitoramento deste material.

Em todos os sedimentos analisados, o teor de Zn não ultrapassou o valor de referência PEL, como exibe o gráfico 16. Este metal só excedeu o valor de referência TEL para as amostras IE02, IE04 e ESBO2B significando alerta quanto a este material e apontando para um monitoramento mais detalhado deste elemento nesta variedade de sedimento.

Cabe ressaltar que estes valores de referência são apenas um indicativo, necessitando assim estudos complementares para verificação do grau de toxicidade destes metais neste ambiente. 


\section{$\underline{\mathrm{Ba} \text { e } \mathrm{Cr}}$}

O teor médio de $\mathrm{BaO}$ encontrado nos sedimentos em bancos de areia foi de $0,12 \%$ e o de $\mathrm{Cr}_{2} \mathrm{O}_{3}$ foi de $0,07 \%$. Estes dois elementos apresentam relação inversamente proporcional no que diz respeito as suas concentrações obtidas nos pontos amostrados, refletindo esta tendência na curva de concentração química do gráfico 17.

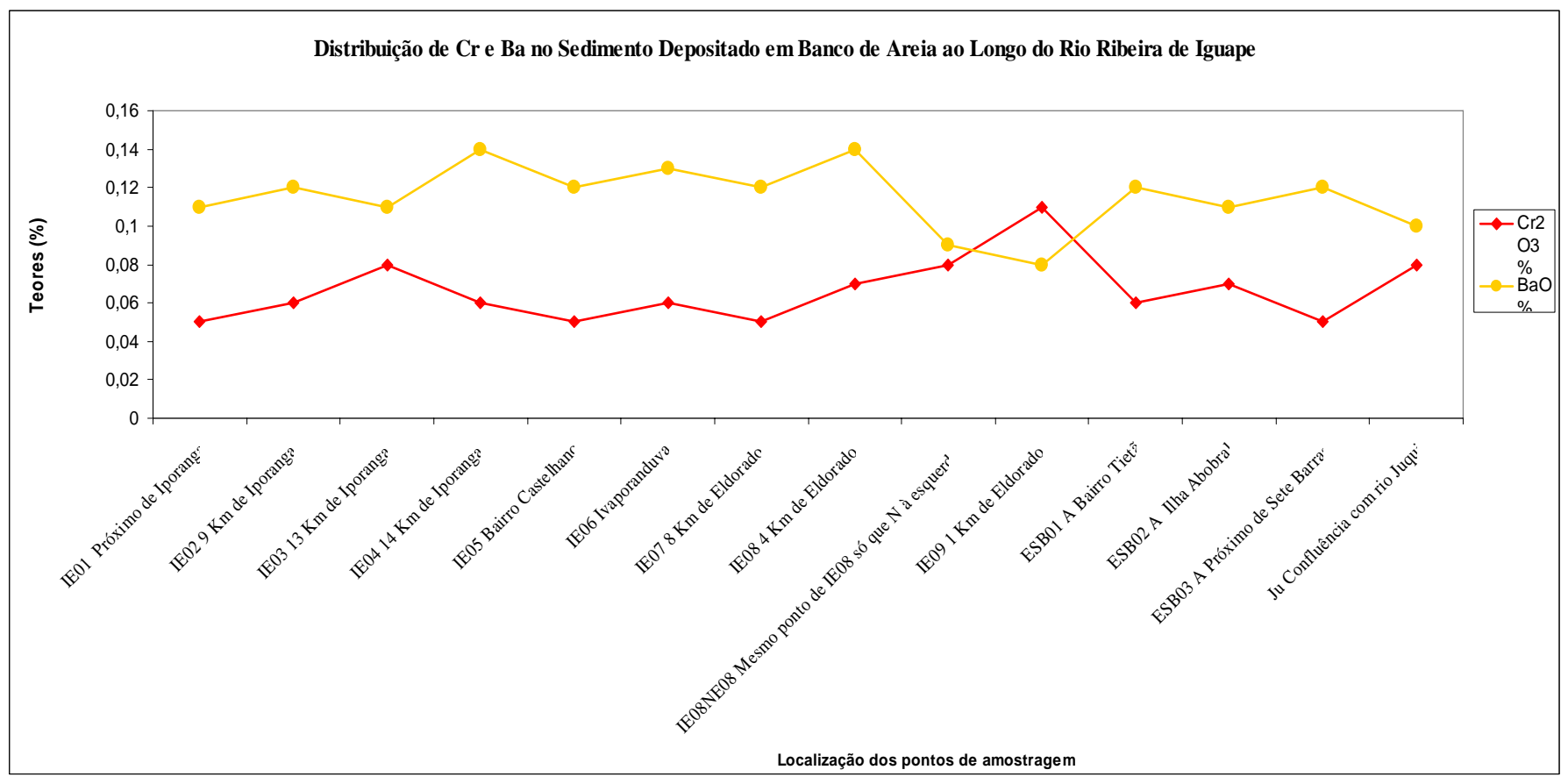

Gráfico 17 - Distribuição de Cr e Ba nas amostras de 0,20 m coletadas em bancos de areia ao longo do Rio Ribeira

No gráfico 17, nota-se que o Ba exibe enriquecimento nas amostras IE04 (14 km de Iporanga) e IE08 (4 km de Eldorado), enquanto que o $\mathrm{Cr}$ apresenta valores mais elevados para as amostras IE03 (13 km de Iporanga) e IE09 (1 km de Eldorado). Os teores mais baixos de Ba foram obtidos para as amostras IE09 (1 km de Eldorado), IE08NE08 (NE do IE08) e JU (Juquiá), enquanto que os de Cr aparecem para os pontos IE01 (próximo de Iporanga) e ESB03A (próximo de Sete Barras).

As maiores concentrações de Ba foram detectadas no intervalo de $0,20 \mathrm{~m}$ a 0,40 m, como observado para as amostras IE03, IE05, IE07, IE08NE08, ESB01C, ESB02B e ESB03A. No restante dos sedimentos o Ba concentra-se no topo das sondagens. Não foi verificada variação lateral para o $\mathrm{Ba}$, obedecendo à mesma tendência de concentração química em distintos pontos de um mesmo banco de areia.

$\mathrm{Na}$ maioria dos pontos de amostragem o $\mathrm{Cr}$ concentra-se na porção basal da sondagem, exceto para as amostras IE07, IE08NE08, ESB01C e JU. Para este metal, também não foi constatada variação lateral. 
Os valores de referência PEL/TEL foram empregados na verificação da provável contaminação do Cr nestes sedimentos, uma vez que se trata de um metal pesado (Gráfico 18). Nota-se neste gráfico, que para todas as amostras este elemento supera estes valores de referência, tanto de alerta (TEL) como de intervenção (PEL). Tal fato indica a necessidade de serem realizados estudos de acompanhamento e de detalhe que venham a implicar na provável mobilidade deste metal para o meio ambiente.

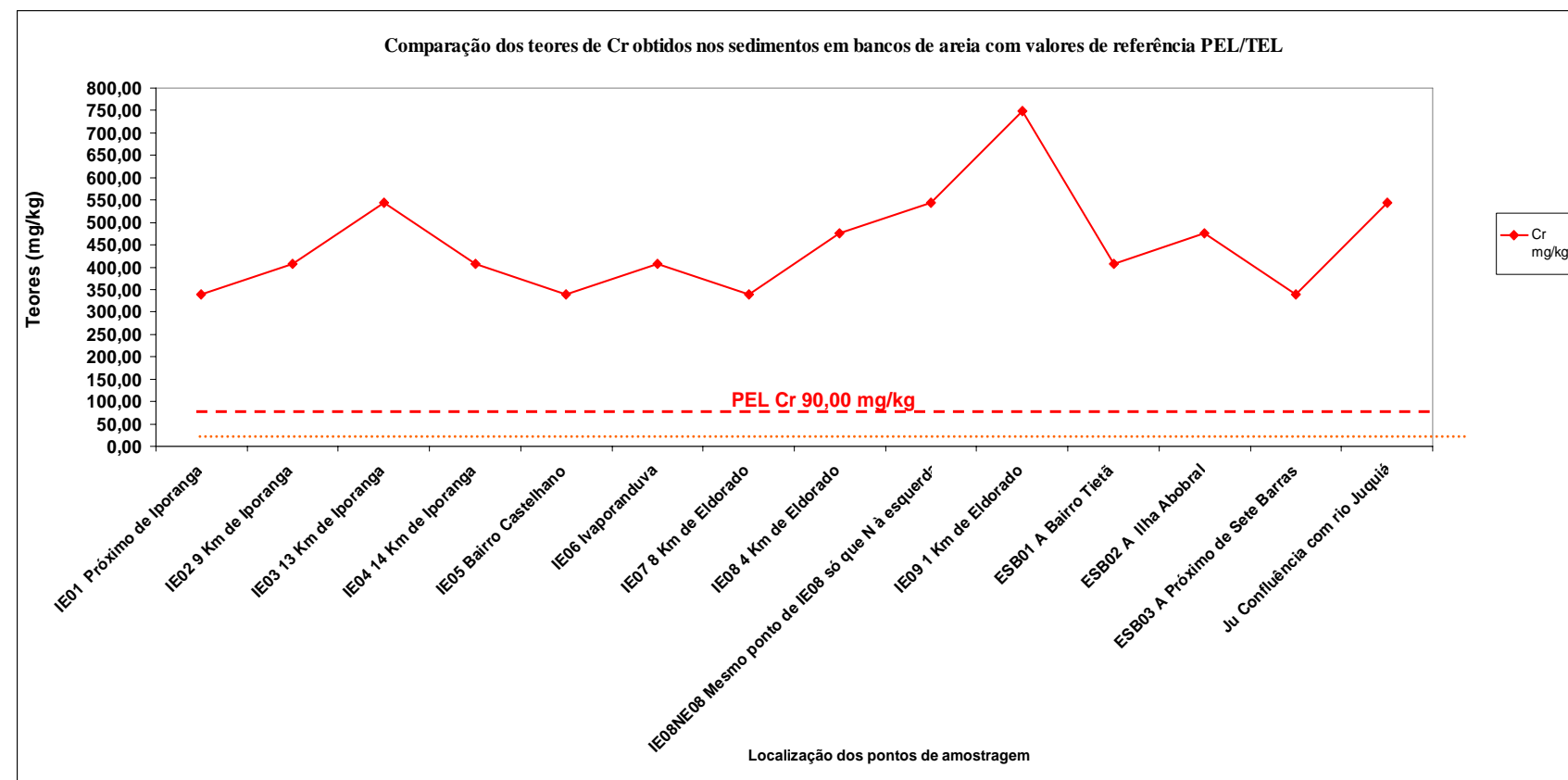

Gráfico 18 - Comparação de Cr com valores de referência PEL/TEL nos sedimentos depositados em bancos de areia

Nestes sedimentos o valor médio de $\mathrm{Cr}(484,63 \mathrm{mg} / \mathrm{kg})$ é até 5 vezes maior que o valor de referência PEL $(90,00 \mathrm{mg} / \mathrm{kg})$ para este metal, sendo que os maiores valores encontrados foram da ordem de 816mg/kg (ESB01C 0,40-0,60 m) e $7487 \mathrm{mg} / \mathrm{kg}$ (IE09 0-020 m, ESB01A 0,20-0,40 m; 0,40-0,60 m; 0,60-0,80 m e ESB01C 0,40-0,60 m).

Considerações sobre os resultados obtidos

Como comprovado pelas análises químicas totais, obtidas em FRX, os sedimentos depositados em bancos de areia apresentam metais pesados em sua composição ( $\mathrm{Pb}, \mathrm{Zn}$ e $\mathrm{Cr}$ ), sendo o teor de $\mathrm{Cr}$ o mais elevado. Estes teores de $\mathrm{Cr}$, possivelmente são provenientes das rochas (metamáficas/ultramáficas e complexo alcalino/ultrabásico) e não de uma contaminação por agentes antrópicos, isso pode ser constatado nos resultados encontrados nas análises do Rio Juquiá (branco analítico) cujos teores são equivalentes aos encontrados em toda bacia. Cabe ressaltar, que embora a análise tenha sido realizada por outro equipamento e o sedimento em questão seja o de corrente e não de banco de areia como o abordado neste item, no mapeamento geoquímico realizado por Lopes Jr. (2005), também 
foi constatado teores elevados deste metal (valores entre 108 a $168 \mathrm{mg} / \mathrm{kg}$ e >168 mg/kg), principalmente no segmento Iporanga-Eldorado.

Os teores de $\mathrm{Pb}$ e $\mathrm{Zn}$ estão acima dos valores de background regional e dos valores de referência PEL/TEL, indicando que estes foram enriquecidos por atividades antrópicas, sejam estas, lançamento dos resíduos das atividades de mineração e/ou pilhas de rejeitos do concentrado e escória depositados às margens do Rio Ribeira de Iguape.

De modo geral, as amostras localizadas nas proximidades de Iporanga são mais enriquecidas em $\mathrm{Pb}$ e $\mathrm{Zn}$, provavelmente pelas condições favoráveis para deposição destes metais (granulometria mais fina, 0,50\% de matéria orgânica e teores mais elevados de Ca e Mg que devem estar mantendo elevado o $\mathrm{pH}$ deste ambiente, provavelmente por existirem carbonatos em sua composição), enquanto que a partir de Sete Barras em direção a foz estes metais não são mais detectados nestes sedimentos. No trabalho realizado por Lopes Jr. (2005), os estudos realizados em overbank apontam para a mesma tendência aqui observada, ou seja, maiores concentrações de $\mathrm{Pb}$ e $\mathrm{Zn}$ no segmento Iporanga-Eldorado, sendo os valores determinados por este autor da mesma ordem que os apresentados no presente trabalho, muito embora estes dois tipos de amostras não representem materiais verdadeiramente semelhantes e passiveis de uma comparação direta.

Nota-se certa correlação entre os teores de metais pesados e a granulometria nos pontos IE 01, IE02 e IE03. Estas amostras são compostas por sedimentos mais finos que o restante da bacia hidrográfica aqui analisada e o teor de $\mathrm{Pb}$ e $\mathrm{Zn}$ detectados foram os mais elevados.

Outro fato evidente obtido nos resultados das análises químicas é a correlação de Ca-Mg com os metais, nos pontos onde Ca-Mg foram elevados os teores dos metais também se encontram elevados. Isso pode ser explicado, possivelmente pela deposição destes metais nestas localidades em conseqüência do $\mathrm{pH}$ do meio que é alcalino em decorrência da presença elevada de $\mathrm{Ca}$ e $\mathrm{Mg}$ os quais devem estar depositados na forma de carbonatos.

De todas as amostras analisadas foram notados e obtidos valores anômalos, principalmente de Ca e Mg para IE08NE08 (0,20-0,40 m). Neste material os teores de perda ao fogo também estavam elevados, o que possivelmente pode estar indicando um horizonte mais dolomítico, explicando assim o aumento nesta profundidade para estes elementos.

As amostras coletadas no Rio Juquiá não apresentaram metais pesados, com exceção do $\mathrm{Cr}$, indicando que os metais encontrados nos sedimentos do Rio Ribeira são realmente provenientes das atividades de mineração realizadas no Alto Vale. 


\subsubsection{Sondagem realizada em banco de areia}

Durante a fase de coleta dos sedimentos depositados em bancos de areia no Rio Ribeira de Iguape, um destes bancos chamou mais atenção em decorrência de sua espessura com mais de 4 metros (Figura 33) localizado a $14 \mathrm{~km}$ de Iporanga. Neste banco realizou-se amostragem de 3,0 $\mathrm{m}$ de profundidade com coleta de sedimentos no intervalo de $20 \mathrm{em} 20 \mathrm{~cm}$, as quais foram submetidas a análises químicas totais por FRX. Tal procedimento visou delimitar a contribuição histórica dos resíduos lançados neste rio durante o período de tempo de sua deposição.

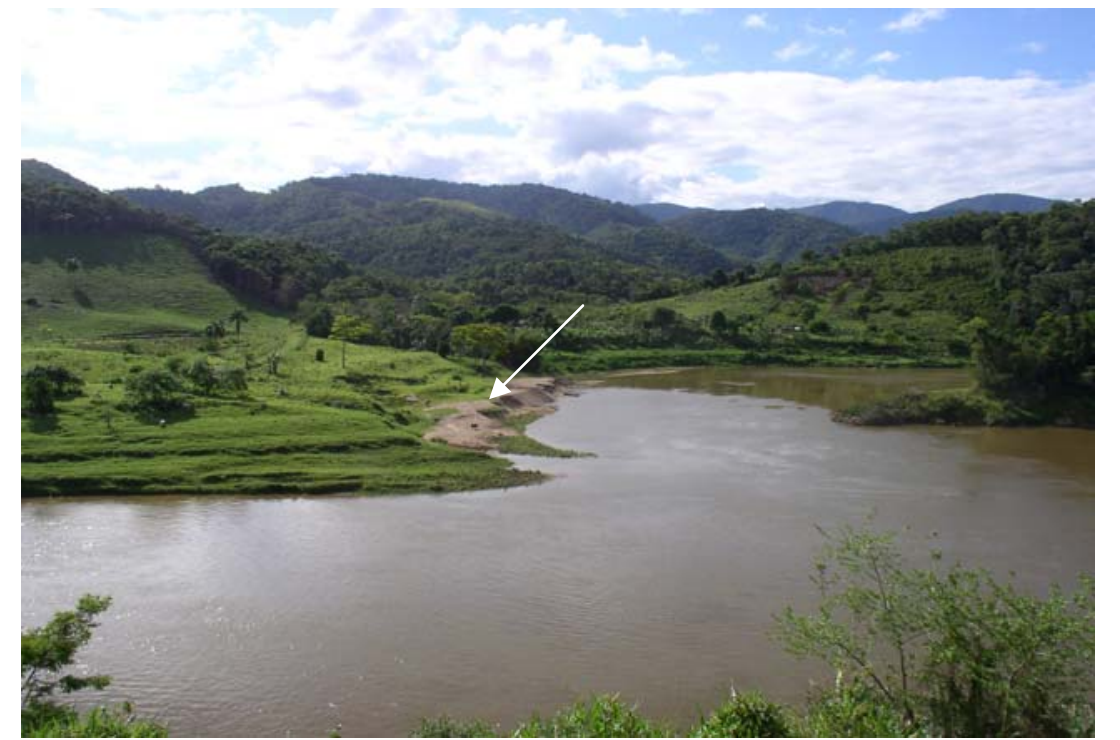

Figura 33 - Depósito em banco de areia - amostragem de 3,0 m de profundidade

Nestas amostras (perfil IE04) foram realizadas análises químicas totais por FRX, cujos teores médios detectados foram: 81,86\% $\%$ 0,72 de $\mathrm{SiO}_{2} ; 7,97 \% \pm 0,30$ de $\mathrm{Al}_{2} \mathrm{O}_{3}$; $3,28 \% \pm 0,15$ de $\mathrm{K}_{2} \mathrm{O} ; 2,97 \% \pm 0,41$ de $\mathrm{Fe}_{2} \mathrm{O}_{3}$ e 1,39\% $\pm 0,04$ de $\mathrm{Na}_{2} \mathrm{O}$, além de outros elementos com valores inferiores a $1 \%$ (Tabela 16). 
Tabela 16 - Análise química total dos sedimentos coletados em perfil 3 m de profundidade a 14 km de Iporanga - \% de óxidos

\begin{tabular}{|c|c|c|c|c|c|c|c|c|c|c|c|c|c|c|c|c|c|}
\hline $\begin{array}{c}\text { Amostra } \\
\text { Profundidade }\end{array}$ & $\begin{array}{c}\mathrm{SiO}_{2} \\
\%\end{array}$ & $\begin{array}{c}\mathrm{Al}_{2} \mathbf{O}_{3} \\
\%\end{array}$ & $\begin{array}{c}\mathrm{MnO} \\
\%\end{array}$ & $\begin{array}{c}\text { MgO } \\
\%\end{array}$ & $\begin{array}{c}\mathrm{CaO} \\
\%\end{array}$ & $\begin{array}{c}\mathrm{Na}_{2} \mathrm{O} \\
\%\end{array}$ & $\begin{array}{c}\mathbf{K}_{2} \mathbf{O} \\
\%\end{array}$ & $\begin{array}{c}\mathrm{TiO}_{2} \\
\%\end{array}$ & $\begin{array}{c}\mathbf{P}_{2} \mathbf{O}_{5} \\
\%\end{array}$ & $\begin{array}{c}\mathrm{SO}_{3} \\
\%\end{array}$ & $\begin{array}{c}\mathrm{Fe}_{2} \mathbf{O}_{3} \\
\%\end{array}$ & $\begin{array}{c}\mathrm{Cr}_{2} \mathrm{O}_{3} \\
\%\end{array}$ & $\begin{array}{c}\mathrm{BaO} \\
\%\end{array}$ & $\begin{array}{c}\mathrm{ZnO} \\
\%\end{array}$ & $\begin{array}{c}\text { PbO } \\
\%\end{array}$ & $\begin{array}{c}\text { Outros } \\
\%\end{array}$ & $\begin{array}{c}\text { Fechamento } \\
\%\end{array}$ \\
\hline IE04 (0-0,20m) & 80,60 & 8,03 & 0,07 & 0,87 & 0,97 & 1,40 & 3,07 & 0,85 & 0,08 & $<<$ & 3,72 & 0,06 & 0,14 & 0,02 & 0,02 & 0,06 & 99,96 \\
\hline IE04 $(0,20-0,40 m)$ & 82,70 & 7,89 & 0,09 & 0,59 & 0,72 & 1,42 & 3,47 & 0,37 & 0,07 & $<<$ & 2,43 & 0,06 & 0,13 & 0,01 & 0,02 & 0,06 & 100,03 \\
\hline IE04 (0,40-0,60m) & 82,90 & 7,67 & 0,08 & 0,58 & 0,71 & 1,43 & 3,33 & 0,41 & 0,07 & Nd & 2,53 & 0,07 & 0,16 & 0,02 & 0,01 & 0,06 & 100,03 \\
\hline IE04 $(0,60-0,80 \mathrm{~m})$ & 83,10 & 7,48 & 0,07 & 0,60 & 0,74 & 1,34 & 3,16 & 0,48 & 0,07 & Nd & 2,70 & 0,07 & 0,12 & 0,02 & 0,01 & 0,06 & 100,02 \\
\hline IE04 (0,80-1,0m) & 81,20 & 7,64 & 0,09 & 0,68 & 0,86 & 1,34 & 3,15 & 0,87 & 0,08 & 0,02 & 3,81 & 0,07 & 0,14 & 0,01 & 0,02 & 0,07 & 100,05 \\
\hline IE04 (1,0-1,2m) & 82,10 & 7,93 & 0,08 & 0,66 & 0,76 & 1,40 & 3,36 & 0,50 & 0,07 & $<<$ & 2,81 & 0,06 & 0,14 & 0,02 & 0,01 & 0,06 & 99,96 \\
\hline IE04 (1,2-1,4m) & 81,50 & 8,09 & 0,08 & 0,73 & 0,83 & 1,43 & 3,22 & 0,65 & 0,08 & $<<$ & 3,09 & 0,07 & 0,12 & 0,02 & 0,02 & 0,06 & 99,99 \\
\hline IE04 (1,4-1,6m) & 81,40 & 7,84 & 0,07 & 0,80 & 0,95 & 1,34 & 3,12 & 0,76 & 0,08 & 0,02 & 3,32 & 0,05 & 0,13 & 0,02 & 0,02 & 0,06 & 99,98 \\
\hline IE04 (1,6-1,8m) & 81,90 & 7,76 & 0,08 & 0,73 & 0,82 & 1,36 & 3,14 & 0,65 & 0,07 & $<<$ & 3,22 & 0,07 & 0,13 & 0,02 & 0,02 & 0,06 & 100,03 \\
\hline IE04 (1,8-2,0m) & 82,00 & 7,83 & 0,08 & 0,76 & 0,86 & 1,33 & 3,14 & 0,61 & 0,08 & Nd & 3,09 & 0,06 & 0,12 & 0,02 & 0,02 & 0,06 & 100,06 \\
\hline IE04 (2,0-2,2m) & 81,60 & 8,16 & 0,08 & 0,74 & 0,85 & 1,38 & 3,37 & 0,57 & 0,08 & $<<$ & 2,92 & 0,06 & 0,12 & 0,02 & 0,02 & 0,07 & 100,04 \\
\hline IE04 (2,2-2,4m) & 81,20 & 8,63 & 0,08 & 0,76 & 0,77 & 1,48 & 3,50 & 0,49 & 0,09 & $<<$ & 2,74 & 0,07 & 0,14 & 0,02 & 0,01 & 0,06 & 100,04 \\
\hline IE04 (2,4-2,6m) & 82,30 & 8,00 & 0,08 & 0,72 & 0,78 & 1,37 & 3,30 & 0,44 & 0,08 & 0,02 & 2,66 & 0,08 & 0,14 & 0,01 & 0,02 & 0,06 & 100,06 \\
\hline IE04 (2,6-2,8m) & 82,30 & 8,12 & 0,07 & 0,63 & 0,69 & 1,38 & 3,55 & 0,40 & 0,06 & $<<$ & 2,54 & 0,06 & 0,14 & 0,02 & 0,02 & 0,06 & 100,04 \\
\hline IE04 $(2,8-3,0 \mathrm{~m})$ & 81,10 & 8,48 & $\mathbf{0 , 0 8}$ & 0,83 & $\mathbf{0 , 8 8}$ & 1,39 & 3,28 & 0,60 & 0,08 & $<<$ & 3,01 & 0,05 & 0,13 & 0,02 & 0,02 & 0,05 & 100,00 \\
\hline $\begin{array}{c}\text { Média } \\
\end{array}$ & 81,86 & 7,97 & 0,08 & 0,71 & 0,81 & 1,39 & 3,28 & 0,58 & 0,08 & 0,02 & 2,97 & 0,06 & 0,13 & 0,02 & 0,02 & 0,06 & \\
\hline Erro & 0,19 & 0,08 & $\mathbf{0 , 0 0}$ & 0,02 & $\mathbf{0 , 0 2}$ & $\mathbf{0 , 0 1}$ & 0,04 & 0,04 & $\mathbf{0 , 0 0}$ & $\mathbf{0 , 0 0}$ & 0,11 & $\mathbf{0 , 0 0}$ & $\mathbf{0 , 0 0}$ & $\mathbf{0 , 0 0}$ & $\mathbf{0 , 0 0}$ & $\mathbf{0 , 0 0}$ & \\
\hline Desvio Padrão & 0,72 & 0,30 & 0,01 & 0,09 & 0,08 & 0,04 & 0,15 & 0,16 & 0,01 & 0,01 & 0,41 & 0,01 & 0,01 & 0,00 & 0,00 & 0,00 & \\
\hline
\end{tabular}

$<<$ : Traços (menor que 0,01\%)

Nd: Não detectado

Os elementos detectados neste perfil apresentaram variações dos teores com a profundidade. Destes elementos, os únicos que exibiram concentrações mais elevadas no mesmo patamar foram $\mathrm{Mn}$-Ti-Fe e $\mathrm{Ca}-\mathrm{Mg}$. Os maiores teores de $\mathrm{Mn}$, Ti e Fe estão concentrados no intervalo de $0,80 \mathrm{~m}$ a $1,0 \mathrm{~m}$ e os de $\mathrm{Ca}$ e $\mathrm{Mg}$ nos primeiros $20 \mathrm{~cm}$ do perfil (Tabela 16).

Nos 3,0 metros amostrados (perfil IE04) o teor de PbO e ZnO oscilou de 0,01\% a $0,02 \%$, sendo que na maior parte prevaleceu teores de $0,02 \%$ para estes dois metais pesados, como pode ser observado na tabela 16.

Nestes sedimentos os teores de $\mathrm{Cr}_{2} \mathrm{O}_{3}$ variaram de $0,05 \%$ a $0,08 \%$, estes valores oscilam de uma profundidade para outra de modo que o seu aumento ou decréscimo não é continuo (Tabela 16).

Seguindo o mesmo formato de apresentação e avaliação dos resultados apresentados para as sondagens de 60 centímetros ao longo do Rio Ribeira são mostrados a seguir os resultados obtidos para os elementos de interesse em três grupos assim delimitados: Ca-Mg-Fe; Pb-Zn e Cr-Ba.

$\underline{\mathrm{Ca}, \mathrm{Mg} \text { e Fe }}$

Os teores médios detectados para estes elementos foram: $\mathrm{CaO}$ de 0,81\%, $\mathrm{MgO}$ de 0,71\% e $\mathrm{Fe}_{2} \mathrm{O}_{3}$ de 2,97\% (Tabela 16). Com o intuito de verificar a distribuição destes elementos ao longo deste perfil de $3,0 \mathrm{~m}$ foi confeccionado o gráfico 19, o qual exibe curvas de tendências de concentrações químicas similares para estes elementos, com exceção para as profundidades 2,20 m e 2,40 m, onde Ca e $\mathrm{Mg}$ exibem tendência inversa. 


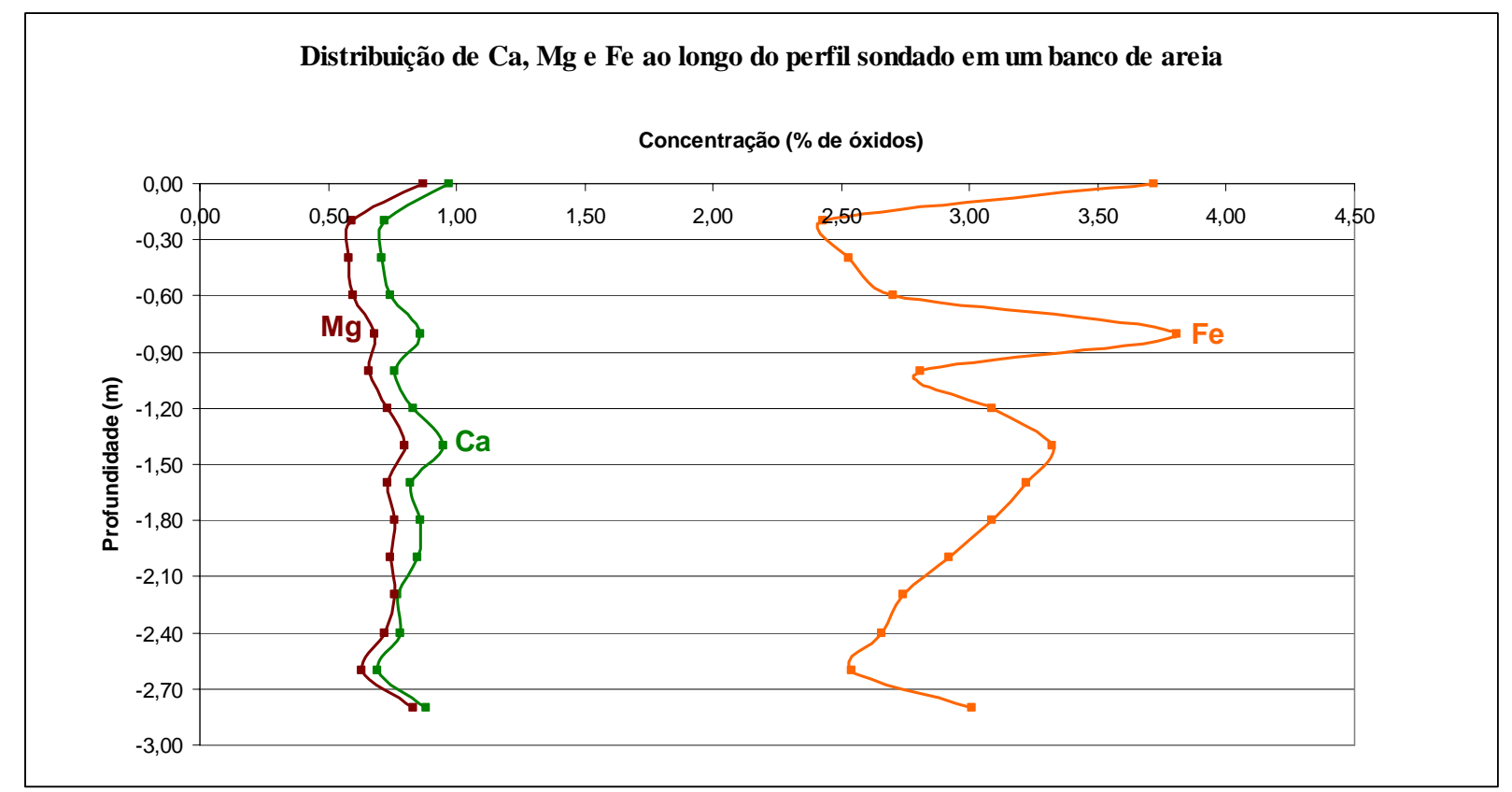

Gráfico 19 - Distribuição de Ca, Mg e Fe na sondagem de 3,0 m realizada a 14 km de Iporanga em banco de areia

Os valores de Ca e Mg não exibem tendência gradual de aumento ou decréscimo com a profundidade, variando bastante até atingir os 3,0 m (Gráfico 19). De modo geral, observa-se neste mesmo gráfico e na tabela 16 que os valores mais elevados de $\mathrm{Ca}$ e $\mathrm{Mg}$ concentram-se nos primeiros 20 centímetros e depois no horizonte de $1,4 \mathrm{~m}$, enquanto que os maiores teores de Fe aparecem na profundidade de $0,80 \mathrm{~m}$ e nos primeiros $20 \mathrm{~cm}$ (Gráfico 19 e tabela 16).

\section{$\underline{\mathrm{Pb} \text { e } \mathrm{Zn}}$}

Nestes sedimentos os teores médios de $\mathrm{Pb}$ e $\mathrm{Zn}$ foram de 161,20 mg/kg e de 144,00 $\mathrm{mg} / \mathrm{kg}$, respectivamente. Objetivando examinar a tendência de concentração química do $\mathrm{Pb}$ e Zn nesta amostragem de 3,0 m foi elaborado o gráfico 20. Neste gráfico, pode-se visualizar que as curvas de tendências das concentrações químicas do $\mathrm{Pb}$ e $\mathrm{Zn}$ são similares apenas para o intervalo de $1,2 \mathrm{~m}$ a 2,0 $\mathrm{m}$, no restante estas curvas apresentam tendência inversa. 


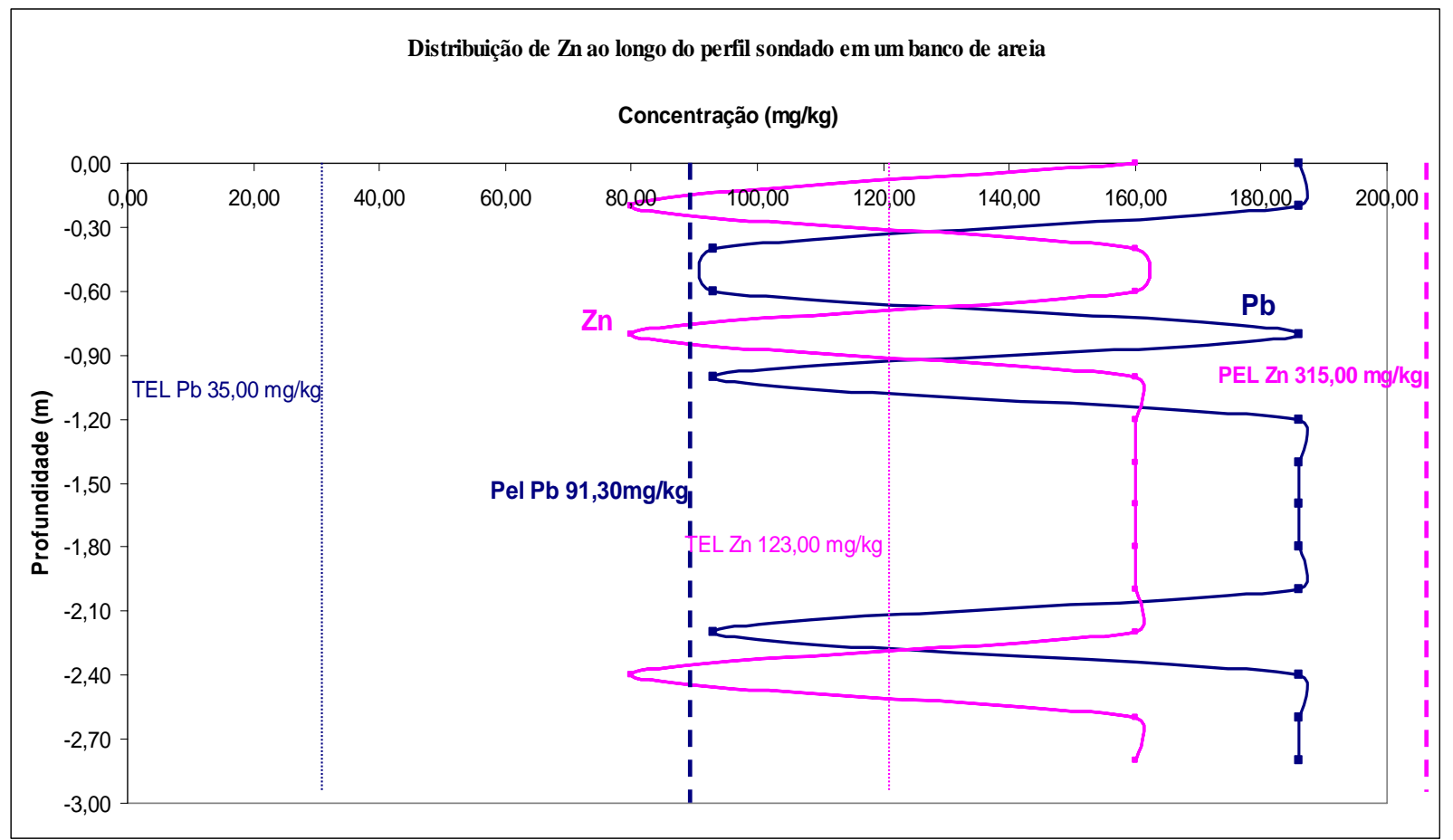

Gráfico 20 - Comparação do Pb e Zn com valor de referência PEL/TEL na amostragem de 3,0 m em banco de areia

Nota-se ainda no gráfico 20, que o teor de $\mathrm{Pb}$ ultrapassou os valores de referência TEL (TEL do Pb: 35,00 mg/kg) e PEL (PEL do Pb: 91,30 mg/kg) em todos os pontos amostrados. Neste mesmo gráfico, verifica-se que os teores de Zn não superaram o valor de referência PEL (PEL do Zn: 315,00 mg/kg). Estes ultrapassaram os valores de referência TEL (TEL do ZN: 123,00 mg/kg), com exceção das amostras coletadas nas profundidades 0,20 m; 0,80 m e 2,40 m (Gráfico 20). O valor de referência TEL representa alerta e PEL intervenção, os resultados aqui encontrados demonstram que devem ser executadas análises mais detalhadas e ser realizado monitoramento destes sedimentos para verificar possível disponibilidade destes dois metais para o meio ambiente.

\section{$\underline{B a}$ e $\mathrm{Cr}$}

Nesta sondagem o teor médio de $\mathrm{BaO}$ detectado foi de $0,13 \%$ e o de $\mathrm{Cr}_{2} \mathrm{O}_{3}$ foi de 0,06\%. Como realizado para o grupo do Ca-Mg-Fe e Pb-Zn foi confeccionado um gráfico de concentração química destes elementos nos 3,0 m amostrados (Gráfico 21). As curvas de tendência de concentração química do $\mathrm{Cr}$ e Ba mostram certa correspondência a partir do intervalo de 1,60 $\mathrm{m}$ até atingir os $3,0 \mathrm{~m}$, com exceção do ponto 2,60 $\mathrm{m}$ que tem tendência inversa. Do topo desta amostragem até a profundidade de 2,60 $\mathrm{m}$ as curvas de concentração química do $\mathrm{Ba}$ e $\mathrm{Cr}$ mostraram tendência inversamente proporcionais, em alguns pontos (Gráfico 21). 


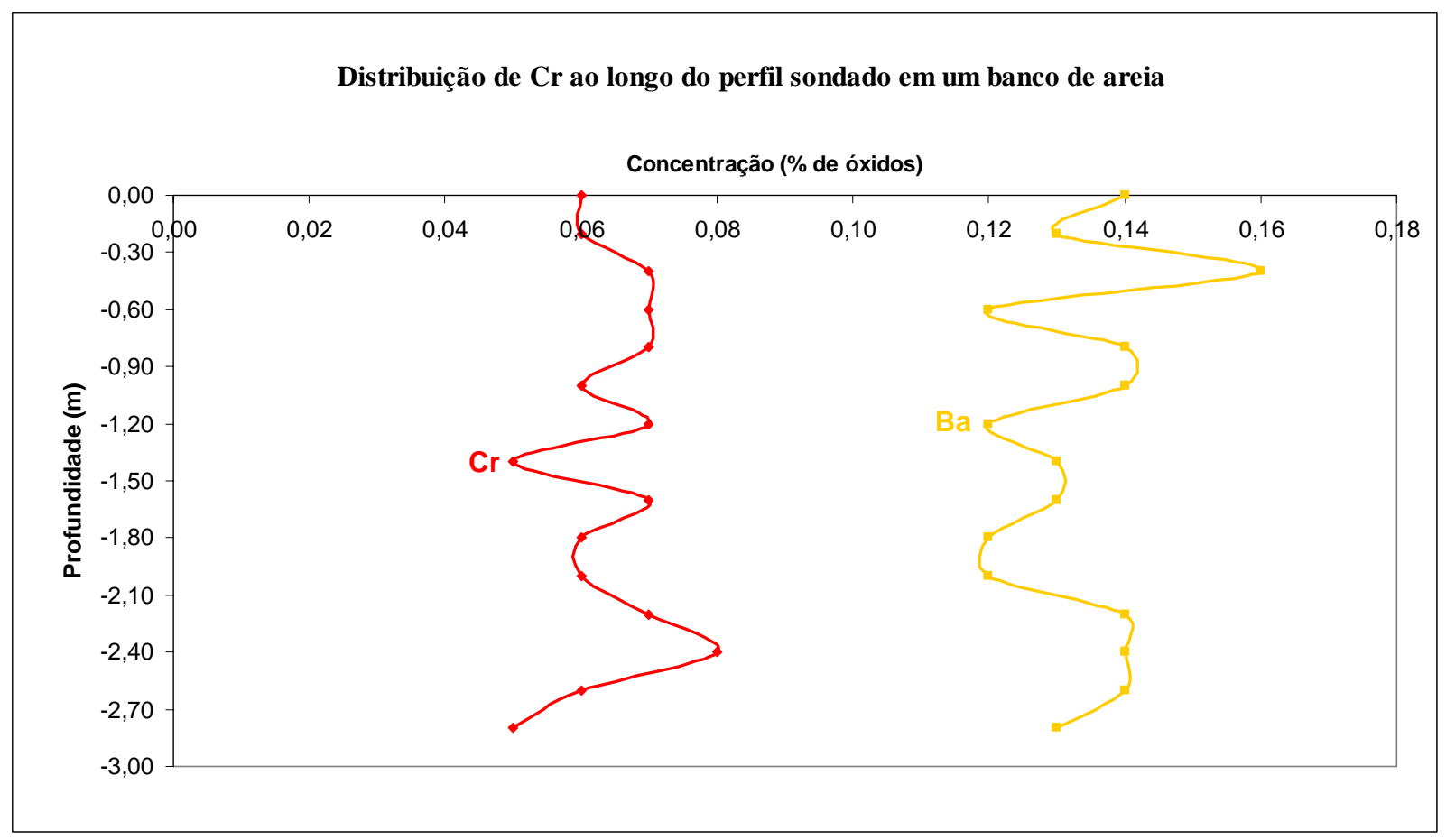

Gráfico 21 - Distribuição de Cr e Ba na sondagem de 3,0 m realizada a 14 km de Iporanga em banco de areia

Estes elementos concentram-se em profundidades distintas, a maior concentração de Ba ocorre na profundidade 0,40 m e a de $\mathrm{Cr}$ na profundidade de 2,40 m (Gráfico 21).

Como apresentado para os perfis de banco de areia coletados ao longo do Rio Ribeira, o teor de $\mathrm{Cr}$ foi convertido para $\mathrm{mg} / \mathrm{kg}$ e foi comparado com valor de referência PEL/TEL (Gráfico 22).

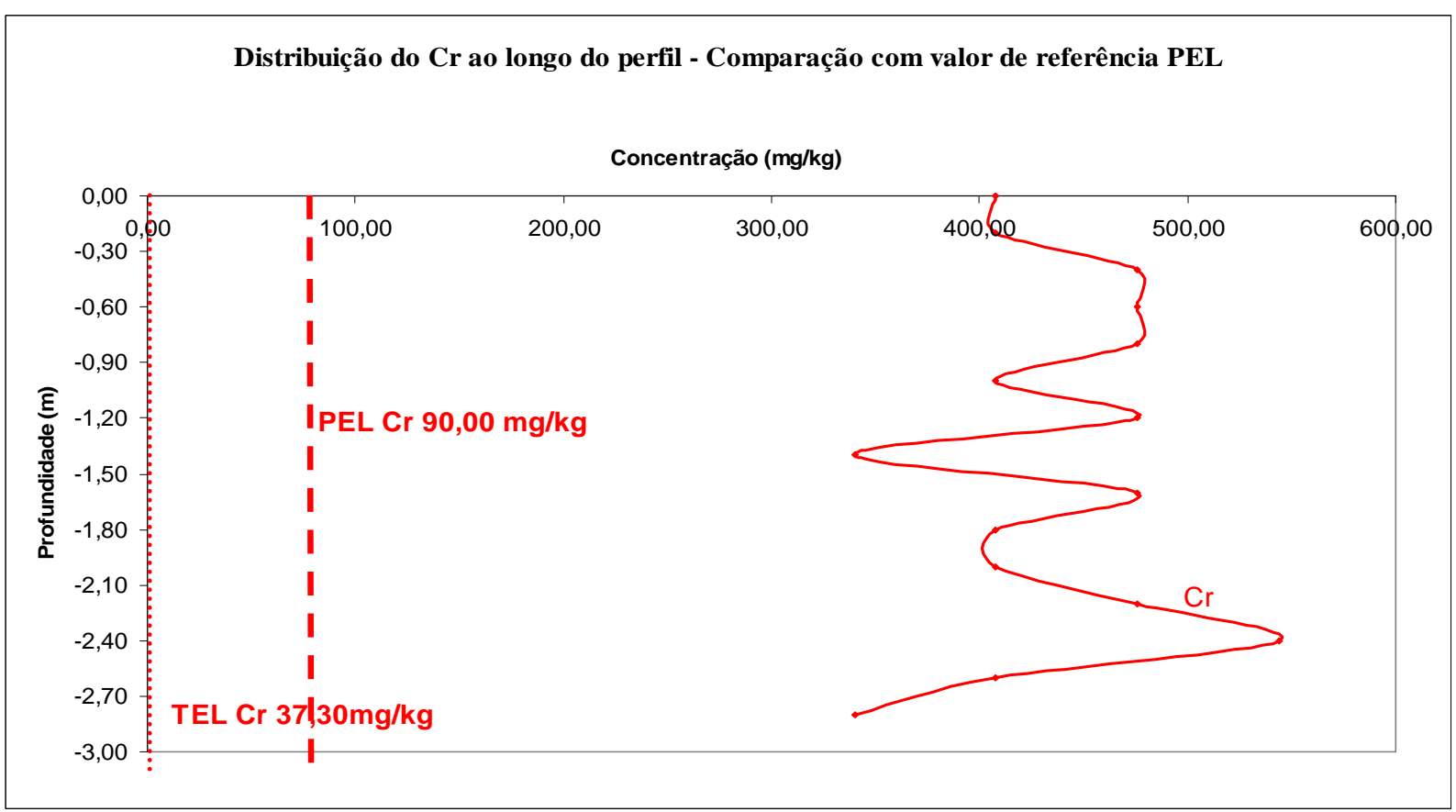

Gráfico 22 - Comparação do Cr detectado na sondagem de 3,0 m com valores de referência PEL/TEL 
Neste gráfico observa-se que para todas as amostras o teor de $\mathrm{Cr}$ supera os valores de referência PEL e TEL. O teor médio deste metal $(435,20 \mathrm{mg} / \mathrm{kg})$ ultrapassa em aproximadamente 5 vezes o valor de referência PEL $(90,00 \mathrm{mg} / \mathrm{kg})$, sendo o maior teor detectado na profundidade de 2,40 m (544,00 mg/kg), como indicado no gráfico 22.

\section{Considerações sobre os resultados obtidos}

Este estudo mostrou a necessidade de se fazer uma investigação detalhada, com a profundidade, em bancos de areia espessos, em decorrência da elevada variação nas concentrações dos elementos. As oscilações existentes nas concentrações dos elementos de um patamar para outro, pode estar relacionada com distintos regimes fluviais, os quais podem estar transportando e depositando materiais de diferentes concentrações dependendo da época de deposição.

Não foi observada clara correlação nos teores de Ca-Mg com os metais pesados, como verificado para as amostragens de 0,60 m, estes em alguns casos são inversamente proporcionais, dependendo do horizonte analisado.

Como verificado pelos resultados obtidos e tabulados em diversos diagramas, o $\mathrm{Pb}$ e Zn concentram-se em dois níveis distintos do perfil de sondagem de 1,20 m até 2,20 m e de 2,60 $\mathrm{m}$ até $3,0 \mathrm{~m}$, isso possivelmente pode estar ligado com a contribuição que o rio recebeu das atividades de mineração ocorridas em épocas mais antigas, uma vez que os sedimentos localizados nestas profundidades registram processo de sedimentação mais antigo do rio. $\mathrm{O}$ mesmo pode ser alinhavado para os elementos $\mathrm{Cr}$, $\mathrm{Ba}$, e para o grupo $\mathrm{Ca}, \mathrm{Mg}$ e $\mathrm{Fe}$.

Da mesma maneira que observado para as amostragens de $0,60 \mathrm{~m}$, os metais pesados de interesse $(\mathrm{Pb}, \mathrm{Zn}$ e $\mathrm{Cr}$ ), quando comparado com os valores de referência $\mathrm{PEL} / \mathrm{TEL}$ estão acima destes valores, exceto o $\mathrm{Zn}$, indicando que possivelmente trata-se de enriquecimento antrópico, necessitando estudo mais detalhado para verificação da disponibilidade e conseqüentemente grau de contaminação deste material.

Os teores de $\mathrm{Cr}$, como também observados para as coletas de $0,60 \mathrm{~m}$, possivelmente são provenientes da degradação intempérica e transporte de minerais primários resistentes (cromita, por exemplo) para a bacia hidrográfica analisada de diversas variedades de rochas (metamáficas/ultramáficas e Complexo alcalino/ultrabásico) e não de uma contaminação por agentes antrópicos.

\subsubsection{Sedimentos ativos de corrente}

Os sedimentos ativos de corrente foram coletados em Iporanga (SAC-IP), Eldorado (SAC-EL) e Sete Barras (SAC-SB). A fração inferior a 2,00 mm foi utilizada, parte na análise 
de extração parcial com água régia $\left(\mathrm{HNO}_{3} / \mathrm{HCl}\right)$ e parte na análise de digestão total (HF), sendo posteriormente analisadas em ICP/OES. Os resultados obtidos para os metais pesados $(\mathrm{Cd}, \mathrm{Cr}, \mathrm{Ni}, \mathrm{Cu}, \mathrm{Zn}$ e $\mathrm{Pb})$ e para o $\mathrm{Ba}$ nestes dois tratamentos químicos são apresentados na tabela 17.

Tabela 17 - Metais pesados e Ba detectados nos sedimentos ativos de corrente: Digestão Total (ataque com ácido fluorídrico) e Extração Parcial (ataque com água régia). Análise em ICP/OES

\begin{tabular}{|c|c|c|c|c|c|c|c|}
\hline \multicolumn{8}{|c|}{ Digestão Total (HF) } \\
\hline Amostras & $\begin{array}{c}\mathrm{Cd} \\
\mathrm{mg} / \mathrm{kg}\end{array}$ & $\begin{array}{c}\mathrm{Cr} \\
\mathrm{mg} / \mathrm{kg}\end{array}$ & $\begin{array}{c}\mathrm{Ni} \\
\mathrm{mg} / \mathrm{kg}\end{array}$ & $\begin{array}{c}\mathrm{Cu} \\
\mathrm{mg} / \mathrm{kg}\end{array}$ & $\begin{array}{c}\mathrm{Zn} \\
\mathrm{mg} / \mathrm{kg}\end{array}$ & $\begin{array}{c}\mathrm{Pb} \\
\mathrm{mg} / \mathrm{kg}\end{array}$ & $\begin{array}{c}\mathrm{Ba} \\
\mathrm{mg} / \mathrm{kg}\end{array}$ \\
\hline SAC-IP & 0,70 & 20,80 & 16,00 & 18,80 & 154,20 & 87,40 & 718,50 \\
\hline SAC-EL & $<<$ & 15,61 & 15,16 & 9,62 & 69,25 & 54,70 & 1177,00 \\
\hline SAC-SB & 0,50 & 14,10 & 15,30 & 9,79 & 70,73 & 38,72 & 872,00 \\
\hline \multicolumn{8}{|c|}{ Extração Parcial (Água Régia) } \\
\hline Amostras & $\begin{array}{c}\mathrm{Cd} \\
\mathrm{mg} / \mathrm{kg}\end{array}$ & $\begin{array}{c}\mathrm{Cr} \\
\mathrm{mg} / \mathrm{kg}\end{array}$ & $\begin{array}{c}\mathrm{Ni} \\
\mathrm{mg} / \mathrm{kg}\end{array}$ & $\begin{array}{c}\mathrm{Cu} \\
\mathrm{mg} / \mathrm{kg}\end{array}$ & $\begin{array}{c}\mathrm{Zn} \\
\mathrm{mg} / \mathrm{kg}\end{array}$ & $\begin{array}{c}\mathrm{Pb} \\
\mathrm{mg} / \mathrm{kg}\end{array}$ & $\begin{array}{c}\mathrm{Ba} \\
\mathrm{mg} / \mathrm{kg}\end{array}$ \\
\hline SAC-IP & $<<$ & 19,90 & 13,69 & 17,90 & 154,20 & 86,90 & 91,30 \\
\hline SAC-EL & $<<$ & 8,88 & 13,14 & 7,20 & 57,07 & 49,74 & 60,02 \\
\hline SAC-SB & $<<$ & 14,05 & 12,49 & 7,49 & 70,33 & 36,11 & 73,10 \\
\hline
\end{tabular}

Tanto na digestão total como na extração parcial foram detectados os seguintes metais pesados: $\mathrm{Cr}, \mathrm{Ni}, \mathrm{Cu}, \mathrm{Zn}$ e $\mathrm{Pb}$ (Tabela 17). Nesta mesma tabela, verifica-se que o $\mathrm{Cd}$ só foi quantificado nas amostras cuja metodologia empregada foi a digestão total. Os teores de metais pesados obtidos nas análises de digestão total foram mais elevados que nas de extração parcial, como esperado.

Nos dois procedimentos aqui adotados observa-se serem os sedimentos de corrente coletados em Iporanga mais enriquecidos em metais pesados que os coletados em Eldorado e Sete Barras (Tabela 17).

Nas análises de digestão total, o $\mathrm{Cr}$ e $\mathrm{Pb}$ exibiram tendência gradual de diminuição de concentração das amostras coletadas do município de Iporanga para o de Sete Barras (Tabela 17). Este mesmo comportamento não foi verificado para o $\mathrm{Ni}, \mathrm{Cu}$ e $\mathrm{Zn}$ que apresentaram teores similares nas amostras coletadas em Eldorado e Sete Barras, não exibindo queda de concentração ao longo das amostras coletadas no leito do Rio Ribeira de um município para o outro, como visualizado na tabela 17.

Como indicativo do possível grau de eficiência da extração parcial foram confeccionados gráficos em colunas com os teores de metais pesados detectados pelos dois métodos, para cada uma das amostras (Gráficos 23, 24 e 25). 
Nos sedimentos coletados em Iporanga, a recuperação dos teores de $\mathrm{Zn}, \mathrm{Cr}, \mathrm{Pb}$ e Cu empregando a extração com água régia ultrapassaram $90 \%$ do total obtido quando do uso do método de digestão total, como verificado no gráfico 23 e tabela 17.

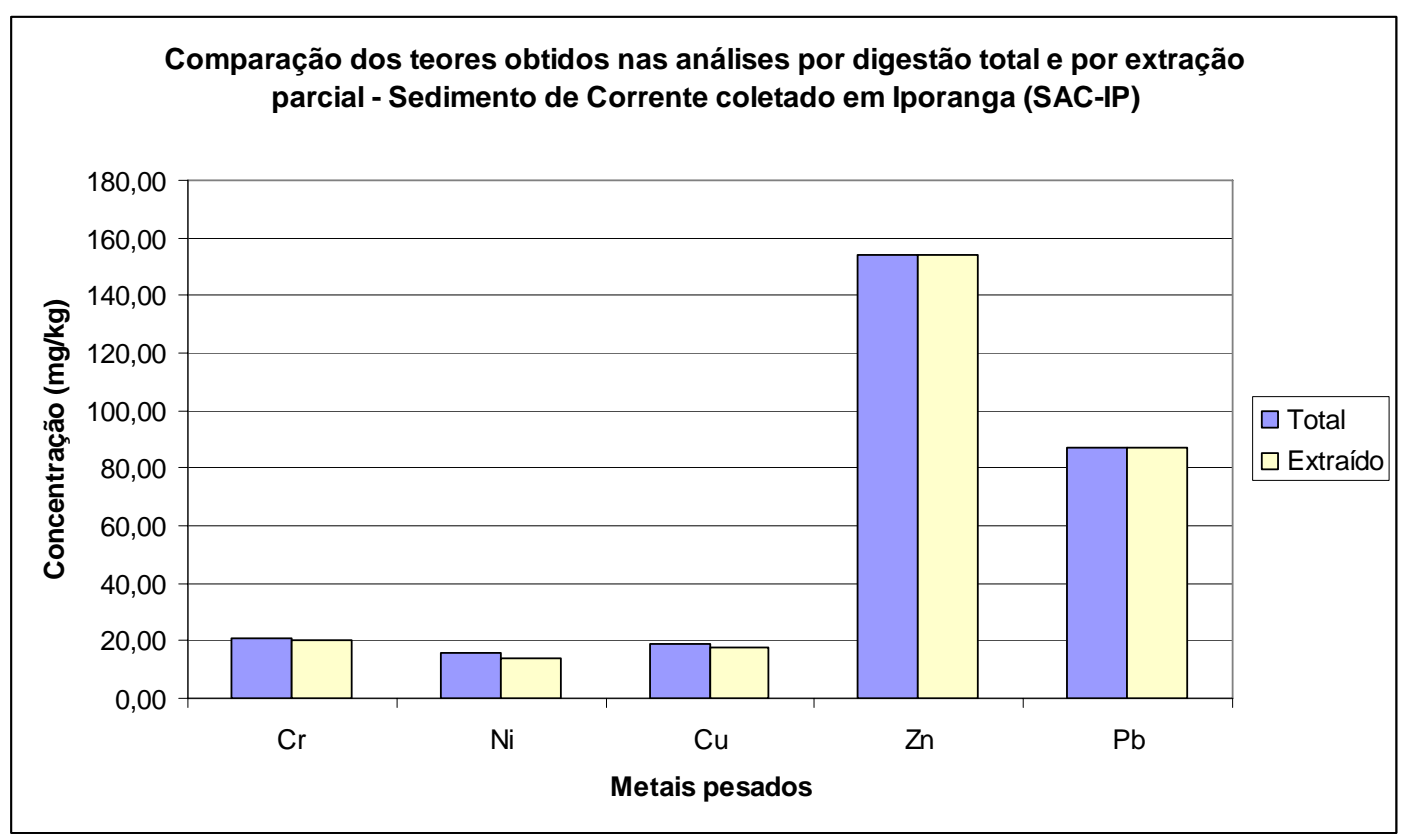

Gráfico 23 - Comparação dos teores de $\mathrm{Cr}, \mathrm{Ni}, \mathrm{Cu}, \mathrm{Zn}$ e Pb nas análises por digestão total e por extração parcial - Sedimento de Corrente coletado em Iporanga (SAC-IP)

Os sedimentos de corrente coletados em Eldorado exibiram comportamento químico distinto dos coletados em Iporanga, ou seja, o grau de recuperação destes metais pesados usando extração com água régia foi em média de $78 \%$ do total obtido na análise por digestão total (Gráfico 24). O Pb e Ni, dentre os metais pesados analisados nas amostras de Eldorado, exibiram teores similares nos dois procedimentos adotados, enquanto que os teores de $\mathrm{Cr}$, Cu e Zn foram menores nas análises de extração parcial que nas de digestão total (Gráfico 24). 


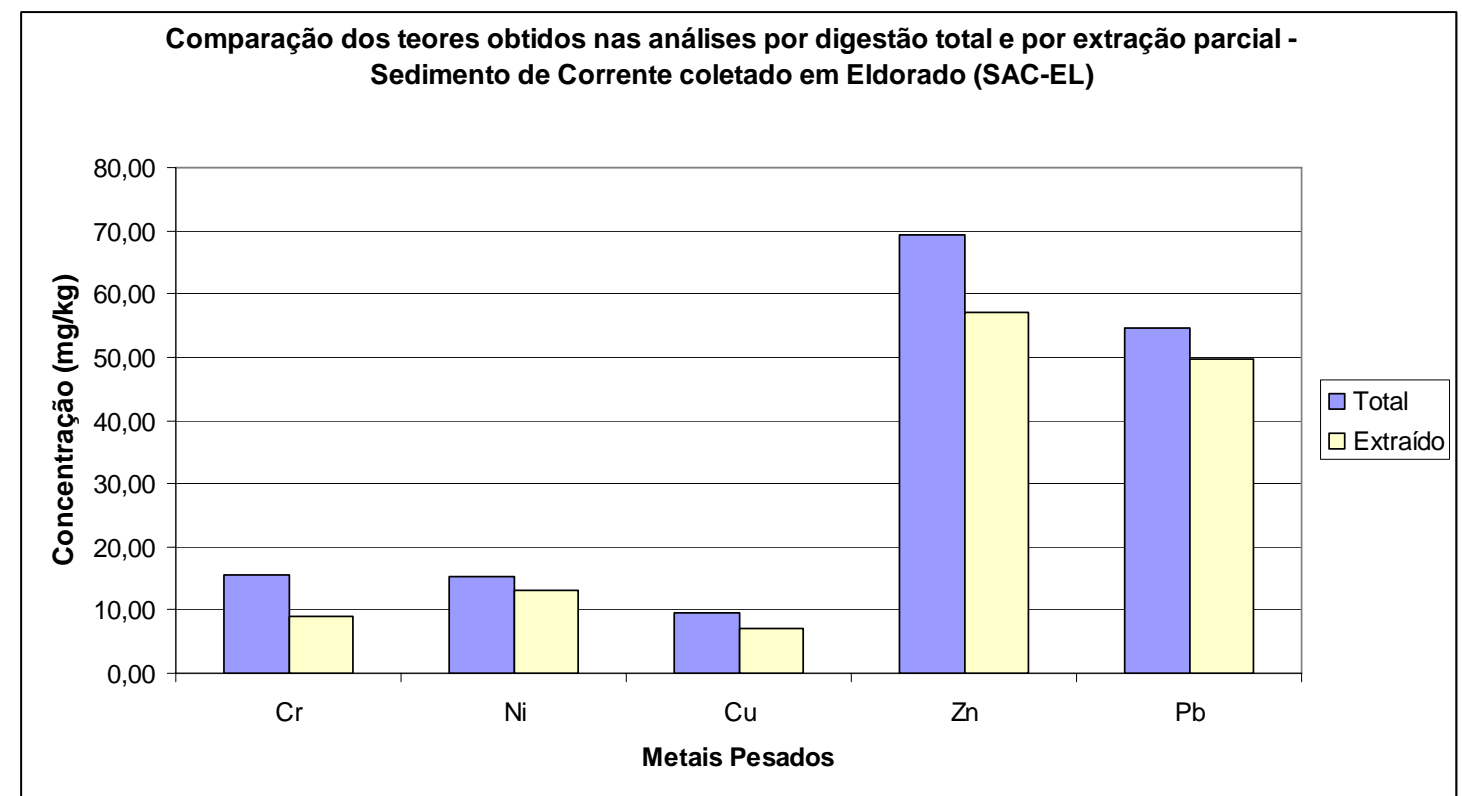

Gráfico 24 - Comparação dos teores de $\mathrm{Cr}, \mathrm{Ni}, \mathrm{Cu}, \mathrm{Zn}$ e $\mathrm{Pb}$ nas análises por digestão total e por extração parcial - Sedimento de Corrente coletado em Eldorado (SAC-EL)

Nas amostras coletadas em Sete Barras, os teores de Zn e Cr detectados, tanto na análise de digestão total como na extração parcial, foram bem similares (Tabela 17 e Gráfico 25). Por outro lado as concentrações de $\mathrm{Ni}$, $\mathrm{Cu}$ e $\mathrm{Pb}$ foram menores no método de extração parcial, como indicado no gráfico 25. O grau de recuperação destes metais pesados usando extração com água régia foi em média de $90 \%$ do total obtido na análise digestão total.

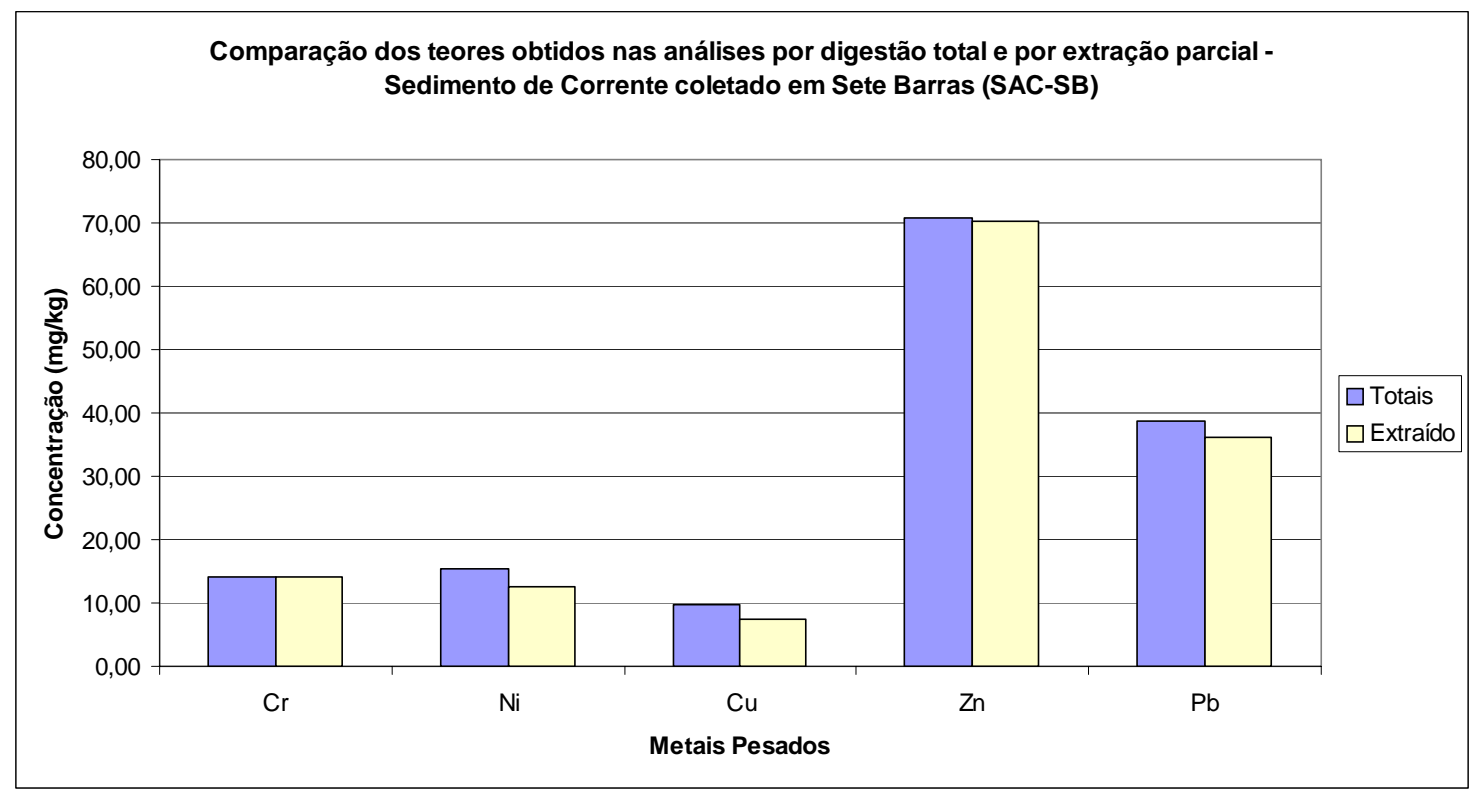

Gráfico 25 - Comparação dos teores de $\mathrm{Cr}, \mathrm{Ni}$, Cu, Zn e Pb nas análises por digestão total e por extração parcial - Sedimento de Corrente coletado em Sete Barras (SAC-SB) 
Dos metais investigados, o $\mathrm{Pb}$ foi o único a exibir teores acima do valor de referência TEL (TEL do Pb é de 35,00 mg/kg, representando valor de alerta para este elemento), para todas as amostras e para os teores obtidos pelos dois métodos. O Zn só ultrapassou o valor de referência TEL (TEL do Zn é de 123,00 mg/kg) para a amostra coletada em Iporanga, nos dois procedimentos químicos. Os outros metais pesados estão abaixo destes dois valores de referência para sedimento.

De todos os elementos investigados o que chamou mais atenção foi o $\mathrm{Ba}$, como pode ser observado na tabela 17 e gráfico 26, pois este exibe variações elevadas nas concentrações, quando comparado os dois métodos de análise química. Os teores de $\mathrm{Ba}$ detectados nas amostras onde foram utilizados métodos de ataque total foram imensamente mais elevados que nas amostras onde foram usados métodos de extração parcial (Gráfico 26). Na amostra coletada em Iporanga o teor de Ba é 8 vezes maior para extração total que para extração parcial, em Eldorado está diferença é de até 19 vezes e em Sete Barras é de 12 vezes (Tabela 17). A amostra coletada em Eldorado apresentou maior teor de Ba (1.177 $\mathrm{mg} / \mathrm{kg}$ ), quando do emprego da extração total (Tabela 17).

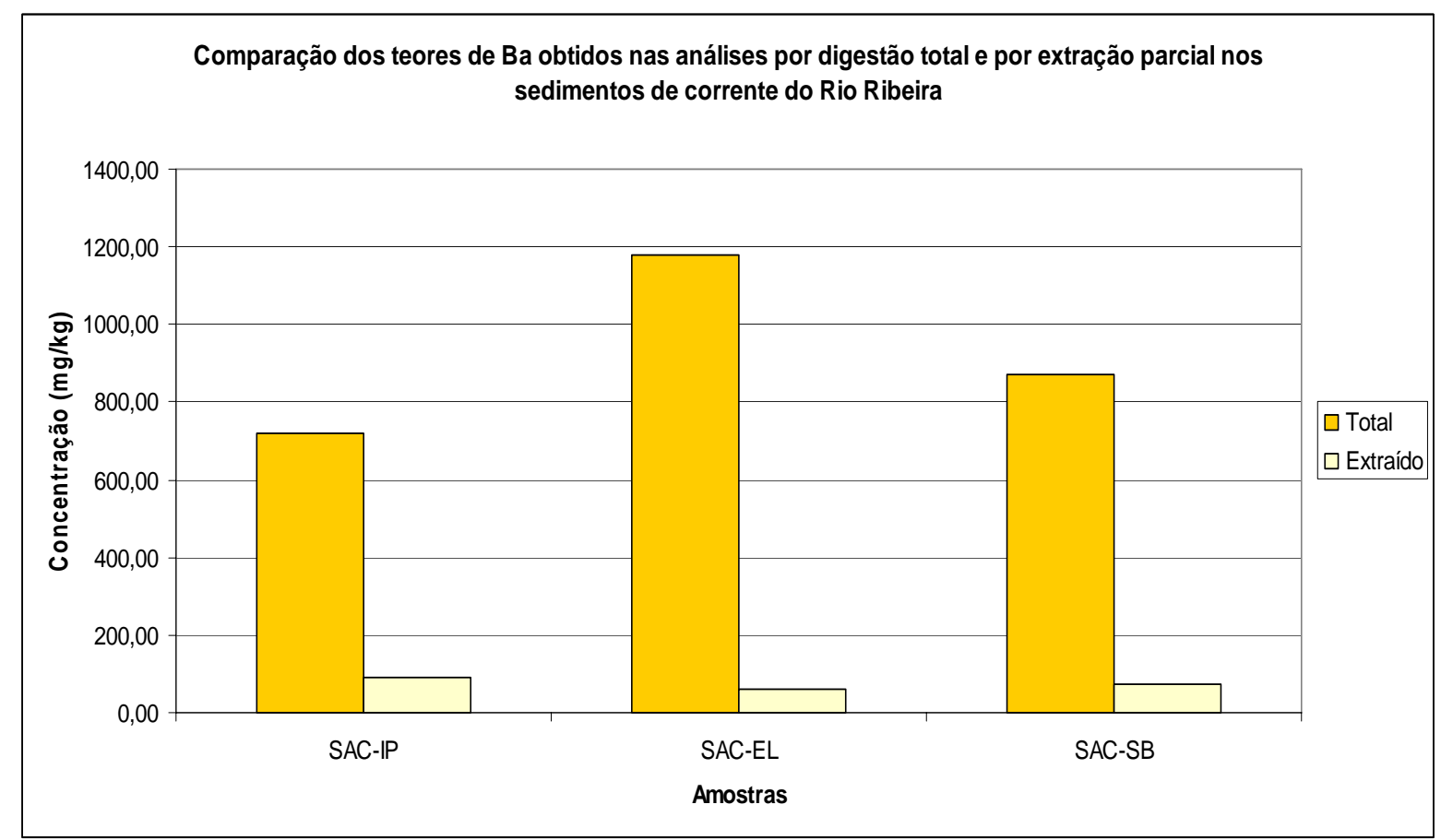

Gráfico 26 - Comparação dos teores de Ba nas análises por digestão total e por extração parcial, nos sedimentos de corrente do Rio Ribeira de Iguape 
Além dos metais pesados, também foram analisados para os dois métodos, os elementos maiores, como exibe a tabela 18.

Tabela 18 - Elementos maiores detectados nos sedimentos ativos de corrente: Digestão Total (ataque com ácido fluorídrico) e Extração Parcial (ataque com água régia). Análise em ICP/OES

Digestão Total (HF) \%

\begin{tabular}{|c|c|c|c|c|c|c|c|}
\hline Amostras & MnO & $\mathrm{CaO}$ & $\mathrm{MgO}$ & $\mathrm{Na}_{2} \mathrm{O}$ & $\mathrm{Al}_{2} \mathrm{O}_{3}$ & $\mathrm{Fe}_{2} \mathrm{O}_{3}$ & $\mathrm{~K}_{2} \mathrm{O}$ \\
\hline SAC-IP & 0,08 & 0,60 & 0,40 & 1,00 & 3,27 & 2,40 & 2,35 \\
\hline SAC-EL & 0,06 & 0,50 & 0,19 & 1,02 & 1,26 & 0,36 & 1,92 \\
\hline SAC-SB & 0,07 & 0,46 & 0,41 & 1,00 & 2,38 & 2,31 & 2,34 \\
\hline \multicolumn{8}{|c|}{ Extração Parcial (Água Régia) \% } \\
\hline Amostras & MnO & $\mathrm{CaO}$ & $\mathrm{MgO}$ & $\mathrm{Na}_{2} \mathrm{O}$ & $\mathrm{Al}_{2} \mathrm{O}_{3}$ & $\mathrm{Fe}_{2} \mathrm{O}_{3}$ & $\mathrm{~K}_{2} \mathrm{O}$ \\
\hline SAC-IP & 0,07 & 0,25 & 0,40 & 0,03 & 1,71 & 2,00 & 0,22 \\
\hline SAC-EL & 0,06 & 0,11 & 0,15 & 0,02 & 0,85 & 0,10 & 0,11 \\
\hline SAC-SB & 0,06 & 0,16 & 0,24 & 0,02 & 1,34 & 1,00 & 0,12 \\
\hline
\end{tabular}

Na tabela 18, nota-se que tanto na digestão total como na extração parcial, os sedimentos de corrente coletados em Iporanga são mais enriquecidos em $\mathrm{MnO}, \mathrm{CaO}, \mathrm{MgO}$, $\mathrm{Al}_{2} \mathrm{O}_{3}, \mathrm{Fe}_{2} \mathrm{O}_{3}$ e $\mathrm{K}_{2} \mathrm{O}$ que os de Eldorado e Sete Barras, obedecendo mesma tendência observada para os metais pesados.

A variação dos teores de $\mathrm{MnO}, \mathrm{MgO}, \mathrm{Al}_{2} \mathrm{O}_{3}, \mathrm{Fe}_{2} \mathrm{O}_{3}$ e $\mathrm{K}_{2} \mathrm{O}$ ao longo do Rio Ribeira não é gradual, sendo que estes elementos apresentam-se em menores concentrações nas amostras de sedimentos de corrente coletadas em Eldorado que as de Sete Barras (Tabela 18).

$\mathrm{Na}$ tabela 18, nota-se que as concentrações de $\mathrm{Na}$ e $\mathrm{K}$ recuperados pelo método de extração parcial é bastante inferior à detectada pela digestão total. Os valores de Na são 5 vezes e os de $\mathrm{K}$ até 14 vezes mais elevados na digestão total que na extração parcial. O Ca obedece esta mesma tendência, sendo seu teor 3 vezes maior na digestão total do que na extração parcial.

\section{Considerações sobre os resultados obtidos}

De acordo com Teódulo et al. (2003), este método de extração parcial é ainda hoje o mais indicado por diversos autores, pois a dissolução da amostra ocorre com o mínimo de ataque da estrutura dos silicatos detríticos, além de conseguir uma recuperação significativa dos metais pesados. Este método foi aplicado na presente pesquisa como um indicativo da possível disponibilidade dos metais pesados para biota, os quais serão efetivamente concluídos com os dados das análises químicas em tecidos de biomonitores (Corbicula 
fluminea) a ser apresentado no capítulo especifico de Biomonitor, sendo mais um comparativo para os dados obtidos nas análises cujo procedimento foi a digestão total. Desta forma os resultados obtidos nas análises com extração parcial e de digestão total servem como parâmetro inicial de possível indicação da disponibilidade ou não destes metais pesados para o meio ambiente.

Nos dois métodos empregados, tanto extração total como parcial foram detectados $\mathrm{Cr}, \mathrm{Ni}, \mathrm{Zn}, \mathrm{Cu}$ e $\mathrm{Pb}$ nos sedimentos de corrente coletados em Iporanga, Eldorado e Sete Barras. Estes metais pesados apresentaram concentrações maiores nas amostras coletadas em Iporanga, mesmo fato anteriormente observado para as análises realizadas em sedimentos depositados em bancos de areia, isso possivelmente está relacionado com a proximidade deste ponto de coleta com as áreas de depósitos de resíduos.

Resultados analíticos apresentados em Lopes Jr. (2005), em estudos realizados em sedimentos ativos de corrente, apontam para a mesma tendência aqui observada, ou seja, maiores concentrações de $\mathrm{Pb}$ e $\mathrm{Zn}$ no segmento Iporanga-Eldorado, sendo que os valores obtidos por este autor tendem a apresentar a mesma ordem de grandeza que os identificados no presente trabalho. Mesmo considerando que estes dois tipos de amostras não representem materiais verdadeiramente semelhantes e passiveis de uma comparação direta.

$\mathrm{O} \mathrm{Pb}$ e Cr demonstram visível queda de concentração de Iporanga até Sete Barras, principalmente quando da análise das amostras por digestão total, o que possivelmente indica um enriquecimento de origem antrópica destes metais nestes sedimentos. Tal constatação deve provir, com bastante segurança, em função das atividades de mineração ocorridas no Vale do Ribeira as quais encontram-se mais próximas do município de Iporanga do que dos restantes.

O Cd não foi detectado nas análises de extração parcial, possivelmente este metal pesado não está na forma biodisponível, e sim na fração residual das estruturas dos minerais, necessitando de estudos mais detalhados para uma diagnose precisa a respeito deste aspecto.

Nestes sedimentos os valores dos metais pesados analisados neste trabalho encontram-se abaixo do valor de referência PEL (considerado de intervenção), ao contrário do que foi visto para o sedimento em banco de areia, onde $\mathrm{Pb}$ e Cr estavam acima deste valor. Ainda conforme comparação com este valor de referência, o $\mathrm{Pb}$ detectado no sedimento ativo de corrente esta acima do valor TEL. 
Para o $\mathrm{Cr}, \mathrm{Cu}, \mathrm{Zn}$ e $\mathrm{Pb}$ os teores detectados nestes sedimentos de correntes são inferiores aos detectados nos sedimentos em bancos de areia, como foi exibido no capítulo de resultados dos sedimentos depositados em bancos de areia.

Provavelmente, a baixa quantificação dos teores de $\mathrm{Ba}, \mathrm{K}, \mathrm{Na}$, e em menor grau o $\mathrm{Ca}$, nas análises de extração parcial quando comparados com a digestão total, deve ser decorrência de estes elementos encontrarem-se na fração residual das estruturas dos minerais.

\subsubsection{Sedimentos em suspensão}

Os sedimentos em suspensão foram coletados em tanques de decantação em quatro unidades de extração de areia (portos de areia) localizadas em Eldorado, Sete Barras, Registro e Iguape, no leito do Rio Ribeira de Iguape.

Estes sedimentos apresentaram pH médio de 6,75. As amostras coletadas em Eldorado e Sete Barras apresentaram valores mais alcalinos $(\mathrm{pH}$ aproximadamente 7,0$)$ do que as de Registro e Iguape (pH entre 6,0 e 6,90), como observado no gráfico abaixo.

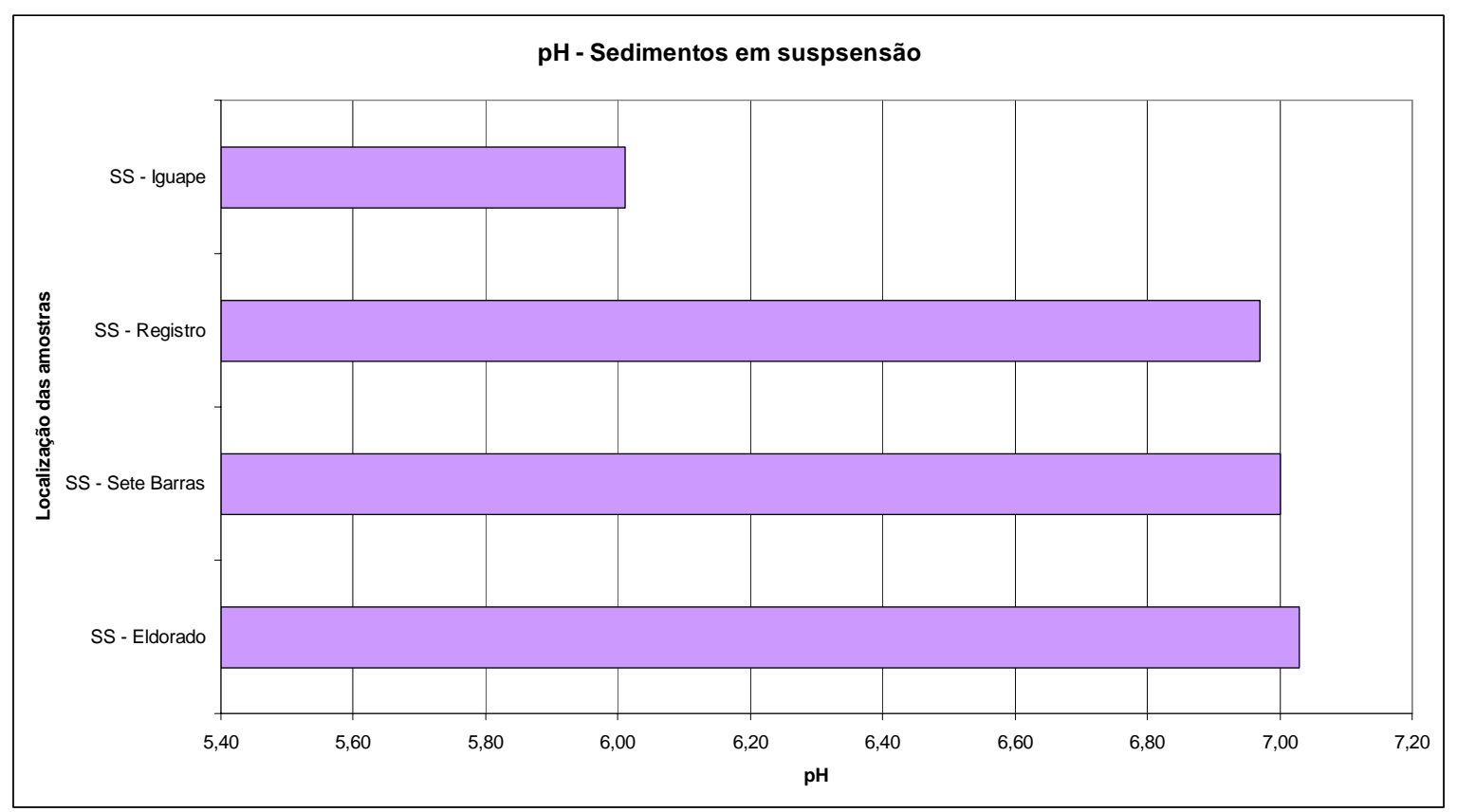

Gráfico 27 - Valores de pH obtidos nas amostras de sedimentos em suspensão

Nos sedimentos em suspensão, além do $\mathrm{pH}$ também foram obtidos valores do potencial de oxido-redução (Eh), sendo o valor médio deste parâmetro de 237,50 mV, o que caracteriza este material como oxidante. A amostra com valor mais elevado de Eh, portanto mais oxidante, está localizada em Eldorado, por outro lado, o menor valor de Eh obtido encontra-se no sedimento localizado em Iguape (Gráfico 28). 


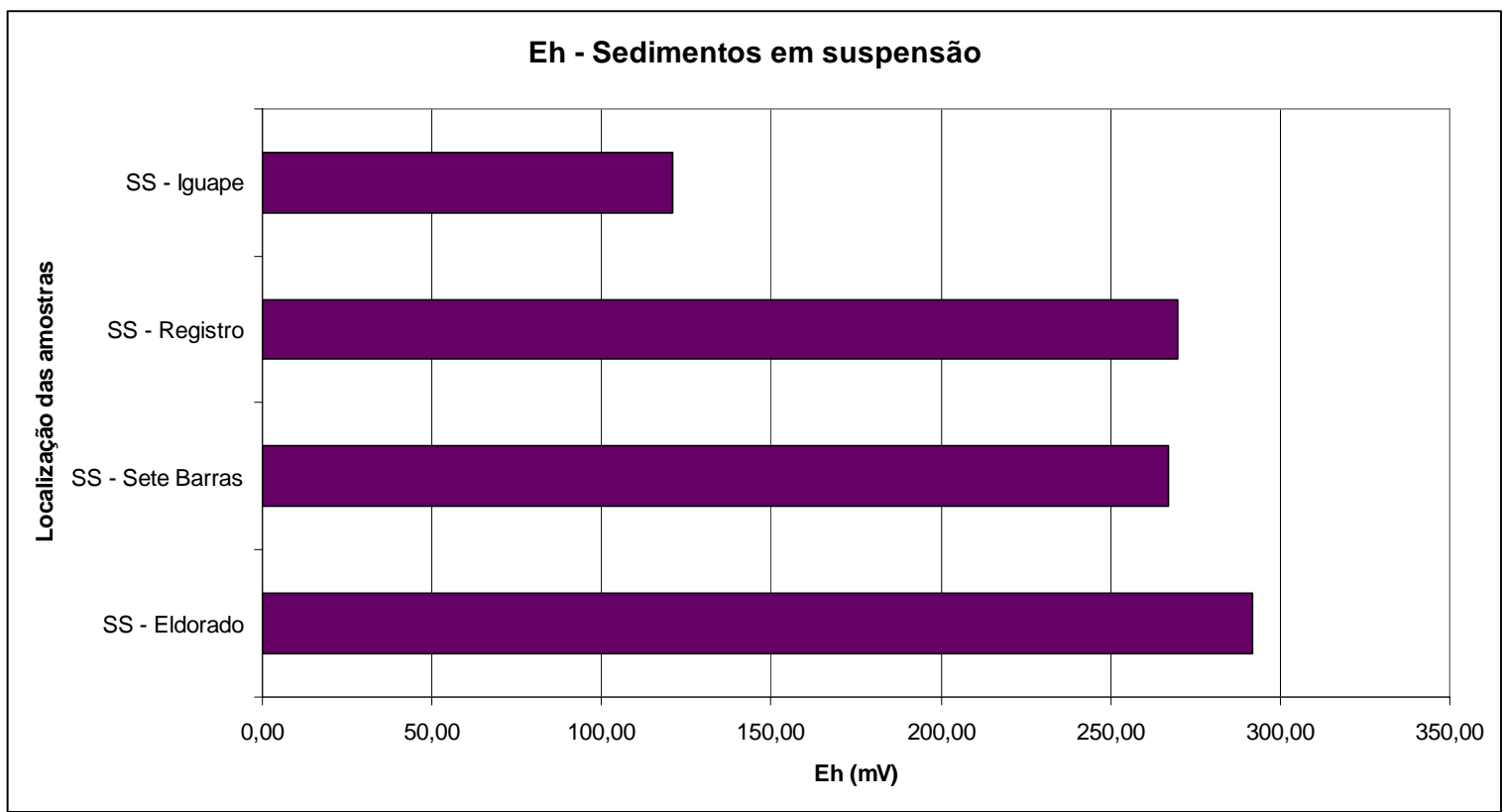

Gráfico 28 - Valores de Eh (mV) obtidos nas amostras de sedimentos em suspensão

Resumidamente, os valores de $\mathrm{pH}$ e Eh determinados para os sedimentos em suspensão coletados em Eldorado, Sete Barras e Registro, são bem similares, como observado nos gráficos 27 e 28 . O sedimento amostrado em Iguape exibiu valores de $\mathrm{pH}$ e Eh distintos das outras três amostras, sendo que estes parâmetros físico-químicos são inferiores aos obtidos nos outros pontos de coleta.

Estes sedimentos são compostos em média por: 67,15 \pm 5,82 de $\mathrm{SiO}_{2}, 14,62 \% \pm$ 2,68 de $\mathrm{Al}_{2} \mathrm{O}_{3}, 5,23 \pm 1,49$ de $\mathrm{Fe}_{2} \mathrm{O}_{3}$ e 3,74\% $\pm 0,75$ de $\mathrm{K}_{2} \mathrm{O}$, dados estes obtidos nas análises químicas por FRX (Tabela 19). Os teores detectados para $\mathrm{MnO}, \mathrm{MgO}, \mathrm{CaO}, \mathrm{Na}_{2} \mathrm{O}$, $\mathrm{TiO}_{2}$ e $\mathrm{P}_{2} \mathrm{O}_{5}$, estão abaixo de $1 \%$, como observado na tabela 19.

Tabela 19 - Análise química total por FRX - sedimento em suspensão - \% de óxidos

\begin{tabular}{ccccccccccccc}
\hline Amostras & $\mathrm{SiO}_{2}$ & $\mathbf{A}_{2} \mathrm{O}_{3}$ & $\mathrm{MnO}$ & $\mathbf{M g O}$ & $\mathrm{CaO}$ & $\mathrm{Na}_{2} \mathrm{O}$ & $\mathrm{K}_{2} \mathrm{O}$ & $\mathrm{TiO}_{2}$ & $\mathrm{P}_{2} \mathrm{O}_{5}$ & $\mathrm{Fe}_{2} \mathrm{O}_{3}$ & PF & Fechamento \\
\hline \hline SS - Eldorado & 72,03 & 12,12 & 0,09 & 1,16 & 1,06 & 1,29 & 3,63 & 0,82 & 0,08 & 4,91 & $\mathbf{2 , 9 3}$ & $\mathbf{1 0 0 , 1 2}$ \\
SS - Sete Barras & 70,88 & 12,60 & 0,16 & 0,97 & 0,89 & 1,24 & 3,80 & 0,74 & 0,11 & 5,10 & $\mathbf{3 , 6 9}$ & $\mathbf{1 0 0 , 1 7}$ \\
SS - Registro & 66,51 & 17,59 & 0,12 & 0,46 & 0,43 & 0,69 & 4,67 & 0,82 & 0,07 & 3,65 & $\mathbf{4 , 9 7}$ & $\mathbf{9 9 , 9 8}$ \\
SS - Iguape & 59,18 & 16,17 & 0,12 & 1,13 & 0,76 & 0,57 & 2,85 & 0,93 & 0,24 & 7,25 & $\mathbf{1 1 , 1 6}$ & $\mathbf{1 0 0 , 3 6}$ \\
\hline \hline Média & $\mathbf{6 7 , 1 5}$ & $\mathbf{1 4 , 6 2}$ & $\mathbf{0 , 1 2}$ & $\mathbf{0 , 9 3}$ & $\mathbf{0 , 7 8}$ & $\mathbf{0 , 9 5}$ & $\mathbf{3 , 7 4}$ & $\mathbf{0 , 8 3}$ & $\mathbf{0 , 1 2}$ & $\mathbf{5 , 2 3}$ & $\mathbf{5 , 6 9}$ & \\
\hline \hline Erro & $\mathbf{2 , 9 1}$ & $\mathbf{1 , 3 4}$ & $\mathbf{0 , 0 1}$ & $\mathbf{0 , 1 6}$ & $\mathbf{0 , 1 3}$ & $\mathbf{0 , 1 9}$ & $\mathbf{0 , 3 7}$ & $\mathbf{0 , 0 4}$ & $\mathbf{0 , 0 4}$ & $\mathbf{0 , 7 5}$ & $\mathbf{1 , 8 7}$ & \\
\hline \hline Desvio Padrão & $\mathbf{5 , 8 2}$ & $\mathbf{2 , 6 8}$ & $\mathbf{0 , 0 3}$ & $\mathbf{0 , 3 2}$ & $\mathbf{0 , 2 6}$ & $\mathbf{0 , 3 7}$ & $\mathbf{0 , 7 5}$ & $\mathbf{0 , 0 8}$ & $\mathbf{0 , 0 8}$ & $\mathbf{1 , 4 9}$ & $\mathbf{3 , 7 4}$ & \\
\hline
\end{tabular}

A média de perda ao fogo determinada para os sedimentos em suspensão foi de $5,69 \%$. O valor mais elevado de perda ao fogo foi obtido no sedimento coletado em Iguape $(11,16 \%)$ e o menor na amostra referente a Eldorado (2,93\%), como observado na tabela 19. 
Além dos elementos mencionados, também foram determinados teores de metais pesados e de $\mathrm{Ba}$. Estes sedimentos apresentaram a seguinte composição média para estes elementos: $70,50 \mathrm{mg} / \mathrm{kg}$ de $\mathrm{Pb}, 115,58 \mathrm{mg} / \mathrm{kg}$ de $\mathrm{Zn}, 28,33 \mathrm{mg} / \mathrm{kg}$ de $\mathrm{Cu}, 67,79 \mathrm{mg} / \mathrm{kg}$ de $\mathrm{Cr}$ e 1166,99 mg/kg de Ba (Tabela 20). Nesta mesma tabela, observa-se que os maiores teores de $\mathrm{Zn}$, Cu e Cr concentram-se na amostra localizada em Iguape, e que o maior teor de $\mathrm{Pb}$ encontra-se na amostra coletada em Eldorado.

Tabela 20 - Teores de Ba e metais pesados nos sedimentos em suspensão (mg/kg)

\begin{tabular}{cccccc}
\hline Amostras & $\begin{array}{c}\mathbf{P b} \\
\mathbf{m g} / \mathbf{k g}\end{array}$ & $\begin{array}{c}\mathbf{Z n} \\
\mathbf{m g} / \mathbf{k g}\end{array}$ & $\begin{array}{c}\mathbf{C u} \\
\mathbf{m g} / \mathbf{k g}\end{array}$ & $\begin{array}{c}\mathbf{C r} \\
\mathbf{m g} / \mathbf{k g}\end{array}$ & $\begin{array}{c}\mathbf{B a} \\
\mathbf{m g} / \mathbf{k g}\end{array}$ \\
\hline \hline SS - Eldorado & 99,66 & 133,00 & 31,33 & 65,00 & 1153,30 \\
SS - Sete Barras & 74,00 & 114,00 & 25,00 & 63,50 & 1185,00 \\
SS - Registro & 32,33 & 71,33 & 20,00 & 57,66 & 1516,66 \\
SS - Iguape & 76,00 & 144,00 & 37,00 & 85,00 & 813,00 \\
\hline \hline Média & $\mathbf{7 0 , 5 0}$ & $\mathbf{1 1 5 , 5 8}$ & $\mathbf{2 8 , 3 3}$ & $\mathbf{6 7 , 7 9}$ & $\mathbf{1 1 6 6 , 9 9}$ \\
\hline \hline
\end{tabular}

$\mathrm{Na}$ tabela 20, nota-se que o teor mais elevado de $\mathrm{Ba}$ foi detectado na amostra coletada em Registro e o menor no sedimento amostrado em Iguape. A tendência deste elemento é de aumento, de Eldorado até Registro, a partir de Registro ele exibiu outro comportamento químico, como foi verificado para os outros elementos químicos aqui analisados e para os metais pesados.

Com o intuito de verificar possíveis associações entre os diversos elementos analisados nestes sedimentos foi confeccionada matriz de correlação de Pearson (Tabela 21). Nesta matriz, nota-se elevada correlação, principalmente entre: pH-Eh, Cu-Cr, Zn-Cu, Fe-Cr, Fe-Cu, P-Cr, K-Ba, Ca-Pb, Mg-Zn e Mg-Pb, para tanto, levou-se em consideração o valor de 0,90 obtido nesta matriz de correlação e os elementos de interesse neste estudo.

Tabela 21 - Matriz de Correlação de Pearson para os parâmetros físico-químicos e elementos químicos nos sedimentos em suspensão

\begin{tabular}{|c|c|c|c|c|c|c|c|c|c|c|c|c|c|c|c|c|c|}
\hline & $p H$ & $E h$ & $\mathrm{Si}$ & $A l$ & $M n$ & $M g$ & $\mathrm{Ca}$ & $\mathrm{Na}$ & $K$ & $\mathrm{Ti}$ & $P$ & $\mathrm{Fe}$ & $P b$ & $Z n$ & $\mathrm{Cu}$ & $\mathrm{Cr}$ & $\mathrm{Ba}$ \\
\hline$\overline{\mathrm{pH}}$ & 1 & & & & & & & & & & & & & & & & \\
\hline Eh & 0,99 & 1,00 & & & & & & & & & & & & & & & \\
\hline $\mathrm{Si}$ & 0,93 & 0,94 & 1,00 & & & & & & & & & & & & & & \\
\hline $\mathrm{Al}$ & $-0,43$ & $-0,44$ & $-0,73$ & 1,00 & & & & & & & & & & & & & \\
\hline $\mathrm{Mn}$ & 0,09 & $-0,01$ & 0,11 & $-0,18$ & 1,00 & & & & & & & & & & & & \\
\hline $\mathrm{Mg}$ & $-0,37$ & $-0,33$ & $-0,01$ & $-0,66$ & $-0,09$ & 1,00 & & & & & & & & & & & \\
\hline $\mathrm{Ca}$ & 0,10 & 0,15 & 0,46 & $-0,93$ & $-0,03$ & 0,89 & 1,00 & & & & & & & & & & \\
\hline $\mathrm{Na}$ & 0,71 & 0,72 & 0,92 & $-0,94$ & 0,18 & 0,37 & 0,76 & 1,00 & & & & & & & & & \\
\hline $\mathrm{K}$ & 0,76 & 0,74 & 0,47 & 0,26 & 0,04 & $-0,88$ & $-0,56$ & 0,09 & 1,00 & & & & & & & & \\
\hline $\mathrm{Ti}$ & $-0,88$ & $-0,83$ & $-0,87$ & 0,54 & $-0,55$ & 0,25 & $-0,18$ & $-0,75$ & $-0,58$ & 1,00 & & & & & & & \\
\hline $\mathrm{P}$ & $-0,98$ & $-0,98$ & $-0,85$ & 0,26 & 0,06 & 0,50 & 0,04 & $-0,57$ & $-0,85$ & 0,77 & 1,00 & & & & & & \\
\hline $\mathrm{Fe}$ & $-0,88$ & $-0,88$ & $-0,66$ & $-0,04$ & 0,05 & 0,74 & 0,35 & $-0,30$ & $-0,97$ & 0,67 & 0,95 & 1,00 & & & & & \\
\hline $\mathrm{Pb}$ & $-0,02$ & 0,04 & 0,33 & $-0,82$ & $-0,25$ & 0,92 & 0,97 & 0,63 & $-0,63$ & 0,03 & 0,13 & 0,42 & 1,00 & & & & \\
\hline $\mathrm{Zn}$ & $-0,55$ & $-0,51$ & $-0,21$ & $-0,50$ & $-0,12$ & 0,98 & 0,77 & 0,18 & $-0,96$ & 0,42 & 0,66 & 0,85 & 0,83 & 1,00 & & & \\
\hline $\mathrm{Cu}$ & $-0,75$ & $-0,70$ & $-0,48$ & $-0,20$ & $-0,30$ & 0,86 & 0,55 & $-0,13$ & $-0,96$ & 0,70 & 0,79 & 0,91 & 0,67 & 0,94 & 1,00 & & \\
\hline $\mathrm{Cr}$ & $-0,95$ & $-0,93$ & $-0,77$ & 0,13 & $-0,09$ & 0,64 & 0,21 & $-0,46$ & $-0,93$ & 0,80 & 0,97 & 0,98 & 0,32 & 0,78 & 0,91 & 1,00 & \\
\hline $\mathrm{Ba}$ & 0,79 & 0,77 & 0,52 & 0,21 & 0,00 & $-0,85$ & $-0,51$ & 0,14 & 1,00 & $-0,60$ & $-0,88$ & $-0,98$ & $-0,58$ & $-0,94$ & $-0,95$ & $-0,94$ & 1,00 \\
\hline
\end{tabular}


Entre os elementos de interesse verifica-se existir forte correlação entre: $\mathrm{Zn}-\mathrm{Cu}$, Cu$\mathrm{Cr}$ e $\mathrm{Pb}-\mathrm{Ca}$. Como anteriormente mencionado estes dados servem apenas como indicativo de possíveis associações entre os diversos elementos aqui analisados. Desta forma, são exibidos a seguir os resultados obtidos para os elementos de interesse em grupos assim delimitados: Ca-Mg-Fe, Pb-Zn, Cr-Cu e Cr-Ba.

\section{$\underline{\mathrm{Ca}, \mathrm{Mge} \mathrm{Fe}}$}

Os teores médios detectados nestes sedimentos para estes elementos foram respectivamente: $\mathrm{CaO}$ de 0,78\%, $\mathrm{MgO}$ de 0,93\% e $\mathrm{Fe}_{2} \mathrm{O}_{3}$ de 5,23\%. Conforme gráfico 29, verifica-se que as curvas de concentrações químicas do $\mathrm{Ca}$ e $\mathrm{Mg}$ são similares. O Fe exibe a mesma tendência de concentração química que o $\mathrm{Ca}$ e $\mathrm{Mg}$, exceto para a amostra coleta em Sete Barras (Gráfico 29).

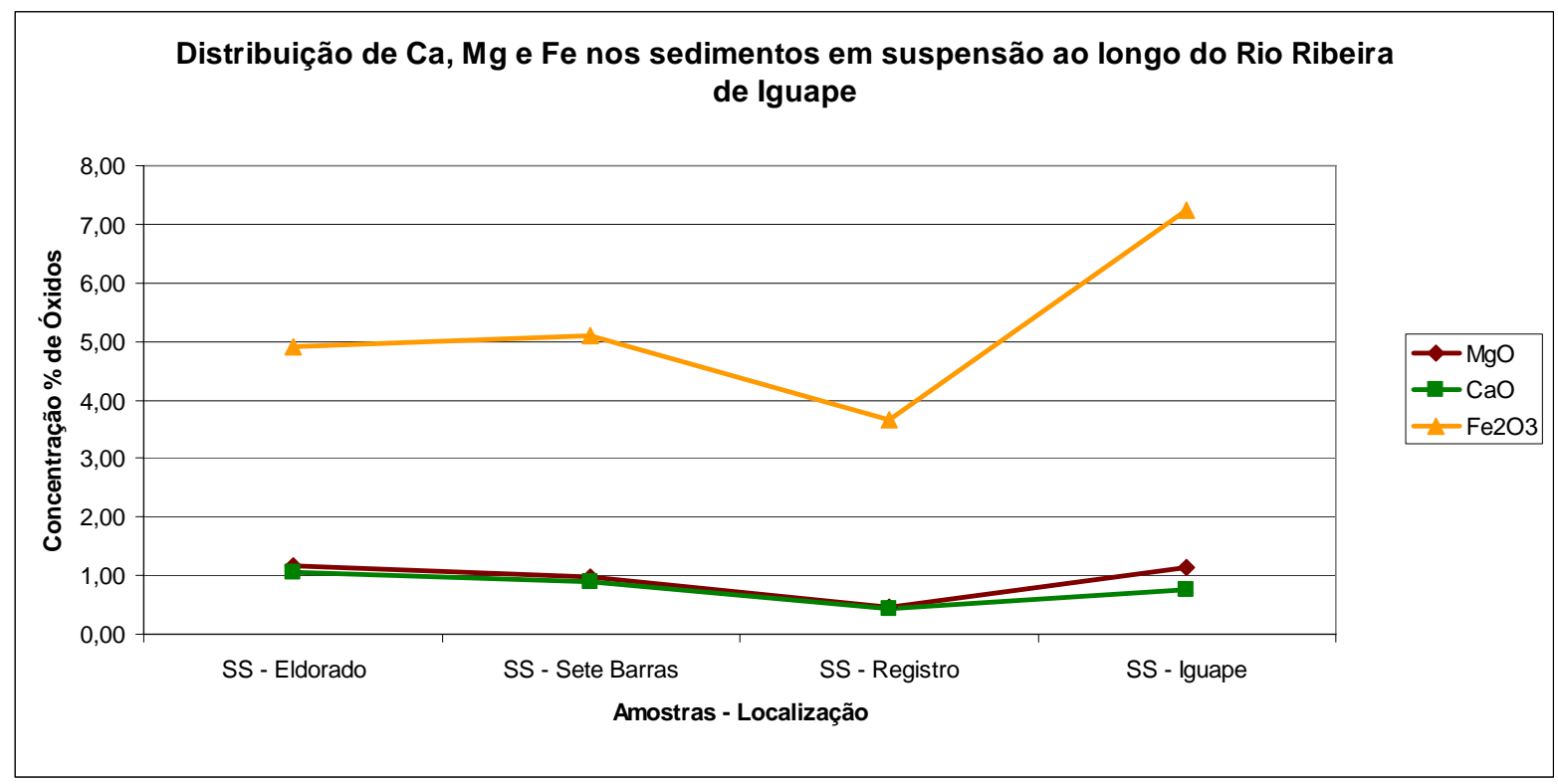

Gráfico 29 - Distribuição de Ca, Mg e Fe nos sedimentos em suspensão

De modo geral, observa-se neste gráfico, que existe uma tendência de decréscimo nos teores de $\mathrm{Ca}, \mathrm{Mg}$ e Fe de Eldorado até Registro. Em Iguape o comportamento modificase indicando acréscimo de teores dos elementos analisados.

$\underline{\mathrm{Pb} \text { e } \mathrm{Zn}}$

Os teores médios de $\mathrm{Pb}$ e $\mathrm{Zn}$ foram de $70,50 \mathrm{mg} / \mathrm{kg}$ e de 115,58 mg/kg, respectivamente. Estes dois metais pesados apresentam mesma tendência de concentração química, neste tipo de sedimento, como observado no gráfico 30. Neste mesmo gráfico, nota-se que $\mathrm{Pb}$ e $\mathrm{Zn}$ exibem mesma distribuição química anteriormente comentada para Ca$\mathrm{Mg}-\mathrm{Fe}$, ou seja, tendência de decréscimo de Eldorado até Registro e acréscimo em Iguape. 


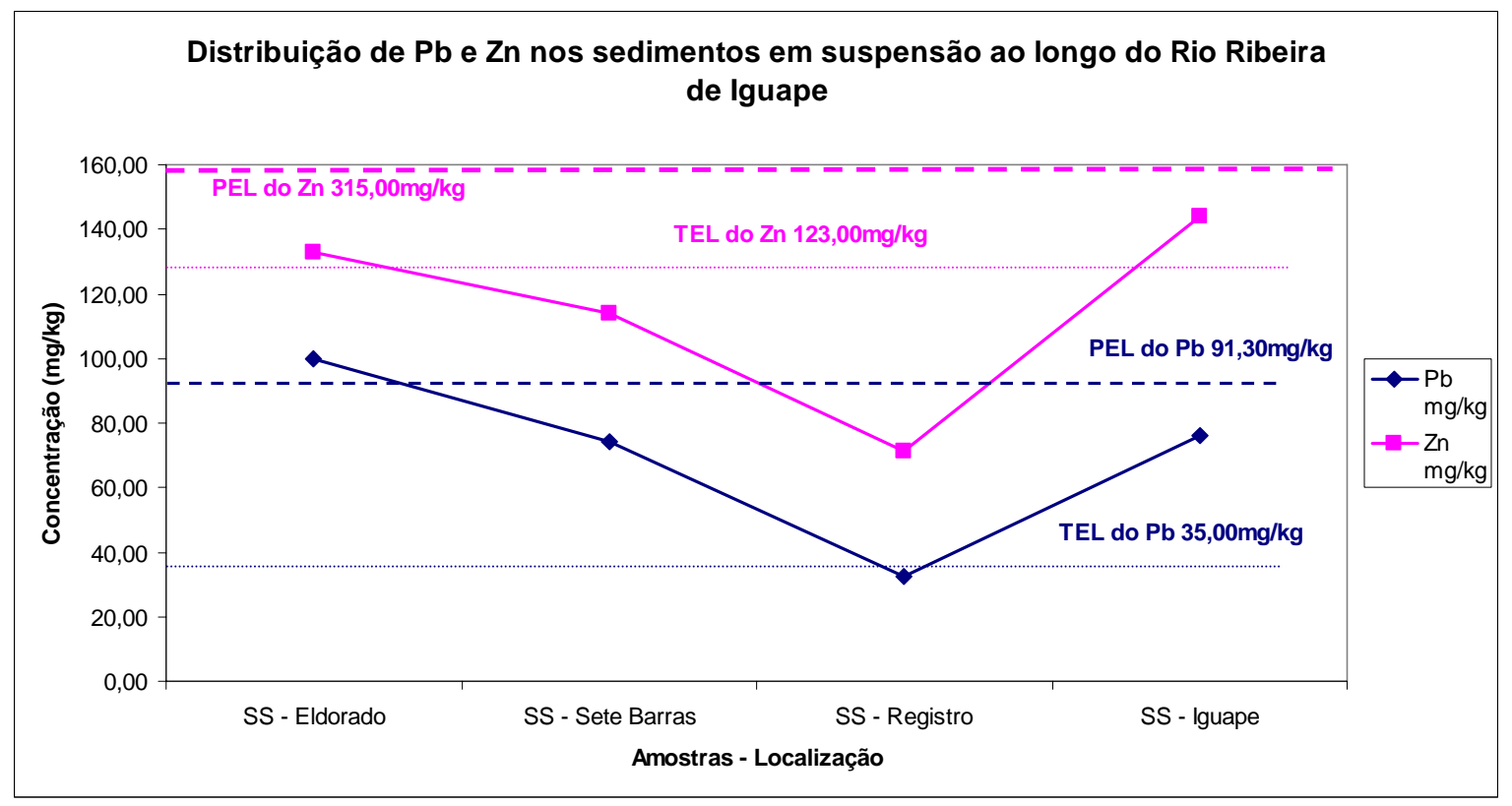

Gráfico 30 - Distribuição de Pb e Zn nos sedimentos em suspensão

Como indicativo da possível contaminação destes metais pesados foi empregado o valor de referência PEL/TEL do CCME (1999), deve ser salientado, no entanto, que os valores de referência aplicados neste modelo de padrão foram obtidos em sedimentos de corrente e na ausência de um padrão para sedimentos em suspensão, optou-se por utilizar o mesmo com restrição pela não similaridade. $\mathrm{O} \mathrm{Pb}$ só ultrapassou o valor de referência PEL para a amostra coletada em Eldorado, excedendo o valor TEL para os sedimentos coletados em Eldorado, Sete Barras e Iguape, como indicado no gráfico 30.

Em nenhum dos sedimentos em suspensão investigados, o Zn excedeu o valor de referencia PEL, ultrapassando a referência TEL para as amostras de Eldorado e Iguape (Gráfico 30).

\section{$\underline{\mathrm{Cr} \text { e Cu}}$}

O teor médio de $\mathrm{Cr}$ obtido foi de $67,79 \mathrm{mg} / \mathrm{kg}$ e o de $\mathrm{Cu}$ de $28,33 \mathrm{mg} / \mathrm{kg}$, nos sedimentos em suspensão. A curva de concentração química para estes dois metais pesados é semelhante, como observado no gráfico. 


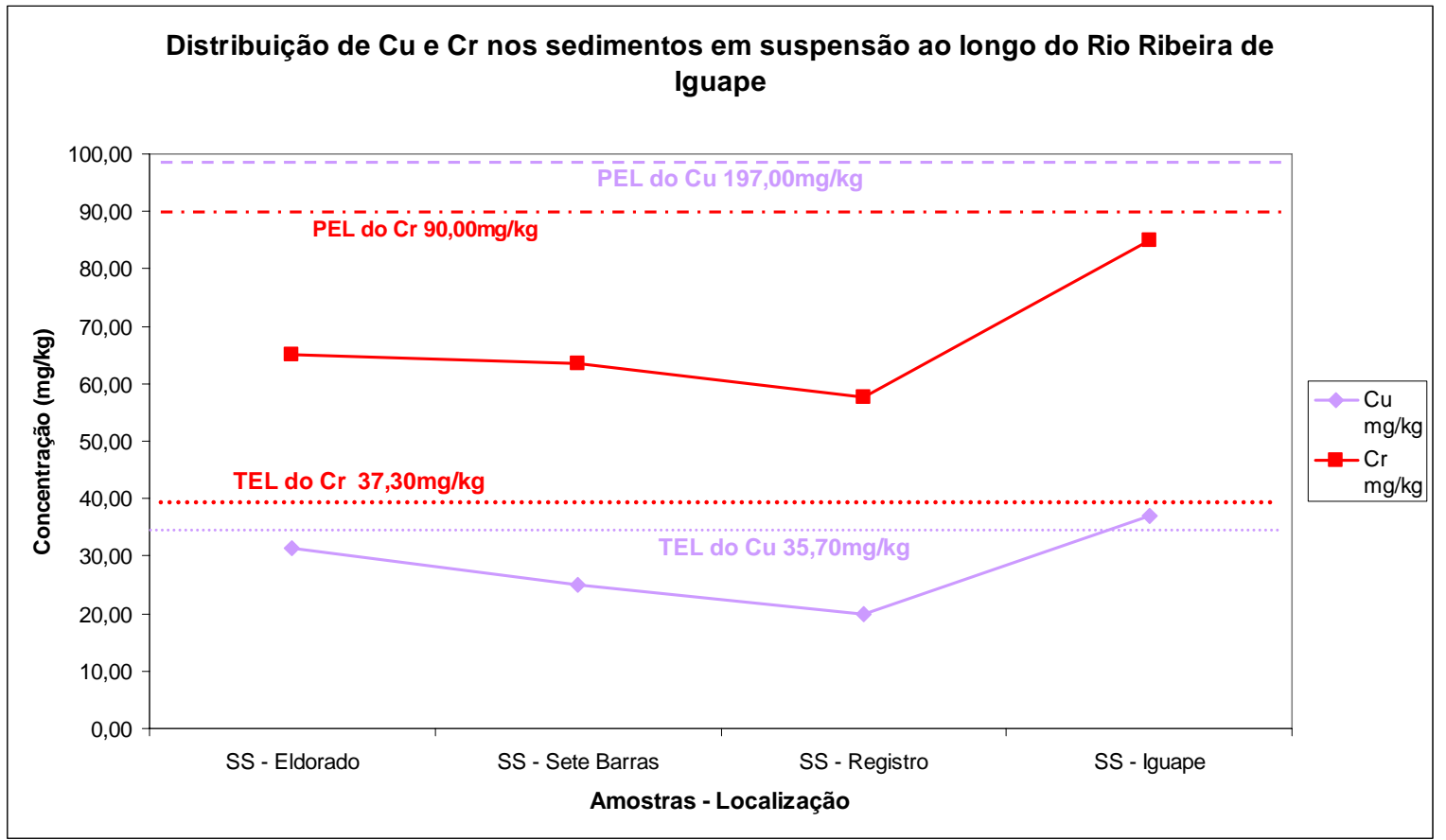

Gráfico 31 - Distribuição de Cu e Cr nos sedimentos em suspensão

Apenas a amostra coletada em Iguape exibiu teor acima do valor de referência TEL para o $\mathrm{Cu}$, o restante está abaixo deste valor de referência (Gráfico 31). Neste mesmo gráfico, observa-se que todas as amostras estão acima do valor de referência TEL para o $\mathrm{Cr}$ e abaixo do valor de referência PEL.

Considerações sobre os resultados obtidos

É possível distinguir-se duas tendências de concentrações químicas nos sedimentos em suspensão com relação aos metais pesados neles contidos, uma é na amostra coletada em Iguape cujos teores de $\mathrm{Cu}, \mathrm{Cr}$ e $\mathrm{Zn}$ são mais elevados que nos sedimentos dos outros pontos de coleta, e outra é a maior concentração de $\mathrm{Pb}$ no sedimento amostrado em Eldorado.

As amostras de sedimento em suspensão coletadas de Eldorado até Registro exibem teores similares para os elementos químicos e comportamento físico-químico semelhantes. Em Iporanga estes sedimentos já estão recebendo influência marinha, e com isso as condições de pH, Eh e concentração dos elementos são dependentes da interação água fluvial e marinha, divergindo, por tanto dos resultados obtidos nos outros três sedimentos em suspensão aqui apresentados.

Basicamente, os metais pesados de estudo estão abaixo do padrão PEL, exceto o $\mathrm{Pb}$ no sedimento coletado em Eldorado mesmo considerando uma comparação com o 
parâmetro PEL/TEL não muito adequada para este tipo de material como comentado anteriormente.

\subsubsection{Porção magnética do sedimento em suspensão}

Com o propósito de se detectar os resíduos da metalurgia nos sedimentos em suspensão, optou-se por analisar separadamente a porção magnética (cerca de $7 \%$ da amostra total em peso) e não magnética, deste sedimento. Para tanto, estas duas frações foram separadas através do emprego de um imã e foram analisadas em FRX. Em virtude da pequena quantidade de amostra magnética, só foi possível executar tal procedimento com os sedimentos em suspensão coletados em Eldorado. Cabe ressaltar que este sedimento não é o mesmo que foi empregado para análise total (exibido no capítulo anterior), este foi coletado em outro período, devido à quantidade insuficiente de amostra.

A porção magnética do sedimento em suspensão apresentou a seguinte composição química: $48,90 \%$ de $\mathrm{Fe}_{2} \mathrm{O}_{3}, 22,50 \%$ de $\mathrm{SiO}_{2}, 13,60 \%$ de $\mathrm{TiO}_{2}, 5,29 \%$ de $\mathrm{CaO}, 4,55 \%$ de $\mathrm{Al}_{2} \mathrm{O}_{3}$ e 2,54\% de $\mathrm{MgO}$, estando os outros elementos abaixo de 1\% (Tabela 22). Nesta mesma tabela, nota-se que a porção não magnética é composta por: $71,70 \%$ de $\mathrm{SiO}_{2}$, 9,51\% de $\mathrm{Al}_{2} \mathrm{O}_{3}, 6,20 \%$ de $\mathrm{Fe}_{2} \mathrm{O}_{3}, 3,86 \%$ de $\mathrm{CaO}, 3,22 \%$ de $\mathrm{K} 2 \mathrm{O}, 1,58 \%$ de $\mathrm{MgO}$ e 1,54\% de $\mathrm{Na}_{2} \mathrm{O}$, os outros elementos são inferiores a $1 \%$.

Tabela 22 - Comparação dos teores detectados na porção magnética e não magnética do sedimento em suspensão, coletado em Eldoardo - FRX - \% de Óxidos

\begin{tabular}{|c|c|c|c|c|c|c|c|c|c|c|c|c|c|c|c|c|c|}
\hline Amostras & $\begin{array}{c}\mathrm{SiO}_{2} \\
\%\end{array}$ & $\begin{array}{c}\mathrm{A}_{2} \mathrm{O}_{3} \\
\%\end{array}$ & $\begin{array}{c}\text { Mno } \\
\%\end{array}$ & $\begin{array}{c}\text { MgO } \\
\%\end{array}$ & $\begin{array}{c}\mathrm{CaO} \\
\%\end{array}$ & $\begin{array}{c}\mathrm{Na}_{2} \mathrm{O} \\
\%\end{array}$ & $\begin{array}{c}\mathrm{K}_{2} \mathrm{O} \\
\%\end{array}$ & $\begin{array}{c}\mathrm{TiO}_{2} \\
\%\end{array}$ & $\begin{array}{c}\mathrm{P}_{2} \mathrm{O}_{5} \\
\%\end{array}$ & $\begin{array}{c}\mathrm{Fe}_{2} \mathrm{O}_{3} \\
\%\end{array}$ & $\begin{array}{c}\mathrm{SO}_{3} \\
\%\end{array}$ & $\begin{array}{c}\mathrm{Cr}_{2} \mathrm{O}_{3} \\
\%\end{array}$ & $\begin{array}{c}\mathrm{CuO} \\
\%\end{array}$ & $\begin{array}{c}\text { Zno } \\
\%\end{array}$ & $\begin{array}{c}\mathrm{BaO} \\
\%\end{array}$ & $\begin{array}{c}\mathrm{PbO} \\
\%\end{array}$ & $\begin{array}{c}\text { Fechamento } \\
\%\end{array}$ \\
\hline SS - Total & 68,46 & 9,18 & 0,17 & 1,64 & 3,95 & 1,54 & 3,06 & 2,37 & 0,20 & 9,01 & 0,04 & 0,09 & 0,01 & 0,07 & 0,17 & 0,04 & 100,01 \\
\hline SS - Não Magnético & 71,70 & 9,51 & 0,13 & 1,58 & 3,86 & 1,54 & 3,22 & 1,58 & 0,20 & 6,20 & 0,04 & 0,09 & 0,01 & 0,04 & 0,17 & 0,03 & 99,90 \\
\hline SS - Magnético & 22,50 & 4,55 & 0,73 & 2,54 & 5,29 & $\ll$ & 0,72 & 13,60 & 0,17 & 48,90 & 0,09 & 0,10 & 0,02 & 0,42 & $\ll$ & 0,20 & 99,83 \\
\hline
\end{tabular}

Para melhor visualizar a diferença composicional das frações magnética e não magnética foram confeccionados gráficos de colunas para os elementos maiores (Gráfico 32) e para os metais pesados (Gráfico 33).

No gráfico 32, observa-se que os teores de $\mathrm{Fe}, \mathrm{Ti}, \mathrm{Ca}, \mathrm{Mg}$ e $\mathrm{Mn}$ são maiores na porção magnética do sedimento em suspensão do que na porção não magnética. Os teores de Fe e Ti detectados na porção magnética são aproximadamente 8 vezes maiores que os valores detectados na porção não magnética (Tabela 22). O teor de Si e Al encontrados na porção não magnética são aproximadamente 2 vezes mais elevados que os da fração magnética (Tabela 22). Lembrado que os valores detectados na porção magnética são referentes apenas a $7 \%$ do peso total da amostra. 


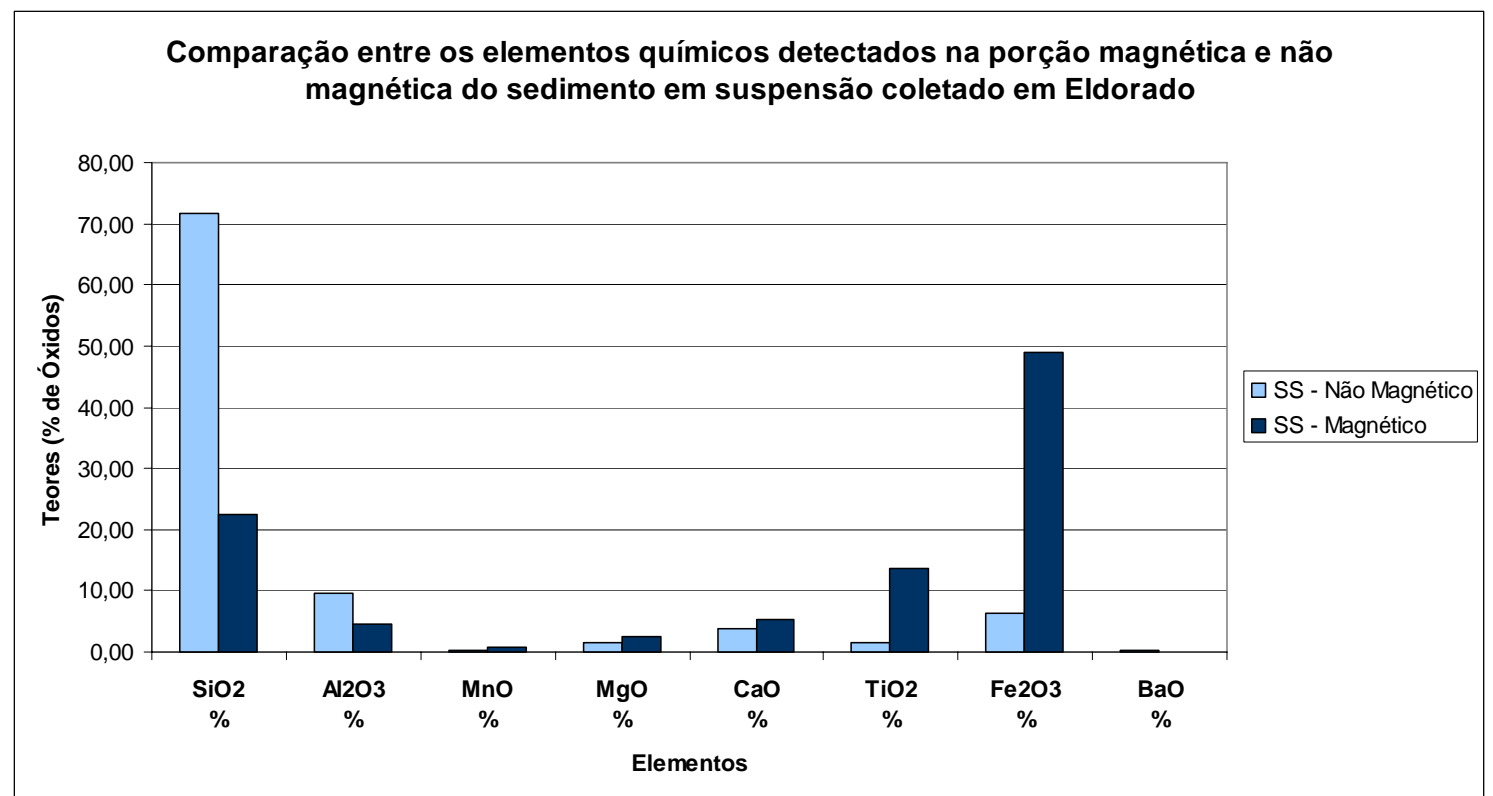

Gráfico 32 - Comparação entre os elementos químicos detectados na porção magnética e não magnética do sedimento em suspensão coletado em Eldorado

Nas duas porções analisadas foram detectados metais pesados, sendo os teores destes metais mais elevados na porção magnética do sedimento, como exibe o gráfico 33. Dos metais pesados investigados, o $\mathrm{Pb}$ e $\mathrm{Zn}$ foram os que exibiram maiores diferenças nos teores detectados nestas duas porções do sedimento em suspensão (Gráfico 33). A diferença do teor de $\mathrm{Zn}$ detectado na porção magnética foi de até 10 vezes o valor encontrado na porção não magnética (Tabela 22). O teor de $\mathrm{Pb}$ encontrado na porção magnética superou em aproximadamente 6,5 vezes o da porção não magnética (Tabela 22).

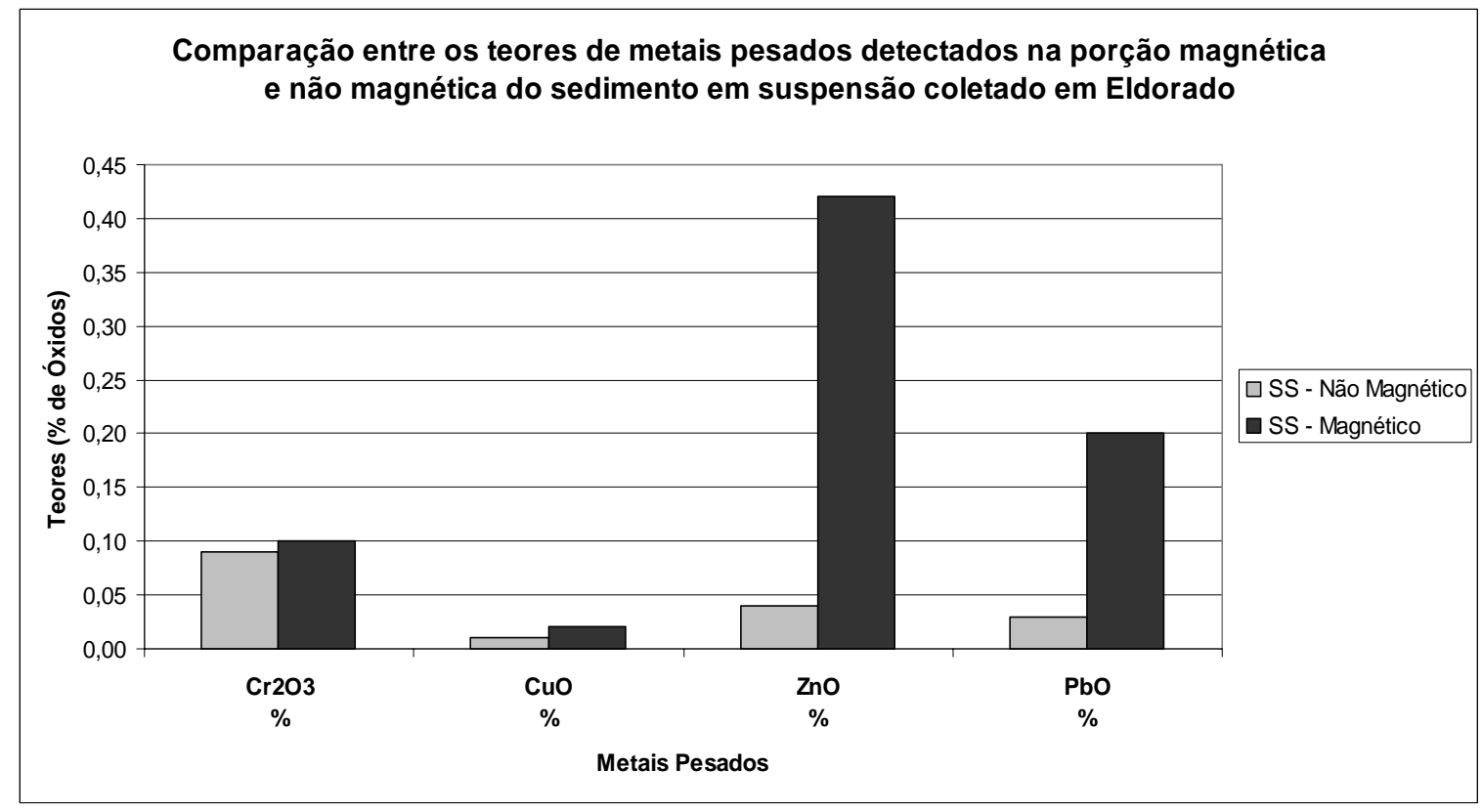


Gráfico 33 - Comparação entre os metais pesados detectados na porção magnética e não magnética do sedimento em suspensão coletado em Eldorado

Os teores de metais pesados, quando convertidos para $\mathrm{mg} / \mathrm{kg}$ apresentam-se elevados, principalmente para a fração magnética deste sedimento, como indicado na tabela 23. Estes teores foram comparados com os valores de referência PEL/TEL, como indicativo de possível contaminação, tendo certa restrição quanto ao uso deste padrão em face deste ser empregado para sedimentos não similares aos aqui investigados. Mesmo assim, tal padrão foi empregado em decorrência da ausência de um valor de referência para este tipo de sedimento, como já comentado.

Observa-se na tabela 23 que o $\mathrm{Cr}$, Zn e Pb detectados na porção magnética e não magnética dos sedimentos em suspensão ultrapassam os valores de referência PEL (intervenção) e TEL (alerta), indicando estarem estes sedimentos sob condição de constante monitoramento e controle. Nesta mesma tabela, verifica-se que o $\mathrm{Cu}$, para os dois materiais analisados, só ultrapassou o valor de referência TEL, considerado de intervenção.

Tabela 23 - Teores de metais pesados em mg/kg nas porções magnéticas e não magnéticas do sedimento em suspensão de Eldorado, comparados com valores de referência PEL/TEL do CCME (1999)

\begin{tabular}{ccccc}
\hline Amostras & $\begin{array}{c}\mathrm{Cr} \\
\mathbf{m g} / \mathbf{k g}\end{array}$ & $\begin{array}{c}\mathrm{Cu} \\
\mathbf{m g} / \mathbf{k g}\end{array}$ & $\begin{array}{c}\mathrm{Zn} \\
\mathbf{m g} / \mathbf{k g}\end{array}$ & $\begin{array}{c}\mathbf{P b} \\
\mathbf{m g} / \mathbf{k g}\end{array}$ \\
\hline \hline SS - Não Magnético & 615,78 & 79,89 & 321,36 & 259,86 \\
SS - Magnético & 684,20 & 159,78 & 3374,28 & 1732,40 \\
\hline PEL & $\mathbf{9 0 , 0 0}$ & $\mathbf{1 9 7 , 0 0}$ & $\mathbf{3 1 5 , 0 0}$ & $\mathbf{9 1 , 3 0}$ \\
\hline TEL & $\mathbf{3 7 , 3 0}$ & $\mathbf{3 5 , 7 0}$ & $\mathbf{1 2 3 , 0 0}$ & $\mathbf{3 5 , 0 0}$ \\
\hline
\end{tabular}

O teor de $\mathrm{Cr}$, tanto na porção magnética como na não magnética, excedeu em aproximadamente 7 vezes o valor de referência PEL nesta forma de comparação (Tabela 23). Nesta mesma tabela, nota-se que na porção magnética do sedimento em suspensão, o Zn ultrapassou em até 10 vezes e o $\mathrm{Pb}$ em aproximadamente 19 vezes, o valor de referência PEL para cada um destes metais pesados.

A porção magnética do sedimento em suspensão, também foi analisada em MEV/EDS. Nesta análise foram detectadas esferas (Figuras 34 e 35) que no EDS mostraram ser compostas essencialmente por Fe. Em função de sua morfologia e constituição, tais esferas devem ser resultado dos processos de fundição e associadas diretamente com as escórias de fundição, a qual foi lançada no rio Ribeira no período de produção de lingotes de chumbo na Mina de Panelas. 


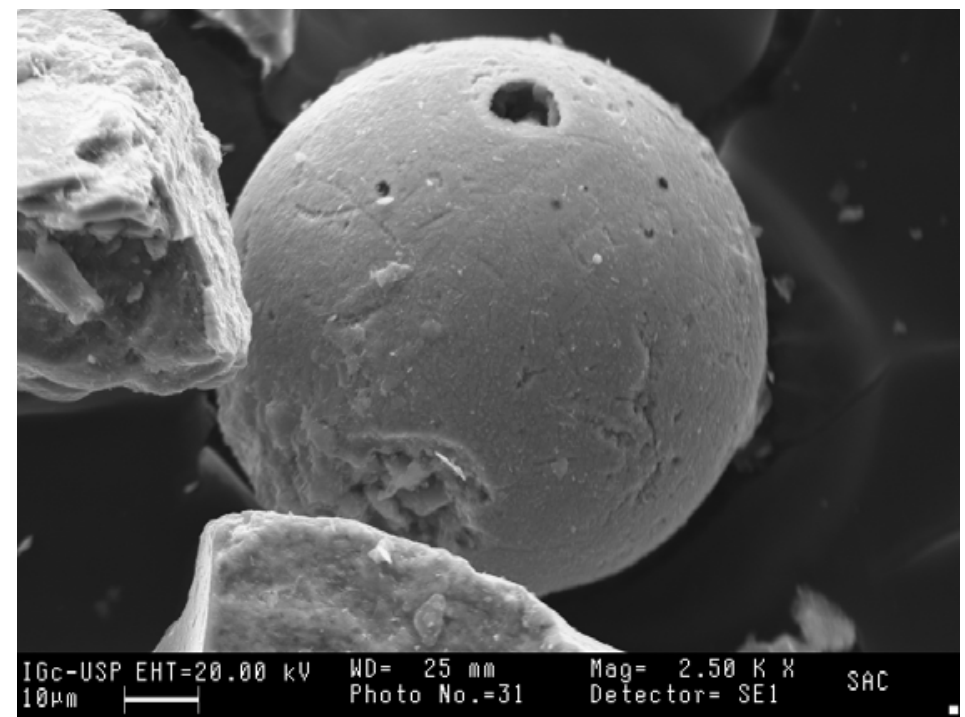

Figura 34 - Esfera de Fe detectada na parte magnética do sedimento em suspensão (imagem com elétrons retroespalhados em MEV)

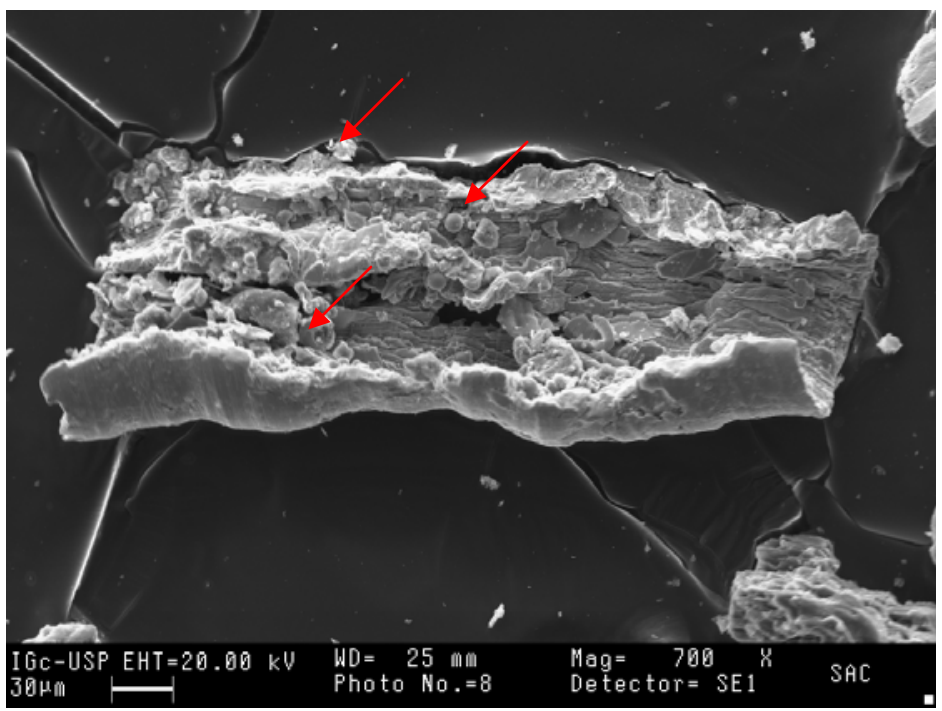

Figura 35 - Estrutura detectada na parte magnética do sedimento em suspensão com várias esferas de Fe (seta vermelha) em seu interior (imagem com elétrons retro-espalhados obtida em MEV)

No MEV/EDS identificou-se também ser a parte magnética dos sedimentos em suspensão composta por: magnetita (Figura 36), hematita e ilmenita, além de terem sido encontrados óxidos de Fe juntamente com porção argilosa (Figura 37). 


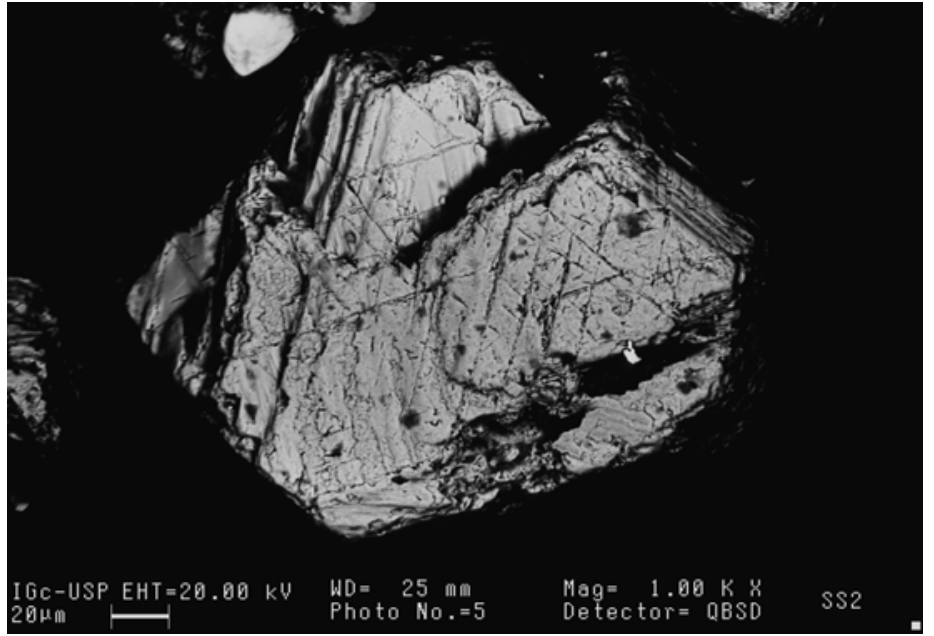

Figura 36 - Cristal de magnetita detectado na porção magnética do sedimento em suspensão (imagem com elétrons retro-espalhados obtida em MEV)

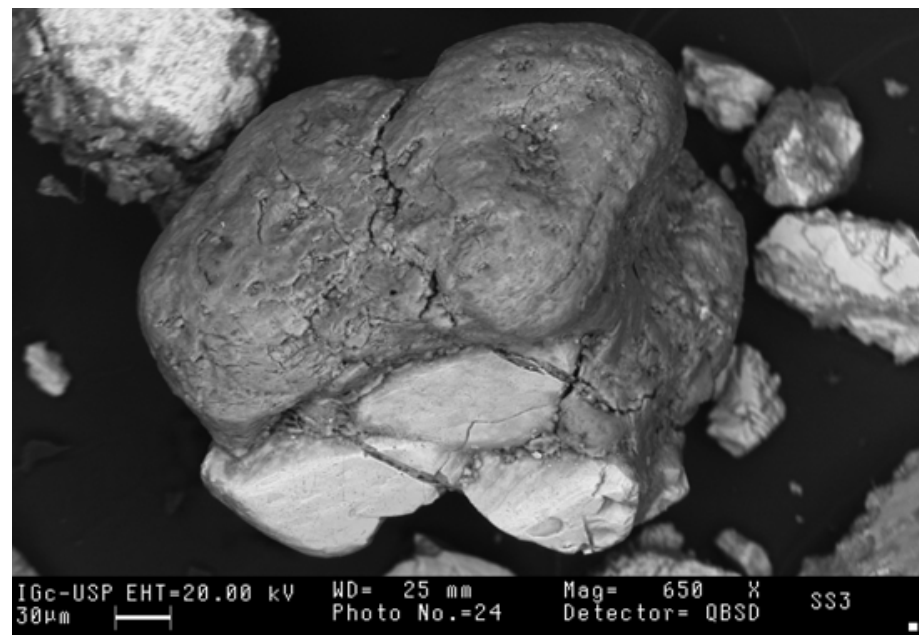

Figura 37 - Grão de argilo-mineral (parte escura da imagem) juntamente com hidróxido de Fe (parte brilhante da imagem). Imagem em MEV com elétrons retro-espalhados

Em vários pontos da porção magnética do sedimento em suspensão foram realizadas análises pontuais em EDS, que no geral, demonstraram a presença de $\mathrm{Fe}, \mathrm{Ti}$, $\mathrm{Mn}, \mathrm{Ca}, \mathrm{Zn}$ e Pb (Figura 38).

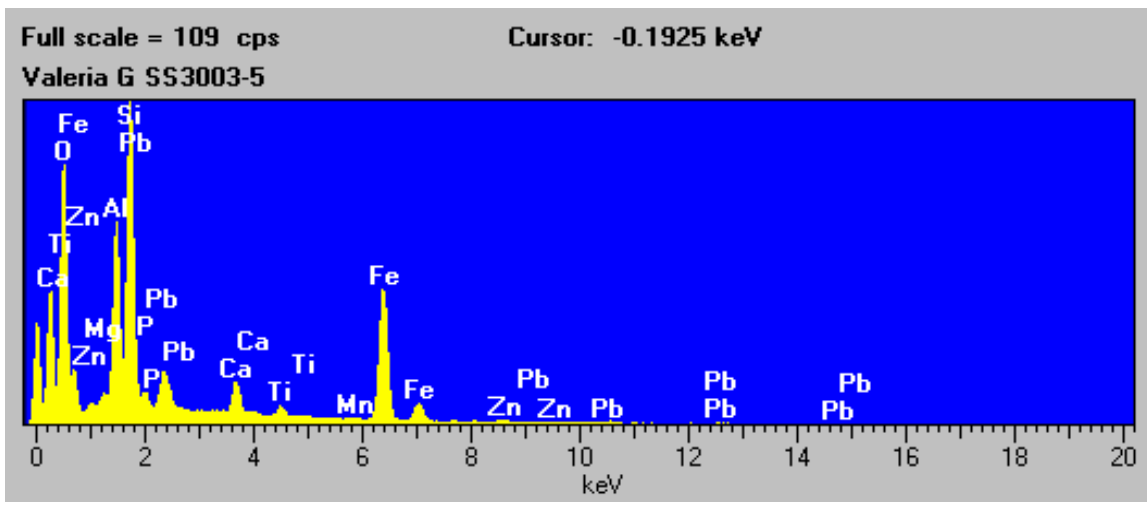

Figura 38 - EDS (representativo) de alguns grãos que compõem a parte magnética do sedimento em suspensão 
Preliminarmente, os resultados das análises químicas na porção magnética, bem como os dados obtidos em MEV/EDS, indicam fortemente a presença de resíduos da metalurgia juntamente com os sedimentos em suspensão.

\section{Considerações sobre os resultados obtidos}

As análises químicas juntamente com a investigação realizada em MEV/EDS, sinalizam para a provável presença do resíduo da metalurgia na porção magnética do sedimento em suspensão coletado em Eldorado. Tal fato é sustentado, principalmente pelos elevados teores de $\mathrm{Pb}, \mathrm{Zn}, \mathrm{Fe}, \mathrm{Ca}$ e $\mathrm{Mg}$ detectados nesta porção que são da mesma ordem de grandeza dos detectados no resíduo da metalurgia.

A imagem em MEV obtida nesta porção magnética dos sedimentos em suspensão (esferas), juntamente com o EDS deste material, também leva a supor a possível existência do resíduo da metalurgia neste sedimento.

\subsubsection{Sedimentos estuarinos}

Este tipo de sedimento foi coletado em um único ponto, ilha do Caranguejo no canal do Mar Pequeno nas proximidades de Iguape, em amostragem de 0,45 $\mathrm{m}$ de profundidade. Os resultados apresentados a seguir referem-se a três intervalos analisados neste segmento de $45 \mathrm{~cm}$ : 0-0,15 m, 0,15-0,30 m e 0,30-0,45 m.

O teor médio de matéria orgânica detectado neste sedimento foi de 2,97\%, apresentando modificações neste valor conforme a profundidade analisada. As amostras correspondentes às porções mediana (3,39\%) e basal $(3,30 \%)$ são mais enriquecidas em matéria orgânica do que a amostra superficial (2,22\%), neste segmento de $45 \mathrm{~cm}$.

Do ponto de vista granulométrico estes sedimentos são compostos principalmente pela fração areia (média de 55,33\%), seguidos pelas frações silte (média de 30,10\%) e argila (média de 14,67\%). O gráfico 34 exibe a distribuição gráfica destes conteúdos nas diferentes profundidades analisadas, evidenciando que nos intervalos de 0,15-0,30 m e 0,30-0,45 m os sedimentos são mais finos que nos primeiros 20 centímetros. 


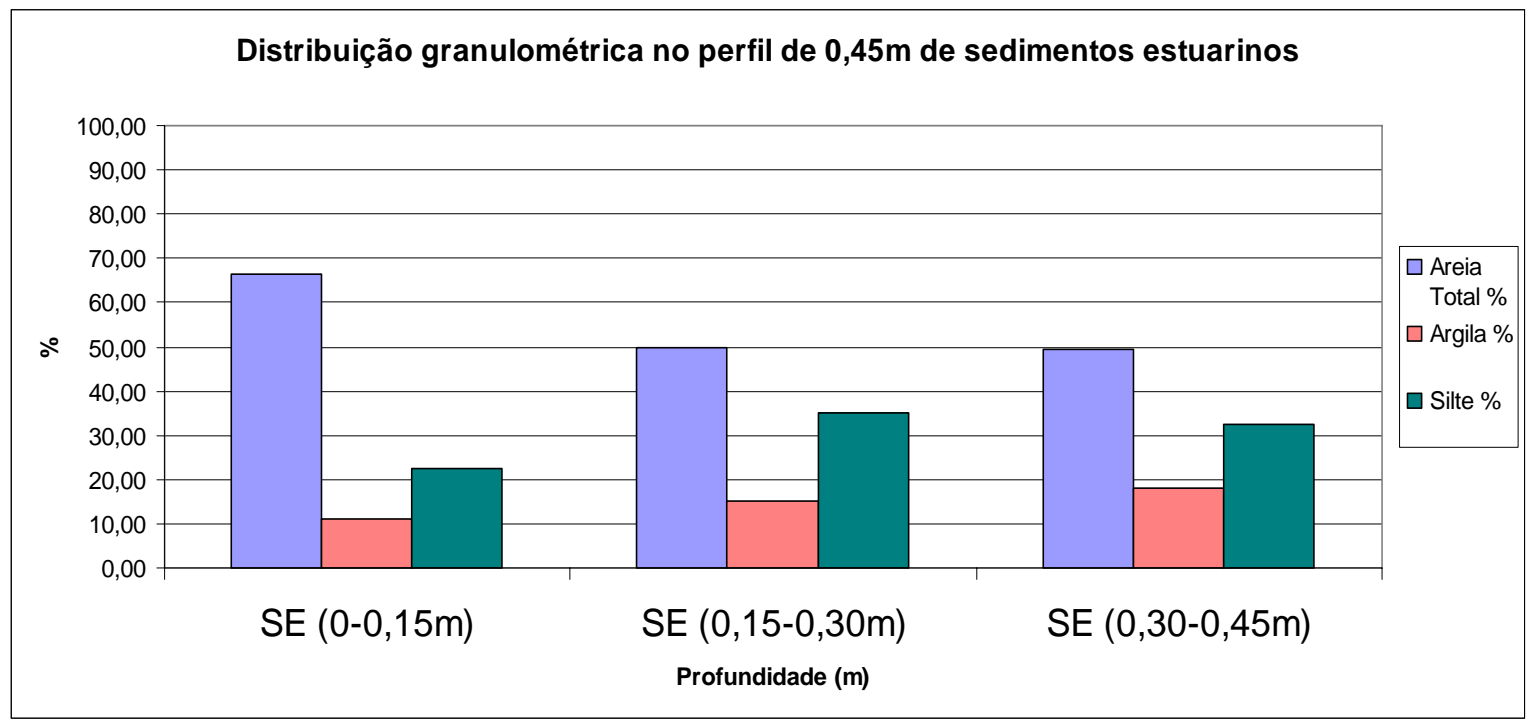

Gráfico 34 - Distribuição granulométrica dos sedimentos estuarinos com a profundidade

A fração areia detectada nestes sedimentos é constituída basicamente pelas frações areia muito fina e areia fina, como indicado no gráfico 35.

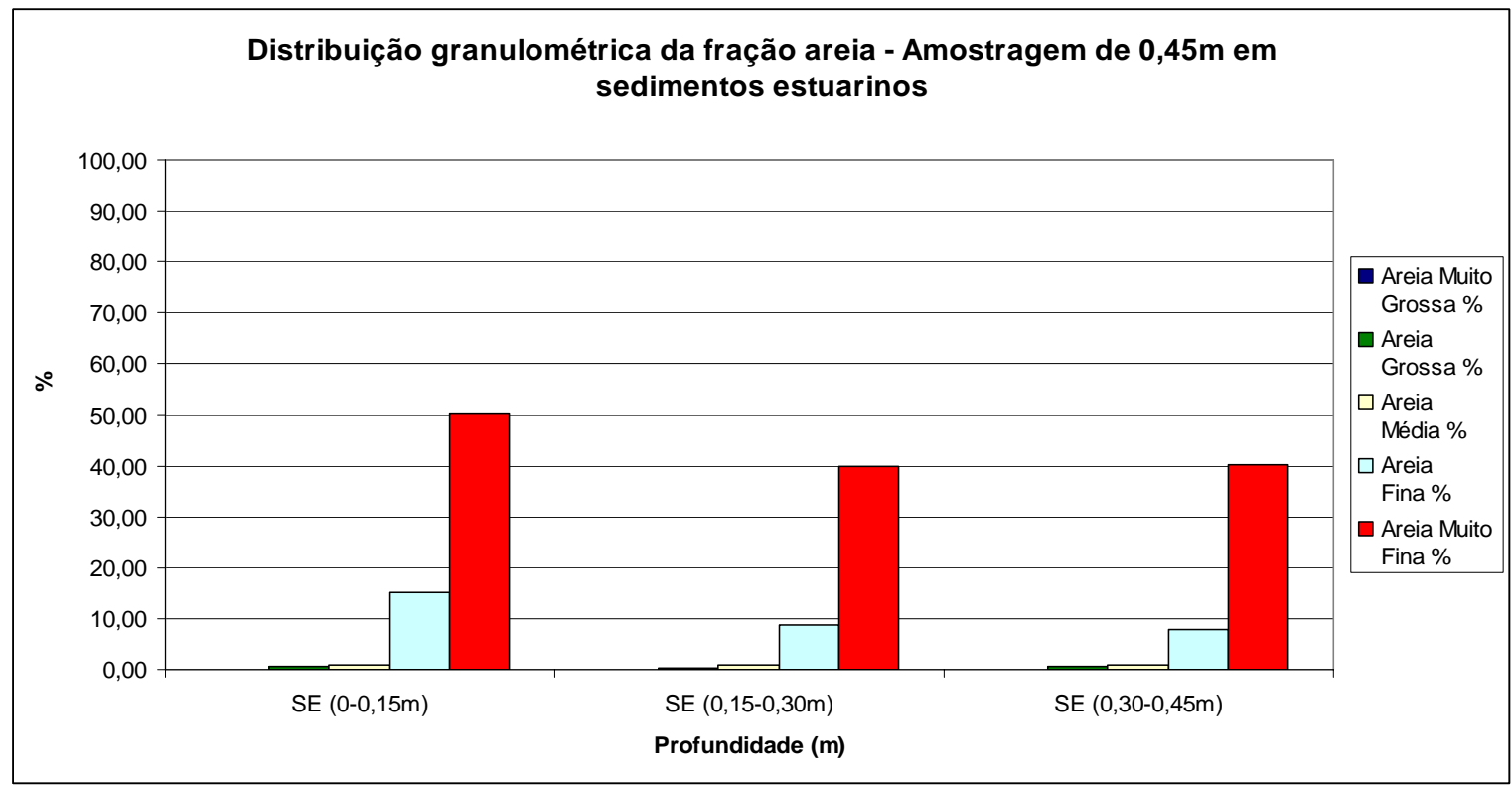

Gráfico 35 - Distribuição granulométrica da fração areia no perfil de sedimento estuarino

Nas análises químicas totais realizadas por FRX constatou-se ser estes sedimentos compostos em média por: $61,63 \% \pm 5,78$ de $\mathrm{SiO}_{2}, 15,93 \% \pm 1,94$ de $\mathrm{Al}_{2} \mathrm{O}_{3}, 6,93 \% \pm 1,41$ de $\mathrm{Fe}_{2} \mathrm{O}_{3}, 2,13 \% \pm 0,11$ de $\mathrm{K}_{2} \mathrm{O}$ e 1,05\% \pm 0,11 de $\mathrm{MgO}$, sendo os outros elementos, inclusive os metais pesados, inferiores a $1 \%$ (Tabela 24 ). 
Tabela 24 - Análise química total por FRX do sedimento estuarino - amostragem de 0,45m - \% de óxidos

\begin{tabular}{|c|c|c|c|c|c|c|c|c|c|c|c|c|c|c|c|c|c|c|c|}
\hline $\begin{array}{c}\text { Amostra } \\
\text { Profundidade }\end{array}$ & $\begin{array}{c}\mathrm{SiO}_{2} \\
\%\end{array}$ & $\begin{array}{c}\mathrm{A}_{2} \mathrm{O}_{3} \\
\%\end{array}$ & $\begin{array}{c}\mathrm{MnO} \\
\%\end{array}$ & $\begin{array}{c}\mathrm{MgO} \\
\%\end{array}$ & $\begin{array}{c}\mathrm{CaO} \\
\%\end{array}$ & $\begin{array}{c}\mathrm{Na}_{2} \mathrm{O} \\
\%\end{array}$ & $\begin{array}{c}\mathrm{K}_{2} \mathrm{O} \\
\%\end{array}$ & $\begin{array}{c}\mathrm{TiO}_{2} \\
\%\end{array}$ & $\begin{array}{c}\mathrm{P}_{2} \mathrm{O}_{5} \\
\%\end{array}$ & $\begin{array}{c}\mathrm{SO}_{3} \\
\%\end{array}$ & $\begin{array}{c}\mathrm{Fe}_{2} \mathrm{O}_{3} \\
\%\end{array}$ & $\begin{array}{c}\mathrm{Cr}_{2} \mathrm{O}_{3} \\
\%\end{array}$ & $\begin{array}{c}\mathrm{CuO} \\
\%\end{array}$ & $\begin{array}{c}\mathrm{BaO} \\
\%\end{array}$ & $\begin{array}{c}\mathrm{ZnO} \\
\%\end{array}$ & $\begin{array}{c}\mathrm{PbO} \\
\%\end{array}$ & $\begin{array}{c}\text { Outros } \\
\%\end{array}$ & $\begin{array}{l}\text { PF } \\
\%\end{array}$ & $\begin{array}{c}\text { Fechamento } \\
\%\end{array}$ \\
\hline$\overline{\mathrm{SE}}(0-0,15 \mathrm{~m})$ & 67,70 & 13,80 & 0,07 & 0,92 & 0,45 & 0,59 & 2,01 & 0,87 & 0,25 & 0,37 & 5,40 & $\mathrm{Nd}$ & $\mathrm{Nd}$ & 0,06 & 0,01 & 0,01 & 0,06 & 7,41 & 99,98 \\
\hline $\mathrm{SE}(0,15-0,30 \mathrm{~m})$ & 61,00 & 16,40 & 0,10 & 1,10 & 0,56 & 0,55 & 2,18 & 0,98 & 0,39 & 0,37 & 7,20 & 0,04 & $\mathrm{Nd}$ & 0,08 & 0,01 & 0,01 & 0,07 & 8,89 & 99,93 \\
\hline SE $(0,30-0,45 m)$ & 56,20 & 17,60 & 0,11 & 1,13 & 0,63 & 0,55 & 2,21 & 0,99 & 0,44 & 0,31 & 8,19 & 0,04 & 0,01 & 0,08 & 0,03 & 0,02 & 0,08 & 11,30 & 99,92 \\
\hline Média & 61,63 & 15,93 & 0,09 & 1,05 & 0,55 & 0,56 & 2,13 & 0,95 & 0,36 & 0,35 & 6,93 & 0,04 & 0,01 & 0,07 & 0,02 & 0,01 & 0,07 & & \\
\hline Erro & 3,33 & 1,12 & 0,01 & 0,07 & 0,05 & 0,01 & 0,06 & 0,04 & 0,06 & 0,02 & 0,82 & 0,00 & 0,00 & 0,01 & 0,01 & 0,00 & 0,01 & & \\
\hline " Desvio Padrão & 5,78 & 1,94 & 0,02 & 0,11 & 0,09 & 0,02 & 0,11 & 0,07 & 0,10 & 0,03 & 1,41 & 0,00 & 0,00 & 0,01 & 0,01 & 0,01 & 0,01 & & \\
\hline & & & & & & & & $\begin{array}{l}\text { rraço } \\
\mathrm{Nd} \text { : }\end{array}$ & $\begin{array}{l}\text { men } \\
\text { ão d }\end{array}$ & $\begin{array}{l}\text { que } 0 \\
\text { ctado }\end{array}$ & & & & & & & & & \\
\hline
\end{tabular}

Nos sedimentos estuarinos foram detectados os seguintes metais pesados: $\mathrm{Zn}, \mathrm{Pb}$, $\mathrm{Cu}$ e $\mathrm{Cr}$. Os teores de $\mathrm{ZnO}, \mathrm{PbO}$ e $\mathrm{CuO}$, principalmente nos primeiros centímetros deste segmento de $45 \mathrm{~cm}$ são muito próximos ao limite de detecção do aparelho empregado na análise $(0,01 \%)$, quando detectados (Tabela 24$)$. Neste caso foram considerados os teores acima de $0,02 \%$, como anteriormente realizado com os sedimentos depositados em bancos de areia, devido à confiabilidade analítica dos dados.

$\mathrm{Na}$ tabela 24, nota-se que Al, Mn, Mg, Ca, K, Ti, P, Fe, Cr, Cu, Zn e Pb concentramse principalmente na porção basal $(0,30-0,45 \mathrm{~m})$. Os únicos que não apresentam esta tendência são Si, Na e S, concentrando-se no topo.

Nos três segmentos analisados, a perda ao fogo mostrou-se sempre elevada, sendo a média de 9,20\%. A amostra basal $(0,30-0,45 \mathrm{~m})$ foi a que apresentou maior teor de perda ao fogo, da ordem de 11,30\%, como observado na tabela 24 .

Visando identificar possibilidade de correlação entre os elementos químicos analisados nas diferentes profundidades deste perfil de sedimento estuarino, juntamente com a granulometria, confeccionou-se matriz de correlação de Pearson (Tabela 25). Esta matriz exibe forte correlação positiva entre: Profundidade-Fração argila; Profundidade-Al; Profundidade-Mn; Profundidade-P; Profundidade-Fe; Profundidade-PF; Fração areia$\mathrm{Na}$; Fração silte-MO; Fração silte-Mg: Fração silte-Ti: Fração silte-Cr; Fração silte-Ba: Fração argila-Al; Fração argila-Mn; Fração argila-Ca; Fração argila-P; Fração argila-Fe; Fração argila-PF; MO-Mg; MO-K; MO-Ti; MO-Cr; MO-Ba; Al-Mn; Al-Mg; Al-Ca; Al-K; Al$\mathrm{Ti} ; \mathrm{Pb}-\mathrm{Cr}$; $\mathrm{Zn}-\mathrm{Cr}$ e $\mathbf{Z n}-\mathbf{P b}$, para isto foram considerados valores obtidos nesta matriz que se situaram acima de 0,95. Observa-se existir forte correlação da distribuição granulométrica com a profundidade, ou seja, os sedimentos são mais finos nas profundidades mais elevadas. Outro fato importante verificado a partir dos resultados obtidos na matriz de correlação são as associações positivas, principalmente entre: $\mathrm{Cr}-\mathrm{Fe}, \mathrm{Ba}-\mathrm{Cr}$, Zn-Cu, $\mathrm{Pb}-\mathrm{Cu}$, $\mathrm{Pb}-\mathrm{Zn}$. Como comentado estes dados servem, apenas como indicativo de possíveis associações entre os diversos elementos aqui analisados. 
Tabela 25 - Matriz de Correlação de Pearson para as frações granulométricas, profundidade, matéria orgânica e elementos químicos nos sedimentos estuarinos

\begin{tabular}{|c|c|c|c|c|c|c|c|c|c|c|c|c|c|c|c|c|c|c|c|c|c|}
\hline & Profundidade & Fração Areia & Fração Silte & Fração Argila & MO & Si & Al & $M n$ & $M g$ & $\mathrm{Ca}$ & $\mathrm{Na}$ & $K$ & $\pi$ & $P$ & $S$ & $\mathrm{Fe}$ & $\mathrm{Cr}$ & $\mathrm{Cu}$ & $\mathrm{Ba}$ & $Z n$ & $P b$ \\
\hline Profundidade & 1,00 & & & & & & & & & & & & & & & & & & & & \\
\hline Fração Areia & $-0,87$ & 1,00 & & & & & & & & & & & & & & & & & & & \\
\hline Fração Silte & 0,75 & $-0,98$ & 1,00 & & & & & & & & & & & & & & & & & & \\
\hline Fração Argila & 1,00 & $-0,91$ & 0,80 & 1,00 & & & & & & & & & & & & & & & & & \\
\hline $\mathrm{MO}$ & 0,83 & $-1,00$ & 0,99 & 0,87 & 1,00 & & & & & & & & & & & & & & & & \\
\hline $\mathrm{Si}$ & $-1,00$ & 0,92 & $-0,81$ & $-1,00$ & $-0,88$ & 1,00 & & & & & & & & & & & & & & & \\
\hline $\mathrm{Al}$ & 0,98 & $-0,96$ & 0,87 & 0,99 & 0,93 & $-0,99$ & 1,00 & & & & & & & & & & & & & & \\
\hline $\mathrm{Mn}$ & 0,96 & $-0,97$ & 0,90 & 0,98 & 0,95 & $-0,98$ & 1,00 & 1,00 & & & & & & & & & & & & & \\
\hline $\mathrm{Mg}$ & 0,92 & $-0,99$ & 0,95 & 0,95 & 0,98 & $-0,96$ & 0,98 & 0,99 & 1,00 & & & & & & & & & & & & \\
\hline $\mathrm{Ca}$ & 0,99 & $-0,93$ & 0,83 & 1,00 & 0,89 & $-1,00$ & 1,00 & 0,99 & 0,97 & 1,00 & & & & & & & & & & & \\
\hline $\mathrm{Na}$ & $-0,87$ & 1,00 & $-0,98$ & $-0,90$ & $-1,00$ & 0,91 & $-0,95$ & $-0,97$ & $-0,99$ & $-0,92$ & 1,00 & & & & & & & & & & \\
\hline K & 0,93 & $-0,99$ & 0,94 & 0,95 & 0,98 & $-0,96$ & 0,98 & 0,99 & 1,00 & 0,97 & $-0,99$ & 1,00 & & & & & & & & & \\
\hline $\mathrm{Ti}$ & 0,90 & $-1,00$ & 0,96 & 0,93 & 0,99 & $-0,94$ & 0,97 & 0,99 & 1,00 & 0,95 & $-1,00$ & 1,00 & 1,00 & & & & & & & & \\
\hline $\mathrm{P}$ & 0,96 & $-0,97$ & 0,90 & 0,98 & 0,95 & $-0,99$ & 1,00 & 1,00 & 0,99 & 0,99 & $-0,97$ & 0,99 & 0,98 & 1,00 & & & & & & & \\
\hline$S$ & $-0,87$ & 0,52 & $-0,32$ & $-0,82$ & $-0,44$ & 0,81 & $-0,74$ & $-0,69$ & $-0,61$ & $-0,80$ & 0,50 & $-0,62$ & $-0,56$ & $-0,70$ & 1,00 & & & & & & \\
\hline $\mathrm{Fe}$ & 0,99 & $-0,94$ & 0,85 & 1,00 & 0,91 & $-1,00$ & 1,00 & 0,99 & 0,97 & 1,00 & $-0,94$ & 0,98 & 0,96 & 0,99 & $-0,77$ & 1,00 & & & & & \\
\hline $\mathrm{Cr}$ & 0,87 & $-1,00$ & 0,98 & 0,90 & 1,00 & $-0,91$ & 0,95 & 0,97 & 0,99 & 0,92 & $-1,00$ & 0,99 & 1,00 & 0,97 & $-0,50$ & 0,94 & 1,00 & & & & \\
\hline $\mathrm{Cu}$ & 0,87 & $-0,52$ & 0,32 & 0,82 & 0,44 & $-0,81$ & 0,74 & 0,69 & 0,61 & 0,80 & $-0,50$ & 0,62 & 0,56 & 0,70 & $-1,00$ & 0,77 & 0,50 & 1,00 & & & \\
\hline $\mathrm{Ba}$ & 0,87 & $-1,00$ & 0,98 & 0,90 & 1,00 & $-0,91$ & 0,95 & 0,97 & 0,99 & 0,92 & $-1,00$ & 0,99 & 1,00 & 0,97 & $-0,50$ & 0,94 & 1,00 & 0,50 & 1,00 & & \\
\hline $\mathrm{Zn}$ & 0,87 & $-0,52$ & 0,32 & 0,82 & 0,44 & $-0,81$ & 0,74 & 0,69 & 0,61 & 0,80 & $-0,50$ & 0,62 & 0,56 & 0,70 & $-1,00$ & 0,77 & 0,50 & 1,00 & 0,50 & 1,00 & \\
\hline $\mathrm{Pb}$ & 0,87 & $-0,52$ & 0,32 & 0,82 & 0,44 & $-0,81$ & 0,74 & 0,69 & 0,61 & 0,80 & $-0,50$ & 0,62 & 0,56 & 0,70 & $-1,00$ & 0,77 & 0,50 & 1,00 & 0,50 & 1,00 & 1,00 \\
\hline PF & 0,99 & $-0,80$ & 0,65 & 0,98 & 0,75 & $-0,97$ & 0,94 & 0,91 & 0,86 & 0,97 & $-0,79$ & 0,87 & 0,83 & 0,92 & $-0,93$ & 0,95 & 0,79 & 0,93 & 0,79 & 0,93 & 0,93 \\
\hline
\end{tabular}

Seguindo o mesmo formato de apresentação dos sedimentos em bancos de areia, são exibidos a seguir os resultados obtidos para os elementos de interesse em grupos assim delimitados: Ca-Mg-Fe e Pb-Zn.

$\underline{\mathrm{Ca}, \mathrm{Mge} \mathrm{Fe}}$

Os teores médios detectados nestes sedimentos para estes elementos foram respectivamente: $\mathrm{CaO}$ de 0,55\%, $\mathrm{MgO}$ de 1,05\% e $\mathrm{Fe}_{2} \mathrm{O}_{3}$ de 6,93\%. Estes teores concentram-se na porção basal (intervalo de 0,30-0,45 m), exibindo curvas de concentrações químicas similares, como observado no gráfico 36.

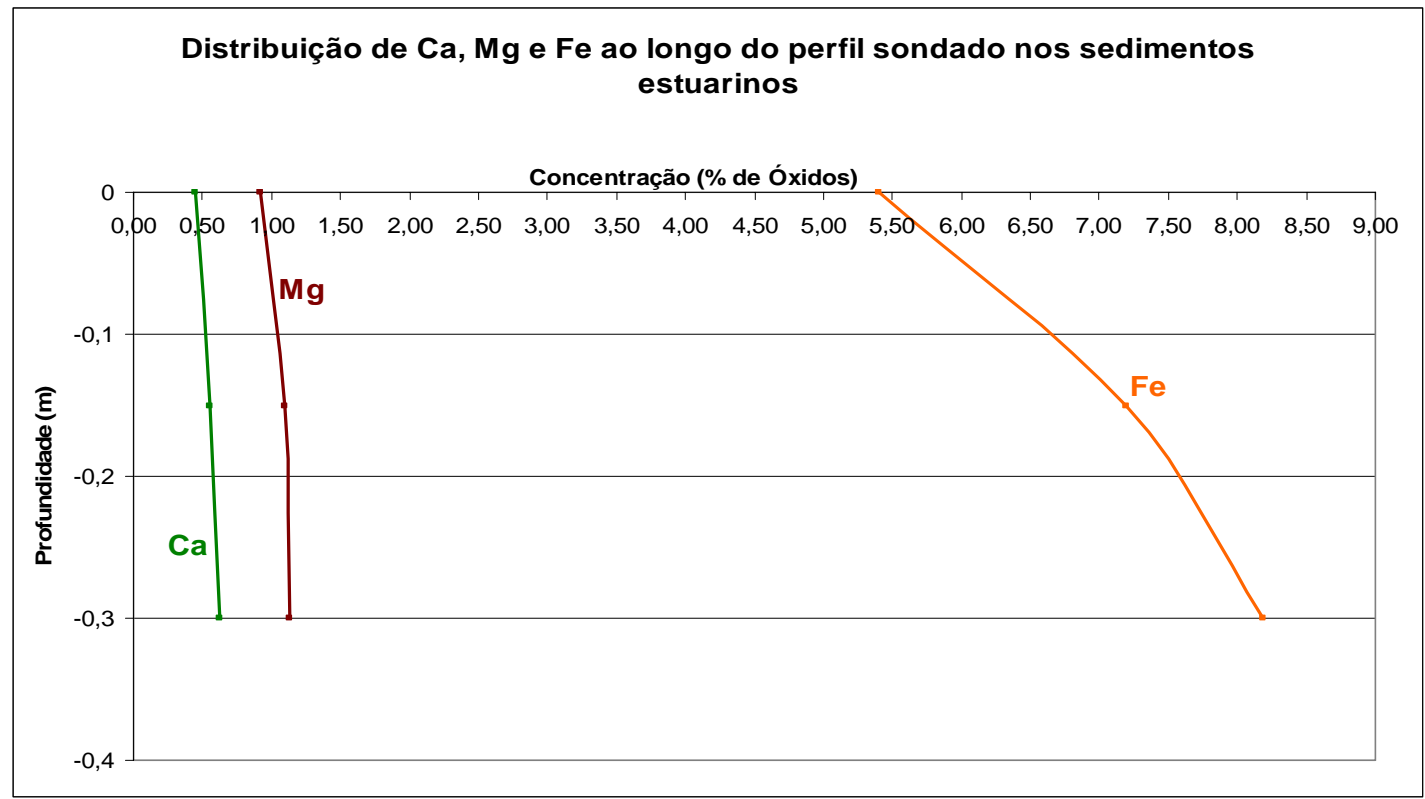

Gráfico 36 - Distribuição de Ca, Mg e Fe no core de sedimento estuarino 


\section{$\underline{\mathrm{Pb} \text { e } \mathrm{Zn}}$}

O teor médio de $\mathrm{Pb}$ detectado nestes sedimentos foi de 124,00 mg/kg, enquanto que o de $\mathrm{Zn}$ foi de 133,33 mg/kg. Estes teores, da mesma forma que observado para o Ca-MgFe, também se concentram na porção basal (intervalo de 0,30-0,45 m), como indicado no gráfico 37.

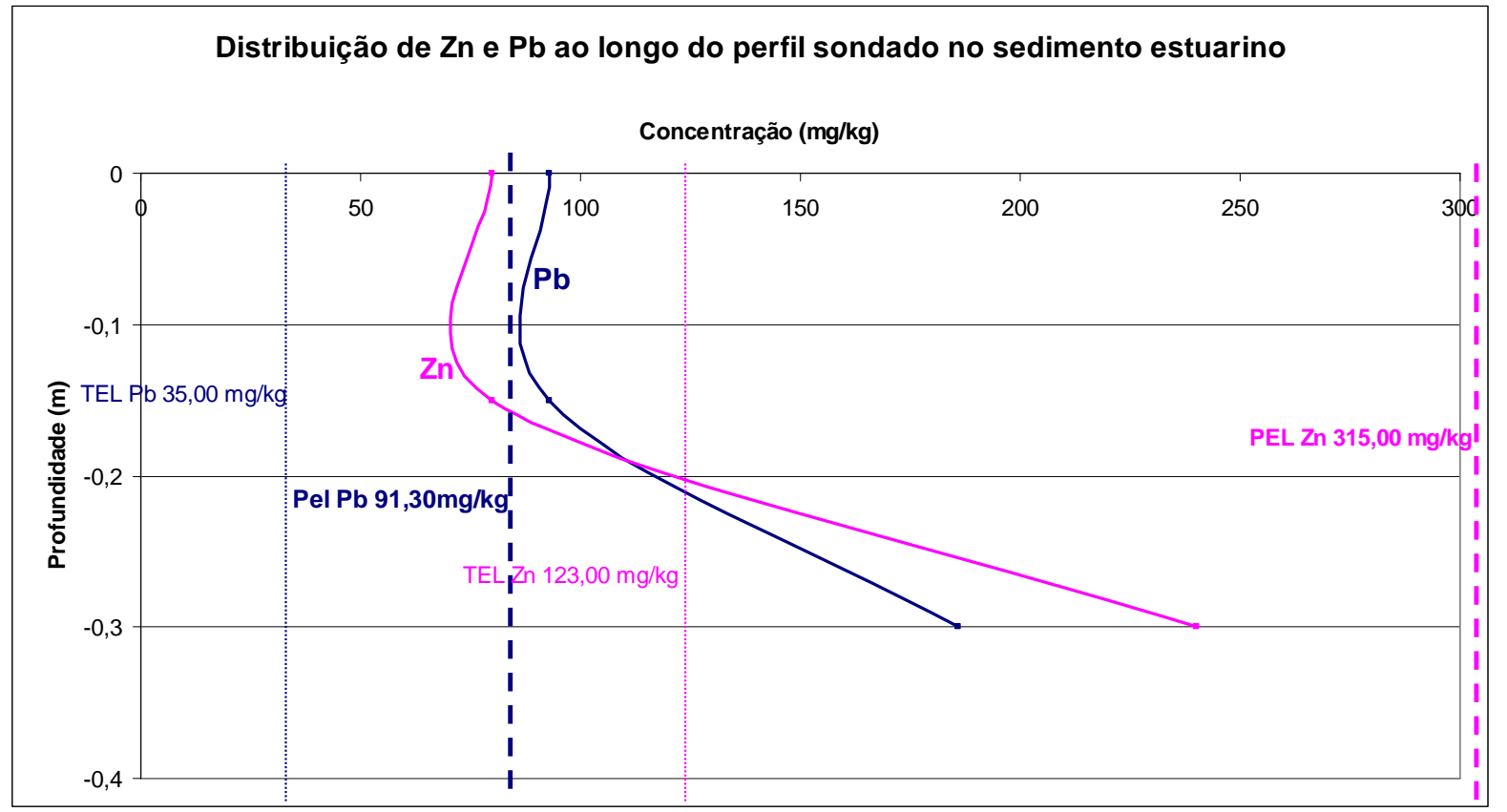

Gráfico 37 - Distribuição de $\mathrm{Pb}$ e Zn no core de sedimento estuarino

Como indicativo da possível contaminação destes metais pesados foi empregado o valor de referência PEL/TEL do CCME (1999), mesmo sendo este padrão adequado para sedimentos de corrente e não para o sedimento aqui abordado. Os teores de $\mathrm{Pb}$ detectados ultrapassam, tanto os valores de referência TEL (alerta) como o PEL (intervenção), em todas as profundidades do core investigado (Gráfico 37).

Os teores de Zn excederam o valor de referencia TEL, apenas no horizonte de 0,300,45 m do core, como indicado no gráfico 37 , nas outras amostras ele está abaixo do PEL e TEL.

\section{Considerações sobre os resultados obtidos}

Como observado nos resultados apresentados, existe uma correlação clara entre a fração granulométrica e a profundidade, quanto maior a profundidade mais fino é o sedimento.

Estes sedimentos são mais ricos em matéria orgânica que os sedimentos em bancos de areia, característica do próprio sedimento estuarino, além de serem mais finos. Estas 
características são mais evidentes na porção basal do segmento amostrado, e conseqüentemente os maiores teores de metais pesados detectados, apresentam-se associados com os sedimentos desta porção.

Ao contrário do que foi observado para os sedimentos depositados em bancos de areia e sedimentos de corrente, os sedimentos em suspensão e o estuarino apresentam $\mathrm{Cu}$ em sua composição. No caso do sedimento estuarino o $\mathrm{Cu}$ foi identificado apenas na amostra basal.

Os dados e resultados aqui obtidos não são suficientes para estabelecer uma comprovação clara quanto a uma origem deposicional mais antiga destes sedimentos no Rio Ribeira de Iguape em condições de maiores concentrações dos metais aqui mencionados.

\subsection{BIOMONITORES}

O termo biomonitor é empregado para designar espécies vivas que acumulam metais pesados ou outras substâncias tóxicas em seus tecidos e por esta razão podem ser utilizados no monitoramento da biodisponibilidade destas substâncias, em um ambiente particular. No Rio Ribeira de Iguape foi encontrado o bivalve da espécie Corbicula fluminea considerado na literatura como organismo biomonitor. Este bivalve foi amostrado em Iporanga, Eldorado, Sete Barras e Registro, mesmos pontos onde foram coletados os sedimentos de corrente, com exceção de Registro, onde não foi possível coletar tais sedimentos.

Estes bivalves para cada ponto de amostragem, exibiram tamanhos variados, sendo observado o predomínio de conchas entre 1,7 a 2,3 cm de comprimento. Foram analisados quimicamente, os tecidos e as carapaças destes bivalves, sendo os resultados obtidos de ambos expostos a seguir.

\subsubsection{Análise dos tecidos de biomonitores}

As determinações de metais pesados nos tecidos de bivalves fornecem algumas informações a respeito dos níveis de contaminação do ambiente pesquisado, pois estes organismos são ótimos filtradores, acumulando as substâncias tóxicas presentes no ambiente aquático com eficiência em seus tecidos. Desta forma para avaliar a possível disponibilidade dos metais pesados adicionados no Rio Ribeira de Iguape a partir das atividades de mineração, analisou-se os tecidos das espécies de Corbicula fluminea coletadas em quatro porções deste rio (CF-Iporanga, CF-Eldorado, CF-Sete Barras e CFRegistro). 
Nestes tecidos (base seca) foram detectados metais pesados essenciais (Cu e Zn) e não essenciais ( $\mathrm{Cd}, \mathrm{Pb}$ e $\mathrm{Cr}$ ) para os processos biológicos desta espécie, como mostra a tabela abaixo.

Tabela 26 - Teores de metais pesados detectados na base seca dos tecidos de Corbicula fluminea - ICP/OES - $\mu \mathrm{g} / \mathrm{g}$

\begin{tabular}{cccccc}
\hline $\begin{array}{c}\text { Amostras } \\
\text { Localidades }\end{array}$ & $\begin{array}{c}\mathrm{Cu} \\
\boldsymbol{\mu g} / \mathbf{g}\end{array}$ & $\begin{array}{c}\mathrm{Zn} \\
\mathbf{g g} / \mathbf{g}\end{array}$ & $\begin{array}{c}\mathbf{C d} \\
\boldsymbol{\mu g} / \mathbf{g}\end{array}$ & $\begin{array}{c}\mathbf{P b} \\
\boldsymbol{\mu g} / \mathbf{g}\end{array}$ & $\begin{array}{c}\mathrm{Cr} \\
\mathbf{\mu g} / \mathbf{g}\end{array}$ \\
\hline \hline CF - Iporanga & $20,10 \pm 0,8$ & $163,20 \pm 1,6$ & $0,67 \pm 0,02$ & $4,53 \pm 0,06$ & $9,82 \pm 0,11$ \\
CF - Eldorado & $22,95 \pm 0,55$ & $115,95 \pm 2,9$ & $0,64 \pm 0,01$ & $0,82 \pm 0,03$ & $5,37 \pm 0,11$ \\
CF - Sete Barras & $17,60 \pm 0,3$ & $180,90 \pm 1,7$ & $0,82 \pm 0,02$ & $3,77 \pm 0,07$ & $9,64 \pm 0,07$ \\
CF - Registro & $35,30 \pm 0,7$ & $116,80 \pm 3,3$ & $0,71 \pm 0,02$ & $0,51 \pm 0,08$ & $3,59 \pm 0,12$ \\
\hline
\end{tabular}

Os valores médios de metais pesados detectados nos tecidos desta espécie de bivalve no Rio Ribeira de Iguape foram da ordem de: $23,99 \mu \mathrm{g} / \mathrm{g}$ de $\mathrm{Cu}, 144,21 \mu \mathrm{g} / \mathrm{g}$ de $\mathrm{Zn}$, $0,71 \mu \mathrm{g} / \mathrm{g}$ de $\mathrm{Cd}, 2,41 \mu \mathrm{g} / \mathrm{g}$ de $\mathrm{Pb}$ e $7,11 \mu \mathrm{g} / \mathrm{g}$ de $\mathrm{Cr}$. Neste rio, os tecidos de Corbicula fluminea coletados em Iporanga exibiram teores mais elevados de $\mathrm{Pb}(4,53 \mu \mathrm{g} / \mathrm{g})$ e de $\mathrm{Cr}$ $(9,82 \mu \mathrm{g} / \mathrm{g})$, os coletados nas Corbiculas flumineas amostradas em Sete Barras apresentaram valores mais elevados para o $\mathrm{Zn}(180,90 \mu \mathrm{g} / \mathrm{g})$ e $\mathrm{Cd}(0,82 \mu \mathrm{g} / \mathrm{g})$ e os de Registro mostraram maiores teores de $\mathrm{Cu}(35,30 \mu \mathrm{g} / \mathrm{g})$, como observados na tabela 26 e no gráfico 38.

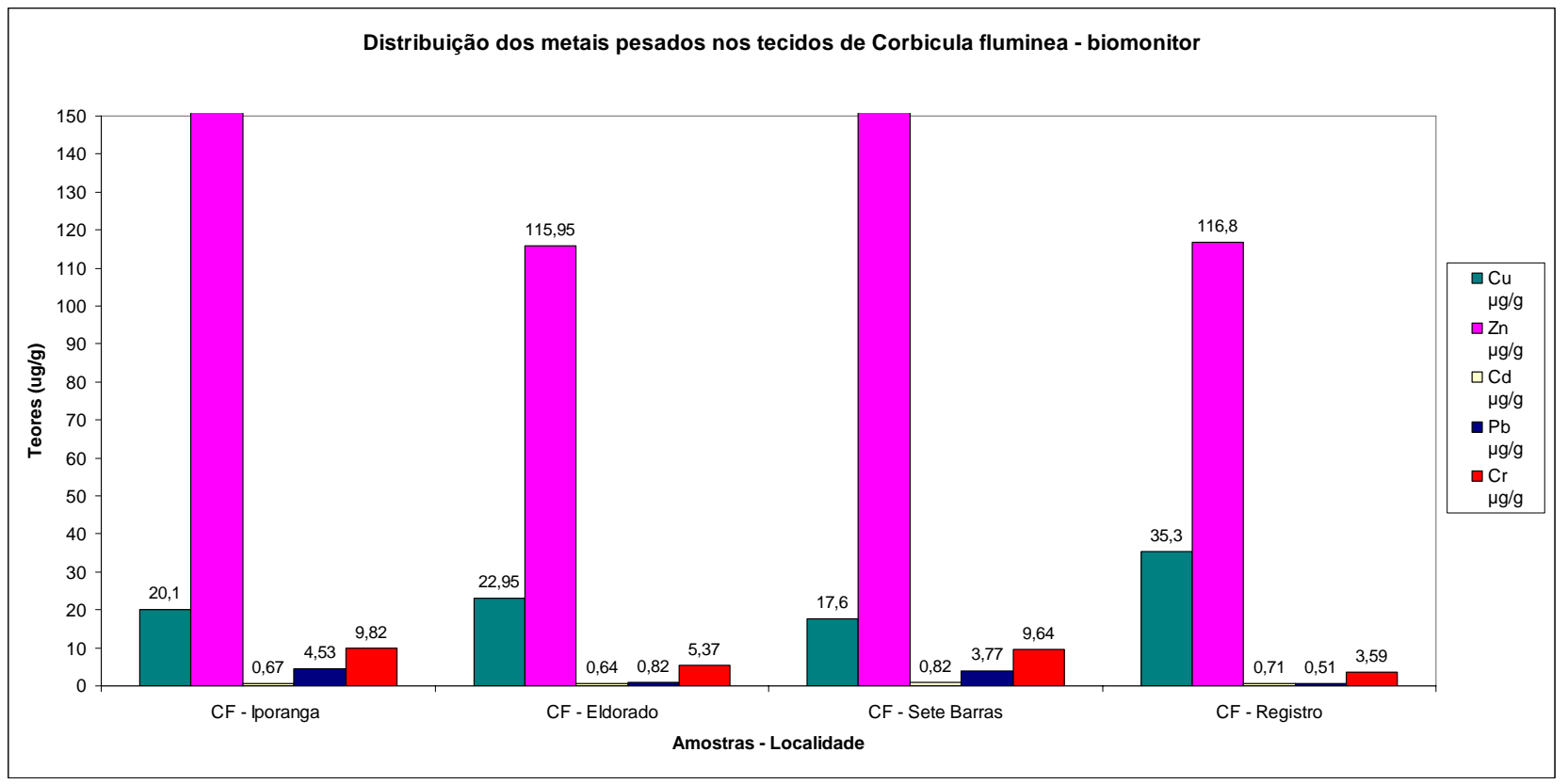

Gráfico 38 - Distribuição dos teores de metais pesados nos tecidos (base seca) das Corbiculas flumineas coletadas ao longo do Rio Ribeira de Iguape 
Para todos os metais pesados investigados, notam-se variações dos teores de uma localidade para outra, não é gradual o aumento ou decréscimo destas concentrações (Tabela 26). Isso ocorre, principalmente em decorrência do tamanho, idade e outros fatores fisiológicos dos bivalves analisados.

As concentrações de $\mathrm{Pb}$ detectadas nos tecidos dos bivalves coletados em Iporanga $(4,53 \mu \mathrm{g} / \mathrm{g})$ e Sete Barras $(3,77 \mu \mathrm{g} / \mathrm{g})$ ultrapassam os limites máximos de tolerância para contaminantes inorgânicos em peixes e produtos de pesca estabelecidos pela legislação brasileira, valor de referência estabelecido pela Portaria 658/98 da ANVISA (ANVISA, 1998), equivalente a 2,0 $\mu \mathrm{g} / \mathrm{g}$ para este metal pesado. Este padrão de referência foi empregado como indicativo de possível contaminação, tendo certa restrição quanto ao uso deste padrão em face deste ser empregado genericamente e não especificamente para os bivalves da espécie Corbicula fluminea, existindo variabilidade das condições fisiológicas dos organismos e dos parâmetros físico-quimicos do ambiente.

Em todas as amostras o Cd está abaixo do padrão estabelecido pela Portaria 685/98 da ANVISA (ANVISA, 1998) que é da ordem de 1,0 $\mu \mathrm{g} / \mathrm{g}$, como observado na tabela 26.

Para verificar se os outros metais pesados detectados estavam em conformidade com teores obtidos para as Corbiculas flumineas detectadas em ambientes fluviais não contaminados e contaminados, comparou-se os teores aqui obtidos com os encontrados por outros pesquisadores, como visualizado no quadro abaixo.

Quadro 1 - Comparação de $\mathrm{Cu}, \mathrm{Cd}, \mathrm{Pb}$, Cr e Zn em Corbiculas flumineas de várias localidades, em áreas contaminadas e não contaminadas. Intervalo de Concentração e Média \pm Desvio Padrão ( $\mu$ g/g em peso seco)

\begin{tabular}{|c|c|c|c|c|c|c|}
\hline Locais de Coleta & $\begin{array}{c}\mathrm{Cu} \\
\mu \mathrm{g} / \mathrm{g}\end{array}$ & $\begin{array}{c}\mathrm{Cd} \\
\mu \mathrm{g} / \mathrm{g}\end{array}$ & $\begin{array}{c}\mathrm{Pb} \\
\mu \mathrm{g} / \mathrm{g}\end{array}$ & $\begin{array}{c}\mathrm{Cr} \\
\mu \mathrm{g} / \mathrm{g}\end{array}$ & $\begin{array}{c}\mathrm{Zn} \\
\mu \mathrm{g} / \mathrm{g}\end{array}$ & Referências \\
\hline "Rio Shatt al-Arab (Iraque) & 40-1065* & $2,2-70^{\star}$ & $0,3-3,2$ & nd & $31-83^{\star}$ & Abaychi \& Mustafa (1988) \\
\hline Rio de La Plata (Argentina) & $45 \pm 18$ & $1,1 \pm 0,4$ & nd & $5,2 \pm 2,8$ & $197 \pm 54$ & Bilos et al. (1998) \\
\hline New River (Va, USA) & $6,3-12$ & $5,9-6,9$ & nd & $8,2-55$ & $500-564$ & Rodgers et al. (1980) \\
\hline $\begin{array}{l}\text { Rios do Estado } \\
\text { de São Paulo }\end{array}$ & $0,39 \pm 0,33$ & nd & $3,67 \pm 3,87$ & nd & nd & Tomazelli (2003) \\
\hline
\end{tabular}

As Corbiculas flumineas aqui investigadas exibiram baixas concentrações de $\mathrm{Cd}$ (média de 0,71 $\mu \mathrm{g} / \mathrm{g}$ ), sendo estas inferiores às detectadas em áreas contaminadas por este metal pesado, como visualizado no quadro 1. Estas concentrações são mais elevadas que as encontradas em bivalves de água doce relatados por Czarnezki (1987) para ambiente não contaminado, cujo teor detectado foi de $0,32 \mu \mathrm{g} / \mathrm{g}$ em espécies de Lampsilis Ventricosa.

$\mathrm{O}$ teor de $\mathrm{Pb}$ detectado na amostra de Iporanga encontra-se acima dos valores relatados em outros trabalhos realizados com esta mesma espécie de bivalve (Quadro 1) e 
como abordado anteriormente. O mesmo ultrapassa o valor de referência deste metal pesado estabelecido pela ANVISA (1998) definido para o consumo e comercialização de peixes e produtos de pesca. Em todas as amostras aqui analisadas os teores de $\mathrm{Pb}$ foram maiores que os considerados para ambientes não contaminados, determinados em bivalves de água doce de várias espécies, como as que foram relatadas por Czarnezki (1987) em espécies de Lampsilis Ventricosa, cujo teor foi da ordem de 0,42 $\mu \mathrm{g} / \mathrm{g}$.

No geral, as Corbiculas flumineas coletadas no Rio Ribeira de Iguape não apresentaram enriquecimentos nos teores de $\mathrm{Cu}, \mathrm{Cr}$ e $\mathrm{Zn}$, apresentando valores da mesma ordem de grandeza que os detectados nesta mesma espécie que não se encontravam contaminadas por tais metais (Quadro 1 - Bilos et al. 1998). Quando comparados os teores aqui detectados para estes três metais pesados com os relatados em Rodgers et al. (1980), para esta mesma espécie de bivalve, verifica-se que os teores de $\mathrm{Zn}$ e $\mathrm{Cr}$ obtidos por este pesquisador estão bem acima dos detectados neste trabalho (Quadro 1), sendo considerados tóxicos neste caso. O Zn e Cu são considerados elementos essenciais para os organismos e os teores aqui encontrados são da mesma ordem de grandeza para estas espécies não contaminadas por estes elementos.

Considerações sobre os resultados obtidos

Os resultados nos tecidos secos das Corbiculas flumineas amostradas ao longo do Rio Ribeira de Iguape, exibem a existência da disponibilidade química de $\mathrm{Pb}$ e Cd neste rio para estas espécies de bivalves seguramente provenientes da atividade de mineração que ocorreu por longo período nas proximidades deste rio.

Os valores de $\mathrm{Pb}$ detectados nas amostras de Iguape são mais elevados que os relatados em outros estudos para este bivalve e também, ultrapassam o valor de referência da ANVISA para a concentração deste metal pesado em peixes e produtos de pesca para consumo. Por outro lado, o teor de Cd encontra-se abaixo do valor de referência da ANVISA, bem como dos valores relatos em outros trabalhos detectados nas Corbiculas flumineas consideradas contaminadas por este elemento.

Como identificado nas análises químicas realizadas nos sedimentos de banco de areia e sedimentos de corrente, os maiores teores de $\mathrm{Pb}$, também estavam concentrados nas amostras localizadas em Iporanga, o que possivelmente deve estar indicando que estes bivalves estão acumulando este metal em seus tecidos, ou pela filtragem do material presente na coluna d'água (via respiração, estando este metal na forma dissolvida) ou a partir da alimentação dos materiais encontrados no leito do rio (via ingestão, sedimentos finos), como apresentado em Hakenkamp e Palmer (1999). 
Os teores de $\mathrm{Cu}$ e $\mathrm{Zn}$ detectados no presente estudo foram da mesma ordem de grandeza que os encontrados por Bilos et al. (1998). Estes teores não são considerados tóxicos, sendo estes metais pesados considerados essenciais para vários sistemas enzimáticos presentes nestes organismos.

As variações verificadas nos teores dos elementos de um ponto de coleta para o outro (Tabela 26), é relatado na bibliografia, tendo como causa, o fator tamanho-peso, o que não foi possível verificar neste estudo em decorrência da pequena quantidade de espécimes obtidos e conseqüentemente também de tecido extraído em cada local de amostragem. $\mathrm{Na}$ literatura, é relatada que estas variações nas concentrações de metais pesados nos tecidos dos bivalves em um ambiente aquático de água doce, provavelmente são geradas pelas seguintes variáveis: estação do ano que foi realizada a coleta, tipo do tecido analisado, sexo ou hábitos alimentares, idade e peso ou tamanho do tecido do bivalve.

Resumidamente, as comparações aqui realizadas com teores detectados em Corbiculas flumineas de outras localidades, bem como com outros bivalves de água doce, devem ser considerados apenas como uma referência, uma vez que se tratam de ambientes diferentes com condições físico-químicas distintas e também, de espécies com tamanhos, peso e idades diferentes, as quais podem apresentar distintos índices de acúmulos dos metais pesados, como já verificado em Tomazelli (2003).

De modo geral, verifica-se integração dos resíduos lançados no Rio Ribeira de Iguape e sua possível biodisponibilidade para biota, principalmente no caso do $\mathrm{Pb}$ e $\mathrm{Cd}$, contidos nestes resíduos.

\subsubsection{Análise das carapaças de biomonitores}

Visando comparação direta com os metais pesados encontrados nos tecidos das Corbiculas flumineas, separou-se todas as carapaças dos indivíduos coletados (CFIporanga, CF-Eldorado, CF-Sete Barras e CF-Registro), sendo estas encaminhadas para análise química total por ICPIAES. Os resultados obtidos podem ser visualizados na tabela 27, os quais foram comparados com análises de carapaças de espécies de Corbiculas flumineas não contaminadas (branco analítico do Rio Turvo). 
Tabela 27 - Teores de metais pesados detectados nas carapaças de Corbicula fluminea - ICP/AES - $\mu$ g/g

\begin{tabular}{ccccc}
$\begin{array}{c}\text { Amostras } \\
\text { Localidades }\end{array}$ & $\begin{array}{c}\mathrm{Cu} \\
\boldsymbol{\mu g} / \mathbf{g}\end{array}$ & $\begin{array}{c}\mathrm{Zn} \\
\boldsymbol{\mu g} / \mathbf{g}\end{array}$ & $\begin{array}{c}\mathrm{Pb} \\
\boldsymbol{\mu g} / \mathbf{g}\end{array}$ & $\begin{array}{c}\mathrm{Cr} \\
\boldsymbol{m g} / \mathbf{g}\end{array}$ \\
\hline \hline CF-Iporanga & $8,51 \pm 0,03$ & $9,87 \pm 0,06$ & $3,81 \pm 0,12$ & $1,42 \pm 0,01$ \\
CF-Eldorado & $5,66 \pm 0,08$ & $5,77 \pm 0,25$ & $1,95 \pm 0,06$ & $1,43 \pm 0,01$ \\
CF-Sete Barras & $8,47 \pm 0,04$ & $2,26 \pm 0,00$ & $1,01 \pm 0,02$ & $1,31 \pm 0,01$ \\
CF-Registro & $5,96 \pm 0,00$ & $2,34 \pm 0,08$ & $0,75 \pm 0,13$ & $1,37 \pm 0,03$ \\
\hline $\begin{array}{c}\text { Branco Analítico } \\
\text { Rio Turvo }\end{array}$ & $6,06 \pm 1,03$ & $1,56 \pm 0,63$ & $<0,2$ & $1,60 \pm 0,03$ \\
\hline
\end{tabular}

$\mathrm{Na}$ tabela 27 , nota-se que os mesmos metais pesados $(\mathrm{Cu}, \mathrm{Zn}, \mathrm{Pb}$ e $\mathrm{Cr}$ ) anteriormente encontrados nos tecidos destes biomonitores, também aparecem em suas carapaças, com exceção do Cd, o qual não foi detectado.

Como já era esperado, o teor dos metais essenciais bem como dos não essenciais para estes organismos, são menores nas carapaças que nos tecidos (Tabelas 26 e 27).

Os valores médios destes metais nas carapaças da espécie Corbiculas flumineas foram da ordem de: 7,15 $\mu \mathrm{g} / \mathrm{g}$ de $\mathrm{Cu}, 5,06 \mu \mathrm{g} / \mathrm{g}$ de $\mathrm{Zn}, 1,88 \mu \mathrm{g} / \mathrm{g}$ de $\mathrm{Pb}$ e 1,38 $\mu \mathrm{g} / \mathrm{g}$ de $\mathrm{Cr}$. Neste rio, as carapaças coletadas em Iporanga exibiram teores mais elevados para o $\mathrm{Cu}, \mathrm{Zn}$ e $\mathrm{Pb}$, como observados na tabela 27 e no gráfico 39. O maior teor de $\mathrm{Cr}$ foi detectado na amostra coletada em Eldorado (Gráfico 39).

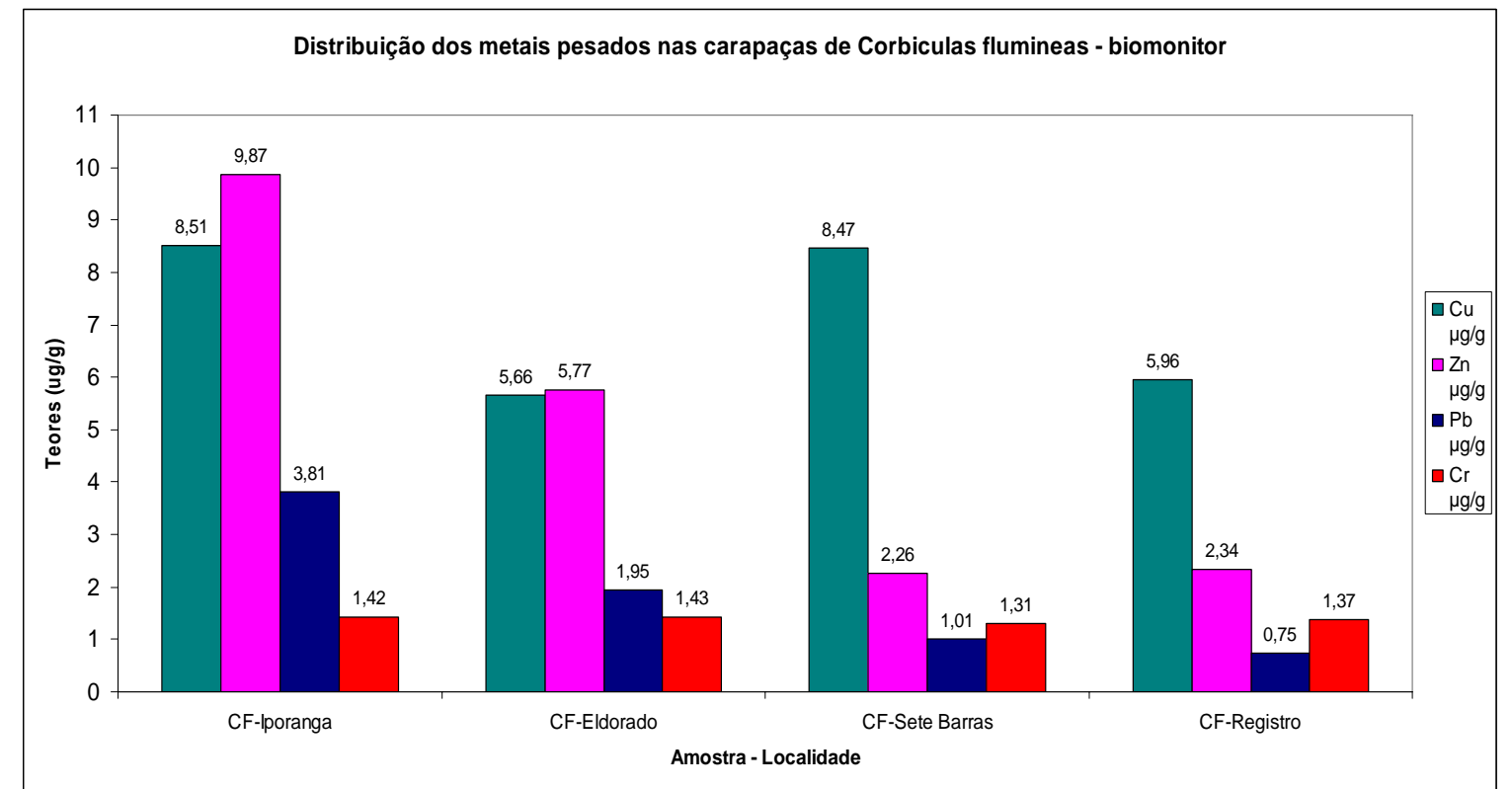

Gráfico 39 - Distribuição dos teores de metais pesados nas carapaças das Corbiculas flumineas coletadas ao longo do Rio Ribeira de Iguape 
Os metais pesados aqui determinados para as carapaças de Corbiculas flumineas foram comparados com os resultados obtidos nas carapaças desta mesma espécie de bivalve em um ambiente não contaminado (branco analítico), os quais demonstraram ser o teor de $\mathrm{Pb}$ no Rio Ribeira de Iguape quase 7 vezes o valor deste metal nos bivalves provenientes da área não contaminada. No caso da amostra coletada em Iporanga, este teor chega a ser 19 vezes maior que o detectado na amostra do branco analítico.

Basicamente as médias obtidas para os teores de Cu $(5,06 \mu \mathrm{g} / \mathrm{g}), \mathrm{Zn}(1,88 \mu \mathrm{g} / \mathrm{g})$ e $\mathrm{Cr}$ $(1,38 \mu \mathrm{g} / \mathrm{g})$ nas amostras do Rio Ribeira de Iguape são da mesma ordem de grandeza que as detectadas no branco analítico (Tabela 27).

Considerações sobre os resultados obtidos

Este estudo demonstrou que além dos tecidos, está ocorrendo também concentração de metais pesados nas carapaças das Corbiculas flumineas, principalmente do metal chumbo, que é um elemento não essencial para estes organismos e tem sua origem ligada à atividade extrativa de origem sabidamente antrópica, realizada nas cabeceiras do Rio Ribeira de Iguape.

Como identificado nas análises químicas realizadas nos tecidos dos bivalves, os maiores teores de $\mathrm{Pb}$, também foram detectados nas amostras localizadas em Iporanga, o que seguramente indica estarem estes bivalves acumulando este metal em seus tecidos e em suas carapaças, além de demonstrar que neste trecho do rio ocorre acumulação e biodisponibilidade deste metal para a biota.

Os teores de $\mathrm{Cr}$, Cu e $\mathrm{Zn}$ detectados no presente estudo foram da mesma ordem de grandeza que os encontrados na amostra empregada como branco analítico, coletada no Rio Turvo, indicando assim que estas concentrações, provavelmente são tidas como normais nas análises realizadas em carapaças destas espécies de bivalves.

Não existe na literatura nenhum padrão de referência para estes metais pesados em carapaças de biomonitores da espécie Corbiculas flumineas, sendo, pois este procedimento de análise nesta Tese inédito. Tal procedimento, no entanto apenas corroborou com os resultados obtidos nos tecidos deste biomonitor e permitiu deixar bastante claro que o fato das carapaças terem estrutura fundamentada em carbonatos de cálcio com algum magnésio, favoreceu a absorção dos rejeitos de mineração por este organismo. As comparações aqui realizadas, no entanto, com teores detectados em uma amostra coletada em um ambiente não contaminado devem ser consideradas apenas como uma referência, uma vez que os diversos locais de coleta compreendem ambientes diferentes com condições físico-químicas distintas podendo vir a permitir localmente maior ou menor 
disponibilidade de elementos potencialmente tóxicos para assimilação por esta variedade de biomonitor. 


\section{DISCUSSÃO}

Com base nas análises realizadas ficou evidente que os principais poluidores, delimitados pelos resíduos da mineração e pelas escórias de metalurgia, interagem fortemente com os sedimentos e biota, no Rio Ribeira de Iguape. A seguir serão apresentadas as principais discussões referentes a cada um destes compartimentos: Resíduos de Mineração e Metalurgia (fontes de poluição e/ou contaminação); Sedimentos (interação das fontes poluentes no Rio Ribeira de Iguape com os sedimentos, locais de maior deposição destes contaminantes e determinação da fonte contaminante no sedimento) e Biomonitor (interação dos metais pesados com a biota).

\subsection{Resíduos da Mineração e Metalurgia}

Neste estudo, a primeira pergunta inserida foi sobre a proveniência e comportamento das fontes de poluição: resíduos da mineração (rejeitos do concentrado da Mina do Rocha e da Plumbum) e resíduos da metalurgia (escórias). Com base neste aspecto, fez-se a seguinte indagação: Estariam estas fontes, ainda hoje, contribuindo para poluição e/ou contaminação deste ambiente aquático, tanto pelo material que foi lançado no rio por aproximadamente 40 anos, como pelas pilhas de rejeitos e escória depositadas nas proximidades do Rio Ribeira de Iguape?

A resposta para esta indagação induziu a uma investigação detalhada que incluiu testes de lixiviação como preconizado na norma (NBR 10.005) da ABNT, os quais demonstraram ser estes resíduos tóxicos, tendo sido enquadrados como resíduos sólidos Classe I, em decorrência, principalmente dos elevados teores de $\mathrm{Pb}$ que, ultrapassaram em 32 vezes (Mina do Rocha), 41 vezes (Plumbum) e 34 vezes (escória), o valor deste metal pesado fixado por tal norma.

Além da realização do teste de lixiviação investigou-se a possibilidade real ou não, da formação de drenagem ácida nas pilhas de rejeito do concentrado, tanto da Mina do Rocha como da Plumbum. A existência de tal drenagem traria conseqüências drásticas para este sistema aquático, pois os metais pesados presentes em altas concentrações nestes dois rejeitos seriam mais facilmente liberados para o meio ambiente. Este tipo de drenagem ocorre em depósitos minerais com predomínio de sulfetos de ferro (pirita, marcassita, pirrotita, calcopirita, etc), os quais em contato com oxigênio e água, liberam após diferentes reações químicas, ácido sulfúrico, tornando o pH do meio ácido e com isso gerando maior mobilidade dos metais pesados. 
No caso dos dois rejeitos do concentrado aqui investigados, não foi detectada a geração de drenagem ácida, mesmo tendo sido registrada a presença nestes depósitos de sulfetos de ferro (principalmente, pirita e pirrotita). A formação desta drenagem não ocorre nestas pilhas, devido a grande quantidade de carbonatos, tanto de Ca como de Mg, reflexo da litologia das rochas encaixantes do minério extraído. Estes acabam por neutralizar ou representar mecanismo tampão para com o pH do meio, tornando-o de neutro a alcalino, dependendo do resíduo em questão.

Desta forma, os resultados obtidos na análise química demonstraram ser o resíduo da Plumbum o mais comprometedor para manutenção da qualidade do meio ambiente, pois os teores de Ca são menores que os detectados para o rejeito da Mina do Rocha, além de exibir teores um pouco mais elevados de $\mathrm{S}$. Tal fato reflete diretamente no $\mathrm{pH}$ obtido nestas pilhas, sendo que este parâmetro é menor para os rejeitos da Plumbum $(7,12)$ que para os do Rocha $(8,57)$, tornando o primeiro resíduo mais suscetível e passível de liberação dos metais pesados nele presentes.

Ainda com relação à composição química destes dois rejeitos do concentrado, verificou-se que estes são compostos por elementos químicos e por concentrações distintas dos diversos elementos aqui analisados. Os rejeitos da Mina do Rocha são constituídos predominantemente por $\mathrm{Ca}$ e $\mathrm{Mg}$, reflexos da rocha encaixante que foi beneficiada pela empresa Rocha Comércio e Exploração de Minério Ltda, na própria área da mina. Os rejeitos da Plumbum apresentaram teores elevados de $\mathrm{Ba}$, como já relatado por Moraes (1997), refletindo, principalmente, o processamento do minério da Mina de Canoas que é do tipo Perau, o qual é constituído por níveis baritíferos cujas concentrações em Ba são sabidamente elevadas, explicando assim os altos teores deste elemento neste material.

Nas caracterizações realizadas com estes resíduos de mineração foi comprovado que estes materiais estão sofrendo processos de alterações, evidenciados pela presença de minerais neoformados e por degradação de minerais primários, como abordado no capítulo resultados. Este fato, já havia sido descrito por Leal (2002) e Franchi (2004) que observaram na pilha de rejeitos do Rocha aspectos que confirmaram a atuação de processos de degradação mineral dos minerais primários correspondentes, principalmente as mineralizações de Pb e metais associados. Capellozza (2006), também observou para os rejeitos da Plumbum, que os mesmos também estão sofrendo processos de transformação química em decorrência da atuação de agentes intempéricos, resultando na transformação de minerais primários e neoformação mineral nesta pilha.

Todos os fatos aqui apresentados comprovam a suposição anterior de que o resíduo da Plumbum é mais suscetível à ação de agentes intempéricos e conseqüentemente à 
lixiviação, sendo assim mais passíveis de disponibilizar os metais para o meio ambiente. Além disso, o rejeito do Rocha tem outro atenuante, que seria a sua remoção, durante a execução desta pesquisa, para o interior de uma cava, minimizando desta forma os possíveis efeitos nocivos ao meio ambiente pelo menos no que tange a permanência de resíduos de mineração em superfície como o que ocorre até o presente momento.

Desta forma, as fontes atuais de contaminação representadas pelos resíduos produzidos durante beneficiamento e fundição do minério que estão depositadas diretamente sob o solo e expostas aos agentes intempéricos, são os resíduos da mineração da Plumbum e o resíduo da metalurgia, ambos depositados nas proximidades de uma das margens do Rio Ribeira de Iguape no município de Adrianópolis (PR). Cabe ressaltar, que mesmo o rejeito do Rocha, não sendo considerado um problema atual pela sua remoção, foi lançado no Ribeirão do Rocha por um longo período durante a fase de explotação mineral e provavelmente deve ter sofrido interação com o sistema aquático; o mesmo se aplica para os resíduos de mineração e da metalurgia da Plumbum.

$\mathrm{Na}$ pesquisa realizada por Moraes (1997), constatou-se que as fontes poluidoras do Rio Ribeira de Iguape estavam associadas aos rejeitos produzidos no Alto Vale do Ribeira durante a fase de explotação do minério. As análises isotópicas indicaram que estes rejeitos eram provenientes do tratamento e beneficiamento do minério do tipo Panelas. Neste trabalho não foi averiguado o papel da escória como agente poluidor. Desta forma, os estudos aqui apresentados mostraram que o resíduo da metalurgia, também é bastante preocupante quanto ao seu conteúdo de metais potencialmente tóxicos, pois apresenta teores muito elevados de $\mathrm{Pb}$ e $\mathrm{Zn}$, principalmente deste último.

As escórias aparentemente podem ser consideradas mais tóxicas que os outros resíduos, devido aos grandes teores de $\mathrm{Zn}$ e $\mathrm{Pb}$. Mesmo sendo a escória mais enriquecida em metais pesados, o resíduo da mineração apresenta características ambientalmente mais comprometedoras, tais como: granulometria bem mais fina que a escória, podendo ser disperso pelo vento, além de estar mais próximo da margem do Rio Ribeira de Iguape e ter apresentado maior teor de $\mathrm{Pb}$ no teste de lixiviação.

Esta constatação permite afirmar que a escória também deve ser monitorada, pois como já comentado, os teores dos metais pesados contidos neste material é extremamente elevado, além da mesma poder ser transportada por longa distância. Foi observado que os grãos de escória com o atrito produzido por seu transporte pelo rio, principalmente como sedimento ativo de corrente, adquirem granulometria mais fina que originalmente, facilitando assim o seu transporte por suspensão e assimilação pela biota, no sistema aquático. 
A partir das diversas considerações e discussões aqui relatadas, verifica-se que as pilhas de resíduos de mineração e metalurgia constituem, ainda hoje, um problema para a preservação ambiental desta região por portarem metais com elevada toxicidade. Os rejeitos lançados no Rio Ribeira de Iguape, contendo elevados teores de metais pesados, em decorrência de suas características, estão interagindo com este ambiente.

\subsection{Sedimentos}

Depois de caracterizadas as fontes poluidoras foram levantadas as seguintes questões: 1) Estas fontes, ainda hoje, permanecem neste sistema aquático? 2) Qual dos sedimentos estaria interagindo com estas fontes? 3) Quais os locais preferenciais para esta deposição? 4) Qual fonte está contribuindo de fato, nesta poluição?

As respostas para estas perguntas foram apresentadas com os resultados analíticos obtidos para os sedimentos depositados em bancos de areia, ativo de corrente, suspensão e estuarinos, visto que os mesmos apresentaram teores representativos de metais pesados $(\mathrm{Pb}, \mathrm{Zn}$ e $\mathrm{Cu})$. Estes metais apresentaram teores mais baixos do que os relatados na literatura durante a época em que a empresa Plumbum S/A estava atuando (EYSINK, et al., 1988; TESSLER, et al., 1987). Esta diminuição nos teores dos metais pesados no Rio Ribeira de Iguape, depois da paralisação das atividades de mineração e beneficiamento do minério, também foi comprovada em trabalhos realizados com sedimentos de corrente (CASSIANO, 2001; LOPES Jr. 2005).

Dos sedimentos investigados, observou-se que os teores de $\mathrm{Pb}$ e $\mathrm{Zn}$ foram maiores nos depósitos em bancos de areia, principalmente no trecho de Iporanga até Eldorado. Estes valores podem estar refletindo os resíduos de mineração e metalurgia que foram lançados a montante deste percurso e que em decorrência das condições físico-quimicas, relevo e hidrologia deste sistema aquático, proporcionaram a deposição de tais materiais e conseqüentemente dos metais pesados, registrando desta forma a atividade poluidora pretérita que ocorreu neste rio.

Cabe ressaltar, que em cada ponto de coletada têm-se sedimentos com características diferenciadas (granulometria, teor de matéria orgânica, concentração de metais pesados, etc), decorrentes das diferentes condições energéticas existente neste rio. Como verificado na revisão bibliográfica, o Rio Ribeira de Iguape, a montante de Itaoca apresenta canal profundamente entalhado e encachoeirado, a partir deste ponto, um pouco a jusante de Eldorado, o rio passa a exibir padrão meandrante. Desta forma, os resultados analíticos apresentados para os sedimentos, são reflexos do ponto de amostragem, que pode estar contribuindo mais ou menos para deposição tanto de resíduos de mineração 
como de siderurgia portando metais potencialmente tóxicos, os quais dependem das condições encontradas neste local (energéticas, relevo, físico-químicas, dentre outras).

Os resultados das análises granulométricas e conteúdo de matéria orgânica para as amostras do trecho de Iporanga-Eldorado apontaram condições mais favoráveis para o depósito de metais pesados (granulometria mais fina e teor um pouco mais elevado de matéria orgânica). A concentração dos metais pesados nos sedimentos não depende somente das fontes antrópicas, mas também das características texturais, conteúdo de matéria orgânica, composição mineralógica e ambiente deposicional, como relatado por Presley et. al. (1980) apud BaHema-Manjarrez (2002).

Para os sedimentos depositados em bancos de areia não foi identificada variação lateral na composição química destes elementos o que permite excluir a necessidade de realizar várias coletas em um mesmo banco. Quanto à variação com a profundidade, está existe e depende do ponto amostrado, sugerindo a necessidade do estudo de perfis, nos bancos de areia.

Deve ser considerado que além dos pontos de amostragem, a época de coleta é muito importante, pois este sistema aquático acompanha de perto o regime pluvial. Desta forma, as maiores vazões são verificadas em janeiro e fevereiro, períodos de maior pluviosidade, com já visto anteriormente. Dependo da época de coleta, os teores de metais pesados detectados nos sedimentos, podem ser mais ou menos elevados. Na literatura consultada, também foi constatado, que em períodos de menor precipitação pluviométrica os valores de $\mathrm{pH}$ tendem a alcalinidade, devido ao enriquecimento de íons bicarbonatos nestes sistemas aquáticos contribuindo para um aumento nos valores de $\mathrm{pH}$. No caso aqui presente, as coletas ocorreram nos meses de menor pluviosidade, refletindo assim nos teores de metais pesados detectados nos diferentes sedimentos, pois neste período há o favorecimento da precipitação de metais pesados em virtude do aumento do $\mathrm{pH}$.

Os sedimentos coletados no sistema estuarino, (Ilha do Caranguejo - Mar Pequeno), também apresentaram concentrações mais elevadas para $\mathrm{Pb}, \mathrm{Zn}$ e $\mathrm{Cu}$ que os sedimentos em suspensão e os ativos de corrente. Nestes sedimentos, quanto maior a profundidade, maior os teores encontrados para estes metais pesados. Possivelmente, os metais pesados devem ter sido transportados pelos sedimentos em suspensão (adsorvidos), como também em solução até o sistema estuarino, onde em função de mudanças nas condições de pH e Eh, foram e estão sendo precipitados. A base do perfil coletado no sistema estuarino é mais enriquecida em metais pesados, o que deve ter sido favorecido, pelas características deste material, que nesta porção é mais fino e mais enriquecido em matéria orgânica, condições propicias para deposição de metais pesados. 
As análises químicas empregadas nos sedimentos ativos de corrente servem apenas como indicativo na comparação dos teores de metais pesados obtidos em diferentes ataques químicos realizados com este sedimento. Não servindo como analise detalhada de especiação química, pois o ataque realizado com os dois tipos de reagentes foi total, diferenciando apenas na destruição do reticulo cristalino. Nesta pesquisa, também foi comprovado que o trecho de Iporanga é o mais rico em $\mathrm{Pb}$ e $\mathrm{Zn}$.

Nos sedimentos em suspensão foram verificados valores mais elevados de $\mathrm{pH}$ na direção de Iporanga/Eldorado/Sete Barras e mais baixos em Iguape. $\mathrm{O}$ alto $\mathrm{pH}$ verificado em Iporanga é freqüentemente mencionado na literatura como resultado dos produtos do intemperismo e do embasamento de rochas carbonáticas pertencentes ao Grupo Açungui. É necessário lembrar que a Bacia Hidrográfica do Rio Ribeira de Iguape insere-se em terrenos geológicos diversos e não somente em locais com predomínio de rochas carbonáticas. Pelas análises realizadas, possivelmente estes teores, também podem ser reflexo da elevada quantidade de rejeito do concentrado (como comprovado, enriquecidos em $\mathrm{Ca}$ e $\mathrm{Mg}$ ) que foram lançados a montante deste ponto, neste rio, pois foi verificado na literatura que em sistemas aquáticos localizados em terrenos cársticos o pH não chega a atingir os valores obtidos na região do Alto Vale, o que não explica a hipótese de ser o embasamente o responsável por valores tão elevados de pH.

Os sedimentos em suspensão a partir de Registro, como comprovado pelas analises realizadas, já exibem características de sedimento estuarino, tanto com relação à composição química como pelos valores de pH e Eh, indicando que o Rio Ribeira de Iguape nesta porção já sofre influência das marés e conseqüentemente apresenta comportamento diferenciado com relação ao transporte e deposição dos metais pesados observados a montante deste local.

Os sedimentos em suspensão apresentaram associação com grãos de escória, indicando que o resíduo da metalurgia lançado pela Plumbum, deve ter sofrido cominuição pelo atrito entre as partículas transportadas pelo rio principalmente no cenário dos sedimentos ativos de corrente, permitindo assim ser carreado por uma longa distância. Esta constatação mostra influência direta dos resíduos com os sedimentos.

Os metais pesados não são permanentemente fixados nos sedimentos, podendo sofrer liberação para coluna d'água em decorrência de mudanças nas condições físicoquímicas do ambiente: $\mathrm{pH}$ e Eh. Neste trabalho, observa-se que há interação entre os metais pesados e os diferentes sedimentos aqui caracterizados e analisados, que dependendo das condições podem estar sendo liberados do banco de areia e conseqüentemente sofrendo mobilidade, ou por tração (sedimento de corrente) ou por 
suspensão, e sendo posteriormente depositados no sistema estuarino. Cabe ressaltar, que este sistema aquático deve ser constantemente monitorado, pois qualquer alteração neste meio, liberará os metais pesados aí depositados.

Além destes metais pesados, também foi detectado $\mathrm{Cr}$ em todos os tipos de sedimentos aqui analisados, tendo sua provável origem no material litológico do entorno da área, provenientes da Formação Água Clara que como anteriormente comentado, cobre cerca de 30\% da área da bacia. Conforme Reimann e Caritat (1998), os minerais hospedeiros de Cr são os piroxênios, anfibólios, micas, dentre outros. Estes aspectos acima mencionados podem explicar a existência de altos teores deste metal, principalmente, nos depósitos em bancos de areia e na porção magnética do sedimento em suspensão, que quando comparados com os valores de referência PEL/TEL do CCME (1999), ultrapassam estes dois limites para todos os pontos amostrados. Desta forma, entende-se que a origem deste metal é geogênica, mesmo não sendo este proveniente das atividades de mineração, é necessário monitoramento deste elemento neste sistema aquático, devido aos altos teores detectados.

Dos metais estudados, cuja proveniência está ligada à atividade de mineração, o Pb foi o único a exibir valor acima dos padrões de referência PEL/TEL, dependendo para tanto, do local de coleta e do tipo de sedimento. O Zn, na maioria dos sedimentos apresentou teores acima do background regional definido por CPRN (1978) e também acima do valor TEL do CCME (1999). Em todos os sedimentos, verificou-se comportamento químico similar para $\mathrm{Pb}$ e $\mathrm{Zn}$, tal fato é relatado com freqüência na literatura.

O teor elevado de Ba detectado nos sedimentos, possivelmente tem sua origem, nas rochas cuja mineralização é do tipo Perau, como também por influência dos rejeitos do concentrado da Plumbum, que como foram comprovados nesta pesquisa, estes são enriquecidos neste elemento. $\mathrm{O}$ teor de $\mathrm{Ba}$, nos sedimentos depositados em bancos de areia é mais elevado no trecho Iporanga-Eldorando, o que provavelmente comprova a hipótese aqui lançada, de que este elemento tenha sua origem nos rejeitos de mineração.

Com base nas diversas constatações aqui elencadas, as questões inicialmente apresentadas ganham as respectivas respostas: 1) Estas fontes ainda hoje permanecem neste sistema aquático; 2) Elas estão interagindo com todos os sedimentos, sendo que os teores variam conforme as características destes sedimentos. 3) Os locais preferenciais, constatados nas análises realizadas nos quatro tipos de sedimentos, apontam para o trecho de Iporanga, como sendo o preferencial para deposição dos metais pesados contidos nos resíduos e 4) Claramente nota-se a interação da escória juntamente com os sedimentos em suspensão, indicando que estes resíduos continuam sendo transportados pelo rio. Além de 
comprovada a interação dos sedimentos com a escória lançada no rio, também foi verificado, indiretamente, a contribuição do rejeito do concentrado nesta contaminação, inferida, principalmente, pelos teores de $\mathrm{Ba}, \mathrm{Ca}, \mathrm{Mg}, \mathrm{Pb}$ e $\mathrm{Zn}$ detectados nestes sedimentos, que aparentemente não devem ser computadas à uma origem natural.

\subsection{Biomonitores}

Para averiguar a biodisponibilidade dos metais pesados, bem como avaliar a possível depuração natural ou não deste sistema aquático, lançou-se a seguinte questão: Os resíduos lançados no Rio Ribeira de Iguape liberaram metais pesados para a biota?

Esta pergunta passa a ser respondida com a avaliação realizada em espécie biomonitora encontrada neste rio, molusco Asiático da espécie Corbicula fluminea. Os tecidos e as carapaças deste bivalve indicaram conteúdo de metais pesados provenientes das atividades de mineração realizadas no Alto Vale do Ribeira, os quais ultrapassaram valores detectados nesta mesma espécie em áreas não contaminadas.

Os resultados nos tecidos das Corbiculas flumineas exibiram a existência da disponibilidade química de $\mathrm{Pb}$ e $\mathrm{Cd}$ neste rio para estas espécies de bivalves. Estes metais pesados seguramente são provenientes da atividade de mineração que ocorreu por longo período nas proximidades deste rio. O Cd não foi detectado nos sedimentos, pois os equipamentos empregados não permitiram sua detecção.

Para todos os pontos de coleta o teor de Cd encontra-se abaixo do valor de referência da ANVISA, indicando assim que este metal pesado não está em concentrações capazes de contaminar este sistema aquático. Por outro lado, a média de $\mathrm{Pb}$ detectada nesta espécie biomonitora é maior que o recomendado pela ANVISA, principalmente para as amostras coletadas em Iporanga e Sete Barras.

Como identificado nas análises químicas realizadas nos sedimentos de banco de areia e sedimentos de corrente, os maiores teores de $\mathrm{Pb}$ detectados neste biomonitor, também se concentram em Iporanga. Este valor ultrapassou em 2,6 vezes o valor de referência da ANVISA para a concentração deste metal pesado em peixes e produtos de pesca para consumo. Tal fato demonstra claramente a interação dos resíduos que estão permanecendo neste trecho do rio com a biota aí existente. Indicando que estes bivalves estão acumulando este metal em seus tecidos, ou pela filtragem do material presente na coluna d'água (via respiração, estando este metal na forma dissolvida) ou a partir da alimentação dos materiais encontrados no leito do rio (via ingestão, sedimentos finos), sejam eles, resíduos da mineração ou resíduos da metalurgia. 
Com estes resultados, observou-se que concentrações aparentemente baixas nos sedimentos podem ser potencialmente disponibilizadas para acúmulo pelos organismos, tornando-se tóxicas. Assim sendo, nota-se que o Rio Ribeira de Iguape, ainda hoje, sofre os efeitos da poluição descontrolada realizada em outras épocas. Estes pontos permitem afirmar que em determinados locais há necessidade de monitoramento detalhado, quanto à interação dos contaminantes com a biota, uma vez que as comunidades ribeirinhas alimentam-se destes organismos, inclusive do bivalve aqui analisado.

Os teores de Cu e Zn detectados no presente estudo não são considerados tóxicos, sendo estes metais pesados considerados essenciais para vários sistemas enzimáticos presentes nestes organismos, além destes teores estarem em conformidade com os encontrados nestes bivalves em ambientes não contaminados.

Com os resultados obtidos nas análises das carapaças, levantou-se a seguinte hipótese: Se os rejeitos do concentrado contem Ca e Mg, depositados preferencialmente no trecho amostrado de Iporanga, então estes elementos estão sendo filtrados por estes bivalves para constituição de suas carapaças, e em assim sendo deve também estar ocorrendo precipitação de $\mathrm{Pb}$ e outros metais tóxicos presentes neste rejeito.

Como já mencionado, as comparações aqui realizadas com teores detectados em Corbiculas flumineas de outras localidades, bem como com outros bivalves de água doce, devem ser considerados apenas como uma referência, uma vez que se trata de ambientes diferentes com condições físico-químicas distintas e também, de espécies com tamanhos, peso e idades diferentes, as quais podem apresentar distintos índices de acúmulo dos metais pesados.

Resumidamente, verifica-se integração dos resíduos lançados no Rio Ribeira de Iguape e sua biodisponibilidade pela biota, principalmente no caso do $\mathrm{Pb}$ e $\mathrm{Cd}$, contidos nestes resíduos. Como já comentado tal fato é de extrema importância, uma vez que algumas comunidades ribeirinhas alimentam-se deste bivalve. 


\section{CONCLUSÕES}

Com base nos resultados obtidos e nas discussões aqui apresentadas pode-se aferir as seguintes conclusões:

1) Os rejeitos analisados são distintos entre si, facilitando assim a identificação destes nos sedimentos. O Rejeito do Rocha é constituído basicamente por $\mathrm{Ca}$ e Mg, conferindo assim, um caráter básico a este rejeito o que impede a formação de drenagem ácida. O Rejeito da Plumbum é rico em $\mathrm{Si}, \mathrm{Ba}$ e Fe. A presença de teores elevados de $\mathrm{Ba}$ confere uma particularidade que não foi observada para o rejeito do concentrado do Rocha e na escória. A escória exibiu altíssimo teor de $\mathrm{Zn}$ e $\mathrm{Pb}$, os quais não foram observados, nesta magnitude, para os outros dois resíduos da mineração,

2) O rejeito da mina do Rocha, a julgar pelos teores de $\mathrm{CaO}$ e $\mathrm{MgO}$, denota a filiação eminentemente carbonática do minério que alimentou a planta de concentração,

3) A usina Plumbum processou minérios de diversas fontes, incluindo as mineralizações do tipo "Perau", portadoras de barita. Os rejeitos da Plumbum apresentaram teores de carbonatos menores que os da mina do Rocha, conferindo assim, maior fragilidade deste depósito no tocante à possibilidade de liberação dos metais pesados nele contido e maior periculosidade ambiental ( $\mathrm{pH}$ é mais ácido), tendo em vista o volume dos rejeitos ali dispostos,

4) Os três resíduos aqui estudados exibiram valores de $\mathrm{Pb}$ acima da norma ABNT (NBR 10.005), classificando-os como resíduos sólidos pertencentes à "Classe I",

5) Dos resíduos analisados o rejeito do concentrado da Plumbum e as escórias são os mais problemáticos ambientalmente. O rejeito por apresentar granulometria fina, $\mathrm{pH}$ mais baixo, teores menores de $\mathrm{Ca}$, ter apresentado teor elevado no teste de lixiviação como preconizado na norma da ABNT (NBR 10.005) e por estar depositado próximo a margem do Rio Ribeira de Iguape. A escoria, por outro lado, é considerada também problemática ambientalmente, pois exibe teores elevados de $\mathrm{Pb}$ e $\mathrm{Zn}$, além de ser facilmente cominuida pelo atrito ao ser transportada pela drenagem e assim poder liberar os metais nela contidos para o meio ambiente, 
6) Parte importante de metais pesados como $\mathrm{Pb}, \mathrm{Cu}$ e $\mathrm{Zn}$, lançados como resíduos no Rio Ribeira de Iguape durante o período de beneficiamento e refino do minério na região do Alto Vale do Ribeira encontram-se depositados nos sedimentos,

7) Boa parte dos resíduos de mineração encontra-se depositada na porção mediana do curso do Ribeira (trecho Iporanga/ Sete Barras) comprovado pela existência de elevadas concentrações de $\mathrm{Ca}$ e $\mathrm{Mg}$ (rejeito da mina do Rocha). Além da comprovação de que tanto os tecidos como as carapaças do biomonitor encontram-se com elevada presença de $\mathrm{Pb}$ principalmente neste trecho.

8) Os elevados teores de $\mathrm{Ba}$ em algumas porções dos sedimentos amostrados sugerem vinculação direta com os rejeitos de mineração lançados no leito do Rio Ribeira de Iguape, muito provavelmente oriundos do tratamento na planta da Plumbum (rico em Ba),

9) Uma parcela destes metais está sendo mobilizada junto aos sedimentos em suspensão e migrando ao longo do curso do Rio Ribeira de Iguape, até a foz, sistema estuarino lagunar, comprovação esta obtida pela presença de escória nestes sedimentos e de teores elevados dos diversos metais aqui analisados,

10) Alguns destes metais encontram-se com teores de referência que merecem monitoramento e atenção (valores PEL e TEL) nestes quatro tipos de sedimentos como demonstrado, mesmo não sendo adequado em alguns casos o uso deste valor de referência,

11) A pesquisa realizada nos sedimentos depositados em bancos de areia na junção do rio Juquiá com o rio Ribeira comprova, que os metais pesados detectados no Ribeira são provenientes das atividades de mineração realizadas nas cabeceiras deste rio, e que possivelmente, o $\mathrm{Cr}$ não é oriundo de tal atividade, e sim de unidades litológicas de afinidade deste elemento contidas na estrutura estratigráfica que compõem o vale do Ribeira, uma vez que as análises dos sedimentos do Juquiá só exibiram teores de Cr;

12) O surgimento do metal $\mathrm{Cr}$ nos sedimentos pode ser creditado a uma origem geogênica. No entanto, suas concentrações com base nos valores de referência PEL e TEL são dignos de monitoramento, não só como quanto a sua origem como quanto ao seu modo de existência química nos sedimentos,

13) Atenção especial deve ser dada aos sedimentos em suspensão, visto que estes, ao que tudo indica, representam o veículo de deslocamentos a partir do curso médio 
do Rio Ribeira de Iguape de diversos metais (tóxicos ou não) residentes no leito desta drenagem, inclusive da escória, como ficou demonstrado nas análises químicas e em MEV/EDS,

14) A presença do $\mathrm{Cr}, \mathrm{Cu}, \mathrm{Pb}$ e $\mathrm{Zn}$ nas amostras de sedimento estuarino, coletadas na ilha do Caranguejo - Mar Pequeno - a sul de Iguape, confirmam a migração dos poluentes da região do Alto Vale para a foz, esta migração, como verificado pelas análises nos sedimentos em suspensão, está sendo realizada a partir do material em suspensão,

15) A existência de um biomonitor "exótico" e marcador permite seu uso como base de referência da qualidade dos sedimentos depositados ao longo do curso do Rio Ribeira de Iguape,

16) Pode-se concluir que parte do Rio Ribeira, principalmente nas localidades próximas das minas, ainda hoje, encontra-se contaminado, pois as análises realizadas em tecidos do biomonitor analisados (Corbicula fluminea) indicaram valores de $\mathrm{Zn}, \mathrm{Pb}, \mathrm{Cd}, \mathrm{Cu}$ e $\mathrm{Cr}$. Os valores de $\mathrm{Pb}$ foram mais elevados que os detectados em estudos realizados em outros rios com problemas de contaminação (valores de referência), principalmente para as amostras de Iporanga e Sete Barras,

17) De modo geral, a região de Iporanga é a mais comprometida, pois todas as análises realizadas em diferentes materiais indicaram os maiores teores para metais pesados, o que possivelmente deve estar indicando maior deposição dos resíduos neste trecho. Outro ponto, para explicar os maiores teores em Iporanga, possivelmente deve-se a diluição dos metais pesados ao longo do rio, em função da recarga de drenagens tributárias, frequentemente menor portadoras de metais potencialmente tóxicos,

18) A despeito de diversas posições contrárias a esta afirmação, verifica-se que o Rio Ribeira não está sofrendo processos naturais de depuração. Mesmo considerando os valores minimizados dos metais analisados em sedimentos quando comparados com dos diversos rejeitos, estes persistem no sistema aquático, e interagem com a biota, indicando biodisponibidade. O biomonitor aqui estudado representa $01^{\circ}$ nível trófico na cadeia alimentar, tal fato indica a necessidade de estudos detalhados em outros organismos, pois pode estar ocorrendo a biomagnificação destes metais neste sistema. Além disso, estes bivalves são consumidos por algumas comunidades ribeirinhas. 


\section{Processos De ReMEDiAÇÕes}

As caracterizações físico-químicas, tanto dos resíduos de mineração como dos sedimentos do Rio Ribeira de Iguape, bem como as análises realizadas nos tecidos e carapaças de biomonitores, induziram as seguintes propostas de reabilitação ou pelo menos de minimização da contaminação neste rio:

1) Propor a reimplantação das matas ciliares onde elas foram degradadas, com faixa conforme estabelece a lei de mananciais, evitando-se assim, perturbações nos materiais depositados nas bordas do rio, pois caso contrário, haverá aumento na carga de materiais em suspensão. O aumento desta carga acarretará em maior liberação de metais pesados que já estão depositados, contribuindo para a concentração de maiores teores na foz do rio e na biota;

2) Procurar ser mantida as condições de valores de $\mathrm{pH}$ tendendo a alcalinidade, visto que estas condições permitem maior permanência de metais pesados precipitados. Estes metais nesta condição de pH não são facilmente solubilizados. Sendo mantidas tais condições, diminui-se o risco de maior mobilidade de metais pesados nesta drenagem; Desta forma devem ser controladas as diversas atividades mineiras na drenagem (Extrações de areia, por exemplo) e ter-se um controle sobre a entrada de descargas de outras origens, tanto no próprio canal do Rio Ribeira como de afluentes que nele se inserem (por exemplo, o Rio Juquia)

3) Com referencia a prática de extração de areia, esta deve ser controlada principalmente nas áreas aqui diagnosticas com teores mais elevados de metais pesados, ou seja, nas proximidades de Iporanga e Eldorado, pois esta atividade promove a perturbação nos sedimentos de fundo causando a ressuspensão destes e provocando a liberação e disponibilidade do metal para coluna d'àgua e para a biota, como foi observado com os bivalves coletados nesta área;

4) Evitar e ou manter controle sobre a entrada de esgoto nas drenagens, promovida pelo despejo das concentrações urbanas localizadas próximas ao rio (Iporanga, Eldorado e Sete Barras), pois tal processo pode acarretar acidulação da água e conseqüentemente alteração no pH acompanhado da maior disponibilidade dos metais pesados na forma de eletrólitos. 
5) Monitorar os resíduos de mineração e metalurgia depositados nas proximidades do Rio Ribeira de Iguape em Adrianópolis, pois como foi aqui observado, estes resíduos podem ser facilmente transportados pelo vento, devido a granulometria, e serem incorporados no sistema aquático ou no solo. Sendo necessária medidas de recuperação ambiental, nestas áreas; 


\section{REFERÊNCIA BIBLIOGRÁFICA}

ABAYCHI, J. K.; MUSTAFÁ, Y. Z. The asiatic clam Corbicula fluminea: an indicator of trace metal pollution in the Shatt al-Arab river, Iraque. Environmental Pollution, Elsevier, v.54, p. 109-122. 1988.

ALMEIDA, F. F. M. Fundamentos geológicos do relevo paulista. Boletim do Instituto Geográfico e Geológico, São Paulo, IGC, v.41, p.169-263, 1964.

ANJOS, J. A. S. A. Estratégias para remediação de um sítio contaminado por metais pesados - estudo de caso. São Paulo, 1998. 157p. Dissertação de Mestrado - Escola Politécnica da Universidade de São Paulo. Departamento de Engenharia de Minas. São Paulo. 1998.

ANVISA - AGÊNCIA NACIONAL DE VIGILÂNCIA SANITÁRIA. Portaria n685/98. Princípios gerais para o estabelecimento de níveis máximos de contaminantes químicos em alimentos. Limites máximos de tolerância para contaminantes inorgânicos. 1998. Ministério da Saúde. Secretária de Vigilância Sanitária. Disponível em: http://elegis.anvisa.gov.br/leisref/public/showAct.php?id=90. Acessado em: fevereiro de 2007.

ASSOCIAÇÃO BRASILEIRA DE NORMAS TÉCNICAS - ABNT. NBR10004 - Resíduos Sólidos. Rio de Janeiro: ABNT, 1987a. 48p.

ASSOCIAÇÃO BRASILEIRA DE NORMAS TÉCNICAS - ABNT. NBR10005 - Lixiviação de Resíduos - Procedimento. Rio de Janeiro: ABNT, 1987b. 7p.

ASSOCIAÇÃO BRASILEIRA DE NORMAS TÉCNICAS - ABNT. NBR10006 - Solubilização de Resíduos - Procedimento. Rio de Janeiro: ABNT, 1987c. 2p.

BaHENA-MANJARREZ, J. L., ROSALES-HOZ, L., CARRANZA-EDWARDS, A., Spatial and temporal variation of heavy metals in a tropical estuary. Environmental Geology. v. 42, p.575-582, 2002.

BAUDO, R.; GIESY, J. P.; MUNTAU, H. Sediments: chemistry and toxicity of in place pollutants. Lewis Publishers, Boston, Boca Raton, 1990, 405p.

BELANGER, S. F.; FARRIS, J. L.; CHERRY, D. S.; CAIRNS, J. JR. Validation of Corbicula growth reductions induced by cooper in artificial streams and natural rivers. Canadian Journal of Fisheries. v.47. p.904-914. 1990.

BILOS, C.; COLOMBO, J. C.; PRESA, M. J. R. Trace metals in suspended particles, sediments and asiatic clams (Corbicula fluminea) of the rio de la Plata Estuary, Argentina. Environmental Pollution. Elsevier. v.99. p.1-11. 1998.

BOSSO, S. T.; ENZWEILER, J. Avaliação da biodisponibilidade de chumbo em solos superficiais, minerais e rejeitos de minério do município de Adrianópolis (PR-Brasil). In: IX CONGRESSO BRASILAEIRO DE GEOQUÍMICA - BELÉM-PA. 2003. Livro Resumo. 2003. p.8-10. 
BOURG, A. C. M. Speciation of heavy metals in soils and groundwater and implications for their natural and provoked mobility. In: SALOMONS, W.; FÖRSTNER, U. MADER, P. (eds.) Heavy metals: problems and solutions, New York, Springer Verlag. 1995. p.19-31.

CANADIAN COUNCIL OF MINISTERS OF THE ENVIRONMENT - CCME. Canadian sediment quality guidelines for the protection of aquatic life. 1999. Disponível em:<http://www.ccme.ca/publications/can_guidelines.html>. Acesso em: 02 Jul. 2003.

CAPELLOZZA, A. N. Estudo da decomposição mineral e evolução geoquímica de uma pilha de rejeitos de minério da mina de chumbo de Panelas, Vale do Ribeira - SP. 2006. 51p. Monografia de Trabalho de Formatura, Instituto de Geociências, Universidade de São Paulo. São Paulo. 2006.

CASSIANO, A. M. Estudo da contaminação por metais na bacia do rio Ribeira de Iguape (SP-PR): estratégias para a remediação da área de disposição de rejeitos da mina do Rocha. 2001. 159p. Tese de Doutorado, Escola de Engenharia de São Carlos, Universidade de São Paulo, São Carlos, 2001.

CENTRO TECNOLÓGICO DA FUNDAÇÃO PAULISTA DE TECNOLOGIA E EDUCAÇÃO. CETEC. Situação dos recursos hídricos do Ribeira de lguape e Litoral Sul. São Paulo: CETEC, 1999. 213p.

CIDU, R.; CABOI, R.; FANFANI, L.; FRAU, F. Acid drainage from sulfides hosting gold mineralization (Furtei, Sardinia). Environmental Geology. Springer-Verlag. v. 30, n.3/4, 1997, p.230-237.

COMPANHIA DE TECNOLOGIA DE SANEAMENTO AMBIENTAL - CETESB. Avaliação dos níveis de contaminação por metais pesados e pesticidas organoclorados na água, ictiofauna e outros organismos aquáticos do complexo Estuarino - Lagunar de IguapeCananéia: São Paulo: CETESB. 1986. Relatório Final. 68p.

COMPANHIA DE TECNOLOGIA DE SANEAMENTO AMBIENTAL - CETESB. Indicadores da qualidade ambiental do Rio Ribeira de lguape: considerações preliminares. São Paulo. CETESB. 1991. Normalização Técnica. 33p.

CORSI, A. C. Estudo da dispersão de metais pesados em águas e sedimentos de corrente a partir de mineralizações de chumbo-zinco-prata: o exemplo das jazidas Canoas, Perau e Barrinha (Vale do Ribeira, PR). 1999. 139p. Dissertação de Mestrado, Instituto de Geociências e Ciências Exatas, Universidade Estadual Paulista, Rio Claro, 1999.

CORSI, A. C.; LANDIM, P. M. B. Chumbo, zinco e cobre em sedimentos de corrente nos Ribeirões Grande, Perau e Canoas, e córrego Barrinha no município de adrianópolis (Vale do Ribeira) SP. Geociências. Unesp. v.22, Nº especial, São paulo, p49-61, 2003.

CPRN - Coordenadoria de Proteção dos Recursos Naturais. Relatório técnico: Projeto geoquímico no vale do Ribeira - Relatório final. São Paulo. 326p. 1978

CUNHA, F. G. Contaminação humana e ambiental por chumbo no Vale do Ribeira, nos estados de São Paulo e Paraná, Brasil. 2003. 111p. Tese de Doutorado, Instituto de Geociências, Universidade Estadual de Campinas, Campinas, 2003. 
CUNHA, F. C.; PAOLIELLO, M. M. B.; FIGUEIREDO, B. R.; CAPITANI, E. M. Contaminação humana e ambiental por chumbo em Adrianópolis, no alto Vale do Ribeira, no estado do Paraná, Brasil. In: IX CONGRESSO BRASILAEIRO DE GEOQUÍMICA - BELÉM-PA. 2003. Livro Resumo. 2003. p.68-69.

CZARNEZKI, J. M. Use of pochetbook mussels Lampsilis ventricosa, for monitoring heavy metal pollution in an Ozark stream. Bulletim of Environmental Contamination and Toxicology, v.38, p.641-646, 1987.

DAITX, E. C. Origem e evolução dos depósitos sulfetados tipo-perau (Pb-Zn-Ag), com base nas jazidas Canoas e Perau (Vale do Ribeira, PR). 1996. 453p. Tese de Doutorado Instituto de Geociências e Ciências Exatas - Universidade Estadual Paulista. Rio Claro, 1996.

DEPARTAMENTO DE ÁGUAS E ENERGIA ELÉTRICA. DAEE. Plano de ação para o controle das inundações e diretrizes para o desenvolvimento do Vale: In: Revista Água e Energia, São $\quad$ Paulo. $1999 . \quad$ Disponível em: $<$ http://www.daee.sp.gov.br/acervopesquisa/relatorios/revista/raee9904/ribeira_do_iguap e.htm>. Acesso em: 20 de junho de 2006.

DEPARTAMENTO DE ÁGUAS E ENERGIA ELÉTRICA - DAEE. Banco de dados pluviométricos do estado de São Paulo. São Paulo. 2006. Disponível em: <http://www.sigrh.sp.gov.br/cgi-bin/bdhm.exe/flu> Acesso em: 02 de agosto de 2006.

DEPARTAMENTO DE ESTRADAS DE RODAGEM. DER. Mapa rodoviário do estado de São Paulo - Eldorado/Cerro Azul. São Paulo, 2006. Disponível em: <http://www.der.sp.gov.br/mapa_rodoviario/default.asp> Acesso em: 22 de maio de 2006.

EYSINK, G. G.; PÁdUA, H. B.; BERTOLETTI, S. A. E. P.; COIMBRA-MARTINS, M.; NAVAS-PEREIRA, D.; ROBERTO, S. Metais pesados no Vale do Ribeira e IguapeCananéia. Ambiente. São Paulo. v.2. p.6-13. 1988.

EYSINK, G. G.; COIMBRA-MARTINS, M.; VARGAS-BOLDRINI, C.; NAVAS-PEREIRA, D. Metais pesados em organismos aquáticos do rio Ribeira de Iguape e do complexo Estuarino-Lagunar de Iguape-Cananéia: avaliação preliminar. In: SIMPÓSIO DE ECOSSISTEMAS DA COSTA SUL E SUDESTE BRASILEIRA: ESTRUTURA, FUNÇÃO E MANEJO, Águas de Lindóia. Anais. Águas de Lindóia: ACIESP, 1990. v.2, p. 417-443.

FERREIRA, J. C. G. Aspectos da geoquímica ambiental da Mina do Rocha - PR. 1994. 94p. Dissertação de Mestrado, Instituto de Geociências, Universidade de São Paulo, São Paulo, 1994.

FIGUEIREDO, B. R. (2005) Contaminação ambiental e humana por chumbo no Vale do Ribeira (SP-PR).

Disponível

em: $<$ http://www.comciencia.br/reportagem/2005/11/09.shtml>. Acesso em 05 de agosto de 2006.

FLEISCHER, R. A. A pesquisa de chumbo no Brasil. In: CONGRESSO BRASILEIRO DE GEOLOGIA. 29. 1976. Ouro Preto. Anais. Ouro Preto: SBG, 1976. v.1, p.19-32. 
FRANCHI, J. G. A utilização de turfa como adsorvente de metais pesados. O exemplo da contaminação da bacia do rio Ribeira de lguape por chumbo e metais associados. 2004. 187p. Tese de Doutorado, Instituto de Geociências, Universidade de São Paulo, São Paulo, 2004.

FRANCHI, J. G.; SÍGOLO, J. B.; MACEDO, A. B.; GUIMARÃES, V.; VIEIRA, M. S. Redistribuição de elementos maiores e metais associados em perfil de rejeito de mineração de chumbo - Vale do Ribeira - SP/PR. In: CONGRESSO BRASILEIRO DE GEOLOGIA, 41, 2002, João Pessoa. Anais João Pessoa: SBG, 2002, p. 237.

GRANEY, Jr. R. L.; CHERRY, D. S.; CAIRNS, Jr. J. The influence of substrate, pH, diet and temperatura upon cadmium accumulation in the asiatic clam (Corbicula fluminea) in laboratory artificial streams. Water Res. Great Britain. v.18, n.7, p.833-842. 1984.

GUIMARÃES, V. Distribuição de metais pesados provenientes dos resíduos de lodo de esgoto em ambiente lacustre. 2001. 111p. Dissertação de Mestrado, Instituto de Geociências, Universidade de São Paulo. São Paulo. 2001.

GUIMARÃES. V.; SíGOLO, J. B. Metais pesados em sedimentos aluvionares e em moluscos asiáticos (Corbicula fluminea) - Rio Ribeira de Iguape - Brasil. In: XIV SEMANA DE GEOQUÍMICA \& VIII CONGRESSO DOS PAÍSES DE LÍNGUA PORTUGUESA, 2005, Aveiro. Portugal. Anais. Aveiro. v.2. p.509-512.

HAKANSON, L., JANSSON, M. Principles of lake sedimentology. Berlin, Springer Verlag, Heidelberg, 1983, 316p.

HAKENKAMP, C. C.; PALMER, M. A. Introduced bivalves in freshwater ecosystems: the impact of Corbicula on organic matter dynamics in a sandy stream. Oecologia. SpringerVerlag. v.119. p.445-451. 1999.

JACOMINI, A. E. Bioacumulação do herbicida atrazina pelas espécies de bivalves limnicos Anodontites trapesialis (Lamark, 1819) e Corbicula fluminea (1774). 2002. 89p. Dissertação de Mestrado, Faculdade de Filosofia, Ciências e Letras de Ribeirão Preto, Universidade de São Paulo. 2002.

KELLY, M. Mining and the Freshwater Environmental. Springer-Verlag. London. Elsevier. 231p. 1988.

KWONG, Y. T. J.; ROOTS, C. F.; ROACH, P.; KETTLEY, W. Post-mine metal transport and attenuation in the Keno Hill Mining District, Central Yukon, Canada, Environmental Geology. Springer-Verlag. v. 30, n.1/2, 1997. p.98-107.

LAROCQUE, A. C. L.; RASMUSSEN, P. E. An overview of trave metals in the environment, from mobilization to remediation. Environmental Geology. Springer-Verlag, v.33, n.2/3, p.85-91. 1998.

LEAL , P. R. M.; OLIVEIRA, M. C. B.; SÍGOLO, J. B. Decomposição mineral em perfil de rejeito de mineração de chumbo. In: SEMINÁRIO DE DESENVOLVIMENTO SUSTENTÁVEL E A RECICLAGEM NA CONSTRUÇÃO CIVIL, 5. 2002. São Paulo. Atas São Paulo: IBRACON, 2002. p.315-326. 
LEAL, P. M. Degradação mineral e granulométrica de uma pilha de rejeitos de mineração de chumbo do Vale do Ribeira - PR. 2002. 48p. Monografia de Trabalho de Formatura Instituto de Geociências, Universidade de São Paulo. São Paulo. 2002.

LOPES, Jr. I.; ENZWEILER, J.; VENDEMIATTO, M. A.; FIGUEIREDO, B. R. Mapeamento geoquímico de baixa densidade do Vale do Ribeira (PR-SP) - chumbo, arsênio e metais associados em sedimentos de corrente. XLII CONGRESSO BRASILEIRO DE GEOLOGIA EXPOGEO. 2004. Araxá - MG. Anais. Araxá. CD.

LOPES, Jr., I. Atlas geoquímico do Vale do Ribeira: geoquímica dos sedimentos ativos de corrente. São Paulo. CPRM, 2005, 77p.

McCAULOU, T.; MATTER, W. J.; MAUGHAN, E. Corbiculae Fluminea as a bioindicator on the lower Colorado river. $1994 . \quad$ Disponível em: $<$ http://orion.cr.usgs.gov/dec_reports/115/report.html>. Acesso em: 13 de março de 2006.

MOLISANI, M. M.; SALOMÃO, M. S. M. B.; OVALLE, A. R. C.; REZENDE, C. E.; LACERDA, L. D.; CARVALHO, C. E. V. Heavy metals in sediments of the lower Paraíba do Sul river and estuary, RJ, Brazil. Bulletin of Environmental Contamination and Toxicology. New York. Springer-Verlag. v.63, p.682-690, 1999.

MOORE, J. W.; RAMAMOORTHY, S. Heavy metals in natural waters. First Edition. New York, Springer Verlag, 1984, 267p.

MORAES, R. P. Transporte de chumbo e metais associados no Rio Ribeira de Iguape, São Paulo. 1997. 94p. Dissertação de Mestrado, Instituto de Geociências, Universidade Estadual de Campinas, Campinas, 1997.

MORAES, R. P.; FIGEUIREDO, B. R.; LAFON, J. M. Pb-isotopic tracing of metal-pollution sources in the Ribeira Valley, southeastern Brazil, Terrae, Campinas. v.1., n.1, p.19-26, 2004.

PHILLIPS, D. J. H. The use of biological indicator organisms to monitor trace metal pollution in marine and estuarine environmentas - a review. Environmental Pollution. v.13. p.282317, 1977.

REIMANN C.; CARITAT P. Chemical elements in the environment: factsheets for the geochemist and environmental scientist. First Edition. Heidelberg. Springer Verlag. 1998. $398 p$.

RODGERS, J. H. Jr., CHERRY, D. S.; GRANEY, R. L.; DIKSON, K. L.; CAIRNS, J. JR. Comparison of heavy metal interactions in acute and artificial stream biossay techniques for the Asiatic clam (Corbicula fluminea). In: Eaton, J. G., Parrish, P. R.; Hendricks, A. C. Aquatic Toxicology, ASTM STP 707. American Society of Testing and Materials, Philadelphia, p.266-280. 1980.

ROON, V. M. Availability, Toxicity and uptake of heavy metals by marine invertebrates - a review with reference to the Manukau Harbour, New Zealand. 1999. Department of 
Planning Working Paper Series. Auckland, New Zealand. Disponível em: $<$ http://www.planning.auckland.ac.nz>. Acessado em: março de 2006.

RYBICKA, E. H. Impact of mining and metallurgical industries on the environment in Poland. Applied Geochemistry. Elsevier Science, Great Britain, v.11, p.3-9. 1996.

SALOMONS, W. Environmental impact of metals derived from mining actives: processes, predictions, prevention. Journal of Geochimichal Exploration, Elsevier, n.52, p.5-23, 1995.

SALOMONS, W.; STIGLIANI, W. M. Biogeodynamics of pollutants in soils and sediments. Berlin, Springer Verlag, Heidelberg, 1995. p.87-100.

SANTOS A. R.; MELO, G. Jr.; GUIMARÃES, J. E. A. S. Concentração de metais pesados em frações granulométricas de sedimentos de fundo do rio Pitimbu, Região Sul da Grande Natal (RN): implicações para levantamentos ambientais. Revista de Geologia, v. 15, p.01-08, 2002.

SECRETARIA DO ESTADO DO MEIO AMBIENTE - SÃO PAULO (ESTADO) Programa de educação ambiental do Vale do Ribeira. 2 ed. São Paulo. Secretaria do Meio Ambiente e Secretaria da Educação, 1992, p.129-223.

SHI, B.; ALLEN, H. E.; GRASSI, M. T.; HUIZHONG, M. Modeling cooper partitioning in surface waters. Water Resource, v. 32, p. 3756-3764, 1998.

SÍGOLO, J.B.; GUIMARÃES, V.; FRANCHI, J. G.; CEREGATTI, A. R. O. Metais pesados em sedimentos ativos de corrente do rio Ribeira de Iguape (SP). Implicações ambientais. In: IX CONGRESSO BRASILAEIRO DE GEOQUÍMICA - BELÉM/PA. 2003. Livro Resumo. 2003. p.548-550.

SILVA, R. H. P. Geoquímica do arsênio e impacto ambiental no Vale do Ribeira (SP-PR): área de metalogênese. 1997. 100p. Dissertação de Mestrado, Instituto de Geociências, Universidade Estadual de Campinas, Campinas, 1997.

TASSINARI, C. C. G.; BARBOUR, A. P.; DAITX, E. C.; SATO, K. Aplicação de isótopos de $\mathrm{Pb}$ e $\mathrm{Sr}$ na determinação da natureza das fontes das mineralizações de chumbo do Vale do Ribeira, SP e Pr. CONGRESSO BRASILEIRO DE GEOLOGIA, 34, 1990, Natal, Anais, Natal: SBG, v.3, p.1254-1266.

TEÓDULO, M. J. R.; LIMA, E. S.; NEUMANN, V. H. M. L; LEITE, P. R. B.; SANTOPS, M. L. F. Comparação de métodos de extração parcial de metais traço em solos e sedimentos de um estuário tropical sob a influência de um complexo industrial portuário, Pernambuco, Brasil. Estudos Geológicos. v.13. p.23-34. 2003.

TESSIER, A., CAMPBELL, P. G. C., AUCLAIR, J. C., BISSON, M. Relationships between the partitioning of trace metals in sediments and their accumulation in the tissues of the freshwater mollusc Elliptio complanata in a mining area. Canadian Journal of Fisheries and Aquatic Sciences, v. 41, p.1463-1472. 1984. 
TESSLER, M. G.; SUGUIO, K.; ROBIOLOTTA, P. R. Teores de alguns elementos traços metálicos em sedimentos pelíticos da superfície de fundo da região lagunar de Cananéia - Iguape. In: SIMPÓSIO SOBRE ECOSSISTEMAS DA COSTA SUL E SUDESTE BRASILEIRA: SÍNTESE DOS CONHECIMENTOS. CANANÉIA. 1987. São Paulo. Anais. São Paulo. ACIESP. v.2, p.255-263.

TESSLER, M. G. Taxas de sedimentação holocênica na plataforma continental sul do estado de São Paulo. 2001. 155p. Tese de Livre-Docência, Instituto Oceonográfico, Universidade de São Paulo, São Paulo, 2001.

TOMAZELLI, A. C. Estudo comparativo das concentrações de $\mathrm{Cd}, \mathrm{Pb}$ e $\mathrm{Hg}$ em seis bacias hidrográficas do estado de São Paulo. 2003. 124p. Tese de Doutorado, Faculdade de Filosofia, Ciências e Letras de Ribeirão Preto, Universidade de São Paulo. Ribeirão Preto. 2003.

WAGNER, A.; BOMAN, J. Biomonitoring of trace elements in vietnamese freshwater mussels. Spectrochimica Acta Part B. Elsevier. v.59. p.1125-1132. 2003. 
Anexos 
$\begin{array}{lllllllllllllllllllll}\text { Amostra } & \mathrm{SiO}_{2} & \mathrm{Al}_{2} \mathrm{O}_{3} & \mathrm{MnO} & \mathrm{MgO} & \mathrm{CaO} & \mathrm{Na}_{2} \mathrm{O} & \mathrm{K}_{2} \mathrm{O} & \mathrm{TiO}_{2} & \mathrm{P}_{2} \mathrm{O}_{5} & \mathrm{SO}_{3} & \mathrm{Fe}_{2} \mathrm{O}_{3} & \mathrm{Cr}_{2} \mathrm{O}_{3} & \mathrm{BaO} & \mathrm{ZnO} & \mathrm{PbO} & \mathrm{Outros} & \mathrm{PF} & \mathrm{Fechamento}\end{array}$ Profundidade

\begin{tabular}{|c|c|c|c|c|c|c|c|c|c|c|c|c|c|c|c|c|c|c|}
\hline IE01 $(0-0,25 m)$ & 76,40 & 9,56 & 0,11 & 1,31 & 1,32 & 1,26 & 3,04 & 1,33 & 0,11 & 0,03 & 5,26 & 0,05 & 0,11 & 0,01 & 0,02 & 0,09 & 0,70 & 100,71 \\
\hline IE02 (0-0,20m) & 78,80 & 8,68 & 0,10 & 1,08 & 1,16 & 1,33 & 3,05 & 1,13 & 0,09 & 0,02 & 4,32 & 0,06 & 0,12 & $\overline{0,02}$ & $\overline{0,02}$ & 0,06 & 0,50 & 100,54 \\
\hline IE02 $(0,20-0,40 \mathrm{~m})$ & 79,50 & 8,91 & 0,09 & 1,04 & 1,02 & 1,37 & 3,17 & $\mathbf{0 , 8 0}$ & 0,10 & $<<$ & 3,75 & 0,06 & 0,12 & 0,02 & 0,02 & 0,07 & 0,52 & 100,56 \\
\hline IE02 $(0,40-0,60 \mathrm{~m})$ & 79,10 & 8,22 & 0,10 & 1,05 & 1,12 & 1,32 & 2,78 & 1,14 & 0,09 & 0,02 & 4,77 & 0,10 & 0,11 & 0,02 & 0,01 & 0,07 & 0,48 & 100,50 \\
\hline IE03 (0-0,20m) & 78,00 & 9,14 & 0,12 & 1,13 & 1,21 & 1,43 & 3,08 & 1,13 & 0,10 & 0,02 & 4,39 & 0,08 & 0,11 & 0,01 & 0,01 & 0,06 & 0,40 & 100,42 \\
\hline IE03 $(0,20-0,40 \mathrm{~m})$ & 77,40 & 9,27 & 0,10 & 1,19 & 1,24 & 1,34 & 3,10 & 1,26 & 0,11 & 0,02 & 4,69 & 0,04 & 0,13 & 0,02 & 0,02 & 0,07 & 0,59 & 100,59 \\
\hline IE03 $(0,40-0,56 \mathrm{~m})$ & 79,90 & 8,42 & 0,09 & 1,00 & 1,04 & 1,37 & 3,10 & 0,89 & 0,09 & $<<$ & 3,78 & 0,08 & 0,11 & 0,02 & 0,02 & 0,06 & 0,79 & 100,76 \\
\hline IE04 (0-0,20m) & 80,60 & 8,03 & 0,07 & 0,87 & 0,97 & 1,40 & 3,07 & 0,85 & 0,08 & $<<$ & 3,72 & 0,06 & 0,14 & 0,02 & 0,02 & 0,06 & 0,50 & 100,46 \\
\hline IE04 (0,20-0,40m) & 82,70 & 7,89 & 0,09 & 0,59 & 0,72 & 1,42 & 3,47 & 0,37 & 0,07 & $<<$ & 2,43 & 0,06 & 0,13 & 0,01 & 0,02 & 0,06 & 0,48 & 100,51 \\
\hline IE04(0,40-0,60m) & 82,90 & 7,67 & 0,08 & 0,58 & 0,71 & 1,43 & 3,33 & 0,41 & $\mathbf{0 , 0 7}$ & Nd & 2,53 & 0,07 & 0,16 & 0,02 & 0,01 & 0,06 & 0,45 & 100,48 \\
\hline IE04(0,60-0,80m) & 83,10 & 7,48 & 0,07 & 0,60 & 0,74 & 1,34 & 3,16 & 0,48 & 0,07 & Nd & 2,70 & 0,07 & 0,12 & 0,02 & 0,01 & 0,06 & 0,52 & 100,54 \\
\hline IE04(0,80-1,0m) & 81,20 & 7,64 & 0,09 & 0,68 & 0,86 & 1,34 & 3,15 & 0,87 & 0,08 & 0,02 & 3,81 & 0,07 & 0,14 & 0,01 & 0,02 & 0,07 & 0,64 & 100,69 \\
\hline IE04(1,0-1,2m) & 82,10 & 7,93 & 0,08 & 0,66 & 0,76 & 1,40 & 3,36 & 0,50 & $\mathbf{0 , 0 7}$ & $<<$ & 2,81 & 0,06 & 0,14 & 0,02 & 0,01 & 0,06 & 0,76 & 100,72 \\
\hline IE04(1,2-1,4m) & 81,50 & 8,09 & 0,08 & 0,73 & 0,83 & 1,43 & 3,22 & 0,65 & 0,08 & $<<$ & 3,09 & 0,07 & 0,12 & 0,02 & 0,02 & 0,06 & 0,52 & 100,51 \\
\hline $\operatorname{IE04}(1,4-1,6 m)$ & 81,40 & 7,84 & 0,07 & 0,80 & 0,95 & 1,34 & 3,12 & 0,76 & 0,08 & 0,02 & 3,32 & 0,05 & 0,13 & 0,02 & 0,02 & 0,06 & 0,48 & 100,46 \\
\hline IE04(1,6-1,8m) & 81,90 & 7,76 & 0,08 & 0,73 & 0,82 & 1,36 & 3,14 & 0,65 & $\mathbf{0 , 0 7}$ & $<<$ & 3,22 & 0,07 & 0,13 & 0,02 & 0,02 & 0,06 & 0,60 & 100,63 \\
\hline IE04(1,8-2,0m) & 82,00 & 7,83 & 0,08 & 0,76 & 0,86 & 1,33 & 3,14 & 0,61 & 0,08 & Nd & 3,09 & 0,06 & 0,12 & 0,02 & 0,02 & 0,06 & 0,57 & 100,63 \\
\hline $\operatorname{IE04}(2,0-2,2 \mathrm{~m})$ & 81,60 & 8,16 & 0,08 & 0,74 & 0,85 & 1,38 & 3,37 & 0,57 & 0,08 & $<<$ & 2,92 & 0,06 & 0,12 & 0,02 & 0,02 & 0,07 & 0,63 & 100,67 \\
\hline IE04(2,2-2,4m) & 81,20 & 8,63 & 0,08 & 0,76 & 0,77 & 1,48 & 3,50 & 0,49 & 0,09 & $<<$ & 2,74 & 0,07 & 0,14 & 0,02 & 0,01 & 0,06 & 0,48 & 100,52 \\
\hline IE04(2,4-2,6m) & 82,30 & 8,00 & 0,08 & 0,72 & 0,78 & 1,37 & 3,30 & 0,44 & 0,08 & 0,02 & 2,66 & 0,08 & 0,14 & 0,01 & 0,02 & 0,06 & 0,65 & 100,71 \\
\hline $\operatorname{IE04}(2,6-2,8 \mathrm{~m})$ & 82,30 & 8,12 & 0,07 & 0,63 & 0,69 & 1,38 & 3,55 & 0,40 & 0,06 & $<<$ & 2,54 & 0,06 & 0,14 & 0,02 & 0,02 & 0,06 & 0,72 & 100,76 \\
\hline $\operatorname{IE04}(2,8-3,0 \mathrm{~m})$ & 81,10 & 8,48 & 0,08 & 0,83 & 0,88 & 1,39 & 3,28 & 0,60 & 0,08 & $<<$ & 3,01 & 0,05 & 0,13 & 0,02 & 0,02 & 0,05 & 0,68 & 100,68 \\
\hline IE05 (0-0,20m) & 75,90 & 10,20 & 0,11 & 1,38 & 1,39 & 1,38 & 3,07 & 1,29 & 0,15 & 0,02 & 4,86 & 0,05 & 0,12 & 0,01 & 0,01 & 0,08 & 0,42 & 100,44 \\
\hline IE05 $(0,20-0,40 \mathrm{~m})$ & 82,60 & 8,13 & 0,05 & 0,43 & 0,63 & 1,51 & 3,97 & 0,29 & 0,07 & $\mathrm{Nd}$ & 2,00 & 0,06 & 0,18 & $<<$ & 0,01 & 0,08 & 0,47 & 100,48 \\
\hline IE05 $(0,40-0,65 \mathrm{~m})$ & 82,90 & 7,59 & 0,07 & 0,51 & 0,68 & 1,50 & 3,24 & 0,46 & 0,06 & $\mathrm{Nd}$ & 2,67 & 0,07 & 0,12 & 0,01 & 0,01 & 0,06 & 0,51 & 100,46 \\
\hline IE06 (0-0,20m) & 80,80 & 7,90 & 0,07 & 0,79 & 0,93 & 1,34 & 3,02 & 0,93 & 0,08 & $<<$ & 3,89 & 0,06 & 0,13 & 0,01 & 0,01 & 0,06 & 0,34 & 100,36 \\
\hline IE06 $(0,20-0,40 m)$ & 83,40 & 7,66 & 0,06 & 0,51 & 0,64 & 1,46 & 3,51 & 0,31 & 0,05 & Nd & 2,15 & 0,06 & 0,12 & 0,01 & 0,01 & 0,06 & 0,36 & 100,37 \\
\hline IE06 $(0,40-0,55 \mathrm{~m})$ & 84,80 & 6,71 & 0,04 & 0,41 & 0,63 & 1,41 & 2,94 & 0,27 & 0,05 & Nd & 2,38 & 0,11 & 0,12 & 0,01 & 0,01 & 0,05 & 0,74 & 100,68 \\
\hline IE07 (0-0,20m) & 77,70 & 9,60 & 0,06 & 0,83 & 0,85 & 1,57 & 3,28 & 0,77 & 0,11 & 0,03 & 3,03 & 0,05 & 0,12 & 0,01 & 0,01 & 0,07 & 1,89 & 99,98 \\
\hline IE07 $(0,20-0,40 \mathrm{~m})$ & 81,90 & 8,40 & 0,04 & 0,40 & 0,53 & 1,59 & 3,53 & 0,29 & 0,06 & $<<$ & 1,81 & 0,07 & 0,14 & 0,01 & 0,01 & 0,06 & 1,13 & 99,97 \\
\hline IE07 $(0,40-0,50 \mathrm{~m})$ & 82,10 & 8,43 & 0,03 & 0,41 & 0,53 & 1,51 & 3,47 & 0,30 & 0,06 & Nd & 1,84 & 0,06 & 0,11 & 0,01 & 0,01 & 0,05 & 1,04 & 99,96 \\
\hline IE08 (0-0,20m) & 81,30 & 7,53 & 0,06 & 0,68 & 0,83 & 1,42 & 2,89 & 0,75 & 0,08 & $<<$ & 2,99 & 0,07 & 0,14 & 0,01 & 0,01 & 0,07 & 1,14 & 99,97 \\
\hline IE08 $(0,20-0,40 \mathrm{~m})$ & 83,40 & 7,55 & 0,03 & 0,36 & 0,56 & 1,61 & 3,09 & 0,31 & 0,06 & $<<$ & 1,88 & 0,07 & 0,09 & 0,01 & $<<$ & 0,05 & 0,89 & 99,96 \\
\hline
\end{tabular}




\begin{tabular}{|c|c|c|c|c|c|c|c|c|c|c|c|c|c|c|c|c|c|c|}
\hline IE08NE08 (0-0,20m) & 77,70 & 9,53 & 0,09 & 0,93 & 0,94 & 1,61 & 3,09 & 0,69 & 0,09 & $<<$ & 3,23 & 0,08 & 0,09 & 0,01 & 0,01 & 0,06 & 1,82 & 99,97 \\
\hline IE08NE08 $(0,20-0,40 \mathrm{~m})$ & 74,20 & 10,90 & 0,09 & 1,29 & 3,38 & 1,71 & 3,38 & 1,02 & 0,13 & 0,03 & 3,62 & 0,04 & 0,12 & 0,01 & 0,02 & 0,06 & 2,21 & 102,21 \\
\hline IE08NE08 $(0,40-0,60 \mathrm{~m})$ & 74,90 & 10,90 & 0,09 & 1,18 & 1,16 & 1,73 & 3,41 & 0,98 & 0,13 & 0,02 & 3,56 & 0,05 & 0,12 & 0,01 & 0,01 & 0,06 & 1,72 & 100,03 \\
\hline IE08NE08 $(0,60-0,70 \mathrm{~m})$ & 76,20 & 10,10 & 0,09 & 1,16 & 1,08 & 1,68 & 3,28 & 0,83 & 0,10 & $<<$ & 3,27 & 0,04 & 0,10 & 0,01 & 0,01 & 0,06 & 2,04 & 100,05 \\
\hline IE09 $(0-0,20 \mathrm{~m})$ & 77,40 & 6,99 & 0,11 & 0,64 & 0,99 & 1,17 & 2,64 & 2,06 & 0,10 & 0,02 & 6,44 & 0,11 & 0,08 & 0,01 & 0,02 & 0,08 & 1,18 & 100,04 \\
\hline ESB01 A $(0-0,20 m)$ & 82,50 & 7,39 & 0,05 & 0,66 & 0,65 & 1,31 & 2,75 & 0,56 & 0,08 & $<<$ & 2,51 & 0,06 & 0,12 & $<<$ & $<<$ & 0,06 & 1,28 & 99,98 \\
\hline ESB01 A $(0,20-0,40 m)$ & 84,30 & 6,93 & 0,04 & 0,25 & 0,49 & 1,23 & 3,49 & 0,22 & 0,07 & $<<$ & 1,95 & 0,11 & 0,10 & $\mathrm{Nd}$ & $<<$ & 0,06 & 0,78 & 100,02 \\
\hline ESB01 A $(0,40-0,60 m)$ & 84,80 & 6,72 & 0,03 & 0,25 & 0,41 & 1,22 & 3,50 & 0,18 & 0,06 & $\mathrm{Nd}$ & 1,97 & 0,11 & 0,09 & $<<$ & $\mathrm{Nd}$ & 0,06 & 0,61 & 100,01 \\
\hline ESB01 A $(0,60-0,80 \mathrm{~m})$ & 85,80 & 6,15 & 0,03 & 0,25 & 0,34 & 1,19 & 3,28 & 0,15 & 0,06 & $\mathrm{Nd}$ & 1,78 & 0,11 & 0,10 & $<<$ & $\mathrm{Nd}$ & 0,06 & 0,69 & 99,99 \\
\hline ESB01 B (0-0,20m) & 80,20 & 8,61 & 0,05 & 0,68 & 0,70 & 1,44 & 3,63 & $\overline{0,46}$ & 0,09 & $<<$ & 2,44 & 0,09 & 0,12 & 0,01 & 0,01 & 0,07 & 1,42 & 100,02 \\
\hline ESB01 B $(0,20-0,40 m)$ & 84,80 & 6,66 & $<<$ & 0,27 & 0,45 & 1,22 & 3,28 & 0,22 & $\mathbf{0 , 0 7}$ & Nd & 1,99 & 0,09 & $\mathbf{0 , 1 0}$ & $<<$ & $<<$ & 0,06 & 0,79 & 100,00 \\
\hline ESB01 B $(0,40-0,60 m)$ & 85,20 & 6,45 & 0,02 & 0,29 & 0,46 & 1,21 & 3,35 & 0,15 & 0,06 & Nd & 1,82 & 0,10 & 0,10 & $<<$ & Nd & 0,06 & 0,72 & 99,99 \\
\hline ESB01 C (0-0,20m) & 84,10 & 7,12 & 0,03 & 0,28 & 0,45 & 1,31 & 3,34 & 0,26 & 0,07 & $\mathrm{Nd}$ & 2,01 & 0,09 & 0,12 & $<<$ & $\mathrm{Nd}$ & 0,05 & 0,74 & 99,97 \\
\hline ESB01 C $(0,20-0,40 m)$ & 85,50 & 6,41 & 0,02 & 0,19 & 0,35 & 1,24 & 3,43 & 0,16 & 0,05 & $\mathrm{Nd}$ & 1,68 & 0,11 & 0,12 & $<<$ & $\mathrm{Nd}$ & 0,06 & 0,73 & 100,05 \\
\hline ESB01 C $(0,40-0,60 m)$ & 85,40 & 6,47 & 0,03 & 0,14 & 0,36 & 1,20 & 3,41 & 0,12 & 0,05 & $\mathrm{Nd}$ & 1,77 & 0,12 & 0,12 & $\mathrm{Nd}$ & $\mathrm{Nd}$ & 0,06 & 0,78 & 100,03 \\
\hline ESB01 C $(0,60-0,80 \mathrm{~m})$ & 85,60 & 6,46 & 0,03 & 0,24 & 0,41 & 1,31 & 3,22 & 0,16 & 0,04 & $\mathrm{Nd}$ & 1,65 & 0,08 & 0,11 & $\mathrm{Nd}$ & $\mathrm{Nd}$ & 0,05 & 0,68 & 100,04 \\
\hline ESB02 A (0-0,20m) & 80,60 & 7,68 & 0,10 & 0,72 & 0,84 & 1,42 & 3,26 & 0,73 & 0,07 & Nd & 3,05 & 0,07 & 0,11 & 0,01 & 0,01 & 0,06 & 1,28 & 100,01 \\
\hline ESB02 A $(0,20-0,40 m)$ & 79,20 & 8,41 & 0,09 & 0,84 & 0,85 & 1,50 & 3,26 & 0,79 & 0,09 & $<<$ & 3,35 & 0,08 & $\mathbf{0 , 1 1}$ & 0,02 & 0,01 & 0,06 & 1,34 & 100,00 \\
\hline ESB02 B $(0-0,20 m)$ & 76,50 & 8,95 & 0,11 & 0,93 & 0,97 & 1,49 & 3,67 & 1,40 & 0,11 & $<<$ & 4,40 & 0,05 & 0,14 & 0,02 & 0,02 & 1,11 & 1,13 & 101,00 \\
\hline ESB02 B $(0,20-0,40 m)$ & 77,90 & 8,89 & 0,07 & 0,88 & 0,89 & 1,47 & 3,68 & 1,06 & 0,10 & 0,02 & 3,59 & 0,04 & 0,15 & 0,01 & 0,02 & 0,06 & 1,13 & 99,96 \\
\hline ESB02 B $(0,40-0,60 \mathrm{~m})$ & 77,40 & 8,62 & 0,08 & 0,84 & 0,91 & 1,48 & 3,51 & 0,96 & 0,09 & 0,04 & 3,46 & 0,06 & 0,13 & 0,02 & 0,01 & 0,07 & 2,32 & 100,00 \\
\hline ESB03 A $(0-0,20 m)$ & 76,70 & 8,93 & 0,05 & 0,94 & 0,96 & 1,41 & 3,55 & 1,15 & 0,12 & 0,02 & 3,98 & 0,05 & 0,12 & 0,01 & 0,01 & 0,08 & 1,88 & 99,96 \\
\hline ESB03 A $(0,20-0,40 m)$ & 78,40 & 8,81 & 0,05 & 0,82 & 0,86 & 1,43 & 3,55 & 0,89 & 0,12 & $<<$ & 3,39 & 0,06 & 0,14 & 0,01 & $<<$ & $\mathbf{0 , 1 0}$ & 1,33 & 99,96 \\
\hline ESB03 A $(0,40-0,60 m)$ & 78,70 & $\mathbf{8 , 8 0}$ & 0,04 & 0,80 & 0,86 & 1,42 & 3,73 & 0,76 & 0,12 & $<<$ & 3,12 & 0,06 & 0,13 & $\mathbf{0 , 0 1}$ & $<<$ & 0,07 & 1,39 & 100,01 \\
\hline ESB03 A $(0,60-0,70 m)$ & 81,50 & 8,28 & 0,02 & 0,70 & 0,64 & 1,30 & 3,38 & 0,53 & 0,11 & 0,02 & 2,36 & $\mathbf{0 , 0 7}$ & 0,12 & $<<$ & $<<$ & 0,06 & 0,91 & 100,00 \\
\hline ESB03 A $(0,60-0,70 \mathrm{~m})$ & 81,76 & 7,64 & 0,05 & 0,55 & 0,64 & 1,34 & 3,41 & 0,55 & 0,08 & 0,03 & 2,61 & 0,08 & $\mathbf{0 , 1 2}$ & $\mathbf{0 , 0 1}$ & 0,01 & 0,12 & 1,10 & 100,05 \\
\hline Ju $(0-0,15 \mathrm{~m})$ & 81,10 & 8,13 & 0,06 & 0,33 & 0,47 & 0,65 & 3,08 & 0,35 & 0,10 & 0,01 & 3,04 & 0,08 & 0,10 & 0,01 & $\mathrm{Nd}$ & 0,06 & 2,41 & 99,98 \\
\hline $\mathrm{Ju}(0,15-0,30 \mathrm{~m})$ & 82,80 & 7,76 & 0,05 & 0,22 & 0,40 & 0,68 & 2,87 & 0,28 & 0,07 & 0,01 & 2,07 & 0,08 & 0,09 & $<<$ & $\mathrm{Nd}$ & 0,05 & 2,60 & 100,03 \\
\hline $\mathrm{Ju}(0,30-0,45 \mathrm{~m})$ & 83,70 & 7,62 & 0,07 & 0,18 & 0,36 & 0,68 & 2,93 & 0,17 & 0,08 & 0,01 & 2,24 & 0,10 & 0,09 & $<<$ & $\mathrm{Nd}$ & 0,05 & 1,78 & 100,06 \\
\hline $\mathrm{Ju}(0,45-0,60 \mathrm{~m})$ & 81,60 & 8,61 & 0,06 & 0,32 & 0,48 & 0,71 & 3,22 & 0,28 & 0,10 & 0,01 & 2,80 & 0,06 & 0,10 & 0,01 & $\mathrm{Nd}$ & 0,05 & 1,58 & 99,99 \\
\hline Média & 80,96 & 8,13 & $\mathbf{0 , 0 7}$ & 0,68 & $\mathbf{0 , 8 1}$ & 1,35 & 3,27 & 0,64 & 0,08 & 0,02 & 3,02 & $\mathbf{0 , 0 7}$ & 0,12 & $\mathbf{0 , 0 1}$ & 0,01 & 0,08 & & \\
\hline
\end{tabular}

